VILNIAUS GEDIMINO TECHNIKOS UNIVERSITETAS

Rimvydas MOCEIKIS

\title{
DISPERSIŠKAI ARMUOTO APDAILINIO BETONO TECHNOLOGINIŲ IR EKSPLOATACINIŲ SAVYBIŲ TYRIMAI
}

DAKTARO DISERTACIJA

TECHNOLOGIJOS MOKSLAI, MEDŽIAGŲ INŽINERIJA (T 008)

Vilnius, 2021 
Disertacija rengta 2016-2021 metais Vilniaus Gedimino technikos universitete. Vadovas

doc. dr. Asta KIČAITÉ (Vilniaus Gedimino technikos universitetas, medžiagų inžinerija - T 008).

Vilniaus Gedimino technikos universiteto Medžiagų inžinerijos mokslo krypties disertacijos gynimo taryba:

\section{Pirmininkas}

dr. Valentin ANTONOVIČ (Vilniaus Gedimino technikos universitetas, medžiagu inžinerija - T 008).

\section{Nariai:}

prof. dr. Mindaugas DAUKŠYS (Kauno technologijos universitetas, statybos inžinerija - T 002),

doc. dr. Karel DVORAK (Brno technologijos universitetas, Čekija, medžiagu inžinerija - T 008),

dr. Modestas KLIGYS (Vilniaus Gedimino technikos universitetas, medžiagu inžinerija - T 008),

prof. dr. Juozas VALIVONIS (Vilniaus Gedimino technikos universitetas, statybos inžinerija - T 002).

Disertacija bus ginama viešame Medžiagų inžinerijos mokslo krypties disertacijos gynimo tarybos posèdyje $\mathbf{2 0 2 1} \mathrm{m}$. liepos 9 d. 9 val. Vilniaus Gedimino technikos universiteto senato posèdžių salëje.

Adresas: Sauletekio al. 11, LT-10223 Vilnius, Lietuva.

Tel.: (8 5) 274 4956; faksas (8 5) 270 0112; el. paštas doktor@vilniustech.lt

Pranešimai apie numatomą ginti disertaciją išsiųsti $2021 \mathrm{~m}$. birželio $8 \mathrm{~d}$.

Disertaciją galima peržiūrèti Vilniaus Gedimino Technikos universiteto talpykloje http://dspace.vgtu.lt ir Vilniaus Gedimino technikos universiteto bibliotekoje (Saulètekio al. 14, LT-10223 Vilnius, Lietuva).

Vilniaus Gedimino technikos universiteto 2021-032-M mokslo literatūros knyga doi: 10.20334/2021-032-M

(C) Vilniaus Gedimino technikos universitetas, 2021

(C) Rimvydas Moceikis, 2021

rimvydas.moceikis@vilniustech.lt 
VILNIUS GEDIMINAS TECHNICAL UNIVERSITY

Rimvydas MOCEIKIS

\section{INVESTIGATION OF TECHNOLOGICAL AND PERFORMANCE CHARACTERISTICS OF DECORATIVE CONCRETE WITH DISPERSE REINFORCEMENT}

DOCTORAL DISSERTATION

TECHNOLOGICAL SCIENCES,

MATERIALS ENGINEERING (T 008)

Vilnius, 2021 
Doctoral dissertation was prepared at Vilnius Gediminas Technical University in 2016-2021.

\section{Supervisor}

Assoc. Prof. Dr Asta KIČAITĖ (Vilnius Gediminas Technical University, Materials Engineering - T 008).

The Dissertation Defence Council of Scientific Field of Materials Engineering of Vilnius Gediminas Technical University:

\section{Chairman}

Dr Valentin ANTONOVIČ (Vilnius Gediminas Technical University, Materials Engineering - T 008).

\section{Members:}

Prof. Dr Mindaugas DAUKŠYS (Kaunas University of Technology, Civil Engineering - T 002),

Assoc. Prof. Dr Karel DVORAK (Brno University of Technology, Czech Republic, Materials Engineering -T 008),

Dr Modestas KLIGYS (Vilnius Gediminas Technical University, Materials Engineering - T 008),

Prof. Dr Juozas VALIVONIS (Vilnius Gediminas Technical University, Civil Engineering - T 002).

The dissertation will be defended at the public meeting of the Dissertation Defence Council of Materials Engineering in the Senate Hall of Vilnius Gediminas Technical University at 9 a. m. on 9 July 2021.

Address: Saulètekio al. 11, LT-10223 Vilnius, Lithuania.

Tel.: +370 5274 4956; fax +370 5270 0112; e-mail: doktor@vilniustech.lt

A notification on the intend defending of the dissertation was send on 8 June 2021. A copy of the doctoral dissertation is available for review at Vilnius Gediminas Technical University repository http://dspace.vgtu.lt and at the Library of Vilnius Gediminas Technical University (Sauletekio al. 14, LT-10223 Vilnius, Lithuania). 


\section{Reziumè}

Disertacijoje nagrinèjamos dispersiškai armuotų smulkiagrūdžių apdailinių betonų (DASAB) su skirtingais užpildais (kvarciniu smèliu, granito atsijomis bei vietinių karjerų ịprastiniu smėliu), plaušais (stiklo, bazalto, anglies, polivinilo alkoholio) bei mineraliniais priedais $\left(\mathrm{SiO}_{2}\right.$ mikrodulkèmis (SD) ir metakaolinu (MK)) savybès. Šio darbo tikslas yra sukurti dispersiškai armuotą betoną surenkamujų sieninių elementų gamybai ir ištirti plaušų, užpildų bei aktyvių mineralinių priedų poveiki mišinių konsistencijai bei segregacijai ir betono apdailinio paviršiaus eksploatacinèms savybèms.

Disertaciją sudaro įvadas, trys skyriai, bendrosios išvados, naudotos literatūros ir autoriaus publikacijų disertacijos tema sąrašai, santrauka anglų kalba bei septyni priedai.

Pirmasis skyrius skirtas literatūros analizei. Jame pateikiama informacija apie DASAB gamybos technologijas bei jų raidą, skirtingų plaušų įtaką betono mišinio ir sukietejusio betono fizikinèms ir mechaninèms savybèms. Taip pat analizuojamas šių kompozitų eksploatacinių savybių pastovumas, ịvairių įmaišų bei priedų poveikis ilgaamžiškumui. Skyriaus pabaigoje formuluojamos išvados ir tikslinami disertacijos uždaviniai.

Antrajame skyriuje aprašytos tiriamajame darbe panaudotos medžiagos bei jų savybès. Pateiktos tyrinètų betono mišinių sudètys, aprašytas pasirinktas betono maišymo procesas ir bandinių formavimas. Aptariami tyrimo metodai bei naudota laboratorine įranga.

Trečiajame skyriuje aprašyti DASAB kompozito technologinių, mechaninių savybių bei ilgaamžiškumo tyrimai. Pateikiami duomenys apie plaušų bei trupintų uolienų užpildų poveikị betono mišinio konsistencijai ir segregacijai, taip pat atsparumo šalčiui tyrimų duomenys su cementinę matricą modifikuojančiais MK ir SD priedais. Panaudojus tyrimų rezultatus, sukurtas dispersiškai armuotas betono kompozitas, kurio lenkimo stipris - 10,1 MPa, lenkimo deformacijų energija $1149 \mathrm{~N} / \mathrm{m}$ ir kuris gali būti panaudotas fasadų konstrukcijoms, eksploatuojamoms ne mažiau kaip 20 metų agresyviomis Baltijos regiono klimato sąlygomis, kurioms būdingas užšaldymo ir atšildymo ciklų poveikis.

Disertacijos tema atspausdinti 7 moksliniai straipsniai: trys - recenzuojamuose mokslo žurnaluose, du - recenzuojamoje tarptautinių konferencijų medžiagoje įtrauktoje ị Clarivate Analytics Web of Science ir du kitų tarptautinių konferencijų duomenų bazių leidiniuose. Disertacijos tema pristatyti septyni pranešimai Lietuvos ir kitų šalių mokslinèse konferencijose. 


\section{Abstract}

The dissertation deals with properties of dispersive reinforced fine-grained finishing concretes (DASAB) with different aggregates (quartz sand, crushed granite, and conventional quarry sand), fibers (glass, basalt, carbon, polyvinyl alcohol) and mineral additives $\left(\mathrm{SiO}_{2}\right.$ micro fume and metakaolin $\left.(\mathrm{MK})\right)$. The aim of this work is to develop dispersive reinforced concrete for production of prefabricated wall elements and to investigate the effect of fibers, aggregates and active mineral additives on the consistency and segregation of mixtures and the durability of the concrete surface.

The dissertation consists of an introduction, three chapters, general conclusions, used literature and lists of the author's publications on the topic of the dissertation, a summary in English and seven appendices.

The first chapter is devoted to the analysis of the literature. It provides information on DASAB production technologies and their development, the influence of different fibers on the physical and mechanical properties of concrete mix and hardened concrete. The durability mechanisms of these composites and the effect of various mineral additives on durability are also analyzed. At the end of the chapter, conclusions are formulated and the tasks of the dissertation are specified.

The second chapter describes the materials used in the research and their properties. The compositions of the investigated concrete mixtures are presented, the selected concrete mixing process and sample formation are described. Research methods and used laboratory equipment are discussed.

The third chapter describes the research of technological, mechanical properties and durability of DASAB composite. Data on the effect of fiber and crushed rock aggregates on the workability and segregation of concrete mix, as well as data on frost resistance studies with cement matrix-modifying MK and SD additives are presented. Using the research results, a dispersive reinforced concrete composite with a flexural strength of $10.1 \mathrm{MPa}$ and a flexural strain energy of $1149 \mathrm{~N} / \mathrm{m}$ was developed, which can be used for facade structures operated for at least 20 years in aggressive climatic conditions of the Baltic region, which are characterized by the effects of freezing and thawing cycles.

7 scientific articles were published on the topic of the dissertation: three in the peer-reviewed scientific journals, two in the publications of the Clarivate Analytics Web of Science database in Conference Proceedings, and two in the other conference proceedings. Seven papers on the topic of the dissertation were presented at scientific conferences in Lithuania and other countries. 


\section{Žymèjimai}

\section{Simboliai}

$A_{0}-$ bandymų mašinos atliekamas darbas, $\mathrm{Nm}$;

$A$ - deformacijas sukeliančios jègos atliktas darbas, $\mathrm{Nm}$;

$A_{\text {lig }}$ - plyšio plotas (bandinio skerspjūvio plotas), $\mathrm{mm}^{2}$;

$D_{1}-$ didžiausias pasklidusio mišinio skersmuo, $\mathrm{cm}$;

$D_{2}$ - vidinis pasklidusio mišinio skersmuo, $\mathrm{cm}$;

$d_{l}-$ užpildo dalelès ilgoji kraštinè, mm;

$d_{2}$ - užpildo dalelès trumpoji kraštinè, mm;

$d_{\max }$ - užpildo dalelių didžiausias matmuo, mm;

$F$ - deformacijas sukelianti jèga, N;

$G_{f}-$ lenkimo deformacijų energija, N/m;

$h$ - betono mišinio suslūgimas (Sutardo viskozimetro aukštis), cm;

$I$ - užpildo pailgumo indeksas;

$S$ - bandinio ịlinkis (poslinkis);

$W$ - konsistencijos rodiklis, cm;

$x$ - užpildo kiekis, \%.

\section{Santrumpos}

AP - anglies plaušas; 
AR - stiklas - šarmams atsparus stiklo plaušas;

$\mathrm{BP}$ - bazalto plaušas;

CSH - kalcio hidrosilikatai;

DASAB - dispersiškai armuotas smulkiagrūdis apdailinis betonas;

FCM - virtualaus plyšio modelis;

MK - metakaolinas;

PVA - polivinilo alkoholio polimerų plaušas;

$\mathrm{SD}-\mathrm{SiO}_{2}$ mikrodulkès;

S.I.C. - plaušo cementinèje matricoje bandymo metodas;

SPAB - stiklo plaušu armuotas smulkiagrūdis apdailinis betonas;

$\mathrm{SP}$ - stiklo plaušas;

$\mathrm{V} / \mathrm{C}$ - vandens ir cemento masių santykis.

\section{Sąvokos}

Apdailinis betonas - tai betono paviršius su dekoratyvine funkcija, kuriam nèra atliekama jokia papildoma apdaila.

Plaušu armuotas smulkiagrūdis betonas - tai kompozitas, kurį sudaro cementinė matrica su smulkiu užpildu (iki $2 \mathrm{~mm}$ frakcijos) bei armuojantis plaušas (stiklo, bazalto, anglies arba PVA polimerų).

Plaušas - tai trumpi elementai (fibros), kurie gaunami automatizuotai karpant ištisinị pluoštą (stiklo, bazalto ar anglies).

Dispersinis armavimas - tai armavimo būdas, kai ị betono mišinị yra įmaišomi trumpi armuojantys elementai (plaušai, fibros).

Intensyvaus maišymo metodas - tai betono mišinio ruošimo būdas, kai naudojamas spiralinès formos maišytuvas, besisukantis aplink savo ašį 1000 aps./min greičiu.

Takus betono mišinys - tai mišinys, kuriam nereikalingas išorinis ar vidinis vibravimas, kad pasklistų formoje.

Standus betono mišinys - tai netakus betono mišinys, kuris sklinda tik intensyviai tankinant.

Mišinio konsistencija - tai betono mišinio technologinis rodiklis, apibūdinantis mišinio tinkamumą tam tikram gamybos (formavimo) būdui, kuris nusakomas dviem parametrais - mišinio pasklidimo ir suslūgimo.

Mišinio pasklidimas - tai betono mišinio technologinis parametras, apibūdinamas kaip didžiausias pasklidusio mišinio skersmuo.

Mišinio suslūgimas - tai betono mišinio technologinis parametras, apibūdinamas kaip aukščių skirtumas tarp pasklidusio mišinio paviršiaus ir bandymų cilindro (Sutardo viskozimetro) aukščio.

Mišinio segregacija - dalelių išsiskirstymas mišinyje dèl jų dydžio, tankio, formos ar kitų skirtingų savybių. 
Segregacijos rodiklis - tai betono mišinio segregacijos lygi ịvertinantis dydis.

Užpildo dalelių pailgumo indeksas - užpildo dalelès formos parametras, ilgesnès kraštinès santykis su trumpesniaja.

Plastinès lenkimo deformacijos - deformacijos, kurios vyksta toliau atsivèrus plyšiams ir pasiekus maksimalų stiprumą.

Liekamasis stipris - bandinio lenkimo stipris prie labai didelių deformacijų (arti suirimo).

Lenkimo deformacijų energija - energijos kiekis, reikalingas pilnai suardyti bandinị.

Cikliškas užšaldymas ir atšildymas - betono struktūrą ardantis procesas, kurio metu įmirkęs bandinys yra cikliškai užšaldomas ir atšildomas kintant temperatūrai nuo $+20{ }^{\circ} \mathrm{C}$ iki $-20{ }^{\circ} \mathrm{C}$.

Paviršiniai masės nuostoliai - tai atskilę betono paviršiaus struktūros elementai dèl užšaldymo ir atšildymo ciklų poveikio.

Plaušo - matricos kontaktinė zona - tai zona tarp plaušo paviršiaus ir cementinio akmens, kuri užtikrina dviejų skirtingų medžiagų tarpusavio sukibimą.

Statinis nuovargis - laipsniškas $\mathrm{SiO}_{2}$ ryšių trūkinėjimas ties stiklo plaušelio paviršiuje esančio plyšio viršūne veikiant statinei apkrovai. 



\section{Turinys}

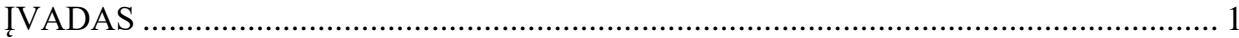

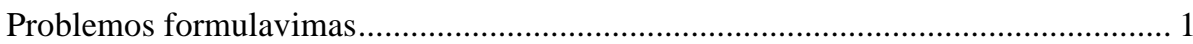

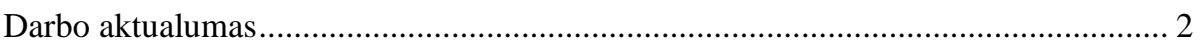

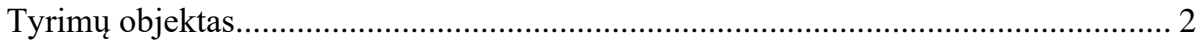

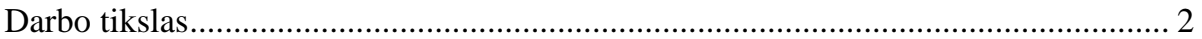

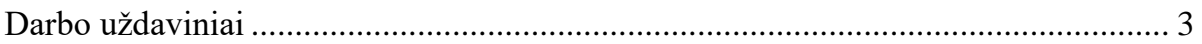

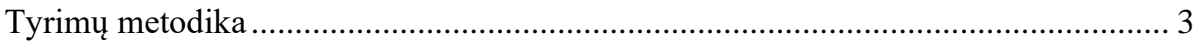

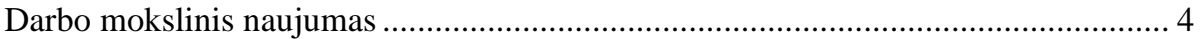

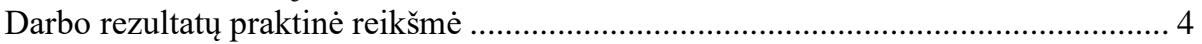

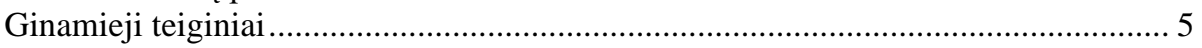

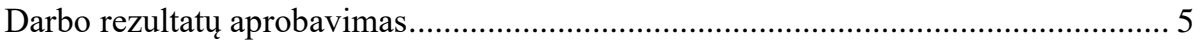

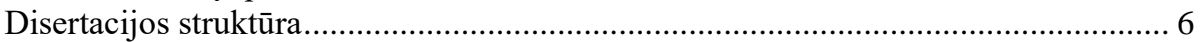

1. DISPERSIŠKAI ARMUOTŲ SMULKIAGRŪDŽIŲ BETONŲ TECHNOLOGINIŲ IR EKSPLOATACINIŲ SAVYBIŲ TYRIMŲ APŽVALGA …………………......... 7

1.1. Dispersiškai armuotų betonų gamybos raida ....................................................... 7

1.2. Dispersiškai armuotų betonų gamybos technologija ........................................... 11

1.3. Dispersiškai armuotų smulkiagrūdžių betonų savybių apžvalga ......................... 13

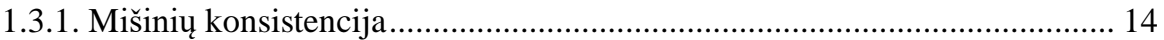

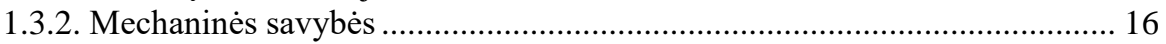

1.4. Skirtingų betono komponentų charakteristikos ir panaudojimas ........................ 18

1.5. Plaušu armuoto smulkiagrūdžio betono ilgaamžiškumas .................................... 23 
1.5.1. Mechaninių savybių pastovumo vertinimo principai.................................... 23

1.5.2. Mechaninių savybių pastovumo tyrimo metodai............................................ 25

1.5.3. Stiklo plaušu armuoto betono korozijos procesai .......................................... 28

1.5.4. Korozijos procesų vertinimas pagal betono lenkimo deformacijų

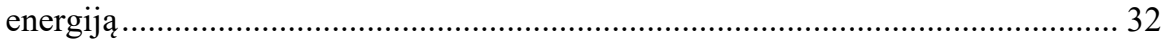

1.6. Pirmojo skyriaus išvados ir disertacijos uždavinių formulavimas...................... 34

2. KOMPOZITUI SUKURTI NAUDOTOS MEDŽIAGOS IR TYRIMO METODAI . 37

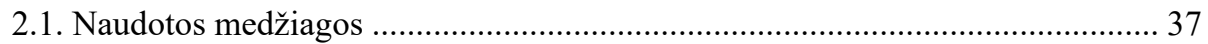

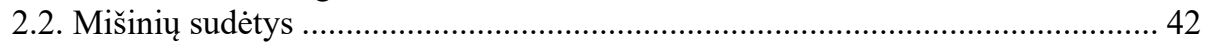

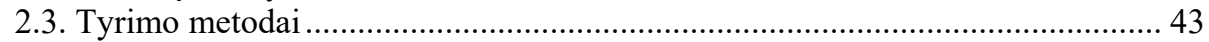

2.3.1. Mišinių ruošimas ir bandinių formavimas .................................................. 43

2.3.2. Mišinių konsistencijos nustatymas ................................................................ 45

2.3.3. Betono mechaninių savybių nustatymas..................................................... 46

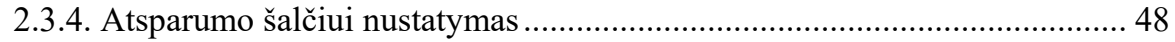

2.3.5. Technologinių ir kitų savybių nustatymas ................................................... 49

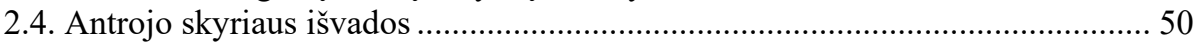

3. MINERALINIAIS PRIEDAIS MODIFIKUOTO APDAILINIO BETONO SU DISPERSINIU ARMAVIMU TECHNOLOGINIŲ IR EKSPLOATACINIŲ

SAVYBIU TYRIMAI ....................................................................................... 51

3.1. Smulkiagrūdžio apdailinio betono su skirtingais plaušais technologinių bei

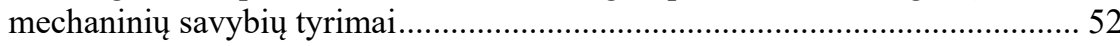

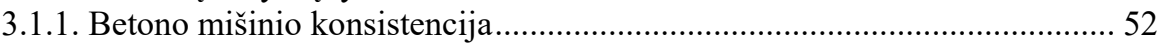

3.1.2. DASAB betono mechaninès savybès ir plaušo parinkimas .......................... 54

3.2. Stiklo plaušu armuotų betonų segregacijos ir konsistencijos tyrimai...................58

3.2.1. Užpildų poveikis stiklo plaušu armuotu mišinių konsistencijai ................... 58

3.2.2. Aktyvių mineralinių priedų poveikis stiklo plaušu armuotų mišinių

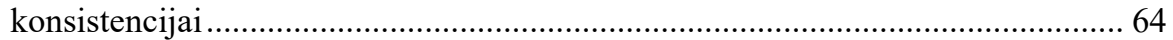

3.3. Stiklo plaušu armuoto betono fizikinių bei mechaninių savybių tyrimai ............ 65

3.4. Stiklo plaušu armuoto betono atsparumas šalčiui............................................. 72

3.4.1. Itraukto oro kiekis betono mišinyje .......................................................... 73

3.4.2. Betono paviršiaus destrukcijos dèl užšaldymo ir atšildymo ciklų

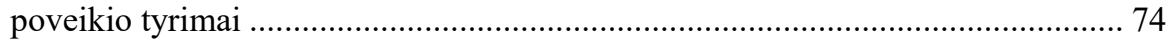

3.4.3. Betono mechaninių savybių bei lenkimo deformacijų energijos pokyčių dèl cikliško užšaldymo ir atšildymo tyrimai .......................................... 78

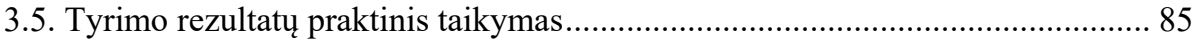

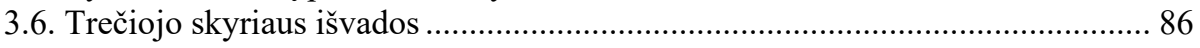

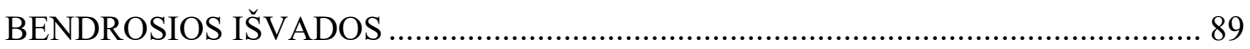

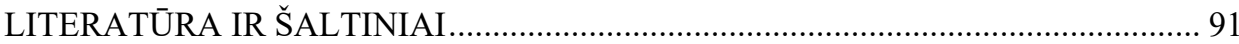


PRIEDAI ${ }^{1}$

A priedas. Portlandcemenčio CEM I 52,5R fizikinès ir mechaninès savybės 121

B priedas. Užpildų pagrindinès fizikinès ir cheminès charakteristikos

$\mathrm{C}$ priedas. Aktyvių mineralinių priedų fizikinès charakteristikos

D priedas. Superplastiklio charakteristikos

E priedas. Betono mišinių sudètys

F priedas. Autoriaus sąžiningumo deklaracija

$\mathrm{G}$ priedas. Bendraautorių sutikimai teikti publikacijose skelbtą medžiagą daktaro disertacijoje.

$\mathrm{H}$ priedas. Autoriaus mokslinių publikacijų disertacijos tema kopijos

${ }^{1}$ Priedai pateikiami pridètoje kompaktineje plokštelèje. 



\section{Contents}

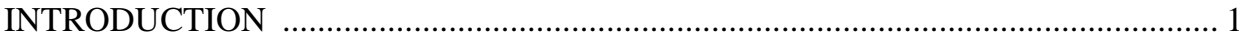

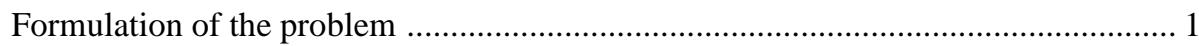

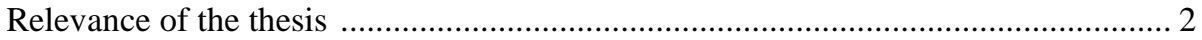

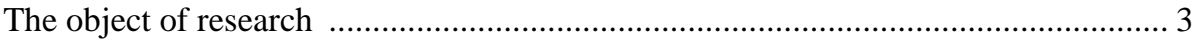

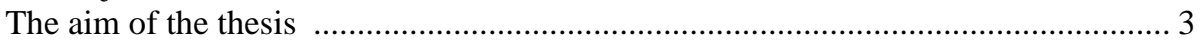

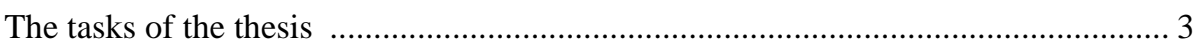

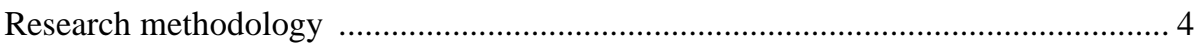

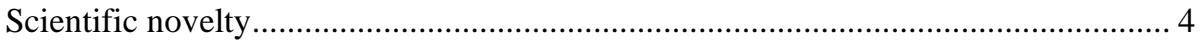

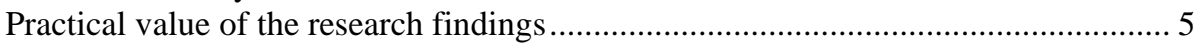

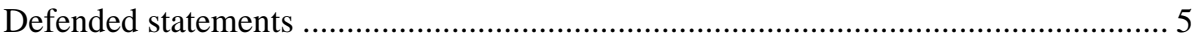

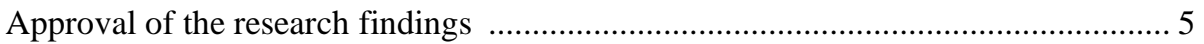

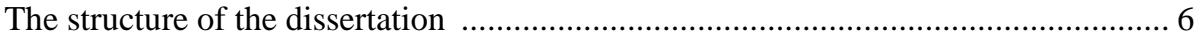

1. RESEARCH ANALYSIS OF TECHNOLOGICAL AND PERFORMANCE CHARACTERISTICS OF DECORATIVE CONCRETE WITH DISPERSE

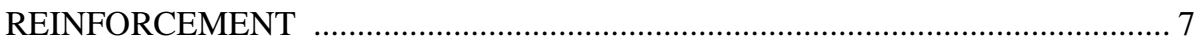

1.1. Brief history of fiber reinforced concrete ………............................................. 7

1.2. Production principles of fiber reinforced concrete ……..................................... 11

1.3. Properties of fine graded fibre reinforced concrete ............................................ 13

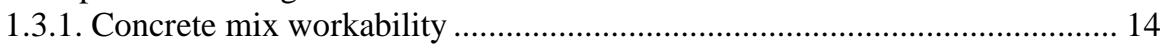

1.3.2. Mechanical properties ............................................................................ 16

1.4. Properties and implementation of different concrete components ..................... 18 
1.5. Durability investigation of fine graded fiber reinfored concrete. ....................... 23

1.5.1. Durability assesement principles of mechanical properties......................... 23

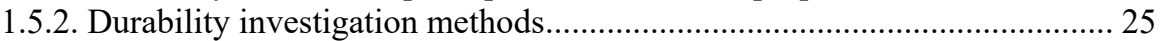

1.5.3. Ageing processes of glass fiber reinforced concrete ………….................... 28

1.5.4. Ageing process asessement by flexural stain energy ................................... 32

1.6. Conclusions of the first chapter and formulation of the objectives of thesis...... 34

2. MATERIALS USED FOR THE COMPOSITE AND RESEARCH METHODS ...... 37

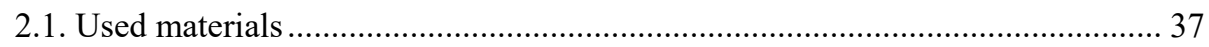

2.2. Concrete compositions ................................................................................. 42

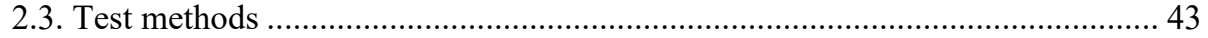

2.3.1. Concrete mix and specimen preparation.................................................... 43

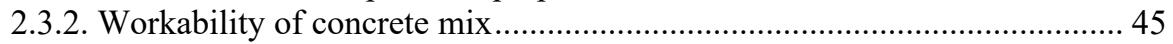

2.3.3. Mechanical characteristics of concrete ..................................................... 46

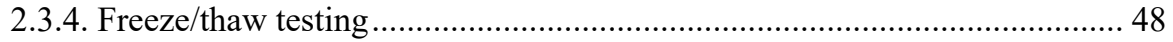

2.3.5. Technological and other properties ......................................................... 49

2.4. Conclusions of the second chapter ................................................................. 50

3. RESEARCH OF TECHNOLOGICAL AND PERFORMANCE

CHARACTERISTICS OF DECORATIVE CONCRETE WITH DISPERSE

REINFORCEMENT MODIFIED BY MINERAL ADDITIVES ............................ 51

3.1. Investigation of technological and mechanical properties of fine-grained decorative concrete with disperse reinforcement............................................. 52

3.1.1. Concrete mix workability ....................................................................... 52

3.1.2. Concrete mechanical properties and fiber selection ..................................... 54

3.2. Investigation of glass fibre reinforced concrete mix workability and

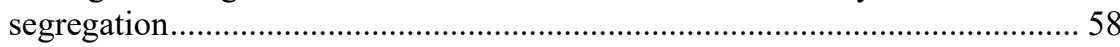

3.2.1. Influence of aggregates on concrete mix workability ................................ 58

3.2.2. Influence of active mineral additives on concrete mix workability............. 64

3.3. Investigation of physical and mechanical properties of glass fiber reinforced

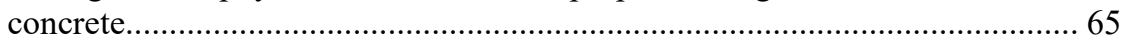

3.4. Resistance to freezing and thawing of glass fiber reinforced concrete............... 72

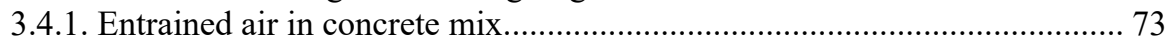

3.4.2. Investigation of the effect of concrete surface destruction due to cyclic freezing and thawing ............................................................................... 74

3.4.3. Investigation of mechanical properties of concrete and flexural strain energy changes due to cyclic freezing and thawing .......................................... 78

3.5. Practical implementation of research findings ……......................................... 85

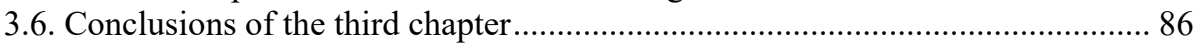

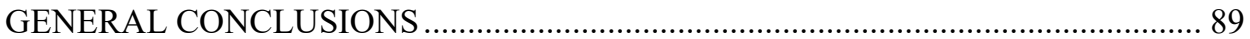

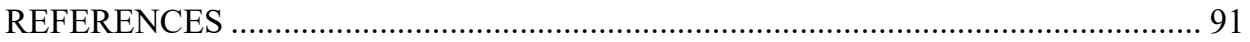


LIST OF SCIENTIFIC PUBLICATIONS BY THE AUTHOR ON THE TOPIC OF THE DISSERTATION

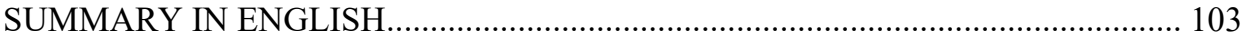

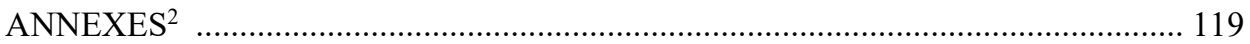

Annex A. Physical and mechanical properties of Portlandcement CEM I 52,5R .. 121

Annex B. Main physical and chemical characteristics of aggregates...................... 122

Annex C. Main physical characteristics of reactive micro fillers ............................ 123

Annex D. Superplasticiser GLENIUM ACE 430 charactristics ............................. 124

Annex E. Concrete mix compositions ............................................................ 125

Annex F. Author's declaration of integrity ............................................................ 127

Annex G The co-authors' agreements for providing the materials of the joint publications in the thesis........................................................................... 128

Annex H. Copies of the scientific publications by the author on the topic

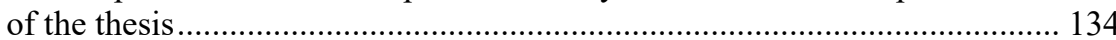

${ }^{2}$ The annexes are supplied in the enclosed compact disc. 



\section{Ivadas}

\section{Problemos formulavimas}

Cementinejje matricoje įmaišius didelio tempimo stiprio ir deformacijų modulio plaušą, trapi medžiaga (betonas) virsta naujo tipo kompozitu, atspariu įvairių dinaminių apkrovų poveikiui. Mokslinèje literatūroje nagrinèjant šių kompozitų mechanines charakteristikas, dažnai apsiribojama tik lenkimo stipriu, kuris nenusako šiai medžiagai būdingų plastinių savybių. Todèl dispersiškai armuotų betono kompozitų mechaniniam atsparumui apibūdinti būtų tikslinga panaudoti lenkimo deformacijų energiją, kuri nusako medžiagos gebejjimą plastiškai deformuotis iki suirimo (bandiniui pasiekus tam tikrą ribinị ịlinki)).

Betono mišinio konsistencija daro įtaką formuojamo gaminio paviršiaus kokybiniams parametrams (struktūrai, faktūrai bei porų kiekiui), taip pat ir cementinès matricos vientisumui bei plaušo pasiskirstymui joje. Todèl būtina ištyrinèti trupintų uolienų užpildų poveikị mišinių konsistencijai bei segregacijai, nustatyti šių parametrų priklausomybes nuo užpildo dalelių formos. Dispersiškai armuoto apdailinio betono kompozito technologiniams parametrams bei eksploatacinèms savybėms pagerinti gali būti naudojami aktyvūs mineraliniai priedai $-\mathrm{SiO}_{2}$ mikrodulkès ir metakaolinas, kurių poveikis kompozito atsparumui užšaldymo ir atšildymo ciklų poveikiui bei lenkimo deformacijų energijai dar nèra ištyrinètas. 


\section{Darbo aktualumas}

Statybų sektoriuje pastaruoju metu sparčiai populiarejja natūralaus betono fasadų apdaila. Nors ši tendencija iš esmès susijusi su architektūros, kaip estetinès išraiškos poveikiu ieškant naujo subtilaus medžiagiškumo, tačiau tai paliečia ir labai svarbius statybinių medžiagų tvarumo klausimus. Per paskutinius dešimtmečius didelị pranašumą ịgijo fasadai iš apdailinio betono, kai sienos yra suprojektuojamos iš surenkamų trisluoksnių arba atskirų vieno sluoksnio apdailinių sieninių elementų. Toks statybos būdas leidžia gerokai sutaupyti darbo jègos, automatizuoti ịvairius technologinius procesus, kuriuos lengviau kontroliuoti ir užtikrinti žymiai geresnę gaminamų sieninių elementų kokybę.

Dispersiškai armuotų betonų taikymas pramoninejje trisluoksnių sieninių elementų gamyboje yra perspektyvi inovacija, kuri itin palengvintų konstrukcijas bei sumažintų sienų storị. Dẻl to sumažètų transportavimo kaštai, laikančiųų sienų, pamatų apkrovos, padidètų vidaus patalpų plotas. Tai pat trumpètų ir gaminio formavimo laikas, nes nebereikètų gaminti armokarkasų. Kadangi gamykliniu būdu sieniniai elementai formuojami horizontalioje padètyje, panaudojus šiame darbe tyrinejjamus takius apdailinio betono mišinius, gaunami aukštos kokybès betono paviršiai.

Kita plati dispersiškai armuotų betonų panaudojimo sritis - liejimo arba purškimo būdu gaminami pakabinami sieniniai elementai ventiliuojamiems fasadams. Lyginant su paplitusiu Hitcheko metodu gaminamomis fibrocementinèmis plokštėmis, būtų galima neapsiriboti vien plokščios formos gaminiais ir panaudojant specialius klojinius išgauti sudètingas formas bei ịvairius paviršiaus reljefus.

\section{Tyrimų objektas}

Tyrimų objektas - dispersiškai armuotas smulkiagrūdis apdailinis betonas su skirtingais užpildais ir cementinès matricos struktūrą modifikuojančiais priedais.

\section{Darbo tikslas}

Šio darbo tikslas yra sukurti dispersiškai armuotą apdailinį betoną surenkamujų sieninių elementu gamybai naudojant skirtingus plaušus, užpildus bei aktyvius mineralinius priedus. 


\section{Darbo uždaviniai}

Darbo tikslui pasiekti darbe reikia spręsti šiuos uždavinius:

1. Parinkti žaliavas ir jų proporcijas apdailinio betono kompozitui surenkamųų sieninių elementų gamyboje, kurios užtikrintų gaminio atsparumą trapiam suirimui ir pleišèjimui.

2. Nustatyti stiklo, bazalto, anglies ir polivinilo alkoholio plaušų poveiki plonasienių gaminių apdailinio betono technologinèms bei mechaninèms savybėms kai betono mišiniai ruošiami intensyvaus maišymo būdu.

3. Nustatyti kvarcinio smèlio, granito atsijų bei ịprastinio žvyro karjerų smèlio užpildų dalelių formos poveikị dispersiškai armuoto smulkiagrūdžio betono konsistencijai bei segregacijai.

4. Nustatyti $\mathrm{SiO}_{2}$ mikrodulkių ir metakaolino mineralinių priedų poveiki dispersiškai armuoto betono atsparumui cikliškam užšaldymui ir atšildymui, vertinant betono apdailinio paviršiaus defektus - atskilusio cementinio akmens kiekị ir lenkimo deformacijų energijos pokyčius, kai numatoma gaminio eksploatavimo trukmè - ne mažiau 20 metų.

5. Ištirti plaušo paviršiaus struktūros pokyčius dẻl užšaldymo ir atšildymo ciklų poveikio, kai cementinè matrica modifikuojama $\mathrm{SiO}_{2}$ mikrodulkių ir metakaolino aktyviais mineraliniais priedais.

\section{Tyrimų metodika}

Užpildų poveikis betono konsistencijai ir segregacijai buvo tiriamas pagal šiame darbe sukurtą metodiką. Aktyvių mineralinių priedų poveikis betono ilgaamžišskumui buvo nustatytas atliekant paviršinio užšaldymo ir atšildymo bandymus pagal šiame darbe sukurtą metodiką, vertinant tiriamo kompozito lenkimo deformacijų energijos pokyčius ir apdailinio paviršiaus defektų plotą. Kitos dispersiškai armuotų betonų savybès buvo nustatytos remiantis standartais LST EN 1170-1, LST EN 1170-4, LST EN 196-1, LST EN 15191, LST EN 13198. Matricos ir plaušo kontakto zonos struktūros pokyčiams tyrinèti buvo naudojamas skenuojantis elektroninis mikroskopas (SEM). 


\section{Darbo mokslinis naujumas}

Disertacinio darbo reikšmè apibūdinama dispersiškai armuotų smulkiagrūdžių apdailinių betonų technologinių savybių bei ilgaamžiškumo įvertinimo bandymo metodikų tobulinimu, taip pat naujų smulkiagrūdžių betono mišinių modifikavimu, panaudojant kompleksinius komponentus bei Baltijos regiono klimato sąlygomis eksploatuojamo betono ir jo sudedamujų dalių (komponentų) parametrų ribinių verčių nustatymu. Rengiant disertaciją gauti šie medžiagų inžinerijos mokslui nauji rezultatai:

1. Paaiškintas trupintų uolienų užpildų poveikis betono mišinių technologinėms savybėms ir nustatyta užpildo daleliu formos ịtaka stiklo plaušu armuoto smulkiagrūdžio betono mišinio konsistencijai ir segregacijai.

2. Paaiškintas $\mathrm{SiO}_{2}$ mikrodulkių ir metakaolino mineralinių priedų poveikio mechanizmas smulkiagrūdžio stiklo plaušu armuoto betono kompozito lenkimo deformacijų energijai veikiant cikliškam užšaldymui ir atšildymui.

3. Nustatytas $\mathrm{SiO}_{2}$ mikrodulkių ir metakaolino mineralinių priedų ir jų kiekio smulkiagrūdžio betono mišinyje poveikis apdailinio betono senejjimo procesams dèl užšaldymo ir atšildymo ciklų poveikio.

\section{Darbo rezultatų praktinè reikšmè}

Sukurtas dispersiškai armuoto betono kompozitas, kuri galima panaudoti trisluoksnių surenkamųjų sieninių elementų gamyboje suploninant apdailinį betono sluoksnị iki $15 \mathrm{~mm}$.

Nustatytas granito atsijų bei ịprastinio žvyro karjerų smėlio poveikis betono technologinèms ir mechaninėms savybėms, kai šiais užpildais pakeičiama iki $50 \%$ kvarcinio smèlio betono mišinyje.

Sukurta stiklo plaušu armuoto betono apdailinio paviršiaus ilgaamžiškumo vertinimo metodika pagal atskilusio paviršiaus plotą ir ištirtas metakaolino bei $\mathrm{SiO}_{2}$ mikrodulkių priedų poveikis paviršiaus destrukcijai. 


\section{Ginamieji teiginiai}

1. Stiklo plaušu armuoto smulkiagrūdžio betono mišinio segregacija mažeja didinant apvalios formos užpildo dalelių kiekị, kurios užtikrina tolygų cementinès matricos ir plaušo pasklidimą.

2. Metakaolino ir $\mathrm{SiO}_{2}$ mikrodulkių aktyvūs mineraliniai priedai padidina stiklo plaušu armuoto smulkiagrūdžio betono kompozito lenkimo deformacijų energiją po užšaldymo ir atšildymo ciklų poveikio.

3. Aktyvūs mineraliniai priedai skirtingai veikia smulkiagrūdžio betono cementinès matricos mikrostruktūrą, nuo kurios priklauso betono ilgaamžiškumas, apibūdinamas kaip apdailinio paviršiaus masès nuostoliai veikiant cikliškam užšaldymui ir atšildymui.

\section{Darbo rezultatų aprobavimas}

Disertacijos tema atspausdinti 7 moksliniai straipsniai: trys - recenzuojamuose mokslo žurnaluose (Moceikis et al. 2018a; Moceikis et al. 2018b; Moceikis et al. 2020), du - recenzuojamoje tarptautinių konferencijų medžiagoje, itrauktoje i Clarivate Analytics Web of Science (Moceikis et al. 2017; Moceikis et al. 2018c) ir du kitu tarptautinių konferencijų duomenų bazių leidiniuose (Moceikis et al. 2019a; Moceikis et al. 2019b;).

Disertacijoje atliktų tyrimų rezultatai paskelbti septyniose mokslinėse konferencijose Lietuvoje ir užsienyje:

- Tarptautinejje 19-toje jaunųų mokslininkų konferencijoje „Juniorstav“ 2017, Brno, Čekijoje;

- 20-toje Lietuvos jaunụjų mokslininkų konferencijoje „Mokslas - Lietuvos ateitis“ $^{\prime} 2017 \mathrm{~m}$. Vilniuje;

- 3-oje tarptautineje konferencijoje „Innovative Materials, Structures and Technologies" 2017 m., Rygoje;

- 4-oje tarptautinèje konferencijoje „World Multidisciplinary Civil Engineering - Architecture - Urban Planning Symposium " 2018 m., Prahoje;

- 13-oje tarptautineje konferencijoje „Modern Building Materials Structures And Techniques" 2019 m., Vilniuje;

- 4-oje tarptautineje konferencijoje „Innovative Materials, Structures and Technologies" 2019 m., Rygoje;

- 28-oje tarptautineje konferencijoje „XXVIII Scientific and Technological Conference of Latvian Concrete Association (LCA)“ 2019 m., Rygoje. 


\section{Disertacijos struktūra}

Disertaciją sudaro įvadas, trys skyriai, bendrosios išvados, naudotų literatūros šaltinių bei autoriaus publikacijų sąrašai, santrauka anglų kalba.

Darbo apimtis yra 121 puslapis, tekste panaudotos 11 numeruotų formulių, 74 paveikslai ir 15 lentelių. Rašant disertaciją buvo panaudoti 128 literatūros šaltiniai. 


\section{1}

\section{Dispersiškai armuotų smulkiagrūdžių betony technologinių ir eksploatacinių savybių tyrimų apžvalga}

Skyriuje nagrinėjami dispersiškai armuoto smulkiagrūdžio apdailinio betono (DASAB) gamybos principai, pasaulinè praktika, panaudojimo problemos. Apžvelgiamos pritaikymo sritys, galiojantys standartai bei ịvairių autorių optimalios sudèties tyrimų rezultatai. Analizuojamos betono savybių pastovumo problemos eksploatuojant gaminius natūraliomis lauko sąlygomis.

Skyriaus tematika paskelbti penki autoriaus straipsniai (Moceikis et al., 2018a, 2018b, 2018c, 2019a, 2019b).

\subsection{Dispersiškai armuotų betonų gamybos raida}

Dispersiškai armuotas betonas - tai kompozitinè medžiaga, sudaryta iš cementinès matricos, kurioje atsitiktine tvarka įvairiomis kryptimis yra pasiskirstęs plaušas (1.1 pav.). Šioje būsenoje tiek cementinè matrica tiek plaušas išlaiko savo 
unikalias fizikines bei chemines charakteristikas, kurioms veikiant kartu gaunamas naujų savybių kompozitas, kurių neịmanoma pasiekti naudojant šias medžiagas atskirai (Bartos et al., 2017). Plaušas užtikrina kompozito atsparumą tempimui, o cementinè matrica veikia kaip tempimo įtempius perduodanti terpè.

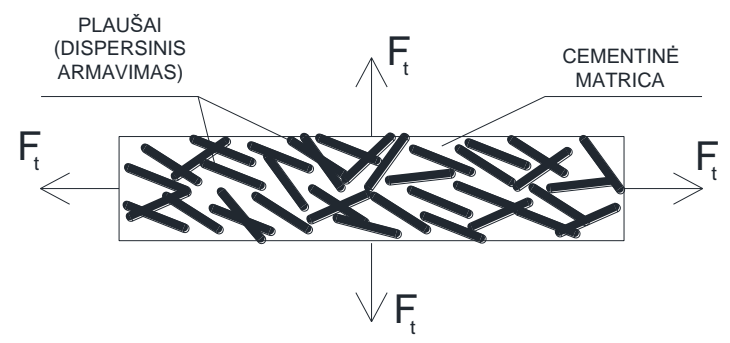

1.1 pav. Dispersinio armavimo schema (sudaryta autoriaus)

Fig. 1.1. Scheme of fiber reinforcement (made by author)

Dispersinio armavimo plaušais poveikis mechaninėms cementinės matricos savybėms pasižymi tuo, kad padidèja matricos smūginis tąsumas bei lenkimo deformacijų energija ir atsparumas tempimo įtempiams. Kitaip sakant, trapi betono matrica tampa plastiška ir energijos kiekis, reikalingas suardyti medžiagai gerokai padidèja (1.2 pav.).

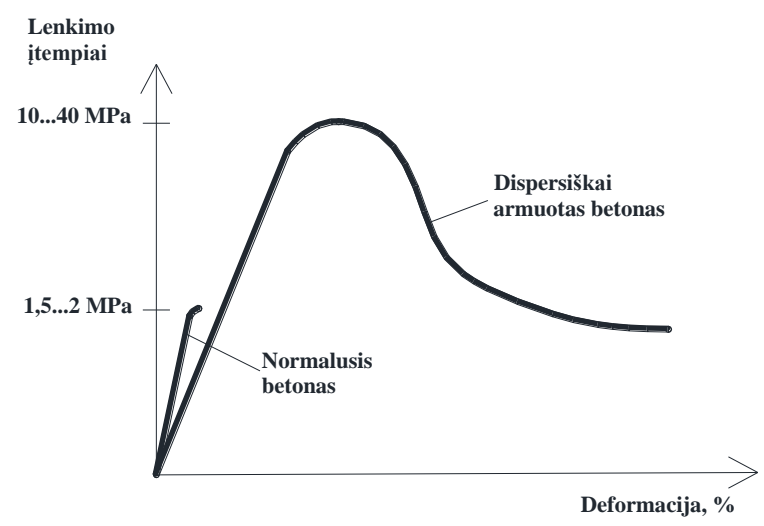

1.2 pav. Dispersinio armavimo įtaka betono lenkimo deformacijų kreivei (sudaryta autoriaus)

Fig. 1.2. Infulence of fiber reinforcement on concrete bending curve (made by author)

Nors armuojančių elementų (plaušų) atsparumas tempimui yra gerokai didesnis nei cementinès matricos (iki 2000 kartų), tačiau fiziškai sudètinga užtikrinti 
armavimo vientisumą per visą elemento ilgị, tempimo jègų veikimo kryptimi (1.3 pav.). Todèl dispersinis armavimas vis dar nèra taikytinas dideles išorines apkrovas perimantiems konstrukciniams elementams (sijoms, kolonoms, perdangų plokštėms) (Gopalaratnam et al., 1995; Akers et al., 2009).

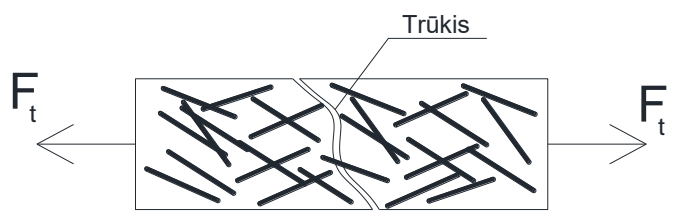

1.3 pav. Cementinès matricos trūkis dèl dispersinio armavimo ne vientisumo (sudaryta autoriaus)

Fig. 1.3. Crack due to non-uniforrmity of fiber reinforcement (made by author)

Dispersinis armavimas plaušais dažniausiai naudojamas plonasieniams apdailiniams fasadų elementams, veikiamiems nedidelių išorinių apkrovų - savojo svorio bei vejjo. İvairių plaušų panaudojimas gali padidinti apdailinio betono ilgaamžiškumą, lyginant su metaline armatūra (Biswas et al., 2020; Echevarria et al., 2018).

Pirmieji dispersinio armavimo panaudojimo pavyzdžiai aptinkami dar prieš kelis tūkstantmečius, kuomet statiniai iš molio buvo sutvirtinami šiaudais ar kitokiais natūraliais plaušais. Masinejje gamyboje plaušu armuoti kompozitai pasirodè devyniolikto amžiaus pabaigoje, atradus asbesto plaušą. Tai lèmé pirmojo industriniu būdu gaminamo didelio stiprumo fibrocementinio kompozito atsiradimą ir įsitvirtinimą statybos produktu pramonejje - beveik visą dvidešimtą amžių Hatcheko metodu buvo gaminami plonasieniai cementiniai stogų bei fasadų lakštai, armuoti asbesto plaušu, kol šis plaušas buvo pripažintas turintis kancerogenini poveiki (Jamshidia et al., 2011). Po II-ojo pasaulinio karo buvo atrasta nemažai naujo tipo plaušų, tai sudare sąlygas ir naujų statybinių kompozitų vystymuisi. 1950-aisiais tuometinèje Sovietų sajungoje pirmą kartą panaudotas E - tipo stiklo plaušu armuotas betonas su mažo šarmingumo rišikliu (Biryukovich, 1964). Iprastas portlandcementis negalëjo būti naudojamas dèl E - tipo plaušo intensyvios cheminès reakcijos su šarmais, todèl pirminis šių naujų kompozitų panaudojimas buvo labai ribotas (Grimer, 1969). 1960-aisiais Jungtinejje Karalysteje sukuriamas šarmams atsparus stiklo plaušas (AR - tipas), kuris pradedamas naudoti su Portlandcemenčio matrica. Tačiau dèl kokybės kontrolès stokos ir dèl nepakankamai geros plaušo kokybės pirmuose gaminiuose buvo pastebimas išankstinis trapumas, kai gaminiai eksploatuojami drégnoje aplinkoje ir pseudo-plastinè matrica laikui bėgant praranda plastiškumą. 1980-aisiais buvo žengti nauji žingsniai ir pa- 
tobulintas AR - tipo plaušas, taip pat pastebèta, kad akrilo polimero priedas padidina stiklo plaušu armuoto cementinio kompozito ilgaamžiškumą (Majumdar et al., 1977; Cohen et al., 1985; Bijen et al., 1982).

Nors XX amžiaus antroje pusejje inovatyvių statybos produktų sektoriuje dominavo stiklo plaušas, lygiagrečiai buvo tyrinèjamos ir kitos alternatyvos - anglies, bazalto ar polimerų plaušai. Anglies plaušo pramonè pagreitị igavo 1959-aisiais, kuomet Dr. Shindo Japonijoje užpatentavo anglies plaušo gamybos metodą, panaudojant brangią naftos produktų antrinę žaliavą - poliakrilnitrilą. Tačiau prireikè kelių dešimtmečių kol anglies plaušo gamybos būdai ištobulèjo ir šią medžiagą pradejjo naudoti ịvairios pramonès šakos. Iki šiol statybų sektoriuje šio plaušo panaudojimas yra labai ribotas dèl vis dar sąlyginai aukštos kainos (Tanaka et al., 2018; Bradley et al., 2016). Sovietų Sajungoje po antrojo pasaulinio karo nemažas dėmesys buvo skiriamas brangaus anglies plaušo alternatyvai - bazalto plaušui. Šio plaušo gamybos būdas iš esmès panašus ị stiklo plaušo, kuomet tam tikros uolienos išlydomos, homogenizuojamos su ịvairiais priedais ir karštai masei laisvai tekant per platinos - $10 \%$ rodžio lydinio matricą suformuojamos keliolikos mikronų skersmens gijos, kurios šaldomos staiga sukietēja ir yra suvyniojamos ị ištisinius stiklo (bazalto) plaušo verpalus (Fiore et al., 2015; Loewenstein et al., 1973; Frederick et al., 2009).

1951 metais JAV buvo susintetintas polipropilenas - vienas šiais laikais populiariausių kasdienio vartojimo plastikų. Betono savybių modifikavimas įmaišant ịvairių polimerinių plaušų mokslininkų tyrinejjamas pastaruosius keturis dešimtmečius. Betonui dažniausiai yra naudojami tokie sintetiniai polimerai kaip polivinilo alkoholis (PVA), polipropilenas (PP), polietilenas bei poliamidai. Pirmieji polimerinius plaušus betonui panaudojo JAV kariškiai 1965 m, siekdami padidinti statinių atsparumą priešo artilerijos smūgiams. Buvo pastebèta, kad polimerinis plaušas gerokai padidina betono smūginị tąsumą, t.y. trapi medžiaga tampa pseudo-plastiška (Sheldon et al., 1982; Ramaswamy et al., 1984). Kadangi polimerai natūraliomis lauko sąlygomis yra labai lètai, kai kurie mokslininkai laiko tai pranašumu prieš plieninę armatūrą, kuriai būdinga žymiai intensyvesnè korozija. Visiems statybų pramonejje naudojamiems polimeriniams plaušams būdingas labai žemas atsparumas aukštoms temperatūroms - gaisro atveju betone esantys plaušai greitai išsilydo ir jų vietoje lieka tik tuščios ertmès. Taip pat, polimerų tamprumo modulis retais atvejais viršija $10 \mathrm{GPa}$, o tai yra 20 kartų mažiau už ịprastinę plieno armatūrą. Dẻl mažo tamprumo modulio betoninis elementas neturi reikiamo standumo, gali per daug ịlinkti ir netenkinti vienos iš esminių projektavimo sąlygų - tinkamumo ribinių būvių (Sukontasukkul et al., 2004; Aulia et al., 2002). Tačiau polimeriniai plaušai dažniausiai naudojami betone kitu tikslu. Po daugelio mokslinių tyrimų bei praktinių pavyzdžių įrodyta, kad polipropileno mikroplaušas efektyviai sumažina betono plastinio susitraukimo deformacijas, kai 
betonuojami dideli plotai, ar masyvios konstrukcijos. Tokiu būdu yra eliminuojami trūkiai betone dèl susitraukimo džiūstant kietejjimo proceso metu (Yousefieh et al., 2017; Afroughsabet et al., 2017).

Plaušais armuoti betonai yra naudojami gamykliniams betono gaminiams formuoti. Tai gali būti naujų pastatų sieniniai elementai, istorinių pastatų fasado detalès, kraštotvarkos gaminiai, interjero detalès.

\subsection{Dispersiškai armuotụ betonụ gamybos technologija}

Smulkiagrūdžių betonų bazinei sudèčiai naudojamas ịprastinis portlandcementis, smulkus smèlis $\left(D_{\max }=2 \mathrm{~mm}\right)$, plastiklis, plaušas ir vanduo. Dažniausiai naudojamas užpildo - rišiklio santykis yra 1:1, stiklo plaušo kiekis 2-5\% nuo sausų medžiagų masès, vandens ir cemento santykis $0,3-0,4$. Sukietèjusio betono tankis, priklausomai nuo betono sudèties svyruoja tarp 1800-2200 kg/m³. Šiems betono mišiniams yra naudojamas žemas vandens ir cemento santykis $(\mathrm{V} / \mathrm{C}<0,4)$ ir sudètyje yra didelis kiekis smulkiujų dalelių, todèl ịprasti normaliojo betono maišymo būdai nèra tinkami, nes neužtenka energijos permaišyti dideli kiekị smulkių dalelių ir gauti reikiamą mišinio konsistenciją (Peter et al., 2015). Šiems smulkiagrūdžiams mišiniams yra iškirtinai naudojamas intensyvaus maišymo metodas, kai betono maišyklèje yra viena dideliu greičiu (iki $1500 \mathrm{aps} / \mathrm{min}$ ) besisukanti ašis su spiralès formos antgaliu (1.4 pav.).

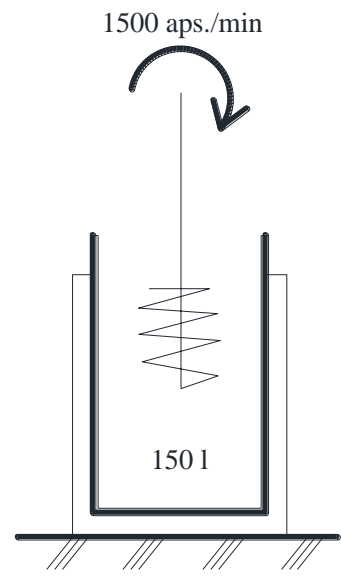

1.4 pav. Intensyvaus maišymo metodo schema (sudaryta autoriaus)

Fig. 1.4. Scheme for intensive concrete mixing (made by author) 
Tokių maišyklių talpa paprastai neviršija $150 l$, dažniausiai medžiagų dozavimas nèra pilnai automatizuotas, o mišinio ruošimo laikas užtrunka iki 5-10 min. Tuo tarpu normaliajam betonui skirtų maišyklių tūris paprastai siekia $1,5 \mathrm{~m}^{3}$ ir visų žaliavų dozavimas yra pilnai automatizuotas.

Galutinio produkto geometrinès charakteristikos bei mechaninès savybès nulemia, koks formavimo metodas yra pasirenkamas dispersiškai armuotu gaminių formavimui. Gaminio mechaninès savybès labai priklauso nuo šviežio mišinio sutankinamumo bei plaušo koncentracijos ir orientacijos cementineje matricoje. Tokie gamybos būdai, kaip vibro presavimas (ekstrūzija) ir takūs mišiniai, savaime užtikrina gerą betono sutankinimą. Tačiau dažnai naudojamas purškimo metodas reikalauja papildomo sutankinimo specialiu voleliu.

Takus mišinys dažniausiai naudojamas gaminant nesudètingų formų, dažniausiai plokščius gaminius, arba uždaro tipo děžinius elementus. Gaminio paviršiaus struktūrą galima keisti panaudojant poliuretano, gumos klojinius, ant kurių yra liejamas betono mišinys (1.5 pav.).

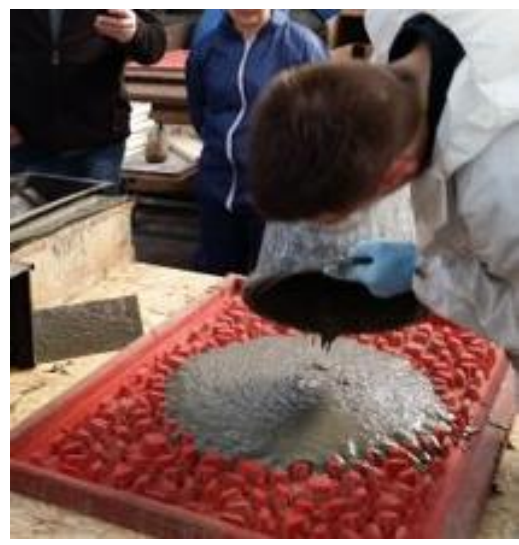

a)

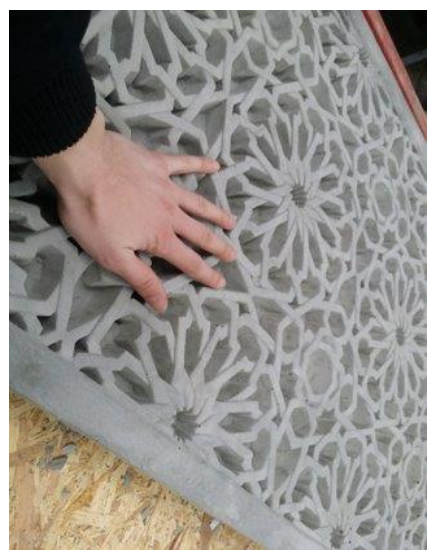

b)

1.5 pav. Takus stiklo plaušu armuotas betonas (asm. arhyvo nuotraukos):

a) forma; b) gaminys (autoriaus fotografijos)

Fig. 1.5. Self compacting glass fiber reinforced concrete (photos of personal archives): a) mould; b) casted element (photos made by author)

Purškimo metodas dažniausiai taikomas gaminant sudètingų geometrinių formų gaminius. Naudojamas sudètingos konstrukcijos ekscentrinis purkštuvas, $\mathfrak{i}$ kurị dozuojamas standus betono mišinys ir plaušo verpalų viena ar kelios gijos, kurios yra karpomos iki nustatyto ilgio (paprastai $25-40 \mathrm{~mm}$ ) (1.6 pav.). 


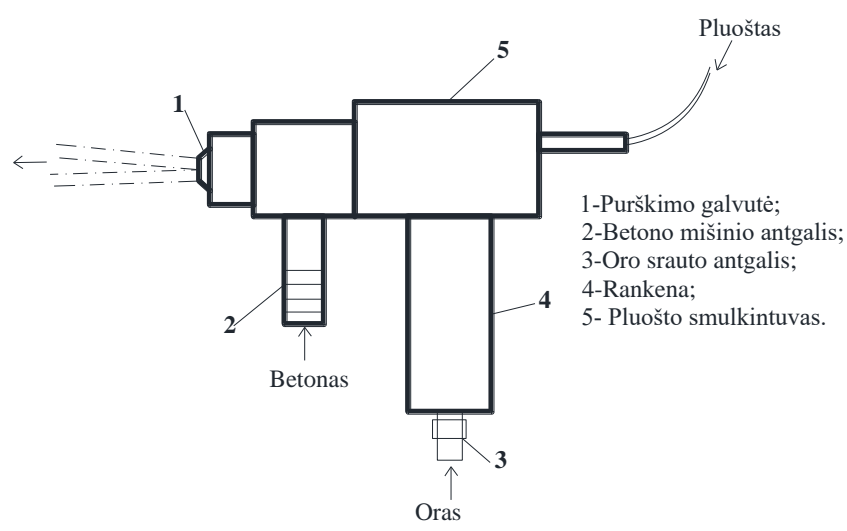

1.6 pav. Ekscentrinis purkštuvas (sudaryta autoriaus)

Fig. 1.6. Excentric spray gun (made by author)

Suspausto oro pagalba plaušas išpučiamas kartu su betono mišiniu ant klojinio paviršiaus. Tokiu būdu $12-15 \mathrm{~mm}$ storio betono gaminys yra suformuojamas purškiant betoną 3-4 sluoksniais. Pirmas 3-5 mm sluoksnis gali būti formuojamas kaip apdailinis, ịmaišant ị betoną ịvairius pigmentus, ar netgi tokius priedus kaip nano titano dioksidas, su kuriuo betono paviršiai tampa savaime nusivalantys nuo purvo ir filtruojantys atmosferoje esantị diazoto oksidą $\mathrm{N}_{2} \mathrm{O}$. Išpurškus kiekvieną sluoksnį, visas paviršius yra voluojamas, tokiu būdu sutankinant šviežią mišinị ir užtikrinant, kad mišinys pilnai liestųsi su klojiniu, sluoksniai sukibtų vienas su kitu ir būtų pašalintos tuštumos (poros) tarp plaušo ir matricos. Gaminant šiuo būdu, plaušas pasiskirsto tik horizontalioje plokštumoje - tempimo jègų veikimo kryptimi, todèl gaunamas žymiai didesnis betono lenkimo stipris nei naudojant takų mišinį.

\subsection{Dispersiškai armuotų smulkiagrūdžių betonų savybių apžvalga}

Dispersiškai armuoto smulkiagrūdžio betono mechaninès savybės priklauso nuo tokių faktorių kaip gamybos būdas, plaušo tipas bei kiekis, kietèjimo sąlygos, cementinès matricos struktūra. Pasirinktas gamybos būdas nustato reikiamą betono mišinio konsistenciją, kuri priklauso nuo tokių pagrindinių faktorių kaip vandens ir cemento santykis, plaušo kiekis ir tipas bei pasirinkto užpildo dalelių forma. 


\subsubsection{Mišinių konsistencija}

Betono paviršių kokybę įtakoja tokie pagrindiniai faktoriai kaip klojinių tipas ir jų paruošimas, mišinio sutankinamumas bei konsistencija. Esant netinkamos konsistencijos mišiniui, vien klojiniais ir intensyviai tankinant betoną pasiekti norimą rezultatą yra labai sudètinga, o dažnai net neịmanoma. Todèl tyrinėjant smulkiagrūdžius apdailinius betonus labai svarbu atsižvelgti ị mišinio konsistenciją ịtakojančius rodiklius.

Daugybė mokslinių tyrimų jau atlikta nagrinejjant betonų superplastiklių efektyvumą, vandens ir cemento (V/C) santykio poveikị mišinių konsistencijai, todèl tikslinga būtų tyrinèti tokius rodiklius, $\mathfrak{i}$ kuriuos mažiau kreipiamas dèmesys, tačiau jie taip pat yra labai svarbūs - tai plaušo tipas ir užpildo dalelių forma.

Branston (2016) atlikti betono konsistencijos tyrimai parodè, kad dozuojant $12 \mathrm{~kg} / \mathrm{m}^{3}$ ir $40 \mathrm{~kg} / \mathrm{m}^{3}$ bazalto plaušo betono mišinio neịmanoma išmaišyti, nes mišnys pasidaro standus, o plaušas sulimpa. Tačiau dozuojant mažesniais kiekiais $\left(1-2 \mathrm{~kg} / \mathrm{m}^{3}\right)$, bazalto plaušas buvo efektyviai panaudotas betono plastinio susitraukimo džiūstant deformacijoms sumažinti.

Yakhlaf (2013) nustate, kad anglies plaušas stipriai pablogino susitankinančio normaliojo betono mišinio konsistenciją, kai plaušo buvo dozuojama $0,25 \%$ nuo sausų medžiagų masès. Safiudin (2018) ištyrè, kad betono gniuždymo stipris sumažèjo iki $58 \%$ dèl plaušo ịtakos. Tačiau skèlimo stipris padidejo atitinkamai iki $17 \%$ lyginant su bandiniais be plaušo. Skenuojančiu elektroniniu mikroskopu darytos nuotraukos atskleidè, kad anglies plaušeliai betono matricoje išliko tiesios formos, nebuvo susikraipę ar susisukę ị kamuolius.

Peter (2015) pavyko pagaminti takų cementini skiedini panaudojus $3 \%$ plaušo nuo rišiklio masès. Rišikliu buvo pasirinktas CEM I 52,5R klasès portlandcementis, mišinio konsistencijai pagerinti - polikarboksilatų esterio superplastiklis, užpildas - smulkus kvarcinis smèlis $\left(D_{\max }=2 \mathrm{~mm}\right)$, vandens ir cemento santykis $\mathrm{V} / \mathrm{C}=0,36$. Superplastiklio kiekis tyrimo autorių nebuvo ịvardintas. Pastebèta, kad standartinis konsistencijos vertinimo metodas pagal LST EN 1170-1 netinka, kadangi visais atvejais buvo gaunamas maksimalus mišinio pasklidimas. Todẻl pasirinkta matuoti mišinio ištekèjimo laiką iš 31 talpos indo per $19 \mathrm{~mm}$ skersmens vamzdelị. Keičiant superplastiklio kiekius, ištekëjimo laikas kito nuo $80 \mathrm{~s}$ iki $29 \mathrm{~s}$.

Abe (2015) tyrinejjo takius skiedinius su stiklo plaušu ir skirtingais priedais (metilceliulioze, akrilo polimeru, $\mathrm{SiO}_{2}$ mikrodulkėmis, orą ịtraukiančiu bei orą išstumiančiu ir mišinio sluoksniavimąsi mažinančiomis įmaišomis). Visų mišinio komponentų kiekiai buvo vienodi, keičiami tik priedai. Vandens cemento santykis $\mathrm{V} / \mathrm{C}=0,3$, o plaušo kiekis $3 \%$ nuo cemento masès. Didžiausias mišinio pasklidimas gautas su mišinio sluoksniavimąsi mažinančiu priedu, o betono lenkimo stipris svyravo tarp 11-15 MPa. 
Pastaraisiais dešimtmečiais sparčiai mažejjant natūralaus iškastinio smèlio resursams statybų pramoneje sunaudojama vis daugiau trupintų uolienų užpildų. Nors abiem atvejais dalelių dydis yra panašus, tačiau skiriasi šių dviejų, skirtingais būdais gaunamų, smèlių dalelių morfologija. Dẻl gamtoje vykstančių ilgalaikių mechaninių poveikių, natūralaus smèlio dalelèms visada yra būdingas sferiškumas ir glotnus paviršius. Kadangi dirbtinis smèlis gaunamas skaldant ir trupinant uolienas, šioms dalelèms būdingas šiurkštus paviršius, aštrūs kampai ir pailga forma.

Kadangi betono mišinys yra sudarytas iš įvairių tarpusavyje sąveikaujančių dalelių, tų dalelių forma atlieka svarbų vaidmenį kalbant apie betono mišinio reologines savybes (pasklidimą bei mišinio stabilumą). Užpildo dalelès formą nusako trys pagrindiniai parametrai: sferiškumas, plokštumas bei pailgumas (Powers, 1953 ), (1.7 pav.). Tikrojo sferiškumo indeksas apibūdinamas kaip rutulio, tokio pat tūrio kaip dalelè, paviršiaus ploto ir dalelès paviršiaus ploto santykis (Wadell et al., 1933 ). Akivaizdu, kad ị diską panašių kūnų sferiškumas gali atrodyti toks pat, kaip ir pailgos formos, nepaisant jų skirtumų.

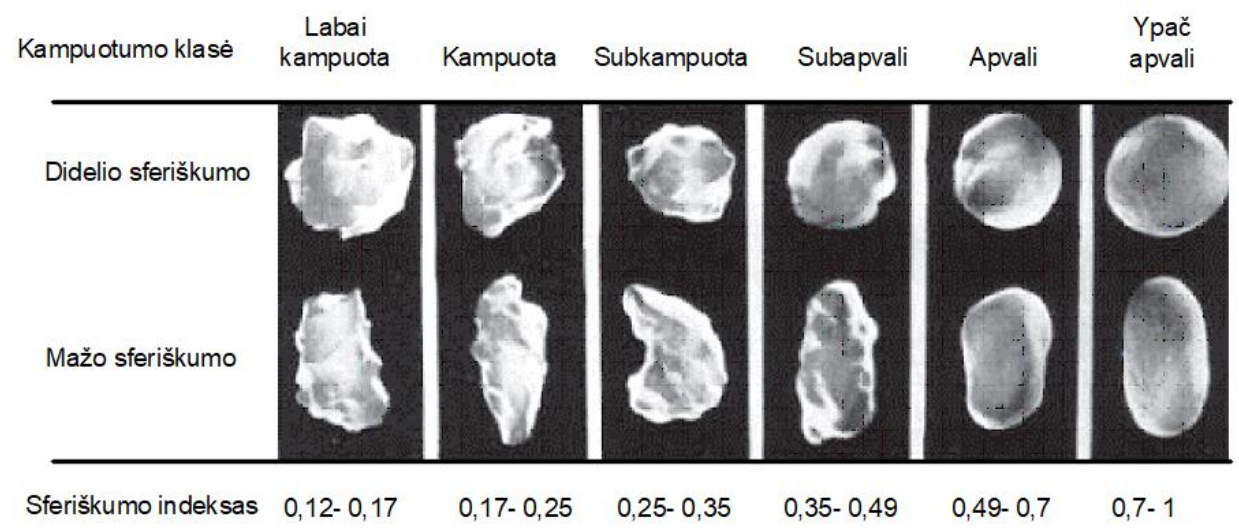

1.7 pav. Daleliu formos klasifikavimas pagal Powers

Fig. 1.7. Roundness class according to Powers (Zheng J. 2015 )

Dalelių formos apibrèžimas gali atrodyti painus kalbant apie teorinių skaičiavimų pritaikymą praktikoje. Todèl kai kurie tyrèjai pasiūlè naudoti diagramas dalelių vizualiam palyginimui ir jų formos apibūdinimui. Šios diagramos galètų palengvinti dalelių apvalumo ir sferiškumo lygio įvertinimą, panaudojant ịprastines vizualines priemones (Zheng et al., 2015). Zingg (1935) daleles suklasifikavo naudodamas pailgumo (IL) ir plokštumo koeficientus (SL). Krumbein (1941) pateikè apvalumo palyginimo diagramą. Powers (1953) pasiūlè apvalumo skalę, kad būtų galima vizualiai palyginti ir rankiniu būdu nustatyti apvalumo ir sferiškumo vertes. Be to, Krumbein ir Sloss (1963) pasiūlè dalelių sferiškumo ir apskritumo 
kombinacijų diagramą, kad ịvertinti dalelių formą. Tada Cho (2006) modifikavo šią diagramą apibrèždamas dalelès formą kaip apskritumo ir sferiškumo aritmetinị vidurkị bei pridèdamas punktyrinę liniją prie siūlomos formos. Lees (1964) pasiūle diagramą vizualiam dvimačiui (2D) dalelių kampuotumui ịvertinti. Blott ir Pye (2007) apjungè kitų autorių atliktus tyrimus ir pateikè keletą grafikų, apibūdinančių dalelių formą.

\subsubsection{Mechaninès savybès}

Pastaruosius tris dešimtmečius mokslininkai deda daug pastangų kurdami ypač didelio stiprumo cementbetonius. Šie kompozitai susideda iš portlandcemenčio, inertinių mikroužpildų (maltas kvarcas), aktyvių mikroužpildų $\left(\mathrm{SiO}_{2}\right.$ mikrodulkès, metakaolinas), superplastifikatoriaus bei plieninių mikroplaušų. Šių betonų gniuždymo stipris paprastai siekia 150-200 MPa (Shi C. 2015). Prie specialių kietejjimo sąlygų, pavyzdžiui temperatūrą pakèlus iki $400{ }^{\circ} \mathrm{C}$ ir veikiant $40 \mathrm{MPa}$ slègiui, betonas gali pasiekti $800 \mathrm{MPa}$ gniuždymo stiprị (Richard et al., 1995).

Šiame darbe nagrinèjami smulkiagrūdžiai betonai su nemetaliniais plaušais, todèl jų mechaninès savybès skiriasi nuo prieš tai paminètų smulkiagrūdžių betonų su plieno mikroplaušu. Tačiau cementinès matricos taip pat ir jų modifikavimo būdai abiem atvejais yra panašūs. Labiausiai ištyrinètas mokslininkų ir naudojamas praktikoje yra dispersinis armavimas stiklo plaušu. Pagrindinès šio kompozito mechaninès savybès pateiktos 1.1 lentelèje.

Mokslininkų atlikti tyrimai parodè, kad takaus stiklo plaušu armuoto smulkiagrūdžio betono lenkimo stipris siekia 10-15 MPa, priklausomai nuo plaušo kiekio ir cementinès matricos sudèties. Peter (2015) nagrinèjo lenkimo stiprio priklausomybę nuo stiklo plaušo kiekio, plaušo ilgio, vandens ir cemento santykio ir plastifikatoriaus kiekio. Portlandcementis CEM I 52R buvo naudojamas kaip rišiklis, polikarboksilatų pagrindo superplastiklis kaip konsistenciją gerinanti įmaiša ir kvarcinis smèlis kaip užpildas. Bandymai parodè, kad lenkimo stipris padidèjo nuo $8 \mathrm{MPa}$ iki $12 \mathrm{MPa}$, kai vandens ir cemento santykis buvo sumažintas nuo 0,42 iki 0,32 . Plaušo kiekis turèjo didesnę įtaką lenkimo stipriui negu plaušo ilgis, kai buvo naudojami $12,5 \mathrm{~mm}$ ir $25 \mathrm{~mm}$ plaušai. Gautas vidutinis lenkimo stipris su $12,5 \mathrm{~mm}-9 \mathrm{MPa}$ o su $25 \mathrm{~mm}-10 \mathrm{MPa}$, kai plaušų kiekis $3 \%$ nuo sausų medžiagų masès. Lenkimo stipris padidèjo nuo $8 \mathrm{MPa}$ iki $13 \mathrm{MPa}$, kai $13 \mathrm{~mm}$ ilgio plaušo kiekis buvo padidintas nuo $2 \%$ iki $4 \%$. Abe (2011) nagrinèjo stiklo plaušu armuotus betono mišinius su įvairiomis įmaišomis (orą įtraukiančiomis, skirtingo tipo plastifikatoriais, stabilizatoriumi, akrilo polimeru, metilceliulioze bei silicio dioksido mikrodulkèmis). Visų mišinių vandens ir cemento santykis buvo 0,3 , plaušo kiekis $-3 \%$, o rišiklio ir kvarcinio smèlio užpildo santykis 1:1. Geriausia mišinio konsistencija gauta su plastifikuojančiu stabilizatoriumi, o 
visų bandinių lenkimo stiprumas svyravo tarp 11-15 MPa, be ryškios koreliacijos kuriam nors komponentui.

1.1 lentelė. Smulkiagrūdžio stiklo plaušu armuoto betono pagrindinès mechaninès savybès (Bartos, 2017)

Table 1.1. Main mechanical properties of glass fiber reinforced concrete (Bartos, 2017)

\begin{tabular}{|l|c|c|}
\hline Mechaninės savybės (po 28 parų) & $\begin{array}{c}\text { Purškiamas } \\
\text { betonas }\end{array}$ & $\begin{array}{c}\text { Takus } \\
\text { betonas }\end{array}$ \\
\hline Betono tankis, $\mathrm{kg} / \mathrm{m}^{3}$ & $1900-2100$ & $1800-2000$ \\
\hline Deformacijų modulis, GPa & \multicolumn{2}{|c|}{$10-20$} \\
\hline Lenkimo stipris, $\mathrm{MPa}$ & $18-30$ & $5-14$ \\
\hline Gniuždymo stipris, MPa & $40-60$ & $50-80$ \\
\hline Smūginis tąsumas, $\mathrm{kJ} / \mathrm{m}^{2}$ & $7-12$ & $15-25$ \\
\hline
\end{tabular}

Apie alternatyvių plaušų (bazalto, anglies, PVA) panaudojimą smulkiagrūdžio betono matricos armavimui yra mažai duomenų, mokslininkų atlikti tyrimai apsiriboja ties šių plaušų panaudojimu normaliesiems (stambiagrūdžiams) betonams.

Jiang (2014) nustatè, kad bazalto plaušas betono gniuždymo bei lenkimo stiprius padidina efektyviau nei polipropilenas, atitinkamai $4,68 \%$ ir $9,58 \%$ iki 47,48 MPa ir 8,4 MPa. Plaušo ilgis (12 mm arba $24 \mathrm{~mm}$ ) reikšmingos įtakos sripruminių savybių pokyčiams neturejjo. Urkhanova (2014) pagerino bazalto plaušu armuoto normaliojo betono mechanines savybes plaušą impregnuojant nano $\mathrm{SiO}_{2}$ (silicio dioksido nano suspensijoje). Plaušą dozuojant iki $3 \mathrm{~kg} / \mathrm{m}^{3}$, betono gniuždymo bei lenkimo stipris padidèjo atitinkamai $27 \%$ ir $60 \%$.

Naujausių mokslinių tyrimų duomenimis, galima pagerinti bazalto plaušo sukibimą su cementine matrica, bazaltą impregnuojant anglies nano vamzdelių suspensijoje. Förster (2016) nustatè, kad anglies nano vamzdeliai chemiškai reaguoja su bazalto plaušo paviršiumi, taip prie jo prisitvirtindami ir veikia kaip papildomi struktūriniai elementai, pagerinantys plaušo kontakto zoną su cementine matrica. Yakovlev (2015) nustatè, kad anglies nano vamzdeliais modifikuotas bazalto plaušas padidino betono kompozito gniuždymo ir lenkimo stiprius atitinkamai $25 \%$ ir $92 \%$.

Polivinilo alkoholio plaušas (PVA) turi didelę itaką betone atsiveriančių mikro ịtrūkimų ir didesnių plyšių suvaržymui. Mokslininkų nustatyta, kad PVA plaušas pagerina betono mechanines savybes sumažindamas dèl valkšnumo efekto atsirandančius plyšius, dèl ko padidejja betono ilgaamžiškumas (Sprince et al., 2013; Sprince et al., 2016). Arisoy (2008) ir Toutanji (2010) nustatè, kad 
PVA plaušas padidino normaliojo betono lenkimo plastiškumą (ilinkị prie maksimalios apkrovos) iki 50-150 kartų, o lenkimo stiprị iki 50-250\%.

\subsection{Skirtingų betono komponentų charakteristikos ir panaudojimas}

Pagrindinès plaušų fizikinès bei mechaninès savybès, kurios charakterizuoja jų panaudojimo galimybes smulkiagrūdžio betono gaminių armavimui yra šios:

- Plaušo tempimo stipris, MPa, kuris lemia betono tempimo bei lenkimo stiprius.

- Deformacijų modulis, GPa. Kuo didesnis plaušo deformacijų modulis, tuo didesnis gaminio atsparumas lenkimo, tempimo deformacijoms. Pavyzdžiui, įprasto betono deformacijų modulis gniuždant arba tempiant siekia $40 \mathrm{MPa}$. Todèl, siekiant užtikrinti, kad gaminiai neviršytų ribinių deformacijų ir nepradètų pleišèti, plaušo deformacijų modulis negali būti mažesnis nei betono (Ngab et al., 2020; Paeglea et al., 2016; Gribniak et al., 2013).

- Atsparumas šarmams. Cementinei matricai būdingas didelis šarmingumas, kuris plieną saugo nuo korozijos, tačiau chemiškai ardo kai kuriuos plaušus, todèl jie turi būti tinkamai apsaugoti nuo šarmų poveikio.

- Lydymosi temperatūra ir terminis atsparumas. Gyvenamuose arba komercinès paskirties pastatuose reikalaujamas pakankamai aukštas visų statinio elementų atsparumas ugniai, kuris dažnai išreiškiamas kaip minimalus laikas per kurị žmonès gali saugiai pasišalinti iš pastato vykstant gaisrui. Dažniausiai yra reikalaujama 60-90 minučių.

- Plaušo struktūra ir geometriniai matmenys. Šie parametrai lemia tiek mišinio konsistenciją, tiek sukietejusio betono mechanines savybes, kurios priklauso nuo tinkamo plaušo pasiskirstymo tūryje ir sukibimo su cementine matrica.

Komercinio stiklo gamyboje naudojamas kvarcas, kuris yra išlydomas ir modifikuojamas ịvairiais metalu oksidais $\left(\mathrm{SiO}_{2} 69,9 \%, \mathrm{Al}_{2} \mathrm{O}_{3} 2,6 \%, \mathrm{CaO} 5,4 \%\right.$, $\mathrm{MgO} 3,6 \%, \mathrm{Na}_{2} \mathrm{O} 16,8 \%$ ) (Paul, 1977). Dèl intensyvios cheminès korozijos šarminejje terpejje, iprastinio stiklo plaušo negalima naudoti sistemose su portlandcemenčio rišikliu. 1960-aisiais sukurto šarmams atsparaus stiklo cheminė sudètis buvo patobulinta ịtraukiant cirkonio oksidą: $\mathrm{SiO}_{2} 71 \%, \mathrm{ZrO}_{2} 16 \%, \mathrm{Na}_{2} \mathrm{O} 12 \%$ and $\mathrm{Li}_{2} \mathrm{O} 1 \%$. Majumdar (1977) tyrinejo $10 \mu \mathrm{m}$ diametro šarmams atsparaus stiklo plaušo reakciją su portlandcemenčiu skirtingose temperatūrose nuo $20{ }^{\circ} \mathrm{C}$ iki $65^{\circ} \mathrm{C}$. Bandymai parodè, kad naujasis cirkoniu modifikuotas stiklas vis tiek 
praranda dali pirminio stiprumo veikiant šarmams. Reakcijos greitis dideja kartu su temperatūra ir esant $20^{\circ} \mathrm{C}$ aplinkos temperatūrai, nustatytas ilgalaikis stiklo plaušo tempimo stipris šarminejje terpeje - $1200 \mathrm{MPa}$.

1.2 lentelè. Skirtingų plaušų maksimalios mechaninès charakteristikos ir terminis atsparumas.

Table 1.2. Maximum mechanical properties and thermal resistance of different fibers.

\begin{tabular}{|l|c|c|c|c|}
\hline \multirow{2}{*}{ Pagrindinès charakteristikos } & \multicolumn{4}{|c|}{ Skirtingų plaušų savybės } \\
\cline { 2 - 5 } & Stiklas & Bazaltas & Anglis & PVA \\
\hline Tempimo stipris, $\mathrm{MPa}$ & 1500 & 3200 & 7000 & 1500 \\
\hline Deformacijų modulis, $\mathrm{GPa}$ & 74 & 90 & 440 & 40 \\
\hline Terminis atsparumas, ${ }^{\circ} \mathrm{C}$ & $-50 \ldots+350$ & $-260 \ldots+700$ & 300 & 100 \\
\hline Lydymosi temperatūra, ${ }^{\circ} \mathrm{C}$ & 1100 & 1200 & 1200 & 200 \\
\hline
\end{tabular}

Orlovsky (2005) tyrinejo šarmų poveiki šarmams atsparaus stiklo plaušo ilgaamžiškumui, kai plaušas buvo panardinamas $13,5 \mathrm{pH}$ tirpale $50^{\circ} \mathrm{C}$, neveikiant išorinèms apkrovoms. Po 45 parų bandiniai prarado iki $60 \%$ pradinio tempimo stiprio. Autoriai patikrino plaušelių skersmeni po bandymo ir nenustate jokio sumažèjimo. Tyrinėdami plaušo paviršių skenuojančiu elekroniniu mikroskopu, autoriai aptiko pavienius $40 \mathrm{~nm}$ dydžio defektus. Šiuo tyrimu nustatyta, kad cirkonio dioksidu modifikuoto stiklo senejjimas šarminèje terpejje nèra vien tik cheminis procesas ir gali būti labiau susijęs su paviršinių defektų atsiradimu.

Bazalto plaušas gaminamas iš vulkaninès kilmès uolienų, kurių lydymosi temperatūra siekia $1500-1700{ }^{\circ} \mathrm{C}$. Šias uolienas sudaro piroksenų grupès mineralai, kurių sudètyje vyrauja ir kai kurie stiklo plaušui būdingi oksidai: $\mathrm{SiO}_{2}$ (44-47\%), $\mathrm{Al}_{2} \mathrm{O}_{3}(11-13 \%), \mathrm{CaO}(10-12 \%), \mathrm{MgO}(8-11 \%), \mathrm{K}_{2} \mathrm{O}, \mathrm{Na}_{2} \mathrm{O}, \mathrm{Fe}_{2} \mathrm{O}_{3}$ $(<5 \%)$ (Fiore et al., 2015; Dhand et al., 2015; Khandel et al., 2020). Kadangi bazalto cheminè sudètis artima komerciniam stiklui, tikètina, kad šiam plaušui taip pat būdingos reakcijos su cemento šarmais. Lee (2014) nustaté, kad po 90 parų mirkymo šarmų tirpale bazalto plaušas prarado iki $40 \%$ pradinès masès bei $80 \%$ pradinio stiprumo. Robinovic (2001) ir Wu (2011) atliko bandymus panardinant bazalto plauša $\mathrm{Ca}(\mathrm{OH})_{2}$ prisotintame tirpale. Nustatyta, kad po 3 ménesių plaušas praranda iki $60 \%$ pradinio stiprumo, o po 12 mèn. - $100 \%$. Plaušo reakcijos su šarmais greitis taip pat didèja kylant aplinkos temperatūrai (Afroz et al., 2017). İvairūs mokslininkai tyrinèja būdus, kaip pagerinti bazalto plaušo atsparumą šarmams. Tiek mokslininkų, tiek pramoninejje bazalto plaušo gamyboje yra bandoma apsaugoti plaušo paviršių įvairiomis dangomis. Myadaraboina 
(2015) ištyrè, kad padengus plaušą silano polimerais pilnai išlaikomos pradinès charakteristikos, kai plaušas buvo mirkomas 62 paras $\mathrm{NaOH}$ tirpale. Taip pat teigiamų rezultatų dave $\mathrm{ZrO}_{2}$ ir $\mathrm{TiO}_{2}$ dangos (Rybin et al., 2013; Baklanova et al., 2013).

Daugiau kaip $90 \%$ anglies plaušo pagaminama naudojant poliakrilnitrilo žaliavą. Iš pradžių atliekama karbonizacija $400-1500{ }^{\circ} \mathrm{C}$ temperatūrų intervale, pašalinant nereikalingus elementus, kurie sudaro ịvairius junginius su anglies atomais (vandenilis, deguonis, azotas ir kt.). Taip suformuojamos pirminès turbostratinès struktrūros grafito grandinès ir gaunamas didelio stiprumo pluoštas. Siekiant padidinti deformacijų modulį, temperatūra keliama iki $220^{\circ} \mathrm{C}$, kurioje grafito grandinès dar labiau orientuojamos išilgai plaušo (Frank et al., 2014; Lu et al., 2020).

Polivinilo alkoholio plaušas (PVA) - tai sintetinis plaušas, laikomas vienu tinkamiausiu polimerų cementinès matricos armavimui (Saida et al., 2020). PVA gaminamas hidrolizès būdu iš polivinilo acetato, naudojant etanoli, kaip katalizatorių. Dẻl savo sudètyje esančių hidroksilo grupès jonų (-OH), PVA plaušas pasižymi ypač tvirtu cheminiu ryšiu su cementine matrica bei atsparumu neigiamam cemento šarmų poveikiui (Yang et al., 2010; Zhou et al., 2017). PVA pasižymi dideliu tempimo stipriu bei deformacijų moduliu, atitinkamai $1500 \mathrm{MPa}$ ir $40 \mathrm{GPa}$ (Ahmad et al., 2018). PVA lydymosi temperatūra $-200{ }^{\circ} \mathrm{C}$, kai tuo tarpu polipropileno $-160^{\circ} \mathrm{C}$, polietileno $-115^{\circ} \mathrm{C}$. Atlikti eksperimentiniai tyrimai rodo, kad PVA plaušu armuotas betonas praranda iki $17 \%$ pradinio lenkimo stiprio, kai temperatūra pasiekia $145^{\circ} \mathrm{C}$ (Magalhães et al., 2013). Kiti tyrimai parodè, kad veikiant $400{ }^{\circ} \mathrm{C}$ temperatūrai, betoninių prizmių su PVA lenkimo stipris buvo $45 \%$ didesnis negu kontrolinių bandinių be plaušo (Tanyildizi et al., 2016).

Dispersiškai armuotų betonų mechaninių savybių pastovumo užtikrinimas tai labai svarbus uždavinys tobulinant esamus ir kuriant naujus cementinius kompozitus. Šių kompozitų korozijos (senejjimo) procesus galima nuslopinti trimis būdais, nagrinejjamais mokslineje literatūroje: modifikuojant plaušų cheminę sudèti, keičiant plaušo paviršiaus struktūrą ir modifikuojant cementinę matricą.

Akrilo polimerai betono pramonèje buvo pradèti naudoti 1980-aisiais, kaip betono kietinimo agentas, padedantis sutrumpinti betono gaminių kietinimo laiką, kuris tuo metu siekdavo 7 paras. Tačiau betono gamyboje yra plačiai naudojami modernūs polikarboksilatų esterio pagrindu gaminami superplastikliai, kurie leidžia sumažinti vandens ir cemento santykị, gaunant reikiamą mišinio konsistenciją ir todèl 7 paru kietinimas drègnoje aplinkoje nèra būtinas (Rickard et al., 2015).

Kai kurie mokslininkai teigia, kad akrilo polimerai gali padidinti siklo plaušu armuoto betono ilgaamžiškumą. Akrilo polimerų suspensija paprastai dozuojama tarp 7-10 \% nuo cemento masès. Ball H (1993) tyrinèjo bandinius paimtus iš Didžiosios Britanijos klimato sąlygomis 19 metų eksploatuojamo pastato stiklo 
plaušu armuoto betono fasado, kur gamybos metu buvo panaudota akrilo polimero suspensija. Nustatyta, kad bandiniai kurie buvo gaminti be akrilo polimero po 19 metu prarado iki $40 \%$ pradinès deformacijos (plastiškumo), o elementai su $7 \%$ akrilo beveik pilnai išlaikè pradines pseudo-plastines charakteristikas. Taip pat buvo pastebèta, kad džiovinimo - drèkinimo bandymo metodas geriau atspindi realius senejjimo procesus negu mirkymas karštame vandenyje. Qian X (2003) tyrinejjo polivinilo alkoholio (PVA) miltelių priedo įtaką stiklo plaušu armuoto kompozito ilgaamžiškumui. $6 \mathrm{~mm}$ storio bandiniai buvo laikomi $20{ }^{\circ} \mathrm{C}$ temperatūros vandenyje pagal Litherland metodiką. Plokštelių tempimo stiprumo bandymai parodè, kad PVA priedas turi teigiamą itaką kompozito ilgaamžiškumui, padidindamas tempimo stiprị ir išlaikydamas pirmines plastines savybes. Šio priedo efektyvumas buvo išaiškintas apžiūrẻjus plaušo - matricos kontako zonas, kur buvo matomos plonos apsauginès plèvelès, galimai saugančios nuo žalingo portlandito kristalų poveikio.

Aktyvūs mineraliniai priedai dažnai naudojami kaip betono komponentai kuriems būdingos pucolaninès reakcijos su portlandito fazèmis. Dẻka šių reakcijų sumažinama $\mathrm{Ca}(\mathrm{OH})_{2}$ kristalų koncentracija, kurie augdami pažeidžia plaušo paviršių ir blogina kompozito ilgalaikes mechanines savybes. Dèl ypatingo smulkumo šie priedai sutankina cementini akmeni, gerina ryšị tarp cemento ir užpildo dalelių, taip pagerindami cementinès matricos mechanines savybes. Tai gali būti paaiškinama poveikiu tarpinès fazès storiui tarp užpildo dalelių ir cementinès tešlos, taip pat $\mathrm{CH}$ fazès kristalų orientacijai.

Silicio dioksido mikrodulkès $\left(\mathrm{SiO}_{2}\right)$ yra silicio ir ferosilicio pramonès šalutinis produktas. Redukuojant gryną kvarcą iki silicio, esant temperatūrai iki $2000{ }^{\circ} \mathrm{C}$, susidaro $\mathrm{SiO}_{2}$ garai, kurie žemos temperatūros zonoje oksiduojasi ir kondensuojasi iki mažų dalelių, susidedančių iš nekristalinio silicio dioksido (Siddique et al., 2011). Dèl pucolaninių reakcijų tarp $\mathrm{SiO}_{2}$ ir kalcio hidroksido susiformuoja papildomi kalcio hidro silikatai (CSH), kurie išauga ị tuštumas aplink hidratuotas cemento daleles. Tarpinès fazès zonos tankio didinimas ir ryšio tarp cemento bei užpildo dalelių gerinimas panaudojant $\mathrm{SiO}_{2}$ mikrodulkių priedą buvo ne kartą îrodytas mokslininkų atliktais tyrimais (Köksal et al., 2008; Tasdemir et al., 2002). Naudojant $\mathrm{SiO}_{2}$ mikrodulkių priedą betone, reikšmingai sumažèja chlorido jonų difuzija. Tai gali būti siejama su tuo, kad vykstant pucolaninèms reakcijoms kartu su cemento hidratacija stambios poros suskaidomos $\mathfrak{i}$ mažesnes. $\mathrm{SiO}_{2}$ mikrodulkès pagerina ilgalaikị atsparumą betono šarminei korozijai, tačiau padidina karbonizacijos gyli (Khana et al., 2011). Bartos (1996) atlikti sitklo plaušu armuoto kompozito tyrimai parodè, kad silicio dioksido mikrodulkių priedas pagerina šios medžiagos ilgalaikes mechanines savybes.

Metakaolinas (MK), arba $\mathrm{Al}_{2} \mathrm{Si}_{2} \mathrm{O}_{7}$ yra gaunamas kalcinuojant kaolinito moli 700-800 ${ }^{\circ} \mathrm{C}$ temperatūroje. Dehidroksilizacija vyksta paveikus kaolinitą aukšta 
temperatūra nustatytą laiko tarpą. Metakaolino (MK) pocolaninis aktyvumas cementiniame akmenyje yra plačiai ištyrinètas ir apibūdinamas kaip naujų kalcio hidro silikato fazių susidarymas $\left(\mathrm{C}_{2} \mathrm{ASH}_{8}, \mathrm{C}_{4} \mathrm{AH}_{13}\right.$ ir $\left.\mathrm{C}_{3} \mathrm{AH}_{6}\right)$. Mokslininkų atlikti tyrimai pakeičiant dalị cemento metakaolinu (nuo $10 \%$ iki $25 \%$ ) parodè, kad šis priedas pagerino cementinio akmens mechanines savybes bei padidino ilgaamžiškumą (Poon et al., 2001; Brooks et al., 2001; Courard et al., 2003). Pagrindiné metakaolino panaudojimo problema cementinèje tešloje yra padidejęs vandens poreikis, kurị lemia didelis dalelių specifinis paviršiaus plotas $\left(17 \mathrm{~m}^{2} / \mathrm{g}\right)$ ir netaisyklinga morfologinè struktūra - metakaolino dalelès yra plokštelių pavidalo) (Bai et al., 2003; Li et al., 2003).

Atlikus tyrimus su stiklo plaušu armuotais kompozitais, Brandt (2003) nustatè, kad kontroliniai bandiniai, be priedo, prarado $85 \%$ pradinio lenkimo stiprio po 84 paru mirkymo $50{ }^{\circ} \mathrm{C}$ temperatūros vandenyje. Bandiniai, kuriuose $40 \%$ cemento buvo pakeista metakaolino priedu, beveik neprarado pradinių mechaninių savybių laikant juos analogiškomis sąlygomis. SEM - EDX analizès pagalba nustatyta, kad tarp stiklo pluošto plaušelių neatsirado portlandito kristalų intarpų, kuo buvo paaiškinta teigiama metakaolino įtaka stiklo plaušu armuoto kompozito ilgaamžiškumui.

Plaušo paviršiaus struktūros modifikavimas įvairiais impregnantais bei dangomis yra dažnai naudojamas metodas plaušų gamintojų, siekiant pagerinti jų ilgalaikes charakteristikas naudojant juos cementinèse sistemose ir padidinti plaušu atsparumą įvairiems mechaniniams poveikiams transportavimo bei mišinio maišymo metu. Naujausios kartos $\mathrm{ZrO}_{2}$ sudètyje turintys stiklo plaušai yra padengiami keletos nano metrų storio organinių silano polimerų dangomis. İvairūs mokslininkai tyrinejjo šių dangų ịtaką stiklo plaušo savybėms. Silano polimerai plaušo paviršiuje sudaro erdvinius tinklelius, kurių dẻka padidejja sukibimas tarp plaušo ir matricos, plaušas apsaugomas nuo vandens poveikio ir pagerinamos plaušo mechaninès savybès. Pluoštų tiesioginio tempimo bandymais nustatyta, kad silano polimerai perdengia plaušo paviršiuje esančius pažeidimus ir padidina pluošto deformacijų energiją (Zinck et al., 1999; Mader et al., 2004; Rothe et al., 2015). Naujausių mokslinių tyrimų duomenimis, teigiamą ịtaką plaušų savybėms taip pat turi anglies nano vamzdeliais modifikuotos dangos. Panaudojant šias dangas, stiklo pluošto atsparumas tempimui padidejjo iki $50 \%$ net po 7 parų mirkymo $5 \%$ koncentracijos $\mathrm{NaOH}$ šarminiame tirpale $20{ }^{\circ} \mathrm{C}$ temperatūroje (Gao et al., 2007). 


\subsection{Plaušu armuoto smulkiagrūdžio betono ilgaamžiškumas}

\subsubsection{Mechaninių savybių pastovumo vertinimo principai}

Kiekvienos statybinès medžiagos eksploatacinių savybių pastovumas privalo būti ịvertintas ir apibrèžtas. Dèl daugybès sudėtingų fizikinių ir cheminių procesų, kurie vyksta eksploatuojant statybos produktus natūraliomis klimato sąlygomis, jų mechaninès ir vizualinès charakteristikos blogèja. Pagal JAV statybos inžinierių sajungos (ASCE) atliktus skaičiavimus, naujus statinius galima eksploatuoti be techninio aptarnavimo vidutiniškai 18,5 metų (Abanilla 2006). Ironiška, tačiau kiekvienas moderniais laikais pastatytas statinys yra mažiau ilgaamžis negu tie, kurie buvo statyti pagal dviejų tūkstantmečių senumo statybos technologijas, pavyzdžiui Didžioji Sančio Stupa (Indija, 200 m. pr. kr), romėnų Pont du Gard akvedukas (Romos imperija, 19 m. pr. kr.), Romos Panteonas (Romos imperija, 118 m. pr. kr.).

Dispersiškai armuoti betonai - ne išimtis, garantuojanti išskirtinį eksploatacinių savybių pastovumą. Žinių trūkumas apie plaušų korozijos mechanizmus cementinejje matricoje gali nuvesti prie rimtų problemų eksploatuojant statinị. Kadangi stiklo plaušas yra seniausiai ir daugiausiai naudojamas praktikoje, jo korozijos mechanizmai yra ištyrinèti plačiausiai, galima rasti net kai kurių šalių nacionalines projektavimo rekomendacijas. Mokslinèje literatūroje trūksta duomenų apie kitų šiame darbe nagrinèjamų plaušų savybių pastovumo tyrimus. Todèl būtų naudinga išanalizuoti mokslininkų bei inžinierių sukauptą patirtị apie stiklo dispersiškai armuotų cementinių kompozitų eksploatacinių savybių pastovumą bei tyrimo metodus ir šiuos duomenis pritaikyti toliau tyrinejant stiklo plaušo pakaitalus.

Pirmosios rekomendacijos apie stiklo plaušu armuotų kompozitų savybių pastovumą buvo suformuluotos 1956 metais Didžioje Britanijoje, vienos iš seniausiai veikiančių statinių ekspertų kompanijų - Pilkington Bros (1956) (1.8 pav.). İvertinant ilgalaikị stiprumo mažèjimą, pradinè $21 \mathrm{MPa}$ lenkimo stiprumo reikšmé po 28 parų kietèjimo buvo sumažinta $50 \%$. Pritaikius šiai medžiagai 1,75 atsargos koeficientą gautas $6 \mathrm{MPa}$ ilgalaikis lenkimo stiprumas, kuris buvo rekomenduojamas projektuotojams vertinant ilgalaikes apkrovas, pavyzdžiui vejjo. Trumpalaikès stipruminès savybès (po paros, po savaitès) svarbios tik gamybos, transportavimo bei statybos stadijose, todèl vertinant gaminių iškèlimą iš formų, sandèliavimą bei montavimą galima naudoti faktines bandymais gautas betono stiprumines charakteristikas. 


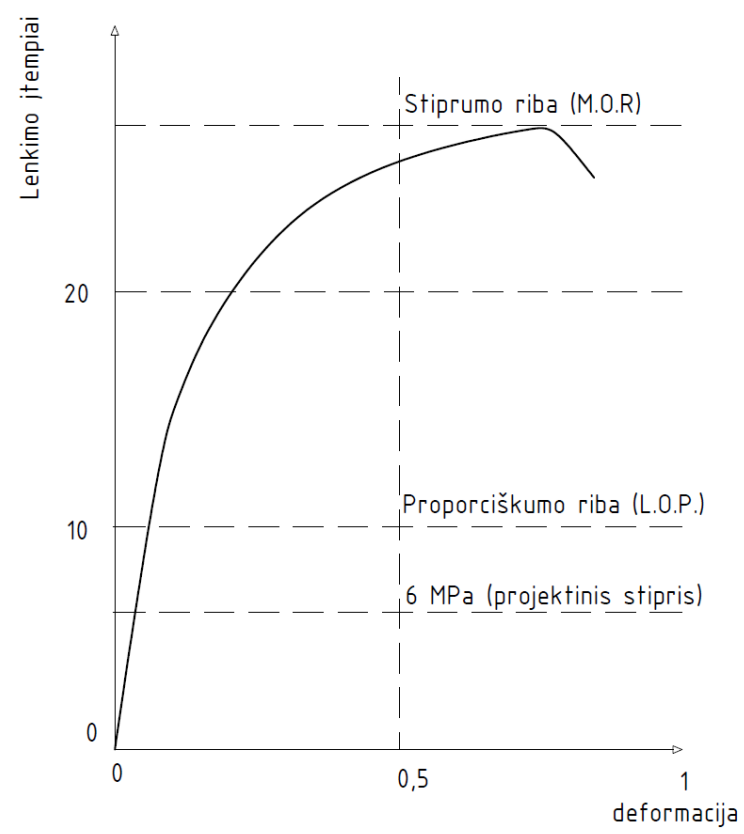

1.8 pav. Ilgalaikis lenkimo stipris pagal Pilkington Bros rekomendacija (1956 metai)

Fig. 1.8. Long term flexural strength according to Pilkington Bros recommendations (year 1956)

Nuo 1975 metų plačiai taikomas ribinių būvių projektavimo metodas, kuris puikiai tinka tokioms statybinėms medžiagoms, kaip plienas ar gelžbetonis, kurios turi aiškias ribas tarp elastinių ir plastinių ribinių būvių. Tačiau tokioms medžiagoms kaip mediena, aliuminis ir stiklo plaušu armuotas betonas ribinių būvių metodiką taikyti sudètinga, kadangi jos neturi aiškios ribos tarp tiesinių ir plastinių deformacijų, todèl kai kurie mokslininkai rekomenduoja naudoti ribinio įtempio projektavimo metodologiją (Guan et al., 2015).

Australijos gelžbetonio gamintojų asociacija skatina projektuotojus naudoti realių bandymų duomenis vertinant stiklo plaušu armuoto betono mechanines savybes, kadangi jos stipriai priklauso nuo mišinio sudeties ir gamybos būdo (1.9 pav.). Purškimo metodu gaminamo betono 28 parų lenkimo stiprio žinomos vertès kinta tarp 21-35 MPa. Eksploatuojant gaminius natūralaus klimato sąlygomis lenkimo stipris palaipsniui mažèja kol nusistovi iki pastovios reikšmės. Anot minètų Australijos rekomendacijų didžiausias ilgalaikis stipris - $17 \mathrm{MPa}$ pasiekiamas su naujo tipo cementinèmis matricomis, pavyzdžiui modifikuojant meta- 
kaolino priedu. Tipinių gamyboje naudojamų betonų ilgalaikis stiprumas Australijos klimato sąlygomis - 13,5 MPa, o Didžiosios Britanijos - 15,0 MPa. Šị skirtumą galima būtų paaiškinti tuo, kad šioms šalims būdingas skirtingo intensyvumo džiovinimo - drèkinimo ciklų poveikis. Prastos kokybės betono mišiniams ir kai trūksta duomenų apie gamybos procesų kokybès kontrolę, siūloma priimti 4,5 MPa ilgalaikị lenkimo stiprị.

Takūs mišiniai su stiklo plaušu pradèti tyrinèti pakankamai neseniai, todèl trūksta duomenų apie jų ilgalaikị stiprumą. Tačiau minètose Australijos betono asociacijos rekomendacijose pateikiama pastaba, kad takaus betono ilgalaikis stiprumas paprastai išlieka artimas ankstyvajam 28 parų, arba kai kuriais atvejais gali šiek tiek padidèti.

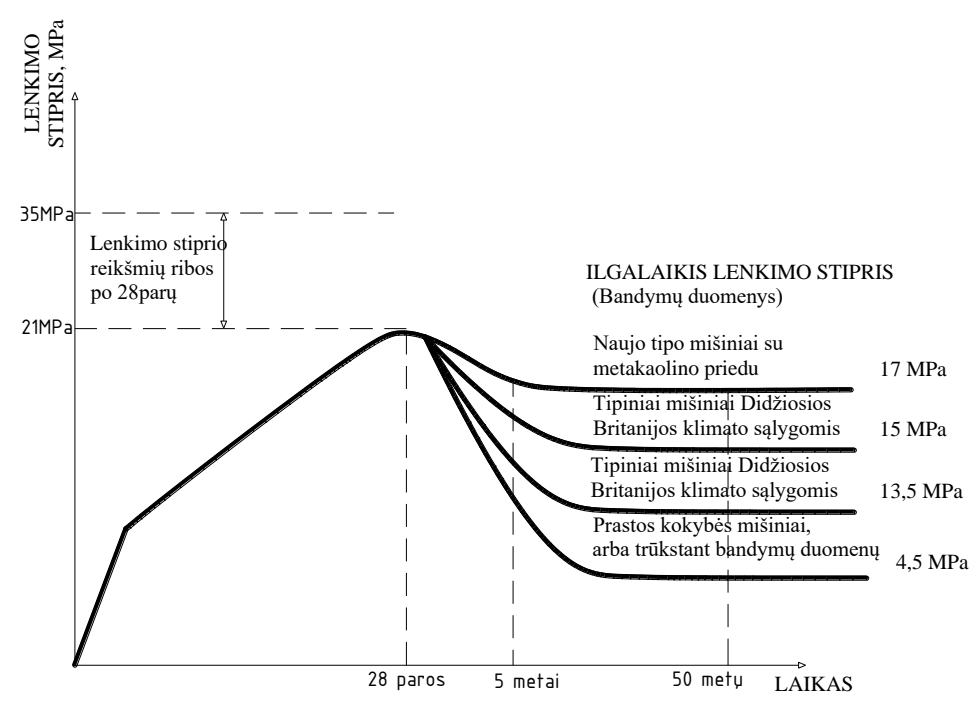

1.9 pav. Ilgalaikis lenkimo stipris purškimo metodu gaminamam stiklo plaušu armuotam betonui pagal Australijos betono gamintojų asociacijos rekomendacijas (2006 metai)

Fig. 1.9. Long term flexural strength for sprayed GRC according to Austalian GRC industry Association reco mmendations (year 2006)

\subsubsection{Mechaninių savybių pastovumo tyrimo metodai}

Pastaruosius 60 metų daugybė mokslininkų tyrinejjo stiklo plaušu armuoto betono korozijos procesus, tačiau vieningos nuomonès šiuo klausimu kol kas nėra. Skaitant ịvairius straispsnius šia tematika, beveik kiekviename galima rasti nuorodą ị Litherland (1981) atliktą tyrimą, kuris iki šiol yra dažnai naudojamas kaip metodas greituoju būdu nustatyti šio kompozito ilgalaikèms mechaninėms charakteristikoms. Surinkęs daugybę empirinių duomenų, Litherland (1981) pasiūlè metodą 
pagrystą bandinių laikymu karštame vandenyje keletą mėnesių. Nepaisant to, kad mokslininkas nepasiūlè teorinio modelio, jam pavyko nustatyti stiprią koreliaciją tarp stiprio mažėjimo ir mirkymo karštame vandenyje laiko. Nustatant kompozito ilgalaikes stiprumines savybes, šis tyrimo metodas daugybę metų buvo laikomas pagrindiniu.

Pirmieji ilgaamžiškumo bandymų duomenys buvo pateiki 1979 metais po 10 metų stebejjimo natūraliomis klimato sąlygomis (Building Research Establishement, 1979). Vèliau Litherland (1981) sukūrè unikalų metodą (1.10 pav.), pagal kuri buvo nustatytas ịvairių pluoštų ilgaamžiškumas cementinejje matricoje (S.I.C. - Strand In Cement test). Empirinių tyrimų duomenys buvo ekstrapoliuoti 100 metų Didžiosios Britanijos klimato sąlygoms, o bandymo metodas buvo nesunkiai pritaikomas praktikoje.

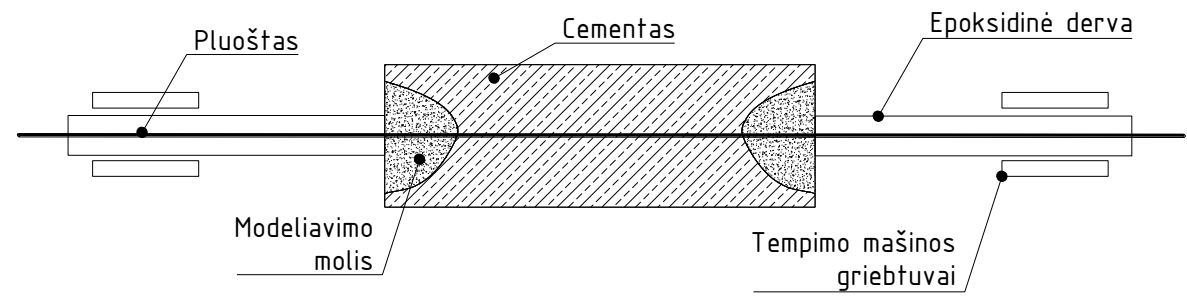

1.10 pav. Pluošto cementinèje matricoje bandymo metodas (SIC testas).

Fig. 1.10. Strand in cement (SIC) test (Litherland 1981)

Abu minèti bandymo metodai paremti bandinių mirkymu vandenyje, kurio temperatūra buvo tarp $4{ }^{\circ} \mathrm{C}$ ir $80^{\circ} \mathrm{C}$ skirtingus laiko intervalus, kurie truko iki 3 metų. Gautus duomenis Litherland atspausdino logaritminèje skalëje ir pastebejo, kad lenkimo stipris didejjant laikui mažèja visoms temperatūroms lygiagrečiomis linijomis nuo pradinès $30 \mathrm{MPa}$ reikšmès iki stabilios $12 \mathrm{MPa}$, kuri reišké ilgalaikị kompozito stiprumą. Gauti pagreitinto bandymo metodo duomenys buvo palyginti su 10 metų stebèjimo rezultatais (Building Research Establishment, 1979) ir padaryta išvada, kad viena para mirkymo $50{ }^{\circ} \mathrm{C}$ temperatūroje atitinka 90 parų eksploatavimo Didžiosios Britanijos natūraliomis klimato sąlygomis.

Tačiau po 1990-uju kai kurie mokslininkai pradejjo abejoti ar šis metodas tinka betonams, kurie turi ịvairių matricos struktūrą modifikuojančių priemaišų. Tokie priedai kaip metakaolinas, silicio mikrodulkès, aukštakrosnių šlakas ar pelenai sužadina sudètingas pucolanines reakcijas aukštose temperatūrose, kurios nèra būdingos eksploatuojant natūraliomis klimato sąlygomis. Purnell P. abejojo standartinių tyrimų tinkamumu modifikuotoms portlandcemenčio matricoms. 
Trijų tipų bandiniai su tipine portlandcemenčio ir modifikuotomis sulfoaliuminatais bei metakaolinu matricomis buvo laikomi $20^{\circ} \mathrm{C}, 38^{\circ} \mathrm{C}$ ir $65^{\circ} \mathrm{C}$ temperatūrose iki vienerių metų. Bandymai parodè, kad lenkimo stiprumo reikšmès po vienerių metų beveik nepakito bandiniams, kurie buvo laikomi $20^{\circ} \mathrm{C}$ ir $38^{\circ} \mathrm{C}$ temperatūrose. Tačiau $65^{\circ} \mathrm{C}$ temperatūroje laikomų bandinių lenkimo stipris sparčiai mažejo. Tipinès portlandcemenčio matricos bandymų duomenys stipriai koreliavo su Litherland gautais rezultatais. Tačiau abi modifikuotos matricos demonstravo labai keistą elgseną, kuomet pirmas 28 paras lenkimo stipris didejo, o po to ėmé staiga mažèti (Purnell et al., 1999). Kiti panašūs tyrimai taip pat parodè panašius neatitikimus su standartiniu Litherland bandymo metodu kai tyrinejjamos aktyviais mineraliniais priedais $\left(\mathrm{SiO}_{2}\right.$ mikrodulkèmis bei metakaolinu) modifikuotos cementinès matricos (Peled 2005; Purnell 2001).

Bartos ir Zhu (1997) pasiūlè naują tyrimų metodą dispersiškai armuotų cementinių kompozitų ilgaamžiškumo vertinimui. Šis metodas pagrịstas Vikerso mikro kietumo bandymu plaušo - matricos kontaktinèje zonoje ir išstumiant plaušo šerdyje esančias gijas. Naudojant $0,7 \mathrm{mN}$ tikslumo prietaisą mikrokietumas buvo matuojamas trijose skirtingose vietose: kontakto zonoje, pačios matricos ir šerdyje esančių plaušelių. Bandymų rezultatai parodè, kad pagal Litherland sendintų bandinių trapumo padidejjimas koreliuoja su mikro kietumo reikšmių didejjimu tiek cementinejje matricoje tiek pačiame plauše. Standartinėms portlandcemenčio matricoms gautas mikro kietumo reikšmių padidèjimas: $60 \%$ pačios matricos, $10 \%$ kontakto zonoje ir $140 \%$ plaušo šerdyje. Šiu mokslininkų atlikti tyrimai parode, kad trintis tarp pluošto viduje esančių gijų padideja veikiant matricos senejjimo procesams.

Prabėgus daugybei metų nuo šių kompozitų mokslinių tyrimų pradžios, labai mažai dėmesio buvo skiriama atsparumo užšaldymo ir atšildymo ciklų poveikio tyrimams. Tai gali būti susiję su tuo, kad šie kompozitai yra daugiausiai naudojami šilto - drègno klimato zonose, tokiose kaip Austalija, Didžioji Britanija, Kinija, Saudo Arabija. Europos standartas LST EN 15191, kuriame ịvardijami reikalavimai stiklo plaušu armuoto betono eksploatacinèms charakteristikoms siūlo atsparumą šalčiui bandyti pagal paviršinio šaldymo metodą, detaliau aprašytą LST EN 13198. Bandymas atliekamas užliejus bandinių paviršių vandeniu arba $3 \%$ $\mathrm{NaCl}$ tirpalu ir veikiant užšaldymo ir atšildymo ciklais temperatūrai svyruojant tarp $-20{ }^{\circ} \mathrm{C}$ ir $+20{ }^{\circ} \mathrm{C}$, kai vieno pilno ciklo trukmé yra 24 valandos. Bandymo metu fiksuojami masès nuostoliai nuo bandinių paviršiaus ir bet kokie vizualinio pobūdžio pažeidimai (suaižèjimai, atpleišèjimai). Vienintelis mokslinis tyrimas apie šio kompozito atsparumą šalčiui atliktas Enfedaque (2012) pagal minètą paviršinio šaldymo metodiką. Po 50 užšaldymo ir atšildymo ciklų klimatinejje kameroje standartinès portalandcemenčio matricos bandiniai prarado iki $40 \%$ pradinio lenkimo stiprio ir iki $80 \%$ pradinès deformacijos, kompozitui tampant trapesne medžiaga su mažesniu lenkimo stipriu. 
Realiomis klimato sąlygomis eksploatuojami gaminiai yra labiau veikiami džiovinimo/drèkinimo negu pastovaus mirkymo vandenyje. Toks bandymo metodas yra aprašytas standarte LST EN 1170-8, pagal kuri nustatomas ilgalaikis 10-20 metu amžiaus stiklo plaušu armuoto kompozito lenkimo stipris kuomet nagrinejjamai klimato zonai nèra būdingi užšaldymo ir atšildymo ciklai. Bandymas reikalauja klimatinès kameros su temperatūriniu režimu tarp $20^{\circ} \mathrm{C}$ ir $70{ }^{\circ} \mathrm{C}$, automatiniu drèkinimu ir ventiliavimu. Vienas pilnas drèkinimo/džiovinimo ciklas tęsiasi 48 valandas ir ji sudaro dvi fazès: mirkymas $20^{\circ} \mathrm{C}$ temperatūroje ir džiovinimas prie $70^{\circ} \mathrm{C}$. Nepaisant to, kad šis tyrimo metodas yra artimesnis realaus klimato poveikiui, labai mažai mokslininkų turi galimybę jị pritaikyti ir vietoje to naudoja klasikini Litherland (1981) išlaikymo karštame vandenyje metodą.

Enfedaque (2012) palygino dviem skirtingais metodais (paviršiniu šaldymu/ atšildymu ir drèkinimu/džiovinimu) gautus lenkimo stiprio duomenis. Nustatyta, kad tipinès matricos bandiniai po 50 užšaldymo ir atšildymo ciklų prarado tokị pat kiekị pradinio stiprumo, kaip po 200 drékinimo/džiovinimo ciklų. Galima daryti prielaidą, kad stiklo plaušu armuoto cementinio kompozito ilgalaikị stiprumą galima nustatyti naudojant paviršinio užšaldymo ir atšildymo bandymo metodą vietoje mirkymo karštame vandenyje arba džiovinimo drèkinimo pagal LST EN 1170-8, kuris paprastai užtrunka žymiai daugiau laiko (iki 8 kartų), gaunant tuos pačius duomenis.

\subsubsection{Stiklo plaušu armuoto betono korozijos procesai}

Stiklo sudètyje esantys oksidai yra nestabilūs šarminèje terpèje dèl sudètingų hidratacijos procesų. $\mathrm{SiO}_{2}$ migracija ị šarminị tirpalą yra lètas procesas, tačiau labai suintensyvejja, kai $\mathrm{pH}$ viršija 10 . Cementinès matricos agresyvioje šarminejje terpeje, kur pH siekia 12 pirmieji nuo stiklo paviršiaus atskyla natrio jonai, paskui kuriuos seka ir $\mathrm{Si}-\mathrm{O}-\mathrm{Si}$ struktūros, kurios yra ardomos hidroksilo $\mathrm{OH}^{-}$jonų (Paul, 1977):

$$
\begin{gathered}
\mathrm{Si}-\mathrm{O}-\mathrm{Si}-\mathrm{O}^{-} \mathrm{Na}^{+}+\mathrm{H}_{2} \mathrm{O} \rightarrow \mathrm{Si}-\mathrm{O}-\mathrm{Si}-\mathrm{OH}+\mathrm{NaOH} \\
\mathrm{Si}-\mathrm{O}-\mathrm{Si}-\mathrm{OH}+\mathrm{OH}^{-} \rightarrow \mathrm{Si}-\mathrm{OH}+\mathrm{O}^{-}-\mathrm{Si}-\mathrm{OH} .
\end{gathered}
$$

Ilgą laiką buvo manoma, kad pagrindinė stiprio mažèjimo priežastis yra cheminès reakcijos stiklo plaušo ir cementinès matricos kontaktinejje zonoje (1.11 pav.). Tačiau mokslininkų atlikti empiriniai tyrimai šią prielaidą paneigè, nes atlikus ilgaamžiškumo bandymus pagal Litherland (1981) ir imant mėginius iš eksploatuojamų pastatų reikšmingų cheminių reakcijų požymių kontakto zonoje ar plaušo skerspjūvio sumažèjimo nepastebèta (Bentur et al., 1985; Cohen et al., 1985; Diamond et al., 1985; Jaras et al., 1975). Remdamasis šių tyrimų duomenimis, Purnell (2001) metais pasiūlè stiklo plaušu armuoto betono korozijos teorini 
modelị, pagrịstą nano ịtrūkimų atsiradimu plaušo paviršiuje. Šis reiškinys mokslinejje literatūroje yra vadinamas statiniu nuovargiu ir apibūdinamas kaip laipsniškas $\mathrm{SiO}_{2}$ ryšių trūkinejjimas ties plyšio viršūne veikiant statinei apkrovai (1.12 pav.)

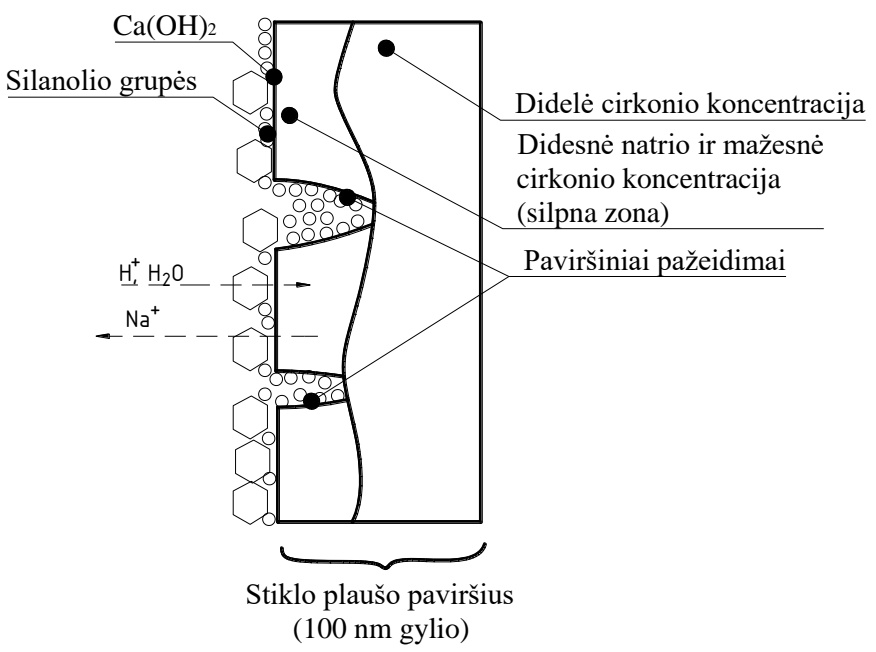

1.11 pav. Cheminiai procesai, vykstantys stiklo plaušo paviršiuje veikiant šarminiam tirpalui (Orlovsky et al., 2005)

Fig. 1.11. Chemical processes on the glass filament surface

(Orlovsky et al., 2005)

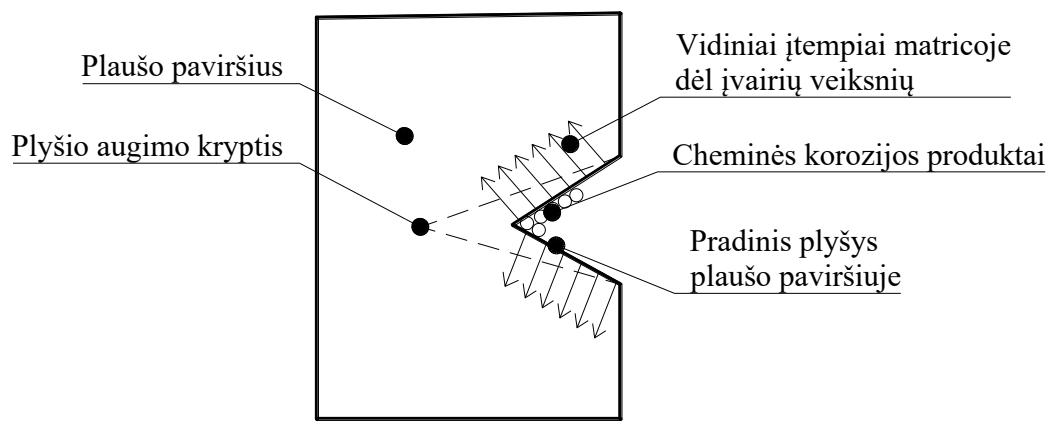

1.12 pav. Plyšio stiklo plaušo paviršiuje didejjimas dèl matricoje susidarančių vidinių ittempių (Purnell, 2005)

Fig. 1.12. Fiber surface flaw growth due to inner stress (Purnell, 2005) 
Statinio nuovargio procesas priklauso nuo tokių faktorių kaip, stiklo plaušo cheminè sudètis, matricos $\mathrm{pH}$, vidinių įtempių dydžio ir temperatūros. Dèl statinio nuovargio stiklui būdingas staigus suirimas veikiant ịtempiams, kurie yra mažesni negu būdingi pradinių savybių medžiagai. Žinodamas, kad šio kompozito korozijos reakcijos greitis priklauso nuo temperatūros, Purnell (2005) prognozuoja ilgalaikị stiprị $S$ priklausomai nuo laiko $t$ pagal klasikinę Artenijaus priklausomybę ir remdamasis mokslininkų atliktais ilgaamžiškumo bandymais:

$$
S=\frac{1}{\sqrt{1+k_{0} e^{\left(-\frac{\Delta G}{R T}\right)} \cdot t}},
$$

čia, $t$ - kompozito amžius, paromis; $T$-aplinkos temperatūra, $\mathrm{K} ; R$ - universalioji dujų konstanta, $\mathrm{J} \cdot \mathrm{mol}^{-1} \cdot \mathrm{K}^{-1} ; \Delta G$ - korozijos proceso aktyvacijos energija $\mathrm{J} / \mathrm{mol}$, $k_{0}$ - prie-eksponentinis koeficientas stiprumo sumažejimui.

Būtina paminèti, kad $k_{0}$ yra unikalus dydis būdingas konkrečiai sudęčiai ir veikiančiai temperatūrai. Aktyvacijos energija tipinei portlandcemenčio matricai $\Delta G=89-93 \mathrm{~kJ} / \mathrm{mol}^{-1}$. Tolimesni mokslininku atlikti tyrimai su modifikuotomis portlandcemenčio matricomis parodè, kad sudètims turinčioms metakaolino ar sulfoaliuminatų dẻl ko sumažeja $\mathrm{Ca}(\mathrm{OH})_{2}$ kiekis, būdinga korozijos reakcijos aktyvacijos energija $\Delta G=57-59 \mathrm{~kJ} / \mathrm{mol}^{-1}$, kas yra žymiai mažiau nei tipinei portlandcemenčio matricai. Pagal 1.1 formulę, cementinè matrica su mažesne aktyvacijos energija turès didesnị ilgaamžiškumą (Purnell et al., 2008).

Plaušo ir cementinès matricos sukibimas gali būti nustatomas pluošto ištraukimo būdu, bandant tą pati pluoštą, iš kurio yra pagamintas stiklo plaušas. Turint omenyje, kad pluoštą ar plaušą sudaro daugybe pavienių gijų, tik išorinès, kurios turi tiesioginị kontaktą su matrica, perima didžiausią dalį tempimo įtempių. Giliau esančioms gijoms įtempiai perduodami tik trinties jègų pagalba. Laws (1986) atliko stiklo pluošto ištraukimo bandymus su ịvairiais pluošto inkaravimo ilgiais cementinejje matricoje, nuo $1,5 \mathrm{~mm}$ iki $10 \mathrm{~mm}$. Pluoštas buvo sudarytas iš 200 pavienių gijų, kurių kiekvienos diametras 12,5 $\mu \mathrm{m}$. Bandymų rezultatai parodė, kad ištraukimo jëga vienam plaušui lygi $0,4 \mathrm{kN}$, kai inkaravimo ilgis $10 \mathrm{~mm}$. Taip pat ištraukimo jèga bègant laikui padidèjo, kai bandiniai buvo laikomi $20^{\circ} \mathrm{C}$ vandenyje. Butler (2009) skenuojančiu mikroskopu tyrinejjo iš cementinès matricos ištraukto stiklo plaušo paviršių. Tyrimai parodė, kad pagrindinè blogo sukibimo su cementine matrica priežastis yra trapios portlandito fazès, kurios dominuoja portandcemenčio matricoje. Geresnis plaušo sukibimas buvo nustatytas betono sudètyse su mažesniu cemento klinkerio kiekiu ir panaudojus pucolaninius priedus, kurie sumažina cementinès matricos šarmingumą.

Mokslininkai vieningai sutaria, kad plaušo kontakto zonoje augantys $\mathrm{Ca}(\mathrm{OH})_{2}$ kristalai turi neigiamą ịtaką kompozito ilgaamžiškumui. Mikroskopiniai tyrimai parode, $\mathrm{kad} \mathrm{Ca}(\mathrm{OH})_{2}$ kristalams būdingos aštriabriaunès formos, todèl vykstant hidratacijos procesams ir didejant vidiniams įtempiams matricoje dèl 
kristalų augimo plaušo paviršiuje gali atsirasti pažeidimų ir toliau dèl prieš tai aptarto statinio nuovargio reiškinio kompozito ilgalaikis stiprumas sumažeja (Huijun et al., 2013; Purnell et al., 1999; Mills et al., 1981).

Smulkiagrūdžiuose cementiniuose kompozituose paprastai sunaudojama 3-4 kartus daugiau cemento, negu ịprastiniuose betonuose. Taip suformuojama labai tanki kapiliarų sistema, per kurią gali migruoti drègmè. Džiūvimas - brinkimas gali bet kurioje medžiagoje sukelti vidinių įtempių svyravimus, dèl kurių medžiaga gali supleišèti. Laboratorijos sąlygomis nustatyta, kad po 96 parų džiovinimo - brinkimo bandymų stiklo plaušu armuoto cementinio kompozito maksimalios susitraukimo - brinkimo deformacijos yra tarp 0,08-0,1\% (Theodorakopoulos, 1995). Turkijoje buvo atliktas tyrimas matuojant realiu gabaritu elementų deformacijas, laikant juos natūraliomis klimato sąlygomis 5 metus, kuomet užfiksuoti temperatūrų svyravimai buvo tarp $-7^{\circ} \mathrm{C}$ ir $37^{\circ} \mathrm{C}$. Prie šių sąlygų nustatytos didžiausios susitraukimo deformacijos sieke $0,25 \%$, o brinkimo $0,18 \%$. Bandinių paviršiuje įtrūkimų nebuvo užfiksuota (Ispir, 2015). Correia (2005) tyrinèjo

20 metų senumo sutrūkinèjusị pastato fasadą. Nustatyta, kad trūkiai stiklo plaušu armuoto cementinio kompozito fasadinèse plokštèse atsirado dèl temperatūrinių deformacijų, kurios sukèlè vidinius tempimo ịtempius, siekiančius 4-6 MPa dèl per daug standžiai ịrengtų sieninių elementų tvirtinimo mazgų. Tuo tarpu pačio betono tempimo stipris siekè vos 2,5 MPa dẻl to, kad gamintojas panaudojo šarmams neatsparų stiklo plaušą.

Cementinio akmens karbonizacija yra labai lètas procesas kuomet $\mathrm{Ca}(\mathrm{OH})_{2}$ reaguoja su atmosferiniu $\mathrm{CO}_{2}$ taip suformuodami naują mineralą $\mathrm{CaCO}_{3}$, vadinamą kalcitu, kuris yra stipresnis už $\mathrm{Ca}(\mathrm{OH})_{2}$ ir sąlygoja betono gniuždymo stiprio padidejjimą. Vykstant šiai reakcijai, betono $\mathrm{pH}$ sumažeja ir pranyksta plieninę armatūrą nuo korozijos sauganti šarminè aplinka. Tačiau stiklo plaušu armuotiems cementiniams kompozitams karbonizacija yra teigiamas procesas, nes sumažèja $\mathrm{Ca}(\mathrm{OH})_{2}$ kristalų kiekis, kurie žalingai veikia plaušo paviršių. Augantys $\mathrm{CaCO}_{3}$ kristalai užpildo poras, taip sutankindami cementinę matricą, kurios stiprumas padidèja iki $70 \%$ lyginant su pirmine būsena. Purnell (2001) tyrinejjo ypač - kritinès karbonizacijos $\left(\mathrm{scCO}_{2}\right)$ poveikị stiklo plaušu armuoto betono mechaninèms savybèms. Bandiniai buvo veikiami 24 valandas didelès koncentracijos $\mathrm{CO}_{2}$ dujomis esant $10 \mathrm{MPa}$ slègiui ir $59^{\circ} \mathrm{C}$ temperatūrai, po to mirkomi 56 paras karštame vandenyje pagal Litherland (1981) metodą. Karbonizacija padidino cementinès matricos stiprị iki $70 \%$, plaušo - matricos sukibimą 3 kartus ir bandiniai atlikus lenkimo bandymus nerode jokių trapumo požymių (1.13 pav.). 


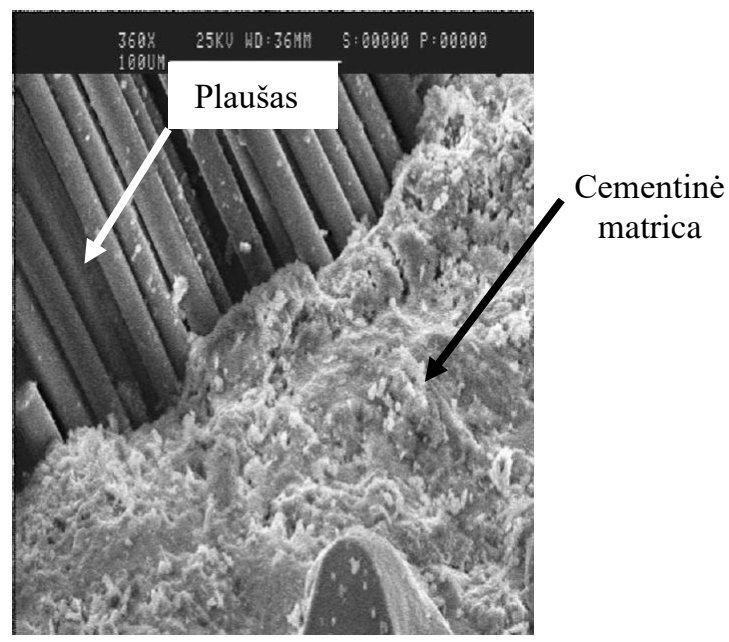

1.13 pav. Skenuojančio elektroninio mikroskopo nuotrauka: 28 paras karbonizuotas bandinys (Purnell et al., 2001)

Fig. 1.13. Scanning electron micrograph: aged (28days) carbonated sample

(Purnell et al., 2001)

\subsubsection{Korozijos procesų vertinimas pagal betono lenkimo deformacijų energiją}

Dèl betone vykstančių ịvairių korozijos procesų keičiasi medžiagos stipruminės charakteristikos. Betoninių ir gelžbetoninių elementų stiprumui charakterizuoti dažniausiai naudojamas lenkimo, gniuždymo bei tempimo stipris. Tačiau tokioms pseudo-plastinėms medžiagoms kaip dispersiškai armuoti betonai šių charakteristikų neužtenka, kad galima būtų ịvertinti medžiagos darbą iki visiško suardymo. Šiai medžiagai būdingos didelès plastinès deformacijos, todèl tikslinga naudoti lenkimo deformacijų energiją vertinant mechaninių savybių pakitimus dẻl korozijos procesų poveikio.

Lenkimo metu dispersiškai armuoto betono paviršiuje mikroplyšiai auga tol, kol priešais plyšius atsiranda didesnio stiprumo sritis, galinti atlaikyti koncentruotus įtempius. Šioje srityje gali būti didesnis plaušelių kiekis, nei šalia esančių. Tokiu atveju, vienų plyšių augimas sustoja, o kitų esančių šalia plotis pradeda didèti. Atsirandant naujiems plyšiams ir didejjant jų pločiui, didejja apkrova, kurią atlaiko bandinys. Pasiekus bandinio stiprumą, lūžis įvyksta ties silpniausiu mikroplyšiu, ties kuriuo bandinys padalinamas ị dvi dalis (Enfedaque et al., 2010).

Dẻl nepakankamo lenkimo stiprio bandinyje gali atsirasti įtrūkimų, tačiau pagal irimo mechanikos teoriją, trapų suirimą dažniausiai lemia nepakankamas atsparumas suardymui. Mokslininkų nustatyta, kad stiklo plaušu armuoto betono atsparumas suardymui mažèja didejjant bandinio amžiui, tai yra lenkimo deformacijų 
kreive igauna vis didesnị nuolydị. Šio betono suirimo pobūdis yra panašus ị trapaus betono, išskyrus tai, kad papildomo atsparumo suardymui suteikia plaušelių ištraukimui iš cementinès matricos reikalingas darbas. Todèl iš principo dispersiškai armuoto betono suirimas nagrinejjamas atsižvelgiant ị betono irimo mechanikos dèsnius (Cheng et al., 2019).

Hillerborg (1976) pasiūlytas virtualaus plyšio modelis (FCM) apibūdina trūkių betone atsiradimą ir plètrą. $1985 \mathrm{~m}$. Tarptautinè statybinių medžiagų, sistemų ir konstrukcijų laboratorijų ir ekspertų sajunga (RILEM) prièmė Hillerborg pasiūlytą eksperimentinį metodą kaip standartinę betono suardymo energijos bandymų metodiką. Visais atvejais rekomenduojamas keturių taškų lenkimo bandymas. $\breve{S} i$ keturių taškų apkrova sukelia vienodus maksimalius įtempius bandinio viduriniame trečdalyje, skirtingai nei trijų atramų schemoje, kai maksimalūs įtempiai gaunami tik jègos pridejjimo taške. Bandiniui suardyti reikalingą darbą sudaro lenkimo mašinos atliktas darbas ir papildomas darbas nuo bandinio savojo svorio. Bendras suardymo energijos kiekis yra:

$$
W=W_{0}+W_{1},
$$

$W_{0}$ yra plotas po lenkimo deformacijų kreive. $W_{1}$ yra papildomas darbas nuo bandinio svorio. Sunku tiksliai apskaičiuoti bandinio svorio atliktą darbą. Kadangi papildomas darbas $\left(W_{1}\right)$ yra daug kartų mažesnis nei mašinos atliekamas darbas $\left(W_{0}\right)$, papildomas darbas gali būti apytiksliai išreikštas bandinio svorio $(m g)$ ir didžiausios deformacijos sandauga $\left(v_{\max }\right)$. Didžiausia deformacija užfiksuojama tuomet, kai bandinio liekamasis stiprumas pasiekia $20 \%$ maksimalios lenkimo stiprio reikšmès. Taigi, suardymo energiją galima išreikšti:

$$
W=W_{0}+m g v_{\max } .
$$

RILEM metodas pagrịstas bandinio suardymo darbo principu. Daroma prielaida, kad išsklaidyta elastinè deformacijos energija nuteka ị lūžio zoną, kai ịvyksta galutinis suardymas, tai yra išorinès jègos atliktas darbas yra pilnai panaudojamas plyšio pločiui didèti (Zhang et al., 2008). Išorinių jègų atliktas darbas galiausiai transformuojamas i plaušu armuoto betono suardymo energiją. RILEM rekomenduoja lenkimo deformacijų energiją skaičiuoti pagal šią formulę:

$$
G_{f}=\frac{W_{0}+m g v_{\max }}{A_{\text {lig }}},
$$

čia: $G_{f}$ - lenkimo deformacijų (bandinio suardymo energija), $\mathrm{Nm}^{-1} ; W_{0}$ - bandymų mašinos atliktas darbas, apskaičiuojamas kaip plotas po lenkimo deformacijų kreive, Nm; $m g$ - bandinio svoris, N; $v_{\max }$ - deformacija prie $20 \%$ maksimalios lenkimo stiprio reikšmés; $A_{\text {lig }}$ - bandinio plyšio plotas, $\mathrm{m}^{2}$. 


\subsection{Pirmojo skyriaus išvados ir disertacijos uždavinių formulavimas}

Atlikus literatūros analizę paaiškejjo, kad:

1. Dispersinis betono armavimas stiklo, bazalto, aglies bei polivinilo alkoholio plaušais padidina betono lenkimo stiprị ir standumą.

2. Kadangi smulkiagrūdžiams betono mišiniams yra naudojamas labai mažas vandens kiekis, o sudètyje yra daug smulkiujų dalelių, ịprasti betono maišymo būdai nèra tinkami, nes neužtenka energijos permaišyti dideliam kiekiui smulkių dalelių ir gauti reikiamą mišinio konsistenciją. Todèl tokio betono gamyboje dažniausiai naudojamas intensyvaus maišymo metodas, kuomet maišyklès mentès sukasi iki 1500 aps./min greičiu.

3. Seniausiai naudojamas gaminių formavimo būdas panaudojant plaušu armuotą betoną yra purškimo metodas. Naudojant didelio efektyvumo plastifikuojančius priedus galima sukurti takius apdailinio betono mišinius su dispersiniu armavimu.

4. Apdailinių plonasienių betono elementų gamybai iki šiol dažniausiai buvo naudojamas šarmams atsparus stiklo plaušas, tačiau tobulëjant pluoštu gamybos technologijoms tikslinga būtų ieškoti galimybių stiklą pakeisti kitais plaušais.

5. Stiklo plaušą cementinèje matricoje veikia sudètingi korozijos procesai, dèl kurių laikui bėgant betono kompozitas iš pseudo-plastiškos medžiagos tampa trapia ir mažèja jo lenkimo stiprumas bei lenkimo deformacijų energija.

6. Siekiant cementinejje matricoje sumažinti šarminių portlandito mineralų, sukeliančių žalingus korozijos procesus stiklo plaušo paviršiuje kiekị, galima panaudoti aktyvius mineralinius priedus, kurie modifikuoja cementinio akmens mikrostruktūrą.

Siekiant sukurti dispersiškai armuotą betoną, tinkamą surenkamụjų sieninių elementų gamybai, kai gaminiai eksploatuojami agresyviomis Baltijos regiono klimato sąlygomis, reikia spręsti šiuos uždavinius:

1. Parinkti žaliavas ir jų proporcijas apdailinio betono kompozitui surenkamujų sieninių elementų gamyboje, kurios užtikrintų gaminio atsparumą trapiam suirimui ir pleišèjimui.

2. Nustatyti stiklo, bazalto, anglies ir polivinilo alkoholio plaušų poveiki plonasienių gaminių apdailinio betono technologinèms bei mechaninėms savybėms kai betono mišiniai ruošiami intensyvaus maišymo būdu. 
3. Nustatyti kvarcinio smèlio, granito atsijų bei ịprastinio žvyro karjerų smèlio užpildų dalelių formos poveikị dispersiškai armuoto smulkiagrūdžio betono konsistencijai bei segregacijai.

4. Nustatyti $\mathrm{SiO}_{2}$ mikrodulkių ir metakaolino mineralinių priedų poveikị dispersiškai armuoto betono atsparumui cikliškam užšaldymui ir atšildymui, vertinant betono apdailinio paviršiaus defektus - atskilusio cementinio akmens kiekị ir lenkimo deformacijų energijos pokyčius, kai numatoma gaminio eksploatavimo trukmè - ne mažiau 20 metų.

5. Ištirti plaušo paviršiaus struktūros pokyčius dèl užšaldymo ir atšildymo ciklų poveikio, kai cementinè matrica modifikuojama $\mathrm{SiO}_{2}$ mikrodulkių ir metakaolino aktyviais mineraliniais priedais. 



\section{2}

\section{Kompozitui sukurti naudotos medžiagos ir tyrimo metodai}

Šiame skyriuje aprašomos moksliniame tiriamajame darbe naudotos medžiagos bei jų savybès. Pateiktos tyrinètų betono mišinių sudètys, aprašytas pasirinktas betono maišymo procesas ir bandinių formavimas. Aptariami tyrimo metodai bei naudota laboratorinè ịranga.

Skyriaus tematika paskelbti septyni autoriaus straipsniai (Moceikis et al., 2017, 2018a, 2018b, 2018c, 2019a, 2019b, 2020).

\subsection{Naudotos medžiagos}

Šiame tiriamajame darbe pasirinktos medžiagos, užtikrinančios geras dispersiškai armuotų betono mišinių technologines charakteristikas ir kompozitų mechanines savybes. Technologinès charakteristikos apibūdinamos mišinio konsistencijos parametrais ir maža segregacija, o esminès mechaninès savybès - lenkimo stipriu ir lenkimo deformacijų energija.

Stiklo, bazalto, anglies ir polivinilo alkoholio plaušams būdingas žymiai didesnis tempimo stipris ir deformacijų modulis negu cementinès matricos. Remiantis literatūros analize, pasirinktas stiklo plaušo kiekis $-2,9 \%$ nuo sausų medžiagų 
masès, kuris užtikrina gerą mišinio konsistenciją ir suteikia kompozitui didelị lenkimo stiprị $(>10 \mathrm{MPa})$. Kitų plaušų proporcijos taip pat parinktos atsižvelgiant ị šias savybes.

Kvarcinio smėlio užpildas užtikrina gerą mišinio konsistenciją dėl vyraujančių apvalios formos dalelių. Tačiau dèl šio užpildo ribotų išteklių šiame darbe taip pat buvo panaudotas Lietuvos žvyro karjerų ịprastinis smèlis ir nerūdinių medžiagų gamybos atlieka - granito atsijos. Pasirinktas užpildo ir rišiklio santykis (1:1) užtikrina didelị cementinès matricos tankị (> $\left.2000 \mathrm{~kg} / \mathrm{m}^{3}\right)$, kuriam didejjant atitinkamai gerèja ir betono mechaninès savybès.

Šiuolaikiniai gamybos procesai reikalauja didelio ankstyvojo stiprio po 20 valandų išformuojant gaminį. Todèl pasirinktas greitai kietejantis CEM I 52,5R klasės portlandcementis, kuris modifikuojamas aktyviais $\mathrm{SiO}_{2}$ mikrodulkių ir metakaolino mineraliniais priedais, kuriems būdingas didelis amorfinio $\mathrm{SiO}_{2}$ kiekis. Didelis šių priedų kiekis ( $>10 \%$ ) betono mišinyje gali neigiamai paveikti betono ankstyvaji stiprị, todèl pasirinkta jų naudoti iki 7,5 \% nuo cemento masès.

Atliekant tyrimus visoms betono mišinių sudètims buvo panaudotas vienodų charakteristikų portlandcementis CEM I 52,5R, gaminamas pagal standarto LST EN 197-1: 2011 reikalavimus. Gamintojo deklaruojama cheminè ir mineraloginè sudètis pateikta 2.1 ir 2.2 lentelèse.

2.1 lentelè. Portlandcemenčio CEM I 52,5R cheminè sudètis, \%

Table 2.1. Chemical composition of Portlandcement CEM I 52,5R, \%

\begin{tabular}{|c|c|l|l|l|l|l|l|l|c|}
\hline $\mathrm{CaO}$ & $\mathrm{SiO}_{2}$ & $\mathrm{Al}_{2} \mathrm{O}_{3}$ & $\mathrm{Fe}_{2} \mathrm{O}_{3}$ & $\mathrm{MgO}$ & $\mathrm{SO}_{3}$ & $\mathrm{~K}_{2} \mathrm{O}$ & $\mathrm{Na}_{2} \mathrm{O}$ & $\mathrm{Na}_{2} \mathrm{O}_{\text {eq }}$ & $\mathrm{Cr}$ \\
\hline 63,99 & 19,84 & 5,24 & 2,99 & 1,55 & 3,05 & 0,78 & 0,25 & 0,76 & 0,062 \\
\hline
\end{tabular}

2.2 lentelè. Portlandcemenčio CEM I 52,5R mineraloginè sudètis, \%

Table 2.2. Mineral composition of Portlandcement CEM I 52,5R, \%

\begin{tabular}{|c|c|c|c|}
\hline $\mathrm{C}_{3} \mathrm{~S}$ & $\mathrm{C}_{2} \mathrm{~S}$ & $\mathrm{C}_{3} \mathrm{~A}$ & $\mathrm{C}_{4} \mathrm{AF}$ \\
\hline 53,56 & 17,23 & 1,43 & 10,4 \\
\hline
\end{tabular}

Kadangi rišiklio dalelių dydis turi didelị poveikị mišinių konsistencijai ir stipruminèms savybėms, buvo nustatytas portlandcemenčio dalelių pasiskirstymas pagal dydị, naudojant lazerinį kietujų dalelių analizatorių CILAS 1090 Liquid, kuris pateiktas 2.1 paveiksle. 


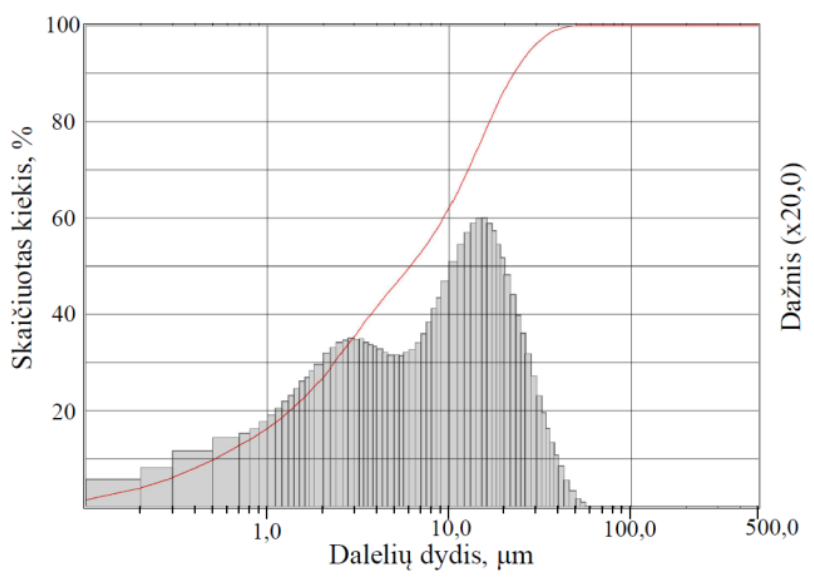

2.1 pav. Portlandcemenčio CEM I 52,5R dalelių pasiskirstymas pagal dydị

Fig. 2.1. Particle size distribution of Portlandcement CEM I 52,5R

Tyrimuose buvo naudojami tik smulkūs užpildai, kurių didžiausios dalelès $d_{\max }=2 \mathrm{~mm}$. Pasirinkti keli skirtingos granuliometrijos ir kilmès užpildai: natūralus kvarcinis smèlis $\left(d_{\max }=1,25 \mathrm{~mm}\right)$, granito atsijos $\left(d_{\max }=2 \mathrm{~mm}\right)$, natūralus žvirgždo karjerų smèlis $\left(d_{\max }=2 \mathrm{~mm}\right)$. Granuliometrinès sudètys nustatytos pagal standartą LST EN12620:2003+A1:2008 naudojant standartinį sietų rinkinị betono užpildams $(63 \mu \mathrm{m} ; 125 \mu \mathrm{m} ; 250 \mu \mathrm{m} ; 500 \mu \mathrm{m} ; 1 \mathrm{~mm} ; 2 \mathrm{~mm} ; 4 \mathrm{~mm})$. Užpildų granuliometrinès kreivès pateiktos 2.2 paveiksle.

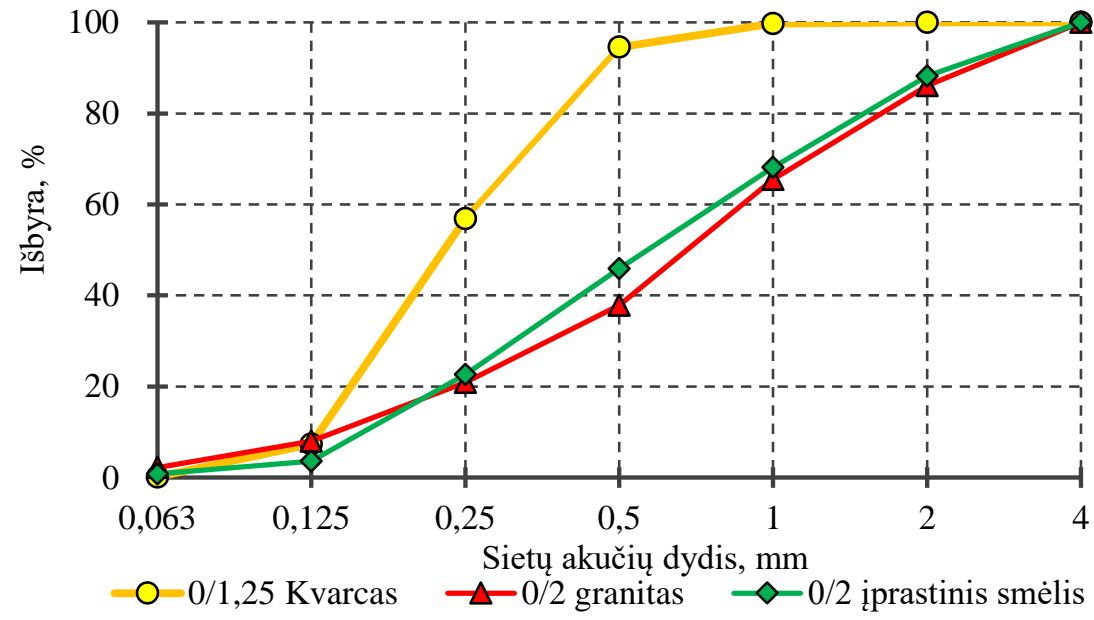

2.2 pav. Užpildų granuliometrinès kreivès

Fig. 2.2. Particle size distribution of aggregates 
Cementinès matricos struktūros modifikavimui parinkti priedai, kurie yra dažnai naudojami inžinerinèje praktikoje, siekiant pagerinti ịvairias apdailinių betonų savybes. Panaudoti aktyvūs mineraliniai užpildai miltelių pavidale $-\mathrm{SiO}_{2}$ mikrodulkès ir metakaolinas, kurių dalelių konglomeratų pasiskirstymas pagal dydį nustatytas lazeriniu analizatoriumi CILAS 1090 Liquid ir pateiktas 2.3 ir 2.4 paveiksluose. Dalelių forma bei pavienių dalelių dydis nustatyta skenuojančiu elektroniniu mikroskopu bei pateiktas 2.5 ir 2.6 paveiksluose.

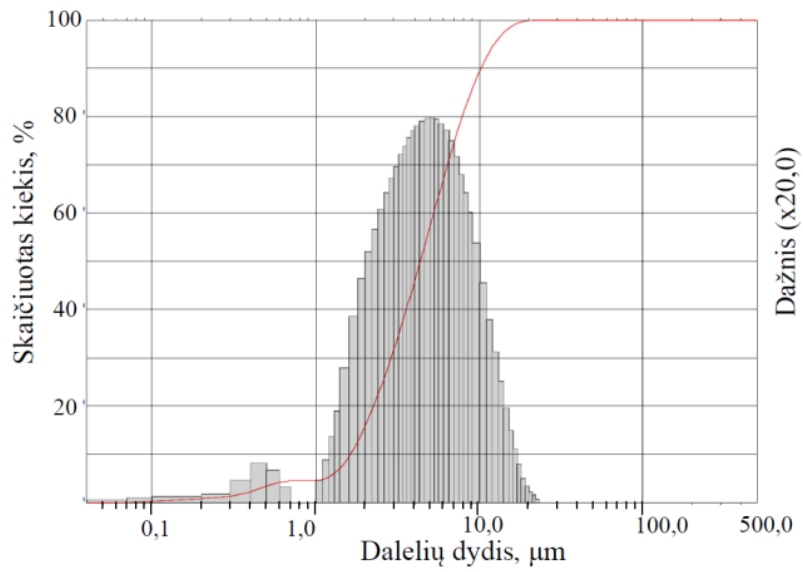

2.3 pav. $\mathrm{SiO}_{2}$ mikrodulkių dalelių konglomeratų pasiskirstymas pagal dydį

Fig. 2.3. Particle konglomerates size distribution of silica fume

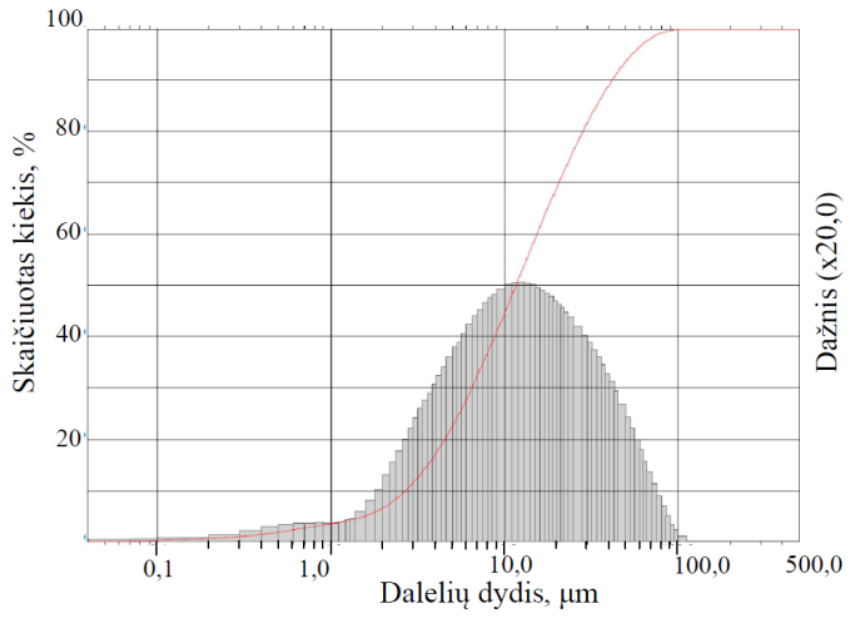

2.4 pav. Metakaolino dalelių konglomeratų pasiskirstymas pagal dydị

Fig. 2.4. Particle konglomerates size distribution of metakaolin 


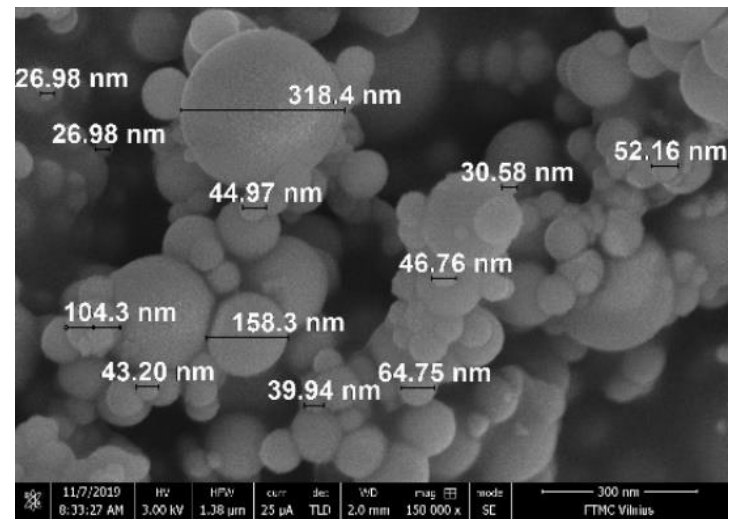

2.5 pav. $\mathrm{SiO}_{2}$ mikrodulkių SEM nuotrauka (didinimas 150000 kartų)

Fig. 2.5. SEM micrograph of silica fume at 150 000x magnitude

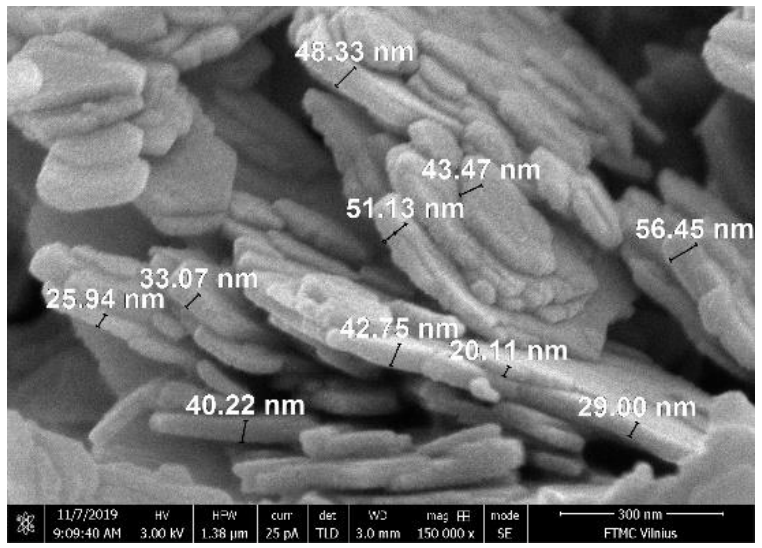

2.6 pav. Metakaolino SEM nuotrauka (didinimas 150000 kartų)

Fig. 2.6. SEM micrograph of metakaolin at 150 000x magnitude

Cementinès matricos plastifikavimui buvo naudojamas dideliu efektyvumu pasižymintis ir praktikoje plačiai naudojamas polikarboksilatų esterio pagrindu gaminamas superplastiklis, kurio sausų dalelių kiekis $30 \%$, rekomenduojamos dozavimo ribos normaliajam betonui $0,8-2 \%$ nuo cemento masés.

Cementinès matricos armavimui pasirinkti keli skirtingi plaušai (fibros) stiklo, bazalto, anglies bei polivinilo alkoholio (PVA), kurių pagrindinès charakteristikos pateiktos 2.3 lenteleje. PVA plaušas buvo pasirinktas dèl didelio deformacijų modulio (40 GPa), lyginant su dažnai naudojamais polipropileno ar poliolefino plaušais $(<10 \mathrm{GPa})$. Didžiausia dalis tyrimų atlikta su šarmams atspariu 
stiklo plaušu, kiti buvo naudojami kaip alternatyva siekiant gauti panašias arba geresnes mišinių bei sukietejusio betono savybes.

2.3 lentelè. Plaušų pagrindinès savybès

Table 2.3. Main physical characteristics of filaments

\begin{tabular}{|l|c|c|c|c|}
\hline \multirow{2}{*}{ Pagrindinès charakteristikos } & \multicolumn{4}{|c|}{ Skirtingų plaušu savybės } \\
\cline { 2 - 5 } & Stiklo & Bazalto & Anglies & PVA \\
\hline Tempimo stipris, MPa & 1400 & 3200 & 3000 & 800 \\
\hline Deformacijų modulis, $\mathrm{GPa}$ & 74 & 90 & 350 & 40 \\
\hline Terminis atsparumas, ${ }^{\circ} \mathrm{C}$ & $-50 \ldots+350$ & $-260 \ldots+700$ & 300 & 100 \\
\hline Lydymosi temperatūra, ${ }^{\circ} \mathrm{C}$ & 1100 & 1200 & 1200 & 225 \\
\hline Savitasis tankis, $\mathrm{kg} / \mathrm{m}^{3}$ & 2500 & 2700 & 1570 & 1300 \\
\hline Fibros ilgis, mm & 12 & 12 & 12 & 12 \\
\hline Plaušų kiekis fibroje, vnt. & 200 & 1500 & 3000 & 1 \\
\hline Vieno plaušo skersmuo, $\mu \mathrm{m}$ & 18 & 17 & 5 & 660 \\
\hline
\end{tabular}

\subsection{Mišinių sudėtys}

Atlikus mokslinès literatūros apžvalgą ir ịvertinus pirminių eksperimentinių tyrimų rezultatus, sukurta bazinè SPAB betono matricos sudètis, kuri buvo modifikuojama panaudojant skirtingus užpildus, plaušus bei priedus. Bazinei sudéčiai panaudotas rišiklio ir užpildo santykis 1:1, superplastiklio kiekis $1,1 \%$ nuo rišiklio masès, maksimalus plaušo kiekis $-2,9 \%$ nuo kietų medžiagų masès, vandens ir rišiklio santykis $-\mathrm{V} / \mathrm{C}=0,36$.

Tyrimuose naudotų betono mišinių sudéčių ruošimo principinè schema yra pateikta 2.7 paveiksle, o maišymo procesas aprašytas 2.3 .1 skyrelyje. Visos sudètys pateiktos E priede.

Tiriant skirtingų plaušų poveikị SPAB bazinès matricos savybėms, pasirinktas kontrolinis stiklo plaušo kiekis - 2,9\% nuo kietų medžiagų masès. Bazalto ir anglies plaušų kiekis sumažintas dèl jų didelio poveikio mišinio konsistencijai. PVA plaušo kiekis perskaičiuotas pagal savitaji tankị ir atitinka stiklo plaušo kiekị tūrio vienetais, kai pagal masę $-1,5 \%$ nuo kietų medžiagų masès. 


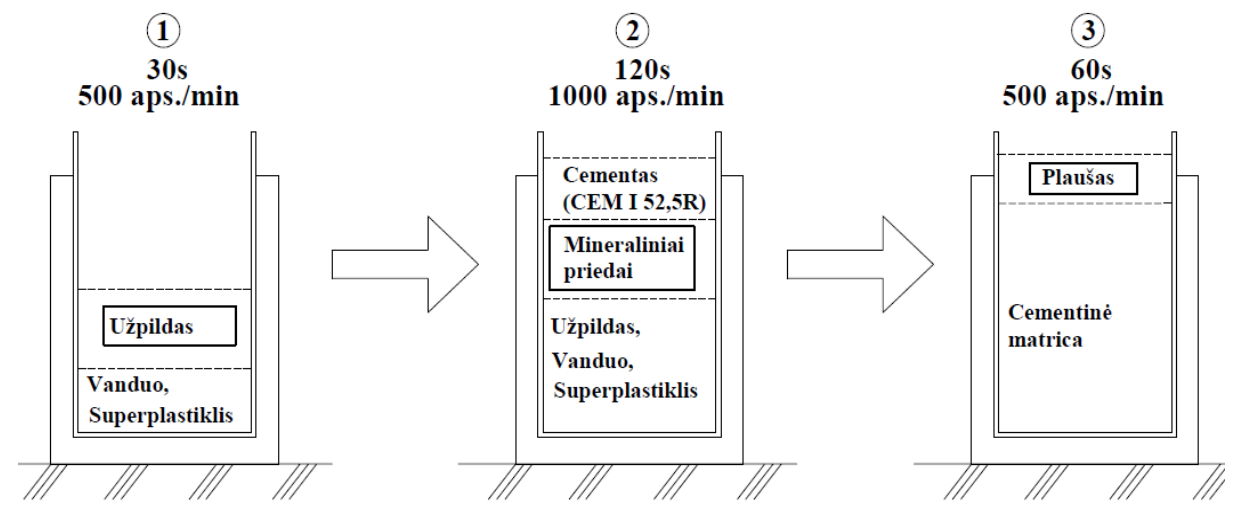

2.7 pav. Smulkiagrūdžio betono mišinių ruošimo schema ir betono sudečių komponentai Fig. 2.7. Concrete mix preparation scheme and used components

Siekiant ịvertinti skirtingų užpildų poveikị bazinès sudèties SPAB matricos konsistencijai bei mechaninėms savybèms, dalis kvarco buvo keičiama alternatyviais užpildais - granito atsijomis bei natūraliu smèliu, keičiant jų kiekị iki $50 \%$, intervalais kas $10 \%(0 \%, 10 \%, 20 \%, 30 \%, 40 \%, 50 \%)$. Visoms šioms sudètims buvo naudojamas stiklo plaušas.

Trečioji betono mišinių grupe skirta ịvertinti mineralinių priedų poveikị $\mathrm{SPAB}$ betono šalčio atsparumui. Mineralinių priedų (metakaolino ir $\mathrm{SiO}_{2}$ mikrodulkių) kiekiai buvo $0 \%, 2,5 \%, 5 \%$ bei 7,5 \% nuo rišiklio masès.

\subsection{Tyrimo metodai}

\subsubsection{Mišinių ruošimas ir bandinių formavimas}

Šiame tiriamajame darbe pasirinkta naudoti intensyvų maišytuvą (2.8 pav.), nes naudojant standartinę betono maišyklę, tolygiai permaišyti smulkių dalelių bei mažo vandens ir cemento santykio betono mišini yra labai sudètinga.

Atlikus seriją bandomujjų maišymų ir remiantis literatūroje pateiktomis rekomendacijomis, pasirinktas optimalus mišinių ruošimo režimas. Pirma supilamas vanduo, superplastiklis bei užpildas ir mišinys lètai permaišomas 20-30 s, kad užpildo dalelès pilnai sudrèktų. Po to dozuojamas rišiklis bei priedai ir mišinys maišomas 2 min maksimaliu maišytuvo greičiu - 1000 aps./min, kol pasiekia pastovią konsistenciją. Galiausiai supilamas plaušas ir maišoma 1 min pusę maišytuvo maksimalaus greičio - 500 aps./min. Pažymėtina, kad toks režimas 
tinkamas mišiniams su stiklo plaušu, kuomet stiklo plaušo fibros tolygiai pasiskirsto mišinio tūryje ir nesuyra i pavienius plaušelius, šitaip gaunant optimalios konsistencijos SPAB mišinị, kurio pasklidimas siekia $20 \mathrm{~cm}$ pagal 2.3.2 skyrelyje aprašytą metodiką.

Maišymo antgalis

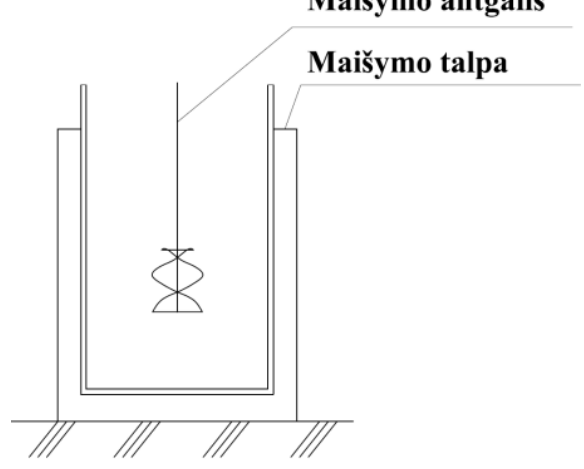

2.8 pav. Tyrimuose naudotas 1000 aps./min intensyvaus maišymo skiedinių maišytuvas

Fig. 2.8. $1000 \mathrm{rev} . / \mathrm{min}$ shear mixer for cementitious plasters

Bandinių gamybai buvo naudojami klojiniai iš laminuotos jūrinès faneros, kiekvienai betono sudèčiai formuojant plokštes, kurių matmenys: storis $-15 \mathrm{~mm}$, plotis - $525 \mathrm{~mm}$, aukštis - $525 \mathrm{~mm}$ (2.9a paveikslas). Plokštès išimamos iš klojinių po $24 \mathrm{~h}$ ir kietinamos 28 paras laboratorijos sąlygomis, $20{ }^{\circ} \mathrm{C}$ temperatūroje, $80 \%$ santykinio drègnio aplinkoje.

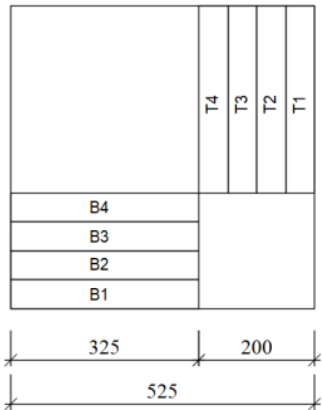

a)

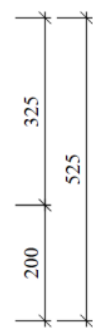

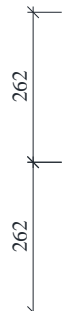

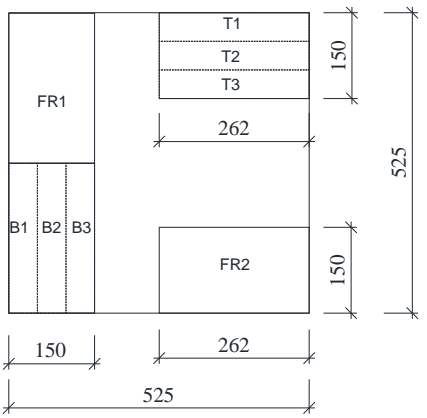

b)

2.9 pav. Bandyminių plokščiu formavimas: a) forma užpildyta betono mišiniu;

b) plokštelių pjaustymo schema lenkimo bandymams

Fig. 2.9. Casting of test plates: a) casted mould with concrete;

b) cutting scheme for flexural test plates 
Atliekant lenkimo stiprio bandymus, $15 \times 525 \times 525$ plokštès supjaustomos betono pjovimo disku i 8 plokšteles, kurių plotis $50 \mathrm{~mm}$, ilgis $325 \mathrm{~mm}$. Siekiant geriau ịvertinti plaušo pasiskirstymą gaminyje, plokštelès po 4 vnt. orientuojamos statmena kryptimi.

Atliekant atsparumo šalčiui bandymus, panaudotos tos pačios formos, iš kuriu pjaunamos keturios plokštelès, kurių matmenys $262 \times 150 \mathrm{~mm}(2.9 \mathrm{~b}$ pav.). Dvi iš jų supjaustomos ị $262 \times 50 \mathrm{~mm}$ bandinius, kurie naudojami nustatyti lenkimo stipriui po 28 parų, o kitos dvi plokštelès paruošiamos užšaldymo ir atšildymo bandymams pagal 2.13 paveiksle pateiktą schemą.

Gniuždymo stiprio nustatymui buvo naudojamos metalinès cementinių skiedinių formelès $40 \times 40 \times 160 \mathrm{~mm}^{3}$. Mišinys į formeles supilamas jo netankinant. Formose bandiniai laikomi 24 val. $20 \pm 2{ }^{\circ} \mathrm{Ctemperatūros} \mathrm{aplinkoje,} \mathrm{po} \mathrm{to} \mathrm{išfor-}$ muojami ir 27 paras laikomi $20 \pm 2{ }^{\circ} \mathrm{C}, 80 \%$ santykinio drègnio aplinkoje. Vienai betono suděčiai suformuojamos trys prizmès $40 \times 40 \times 160 \mathrm{~mm}^{3}$, kurios dalinamos i dvi dalis ir gaunami viso 6 bandiniai, kurie gniuždomi naudojant $40 \times$ $40 \mathrm{~mm}^{2}$ metalines plokšteles.

\subsubsection{Mišinių konsistencijos nustatymas}

Betono mišinių konsistencijos tyrimams pasirinktas cilindro pasklidimo metodas, tinkantis smulkiagrūdžiams cementiniams kompozitams su plaušais iki $20 \mathrm{~mm}$ ilgio. Bandymo metu naudojamas $\varnothing 65, \mathrm{~h}=55 \mathrm{~mm}$ metalinis cilindras, kuris padedamas ant glotnaus paviršiaus (stiklo arba jūrinès klojinių faneros) ir i ji supilamas betono mišinys. Po 15-20 s cilindras nukeliamas, leidžiama mišiniui pasklisti ir po $10-15 \mathrm{~s}$ išmatuojamas pasklidusio mišinio skersmuo, $\mathrm{cm}$ pagal 2.10 paveikslą.

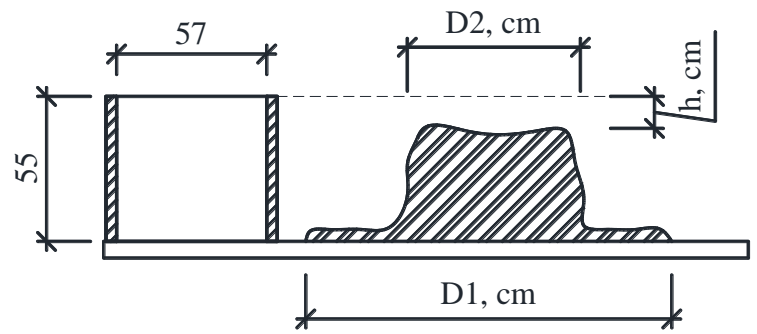

2.10 pav. Papildomi SPAB mišinių konsistencijos vertinimo parametrai

Fig. 2.10. Additional parameters for evaluation of GRC mix workability 
Remiantis 2.10 paveiksle pateikta schema, galime sukurti mišinio konsistenciją apibrèžiantị parametrą - segregacijos rodiklị $W$, kuris tiesiogiai proporcingas $D_{1}$ ir $D_{2}$, tačiau atvirkščiai proporcingas $h$ ir išreiškiamas pagal formulę:

$$
W=\frac{D_{1}-D_{2}}{h},
$$

čia, $D_{1}$ - cementinès tešlos pasklidimas, skaičiuojamas kaip vidurkis dviejų statmena kryptimi atliktų matavimų, $\mathrm{cm}$; $D_{2}$ - cementinès matricos su plaušu pasklidimas, skaičiuojamas kaip vidurkis dviejų statmena kryptimi atliktų matavimų, $\mathrm{cm} ; h$ - mišinio suslūgimas (Sutardo viskozimetro aukštis), $\mathrm{cm}$.

Kad geriau suprasti užpildo dalelių formos įtaką SPAB betono mišinio konsistencijai, apskaičiuotas dalelių vidutinès formos parametras - pailgumo indeksas $I$ :

$$
I=\frac{d_{1}}{d_{2}}
$$

čia, $d_{1}$ - užpildo dalelès ilgesnioji kraštinè, mm; $d_{2}$ - užpildo dalelès trumpesnioji kraštine, $\mathrm{mm}$;

\subsubsection{Betono mechaninių savybių nustatymas}

SPAB kompozitų mechaninès savybės dažniausiai charakterizuojamos lenkimo stipriu bei įtempių - deformacijų kreivèmis. Visi bandiniai buvo išbandyti pagal 4 atramų lenkimo schemą, kuri pateikta 2.11 paveiksle. Ši bandymo schema pranašesnè už 3 atramų dèl žymiai didesnio ploto, kuriame veikia maksimalūs tempimo įtempiai (atstumas L/3), kuomet 3 atramų schemoje maksimalūs įtempiai susidaro tik viename taške - jègos pridejjimo vietoje (LST EN 1170-4).

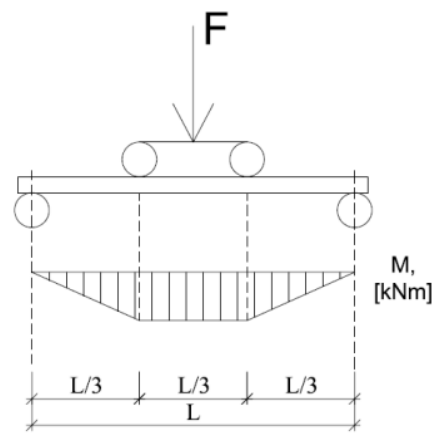

2.11 pav. Lenkimo bandymas pagal 4 atramų lenkimo schemą

Fig. 2.11. Testing according 4 - point bending scheme 
Kai atstumai tarp jègos pridejjimo taškų vienodi (L/3), lenkimo stipris apskaičiuojamas pagal formulę:

$$
\sigma=\frac{F L}{b h^{2}}
$$

čia, $\sigma$ - lenkimo stipris, MPa; $F$ - maksimali jèga, N; $L$ - atstumas tarp atramų centru, $\mathrm{mm} ; b$ - bandinio plotis, $\mathrm{mm} ; h$ - bandinio aukštis, $\mathrm{mm}$.

Siekiant bandinių deformacijų pobūdį apibrèžti skaitine išraiška, buvo panaudotas deformacijų energijos principas. Bendru atveju, deformacijas sukeliančios jègos atliktas darbas yra lygus jègos ir poslinkio sandaugai:

$$
A=F S \text {. }
$$

Prièmus prielaidą, kad visas išorinių jègų atliekamas darbas yra sunaudojamas plyšio didejjimui, galima teigti, kad deformacijų energija $G_{f}$ yra tiesiogiai proporcinga darbui ir skaičiuojama pagal 2.3 formulę, pasiūlytą RILEM asociacijos (Jaras A. C. ir Litherland, K. L. 1975). Šioje formuleje neįskaičiuotas savojo svorio jègų atliekamas darbas, nes bandinių savasis svoris sukelia labai nežymias deformacijas.

$$
G_{f}=\frac{A_{0}}{A_{\text {lig }}},
$$

čia, $G_{f}$ - lenkimo deformacijų energija, N/m; $A_{0}$ - bandymų mašinos atliekamas darbas, kuris yra lygus plotui po jègų - poslinkių kreive (2.12 pav. ir 2.6 formulè), $\mathrm{Nm} ; A_{\text {lig }}-$ plyšio plotas (bandinio skerspjūvio plotas), $\mathrm{mm}^{2}$;

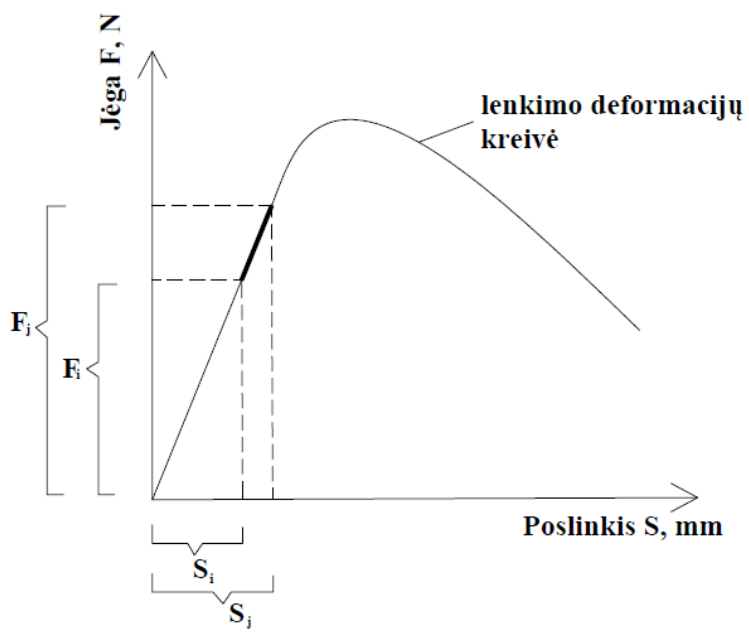

2.12 pav. Bandymų mašinos atliekamo darbo apskaičiavimas

Fig. 2.12. Calculation of work done by testing machine 


$$
A_{0}=\sum\left(\frac{F_{j-} F_{i}}{2}\right)\left(s_{j-} s_{i}\right)
$$

kur, $F_{j, i}-$ jègos koordinatès, $\mathrm{N} ; s_{j, i}-$ poslinkio koordinatès, $\mathrm{m}$.

\subsubsection{Atsparumo šalčiui nustatymas}

Betono atsparumas šalčiui buvo nustatomas paviršinio šaldymo metodu. Bandiniai buvo išlaikomi klimato kameroje iki 112 užšaldymo ir atšildymo ciklų, kai vieno ciklo trukmé - 24 valandos (2.13 pav.). Kiekvieno bandinio $150 \times$ $262 \mathrm{~mm}$ bandomasis betono paviršius $\left(39300 \mathrm{~mm}^{2}\right)$ buvo padengtas $5 \mathrm{~mm}$ storio $3 \%$ koncentracijos $\mathrm{NaCl}$ tirpalu. Kas 7 paras bandiniai, ne ilgiau kaip 30 min, išimami iš šaldymo kameros, nupilamas $\mathrm{NaCl}$ tirpalas, bandinio paviršius šveičiamas metaliniu šepečiu ir plaunant vandens srove surenkami atskilę paviršiaus fragmentai, kurie išdžiovinami, pasveriami ir apskaičiuojami paviršiaus masès nuostoliai $\mathrm{g} / \mathrm{m}^{2}$. Bandiniai, paruošti atsparumo šalčiui tyrimams atvaizduoti 2.14 paveiksle.

Iprastiniam betonui, pagal LST EN 13198 reikalaujama mažiausiai 28 užšaldymo ir atšildymo ciklų ir $7500 \mathrm{~mm}^{2}$ minimalaus bandinio ploto, kai naudojamas druskos tirpalas, o 56 paviršinio užšaldymo ir atšildymo ciklai atitinka maksimalią atsparumo šalčiui klasę XF4. Taigi, šiame tiriamajame darbe atlikti bandymai 2 kartus viršija maksimalius norminius reikalavimus ịprastiniam betonui.

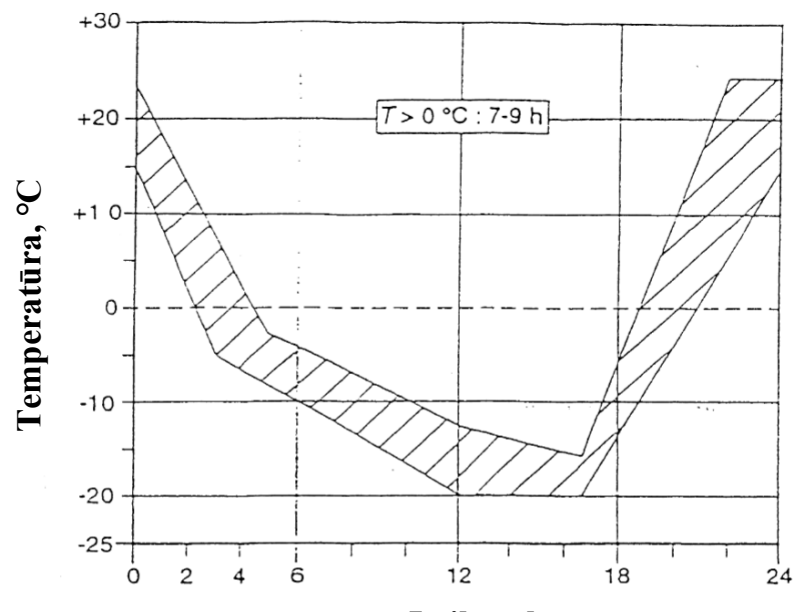

Laikas, $\mathbf{h}$

2.13 pav. Laiko - tempetarūros ciklas pagal LST EN 13198

Fig. 2.13. Time - temperature cycle according LST EN 13198 

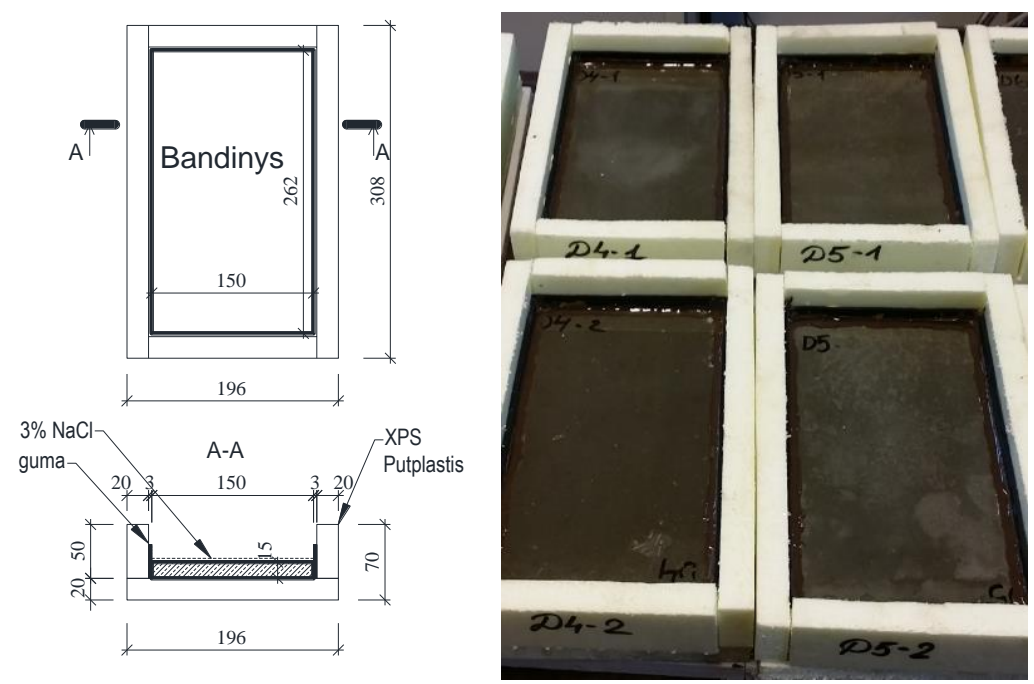

2.14 pav. Bandinių paruošimo schema

Fig. 2.14. Specimens for freeze/thaw tests

Atliekant atsparumo šalčiui tyrimus, taip pat buvo nustatomas lenkimo stipris, sudaromos lenkimo deformacijų kreivès, pagal kurias skaičiuojamos deformacijų energijos prieš ir po užšaldymo ir atšildymo ciklų poveikio. Tuo tikslu $150 \times$ $262 \mathrm{~mm}^{2}$ bandiniai buvo supjaustomi i plokšteles $48 \times 262 \mathrm{~mm}^{2}$, kurios naudojamos lenkimo stiprio bandymuose.

\subsubsection{Technologinių ir kitų savybių nustatymas}

Itraukto oro kiekis betono mišinyje nustatytas naudojant slėginị metodą, vadovaujantis LST EN 12350-7 standarto reikalavimais. Sukietejusio betono tankis nustatytas naudojant prizmes $40 \times 40 \times 160 \mathrm{~mm}$, o betono mišinio tankis -11 tūrio indą.

Bandinių mikrostruktūra buvo tiriama naudojant SEM JEOL JSM-7600F skenuojantị elektroninị mikroskopą. Tyrimo metu naudota $30 \mathrm{kV}$ ịtampa. Prieš atliekant tyrimą, skėlimo paviršius buvo padengtas plonu aukso sluoksniu, vakuume garinant aukso elektrodą „QUORUM Q15OR ES“ prietaisu. Vaizdas buvo didinamas nuo 5000 iki 150000 kartų.

Dalelių formai nustatyti, visi trys užpildai buvo suskaidyti į frakcijas sijojant per standartinius sietus: $2-4 \mathrm{~mm}, 1-2 \mathrm{~mm}, 0,5-1 \mathrm{~mm}, 0,25-0,5 \mathrm{~mm}, 0,125-0,25$ $\mathrm{mm}, 0,063-0,125 \mathrm{~mm}$, padarytos kiekvienos frakcijos mikroskopinès nuotraukos. Nuotraukas įkèlus ị programą Autocad, matavimo įrankių pagalba buvo nustatomi 
pailgumo indeksai (I) pasirenkant po 30 dalelių iš kiekvienos frakcijos ir išvedamas vidurkis. Kadangi pailgumo indeksas $I$ skaičiuojamas kaip dalelių matmenų statmena kryptimi santykis, nuotraukų mastelis Autocad modelio erdveje tam įtakos neturi.

\subsection{Antrojo skyriaus išvados}

1. Siekiant sukurti dispersiškai armuotą apdailinị betoną, kuris būtų atsparus agresyviam užšaldymo ir atšildymo ciklų poveikiui, buvo parinktos betono mišinių sudètys su skirtingais užpildais (kvarcinis smèlis, granito atsijos, ịprastinis žvyro karjerų smèlis), plaušais (stiklo, bazalto, anglies bei polivinilo alkoholio) ir cementinès matricos struktūrą modifikuojančiais priedais $\left(\mathrm{SiO}_{2}\right.$ mikrodulkès ir metakaolinas).

2. Smulkiagrūdžiams betono mišiniams būdingas didelis smulkiụjų dalelių (cemento ir užpildo) kiekis, kurias maišymo metu sudètinga homogenizuoti, todèl pasirinktas intensyvaus maišymo metodas, kuris užtikrina visų mišinio komponentų homogeniškumą.

3. Dispersiškai armuoto apdailinio betono mišinio svarbiausios technologinès savybès - konsistencija ir segregacija, kurias galima vertinti pagal mišinio pasklidimo ir suslūgimo parametrus.

4. Lenkiamų plonasienių dispersiškai armuotų betono elementų mechaninių savybių pokyčius tikslinga vertinti pagal lenkimo deformacijų energiją, kuri tiesiogiai proporcinga bandymų mašinos atliekamam darbui. 


\section{Mineraliniais priedais modifikuoto apdailinio betono su dispersiniu armavimu technologinių ir eksploatacinių savybių tyrimai}

Šio tyrimo tikslas yra sukurti dispersiškai armuotą smulkiagrūdị apdailinị betoną (DASAB), skirtą naudoti fasadų surenkamujų sieninių elementų pramoninejje gamyboje. Tyrimo metu panaudoti skirtingi plaušai (stiklo, bazalto, anglies, PVA), užpildai (kvarcinis smëlis, granito atsijos, iprastinis Lietuvos karjerų smèlis) bei betono savybes modifikuojantys mineraliniai priedai (metakaolinas ir $\mathrm{SiO}_{2}$ mikrodulkès). Nustatytas skirtingų komponentų poveikis betono konsistencijai, mechaninèms savybèms ir atsparumui šalčiui.

Skyriaus tematika paskelbti septyni autoriaus straipsniai (Moceikis et al., 2017, 2018a, 2018b, 2018c, 2019a, 2019b, 2020). 


\subsection{Smulkiagrūdžio apdailinio betono su skirtingais plaušais technologinių bei mechaninių savybių tyrimai}

\subsubsection{Betono mišinio konsistencija}

Plonasieniams gaminiams iš DASAB svarbu, kad matricos struktūrą armuojantis plaušas būtų orientuotas kiek įmanoma labiau horizontalioje padètyje, sutampančioje su išorinių tempimo jëgų veikimo kryptimi. Taip pat, liejamo formavimo būdu gaminamų gaminių betono mišinys turi būti technologiškas ir takaus, tai yra laisvai pasklisti ir užpildyti klojinius (formas).

Mokslininkai rekomenduoja tokio tipo mišiniams plaušo dozuoti neviršijant 3,0 \% nuo sausų medžiagų masès (Abe et al., 2011). Šiuose tyrimuose geros konsistencijos mišiniai pagaminti naudojant $2,9 \%$ stiklo plaušo.

Atliekant bandymus su skirtingais plaušais, pastebèta, kad panaudojus bazalto bei anglies plaušus mišinio konsistencija itin pablogejja ir priklauso nuo maišymo režimo parametrų, o mišiniams su stiklo ir polivinilo alkoholio (PVA) plaušais maišymo parametrai turi nedidelę įtaką. Konsistencijos pokyčiai susiję su tuo, kad maišymo metu fibros suyra i pavienius plaušelius, kurie plačiai pasiskirsto matricos tūryje ir padideja plaušo - matricos kontaktinès zonos plotas, kas taip pat buvo nustatyta kitų mokslininkų tyrimuose (Branston et al., 2016; Yakhlaf et al., 2013; Safiudin et al., 2018). Ivertinus mokslininku atliktus tyrimus, buvo pasirinkta atlikti bandymus su 2,9 \%, 1,45 \% bazalto plaušo kiekiais ir 0,72 \%, $0,18 \%$ anglies plaušo kiekiais. Pasirinktas PVA plaušo kiekis $(1,5 \%)$ atitinka plaušo kiekị pagal tūrị, nes šių medžiagų tankiai skiriasi beveik du kartus.

Mišinių su skirtingais plaušais pasklidimai pateikti 3.1 ir 3.2 paveiksluose. Kaip matome, panaudojus stiklo ir PVA plaušus, pasklidimas sumažèjo vos $1 \mathrm{~cm}$ (5\%) lyginant su tos pačios sudèties cementine matrica (skiediniu) be plaušo. Pasklidimo metu mišiniai išlieka stabilios struktūros, stiklo ir PVA plaušai tolygiai pasiskirsto visame tūryje, beveik nedarydami ịtakos mišinio konsistencijai.

Panaudojus tokị pat kiekị bazalto plaušo kaip ir mišiniuose su stiklo plaušu, gaunamas standus mišinys. Sumažinus bazalto kieki 50 \% mišinio konsistencija pagerejja, gaunamas nedidelis $-12 \mathrm{~cm}$ pasklidimas.

Anglies plaušo panaudojimas tokio tipo betono mišiniuose yra problematiškas. Dozuojant vos $0,7 \%$ plaušo nuo cemento masès, gaunamas standus ir netechnologiškas mišinys, kuriam reikalingas intensyvus tankinimas ir kuris nèra tinkamas daugumai betono gaminių formavimo technologinių procesų Net itin sumažinus anglies plaušo kiekį - iki $0,18 \%$, gaunamas analogiškos konsistencijos, standus betono mišinys. 


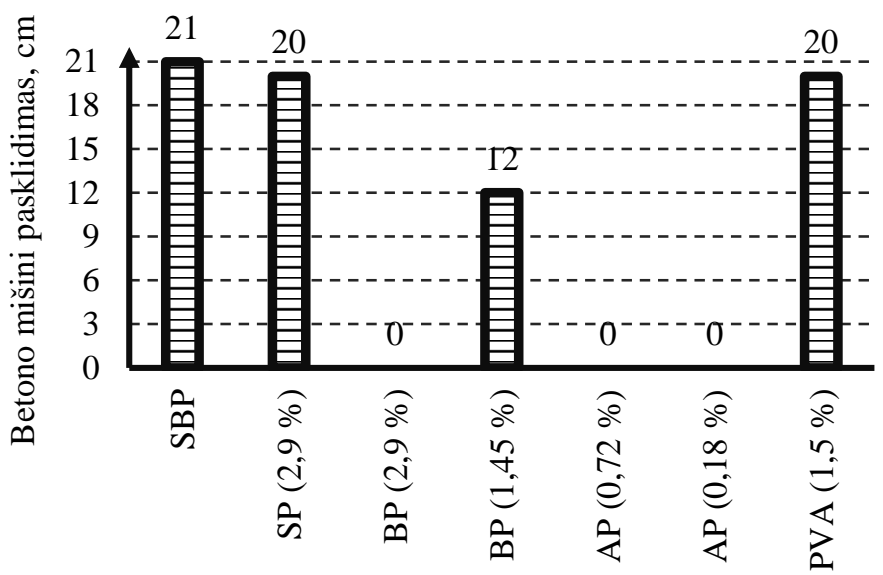

3.1 pav. Smulkiagrūdžio betono mišinių pasklidimo bandymai su skirtingais plaušais ir jų kiekiais

Fig. 3.1. Fine-grained Concrete mix spread test result with different fibres and their quantities

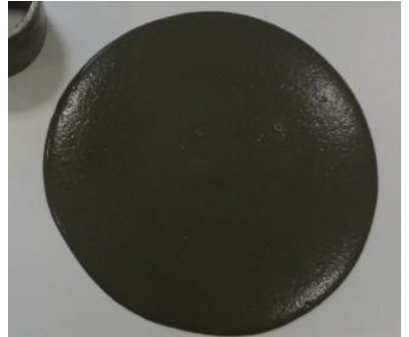

a)

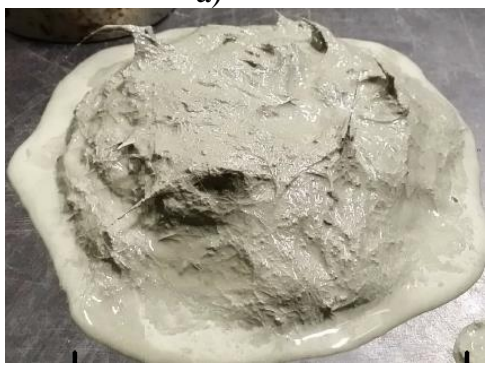

c)

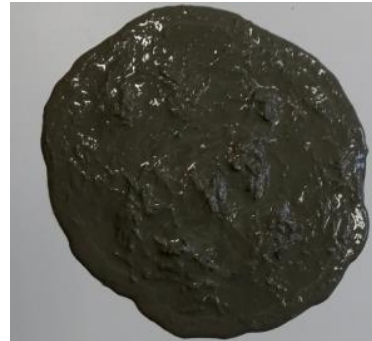

b)

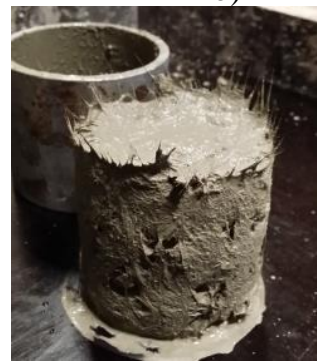

d)

3.2 pav. Smulkiagrūdžio betono mišinių konsistencija su skirtingais plaušais:

a) mišinys be plaušų (REF0); b) 2,9 \% stiklo plaušo (S1); c) 1,45 \% bazalto plaušo (B1); d) $0,7 \%$ anglies plaušo

Fig. 3.2. Workability of fine-grained concrete mix with different fibers: a) without fiber (REF0); b) 2,9\% glass fiber (S1); c) 1,45\% basalt (B1); d) 0,7\% carbon fiber 
Ruošiant betono mišinius, anglies ir bazalto plaušų aglomeratai suyra ị pavienius plaušelius, kadangi tarp jų veikia labai silpnos tarpusavio traukos jègos. Taip gaunamas standus bei netechnologiškas betono mišinys. Todèl šiuo požiūriu yra tinkamesnis stiklo plaušas, kurio plaušeliai net prie intensyvaus maišymo lieka sukibę ị aglomeratus ir išlieka tiesios formos, taip užtikrindami reikiamą mišinio pasklidimą ir pakankamą cementinès matricos armavimą.

Standūs smulkiagrūdžiai mišiniai su bazalto bei anglies plaušu gali būti panaudoti gelžbetonio konstrukcijų jungiamujjų siūlių betonavimui. Šiuo tikslu dažnai naudojama kilpinè sienu jungtis yra veikiama kirpimo jègų, o anglies ir bazalto plaušai itin padidina betono stiprị kerpant/skeliant (Safiudin et al., 2018; Fiore et al., 2015; Khandel et al., 2020). Taip pat, naudojant injektuojamus standžius mišinius, padidètų montavimo darbų našumas, nes siūlių užpildymui nereikalingi klojiniai.

\subsubsection{DASAB betono mechaninès savybès ir plaušo parinkimas}

Betono armavimui dažniausiai naudojamas armatūrinis plienas, kuris pasižymi geromis tempimo charakteristikomis ir itin padidina betono standumą bei stiprumą. Iprastinio armatūrinio plieno takumo riba tempiant $500 \mathrm{MPa}$, o pasipriešinimas deformacijai (deformacijų modulis) - $200 \mathrm{GPa}$. Tačiau armatūrinis plienas yra labai lengvai paveikiamas atmosferinès korozijos, jam reikalingi dideli betono apsauginiai sluoksniai. Tačiau plieninė armatūra pasižymi dideliu atsparumu ugniai (kritinè plieno temperatūra konstrukcijoje $500^{\circ} \mathrm{C}$ ) ir gebejjimu plastiškai deformuotis. Šios dvi charakteristikos yra esminès projektuojant saugius statinius ir naudojant alternatyvias medžiagas plienui ị jas būtina atsižvelgti. Vietoje armatūrinio plieno taip pat galima panaudoti ir ịvairius plaušus, kurie savo mechaninèmis ir fizikinèmis savybėmis nenusileidžia o kai kuriais atvejai net lenkia plieną.

Šarmams atsparus stiklo plaušas pasižymi dideliu tempimo stipriu $1400 \mathrm{MPa}$, aukštu deformacijų moduliu - $74 \mathrm{GPa}$ ir geru terminiu atsparumu $(-50 \ldots+350)$. Bazaltui būdingas ypatingai didelis tempimo stipris - iki $3200 \mathrm{MPa}$, deformacijų modulis artimas stiklui - $90 \mathrm{GPa}$, o terminis atsparumas - vienas didžiausių tarp žinomų medžiagų $(-260 \ldots+700)$. Anglies plaušas sparčiai populiareja ịvairiose pramonès šakose dèl ypatingai didelio tempimo stiprio $3000 \mathrm{MPa}$ ir standumo, kuris net viršija plieno - $350 \mathrm{GPa}$, o terminis atsparumas artimas stiklui. Polivinilo alkoholio (PVA) plaušas priskiriamas polimeru grupei, todèl nepasiekia didelio terminio atsparumo (iki $100^{\circ} \mathrm{C}$ ), tačiau turi geras mechanines savybes (tempimo stipris - $800 \mathrm{MPa}$, deformacijų modulis - $40 \mathrm{GPa}$ ). Tai geriausi parametrai iš polimerų grupés plaušų, kuomet labiausiai paplitusio polipropileno deformacijų modulis nesiekia net $10 \mathrm{GPa}$. 
Atliekant DASAB mechaninių savybių bandymus nustatyta, kad plaušai lenkimo stipri padidino iki $62 \%$. Mažiausias lenkimo stipris užfiksuotas bandiniuose be plaušų - 6,5 MPa, kai įlinkis $0,25 \mathrm{~mm}$. Didžiausią lenkimo stiprị pasiekè bandiniai su 2,9 \% stiklo plaušo - 13,3 MPa (3.3 pav.). Didžiausias gniuždymo stipris - 92,7 MPa gautas panaudojus $0,72 \%$ anglies plaušo, mažiausias - 64,3 MPa su $1,5 \%$ PVA plaušo (3.4 pav.). Stiklo plaušas beveik nedare ịtakos cementinės matricos gniuždymo stipriui, ką taip pat patvirtina ir kitų mokslininkų atlikti tyrimai (Madhkhan et al., 2019).

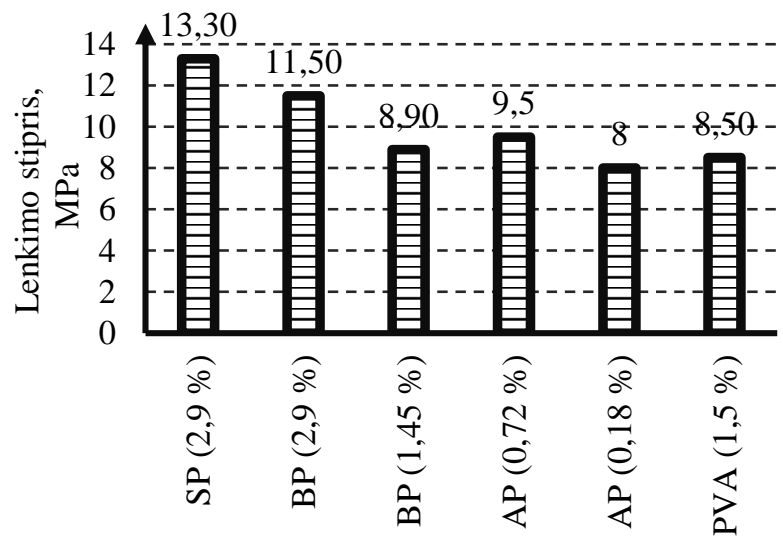

3.3 pav. Smulkiagrūdžio betono su skirtingais plaušais ir jų kiekiais lenkimo stipris

Fig. 3.3. Fine-grained concrete flexural strength test result with different fibres and their quantities

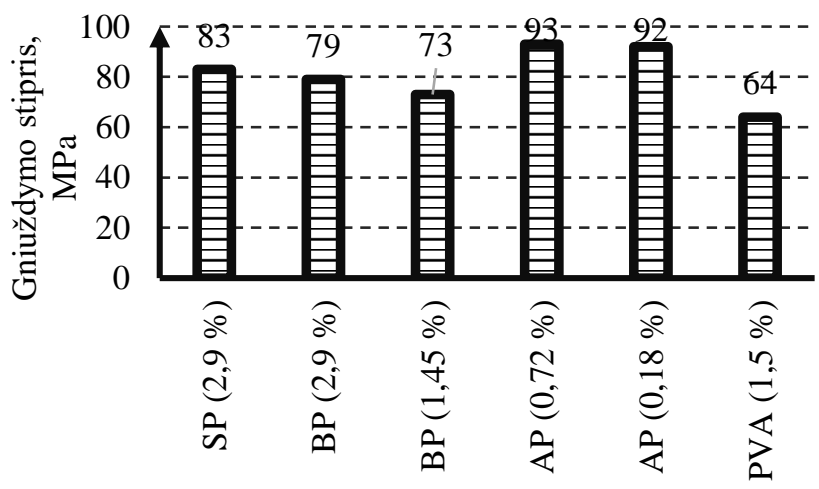

3.4 pav. Smulkiagrūdžio betono su skirtingais plaušais ir jų kiekiais gniuždymo stipris

Fig. 3.4. Fine-grained concrete compressive strength test result with different fibres and their quantities 
Remiantis medžiagų mechanikos teorija galima teigti, kad suardymo energija yra naudingas bei išsamus DASAB mechaninio atsparumo rodiklis, kadangi šiai medžiagai būdingas plastinio pobūdžio suirimas (Mills et al., 1981). DASAB irimo procesą geriausiai charakterizuoja lenkimo deformacijų energija, nes ji išreiškiama darbu, reikalingu pilnai suardyti bandinị. Patterson (1975) tyrinejjo suirimo energijos metodikas, kad ịvertinti SPAB betono atsparumą suardymui, o darbas, sunaudotas statinio plyšio pločio didejimo metu, buvo naudojamas kaip pagrindinè charakteristika medžiagos stiprumui nustatyti.

Atlikus lenkimo bandymus, pagal kiekvieno bandinio deformacijų kreivių skaitinius duomenis, Excel programos pagalba buvo suskaičiuoti plotai po kreivèmis bei lenkimo deformacijų energijos vidurkiai, būdingi tai sudęčiai. Atlikus skaičiavimus, mažiausia gauta deformacijų energija $-27 \mathrm{~N} / \mathrm{m}$, bandiniams be plaušų, o didžiausia - $3102 \mathrm{~N} / \mathrm{m}$, bandiniams su PVA plaušu (3.5 pav.).

3.6 paveiksle pateikti lenkimo deformacijų kreivių vidurkiai, būdingi kompozitams su skirtingais plaušais. Kuo didesnis plotas po kreive, tuo daugiau energijos reikia suardyti šiai medžiagai.

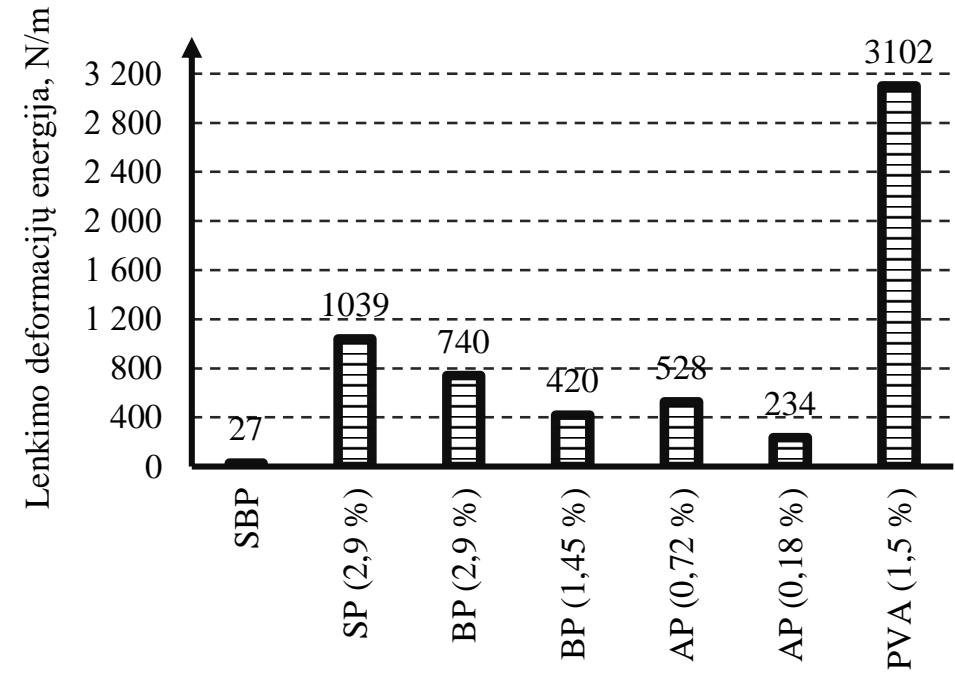

3.5 pav. Smulkiagrūdžio betono su skirtingais plaušais lenkimo deformacijų energija

Fig. 3.5. Flexural strain energies of fine-grained concrete with different fibers 


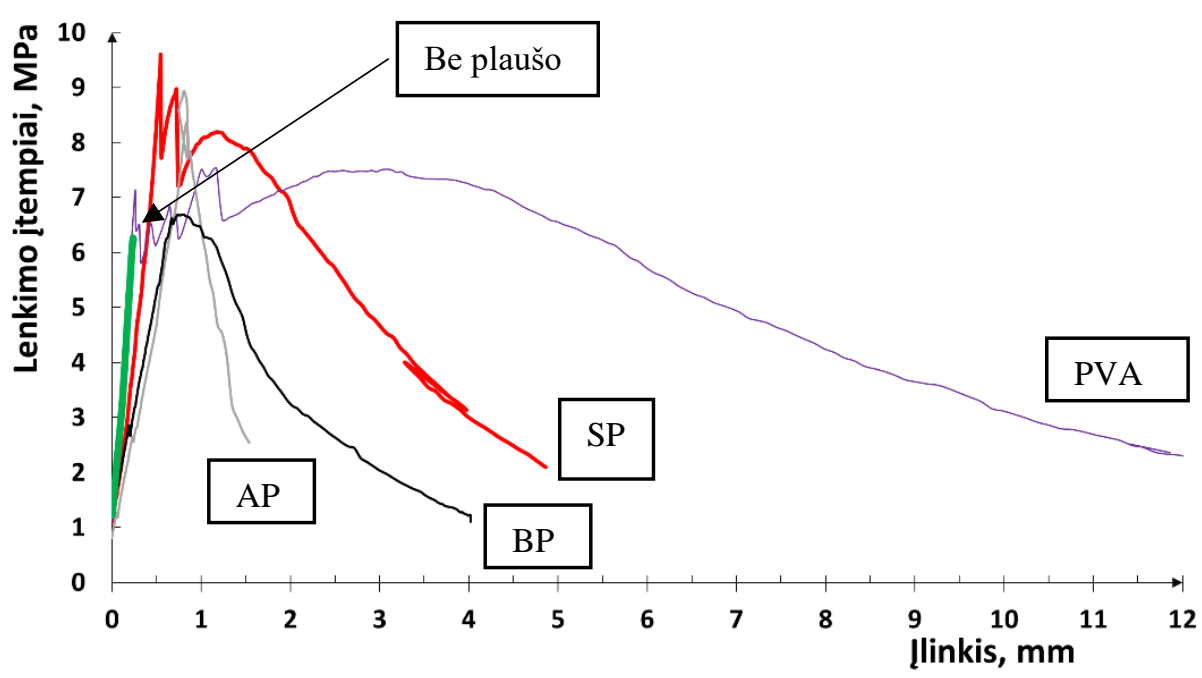

3.6 pav. Smulkiagrūdžio betono skirtingais plaušais lenkimo deformacijų kreivès

Fig. 3.6. Stress-deflection curves of fine-grained concrete with different fiber

Apibendrinant DASAB betono su skirtingais plaušais mechanines savybes, galima teigti, kad stiklo plaušas cementinès matricos lenkimo deformacijų energiją padidino 38 kartus, o polivinilo alkoholio plaušas 114 kartų, taip suteikdami trapiai medžiagai plastiškumo savybių, kai plaušų dozuojama atitinkamai 2,9\% ir 1,5\% nuo cementinès matricos sausų medžiagų masès. Nors didžiausias gniuždymo stipris gautas su anglies plaušu, tačiau lenkimo deformacijas sukeliančių jègų veikiamiems elementams ši charakteristika nèra tokia svarbi.

Fenu (2016) ištyrè, kad stiklo plaušas pagerina betono mechanines charakteristikas tiek veikiant statinėms, tiek dinaminėms apkrovoms. Veikiant statinėms apkrovoms, gautas didesnis lenkimo stipris bandiniuose su stiklo plaušu, negu naudojant bazalto plaušą. Taip pat stiklo plaušas suteikè kompozitui didesnị smūginị tąsumą nei bazaltas, veikiant dinaminèms apkrovoms.

Dispersiškai armuoto smulkiagrūdžio apdailinio betono plaušo parinkimui būtina atsižvelgti atsižvelgiant ị šiuos pagrindinius kriterijus: mišinio konsistenciją, segregaciją, betono lenkimo stiprị bei suirimo energiją. Tolimesniems atsparumo šalčiui tyrimams buvo pasirinkta naudoti šarmams atsparų stiklo plaušą, nes šis geriausiai atitinka šiuos kriterijus. Vertinant pagal betono mišinio konsistenciją ir mechanines charakteristikas (deformacijų energiją), geriausių rezultatų pasiekta naudojant PVA plaušą. Verta paminèti, kad šio polimero deformacijų modulis 10 kartų didesnis, nei polipropileno, kuris dažnai naudojamas betono mišnių gamyboje kaip plastinio traukumo deformacijas mažinantis priedas, bet nèra efektyvus betono armavimui. Tačiau kaip ir visiems polimerams, PVA plaušui 
būdingas mažas terminis atsparumas $\left(<100{ }^{\circ} \mathrm{C}\right)$, todèl jo panaudojimas fasadų konstrukcijoms yra pakankamai ribotas, kur yra keliami griežti priešgaisriniai reikalavimai.

\subsection{Stiklo plaušu armuotų betonų segregacijos ir konsistencijos tyrimai}

\subsubsection{Užpildų poveikis stiklo plaušu armuotų mišinių konsistencijai}

Labiausiai ištyrinètas ir dažniausiai naudojamas užpildas smulkiagrūdžių betonų sistemose yra kvarcinis smèlis. Šis pasirinkimas pagrịstas ypatingai gera mišinių konsistencija naudojant ši užpildą (Abe et al., 2011; Bartos et al., 2017). Kadangi šiame darbe tyrinèjami takūs betono mišiniai, ypatingai svarbus mišinio gebejjimas greitai ir tolygiai pasklisti bei užpildyti formuojamo gaminio klojinị. Gaminant plonasienius gaminius, sudètinga pritaikyti betono sutankinimo priemones. Todèl svarbus reikalavimas, keliamas DASAB mišiniams yra mišinio pasklidimas, suslūgimas ir atsparumas segregacijai. Mišinio segregacija šiuo atveju apibrèžiama, kaip plaušo ir cementinès matricos atsiskyrimas, pavaizduotas 3.7 paveiksle.

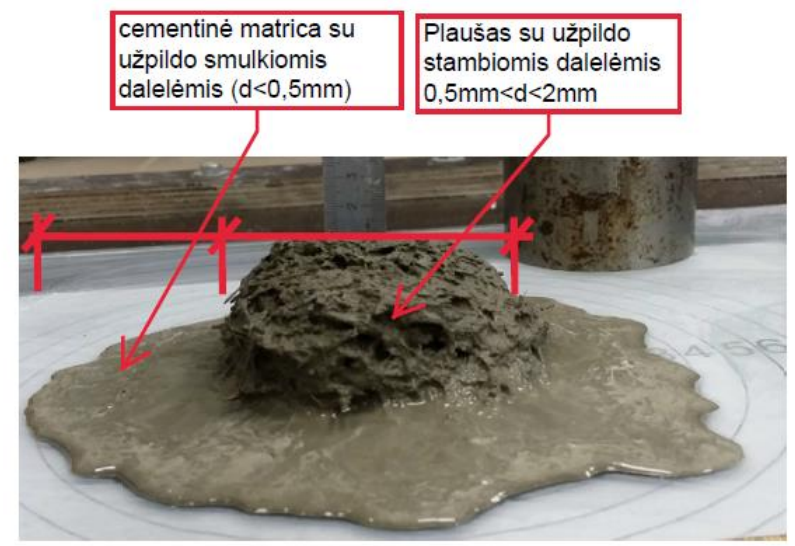

3.7 pav. Dispersiškai armuoto smulkiagrūdžio betono mišinio segregacija

Fig. 3.7. Segregation of dispersively reinforced finegrained concrete mix 
Naudojant kvarcinį smèli, gauti tinkamos konsistencijos takų ir savaime išsilyginantị SPAB mišinį nėra sudètinga. Siekiant nustatyti skirtingų užpildų kiekio poveiki betono konsistencijai, buvo gaminami mišiniai, kuriuose kvarco matrica buvo pakeista $10 \%, 20 \%, 30 \%, 40 \%, 50 \%$ alternatyviais užpildais - granito atsijomis bei ịprastiniu smèliu (sudettys pagal 2.8 ir 2.9 lenteles). Panaudojus alternatyvius užpildus, itin pablogejo mišinio konsistencija, kai kuriais atvejais gauta didelè plaušo - matricos segregacija. Norint išsamiai apibūdinti tokių mišinių konsistenciją, neužtenka vien ịprastinio suslūgimo $(h)$ nustatymo, pagal Sutardo viskozimetro aukšti. Papildomai reikia išmatuoti mišinio pasklidimo skersmenis $D_{1}$ ir $D_{2}$, kurie apibūdina segregacijos efektą.

Pagal kiekvienos frakcijos kiekị ant skirtingų sietų, buvo suskaičiuoti vidutinès formos pailgumo indeksai visam užpildui: $I_{\mathrm{kv}}=1,40$ (kvarciniam smèliui), $I_{\text {sum }}=1,44$ (iprastiniam smèliui), $I_{\mathrm{gr}}=1,87$ (granito atsijoms) ir pateikti 3.1 lentelès apačioje. Kaip rodo atliktų bandymų rezultatai, didèjant dalelių pailgumo indeksui, betono mišinio konsistencija blogèja.

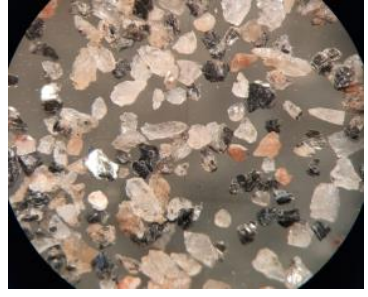

a)

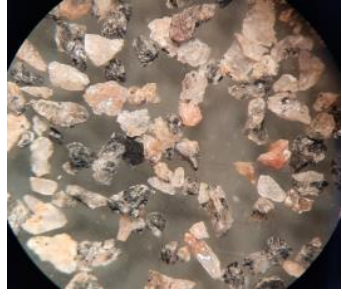

b)

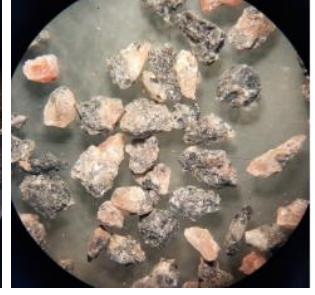

c)

3.8 pav. Granito užpildo formos tyrimai optiniu mikroskopu: a) $250 \mu \mathrm{m}$ sietas, 25x didinimas; a) $500 \mu \mathrm{m}$ sietas, $12 \mathrm{x}$ didinimas; c) $1 \mathrm{~mm}$ sietas, 25x didinimas

Fig. 3.8. Optical microscope investigation of granite particle shape: a) $250 \mu \mathrm{m}$ sieve, 25x magnitude; a) 500 $\mu \mathrm{m}$ sieve, 12x magnitude; c) $1 \mathrm{~mm}$ sieve, 25x magnitude

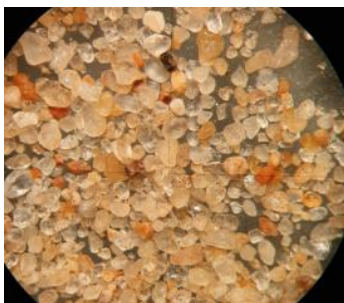

a)

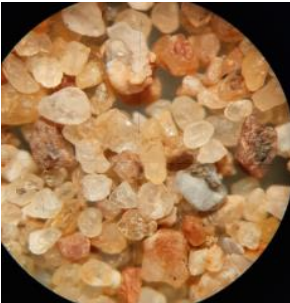

b)

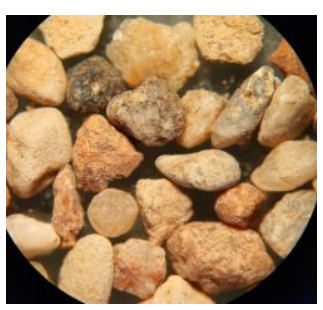

c)

3.9 pav. Iprastinio smèlio užpildo formos tyrimai optiniu mikroskopu: a) $250 \mu \mathrm{m}$ sietas, 25x didinimas; a) 500 $\mu \mathrm{m}$ sietas, $12 \mathrm{x}$ didinimas; c) $1 \mathrm{~mm}$ sietas, 25x didinimas Fig. 3.9. Optical microscope investigation of regular sand particle shape: a) $250 \mu \mathrm{m}$ sieve, 25x magnitude; a) $500 \mu \mathrm{m}$ sieve, $12 \mathrm{x}$ magnitude; c) $1 \mathrm{~mm}$ sieve, 25x magnitude 


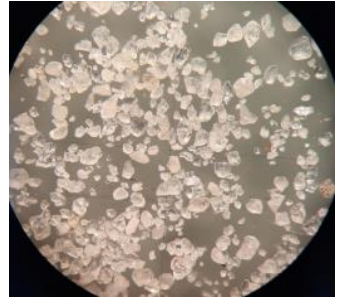

a)

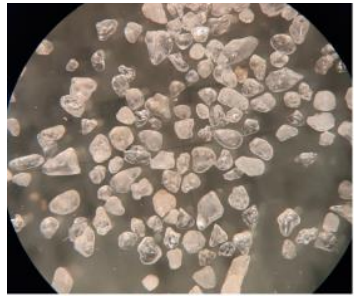

b)

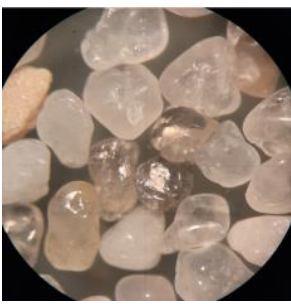

c)

3.10 pav. Kvarco užpildo formos tyrimai optiniu mikroskopu: a) $250 \mu \mathrm{m}$ sietas, 25x didinimas; a) $500 \mu \mathrm{m}$ sietas, 12x didinimas; c) $1 \mathrm{~mm}$ sietas, 25x didinimas

Fig. 3.10. Optical microscope investigation of quartz particle shape: a) $250 \mu \mathrm{m}$ sieve, 25x magnitude; a) $500 \mu \mathrm{m}$ sieve, $12 \mathrm{x}$ magnitude; c) $1 \mathrm{~mm}$ sieve, 25x magnitude

3.1 lentelè. Užpildų pailgumo indeksų skaičiavimo rezultatai

Table 3.1. Determination of particle shape index

\begin{tabular}{|c|c|c|c|c|c|c|}
\hline \multirow{2}{*}{ Frakcija } & \multicolumn{2}{|c|}{ Kvarcinis smėlis } & \multicolumn{2}{c|}{ Iprastinis smėlis } & \multicolumn{2}{c|}{ Granito atsijos } \\
\cline { 2 - 7 } & $\begin{array}{c}\text { Kiekis, } \\
\%\end{array}$ & $\begin{array}{c}\text { Pailgumo } \\
\text { indeksas } I\end{array}$ & $\begin{array}{c}\text { Kiekis, } \\
\%\end{array}$ & $\begin{array}{c}\text { Pailgumo } \\
\text { indeksas } I\end{array}$ & $\begin{array}{c}\text { Kiekis, } \\
\%\end{array}$ & $\begin{array}{c}\text { Pailgumo } \\
\text { indeksas } I\end{array}$ \\
\hline $2-4$ & 0,0 & $\mathbf{0}$ & 11,8 & $\mathbf{1 , 3 8}$ & 13,9 & $\mathbf{2 , 0 0}$ \\
\hline $1-2$ & 0,3 & $\mathbf{1 , 2 1}$ & 20,0 & $\mathbf{1 , 3 1}$ & 20,7 & $\mathbf{2 , 2 0}$ \\
\hline $0,5-1$ & 5,2 & $\mathbf{1 , 3 7}$ & 22,3 & $\mathbf{1 , 3 2}$ & 27,6 & $\mathbf{1 , 7 6}$ \\
\hline $0,25-0,5$ & 37,6 & $\mathbf{1 , 3 4}$ & 23,3 & $\mathbf{1 , 6 9}$ & 17,0 & $\mathbf{1 , 5 9}$ \\
\hline $0,125-0,25$ & 49,5 & $\mathbf{1 , 4 2}$ & 19,0 & $\mathbf{1 , 4 5}$ & 12,9 & $\mathbf{1 , 9 7}$ \\
\hline $0,063-0,125$ & 7,4 & $\mathbf{1 , 5 6}$ & 3,6 & $\mathbf{1 , 4}$ & 8,0 & $\mathbf{1 , 6 1}$ \\
\hline Viso užpildo & 100 & $\mathbf{1 , 4 0}$ & 100 & $\mathbf{1 , 4 4}$ & 100 & $\mathbf{1 , 8 7}$ \\
\hline
\end{tabular}

2.7 ir 2.8 lentelèse pateiktų mišinių segregacijos rodikliai pateikti 3.11 paveiksle. Bazinès sudèties SPAB betonui $D_{1}-D_{2}=0 \mathrm{~cm}, h=4,2 \mathrm{~cm}$ ir šiuo atveju gaunamas segregacijos rodiklis $W=0$, nusakantis geros konsistencijos mišinị.

Užpildų mišinių pailgumo indeksų priklausomybė nuo segregacijos rodiklių pateikta 3.12 paveiksle. Užpildų mišinio dalelių pailgumo indeksas gali būti apskaičiuojamas kaip suma atskirų frakcijų pailgumo indeksų, dauginant iš frakcijos kiekio:

$$
I_{\text {sum }}=I_{1} \cdot p_{1}+I_{2} \cdot p_{2} \ldots,
$$

čia, $I_{1,2}$ - frakcijos dalelių pailgumo indeksas, $p_{1,2}-$ frakcijos procentinè dalis 
3.13 paveiksle pateiktas mišinių suslūgimas $h$, o 3.14 ir 3.15 paveiksluose cementinès tešlos ir matricos pasklidimai $D_{1}, D_{2}$. 3.16 ir 3.17 paveiksluose pateikiamos konsistencijos bandymų nuotraukos. Analizuodami rezultatus matome, kad didinant alternatyvių užpildų kiekį, segregacijos rodiklis didejja ir mišinio konsistencija blogejja. Visais atvejais geresnè konsistencija gauta naudojant ịprastinio smèlio užpildą, negu granito atsijas.

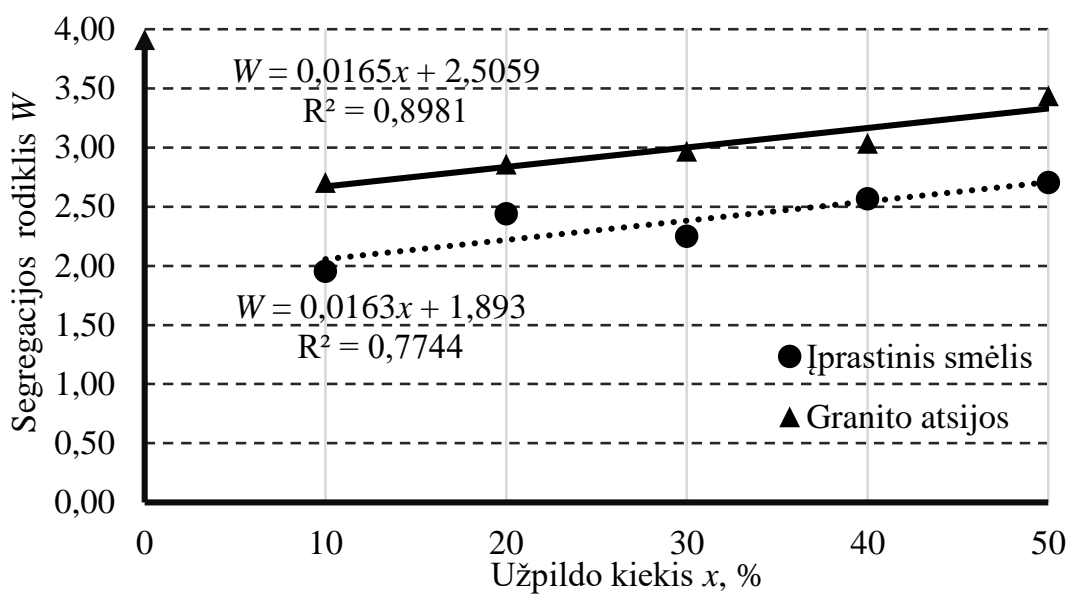

3.11 pav. Segregacijos rodiklio $W$ priklausomybè nuo užpildų kiekio bei tipo Fig. 3.11. Workability indexes $W$ for compositions with different aggregates quantities

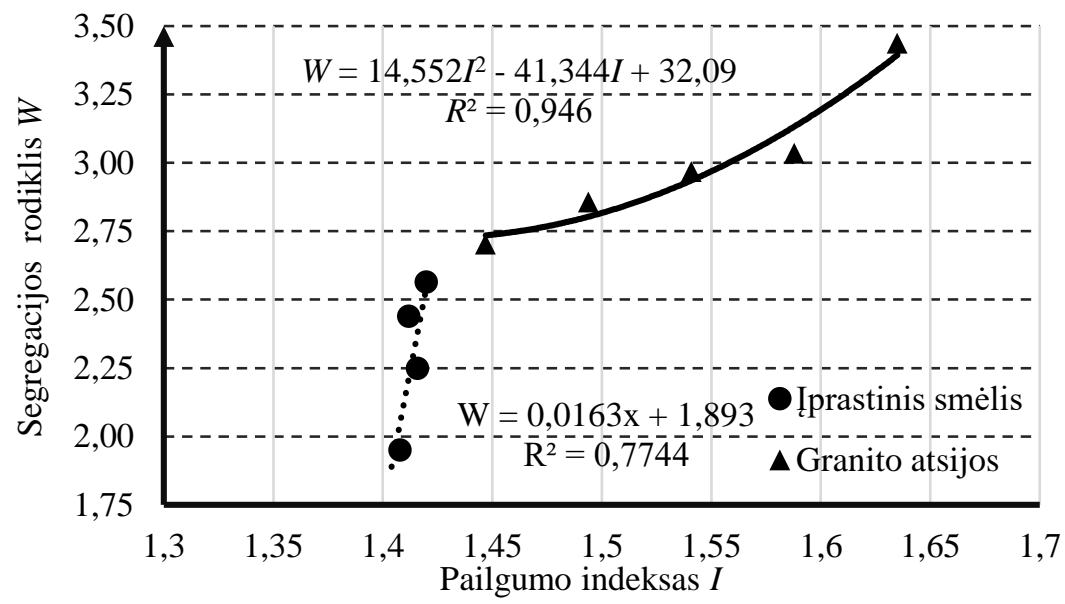

3.12 pav. Segregacijos rodiklio $W$ priklausomybe nuo užpildų mišinio dalelių pailgumo indekso $I$

Fig. 3.12. Dependence of the segregation index $W$ on the particle elongation index $I$ of the aggregate mixture 


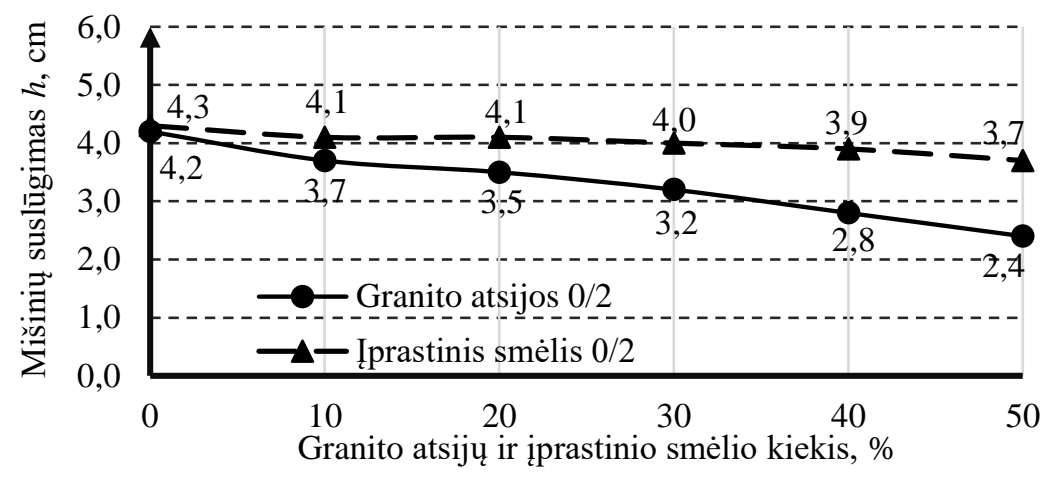

3.13 pav. Mišinių suslūgimas (Sutardo viskozimetro aukštis)

Fig. 3.13. Concrete mix slump (Sutard viscosymeter heith)

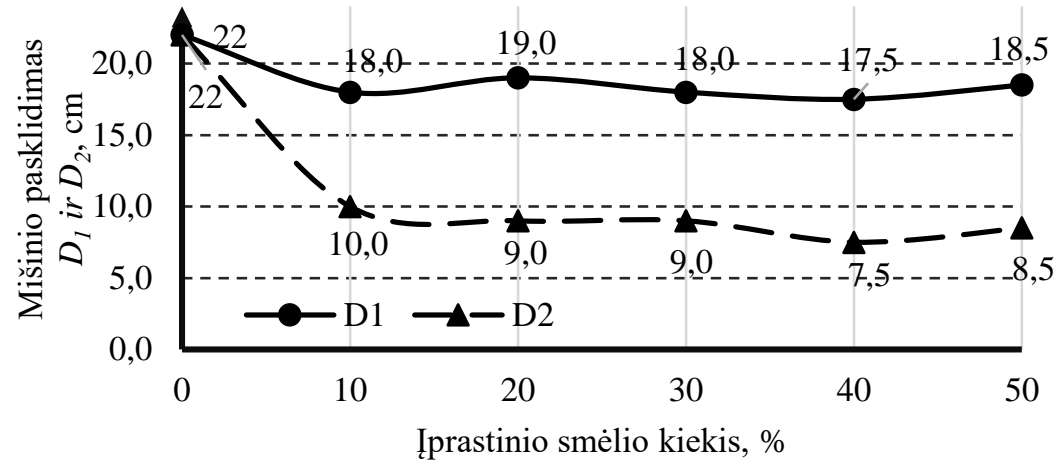

3.14 pav. Mišinio pasklidimas $D_{1}$ ir $D_{2}$ su ịprastiniu smèliu

Fig. 3.14. Concrete mix spread $D_{1}$ and $D_{2}$ for compositions with regular sand

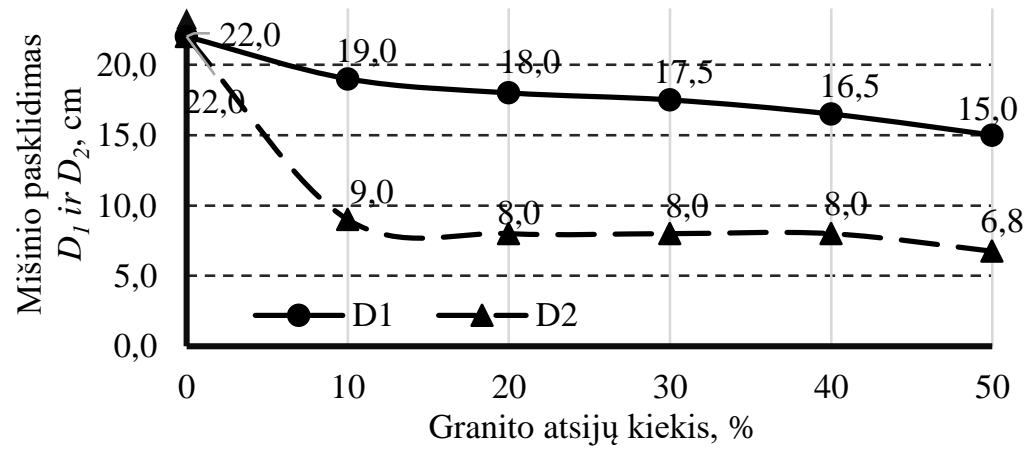

3.15 pav. Mišinio pasklidimas $D_{1}$ ir $D_{2}$ su granito atsijomis

Fig. 3.15. Concrete mix spread $D_{1}$ and $D_{2}$ for compositions with crushed granite 


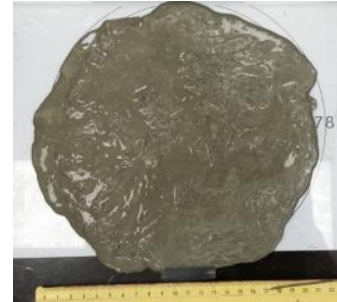

a)

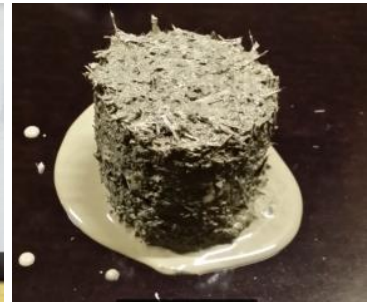

b)

3.16 pav. Konsistencijos bandymų nuotraukos: a) mišinio pasklidimas (100 \% kvarcinis smèlis); b) mišinio suslūgimas (100\% granito atsijos)

Fig. 3.16. Fotos of workability tests: a) referential quartz matrix (100\% quartz filler); b) $100 \%$ granite filler

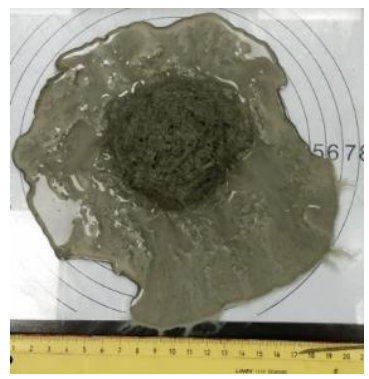

a)

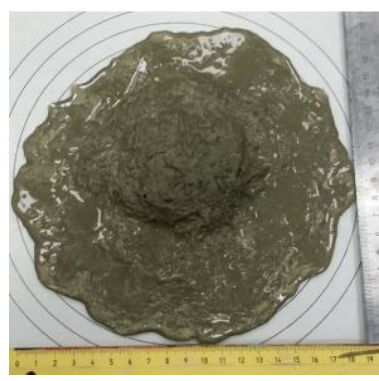

b)

3.17 pav. Konsistencijos bandymų nuotraukos: a) $50 \%$ kvarco pakeista granitu;

b) $50 \%$ kvarco pakeista ịprastiniu smèliu

Fig. 3.17. Fotos of workability tests: a) $50 \%$ quartz replaced with granite;

b) $50 \%$ quartz replaced with regular sand

Iš atliktų mokslinių tyrimų su ịprastiniais betonais yra žinoma, kad užpildo dalelių forma ir užpildo paviršiaus charakteristikos yra svarbus veiksnys, lemiantis betono mišinio vandens ir cemento santykị - kuo didesnis dalelių paviršiaus plotas, tuo didesnio kiekio vandens reikia norint gauti reikiamos konsitencijos betono mišinị (Soni ir Shukla, 2021). Kampuotos dalelès gali padidinti betono gniuždymo stiprị, tačiau blogèja mišinio konsistencija (Cordeiro et al., 2016).

Šiuose tyrimuose naudoto kvarcinio smèlio dalelèms būdinga sferinè forma, glotniais paviršiais, dèl ko gaunama mažesnè trintis tarp cementinès matricos, užpildo bei plaušo (3.18a pav.). Granito atsijų dalelèms būdinga plokštelių forma su aštriomis briaunomis, dèl ko padidèja vidinè trintis matricoje, plaušas užstringa tarp stambesnių dalelių, o smulkios dalelès prateka pro tarpus kartu su cementiniu skiediniu (3.18b pav.). Iprastinio smèlio užpildo dalelès netaisyklingų erdvinių daugiakampių formos, todèl mišinių konsistencijos parametrai artimesni sudètims su granito užpildu. 


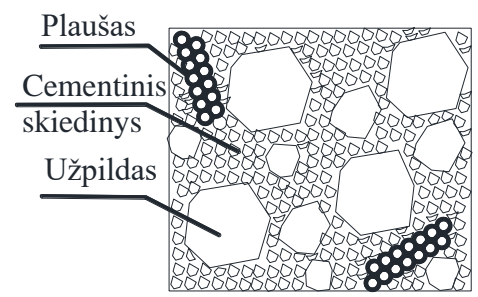

a)

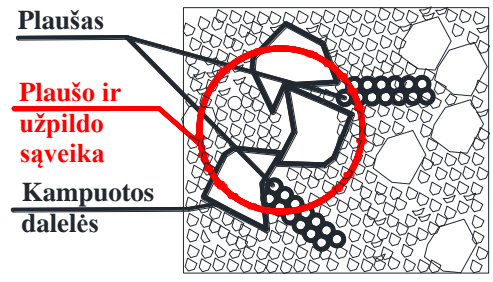

b)

3.18 pav. Smulkiagrūdžio betono matricos schemos: a) su taisyklingų formų kvarco užpildu b) plaušo saveika su užpildu, esant netaisyklingos formos užpildo dalelių (sudaryta autoriaus)

Fig. 3.18. Schemes of fine-grained concrete matrix: a) typical matrix with round shaped quartz filler b) crowding effect of fibers when sharp edged particles are introduced

(made by author)

Kaip parodè mišinių konsistencijos ir segregacijos tyrimų rezultatai, SPAB betono mišinio konsistencija ir segregacija priklauso nuo užpildo dalelių formos. Mokslininkų sukurta nemažai dalelių formą apibūdinančių parametrų, kurie naudojami skaitmeniniame dalelių mišinio tankio modeliavime (Blott et al., 2007). Tačiau kiti mokslininkai siūlo naudoti supaprastintus formos rodiklius (sferiškumas, plokštumas bei pailgumas), nagrinejjant betono mišinių konsistencijos problemas (Zheng et al., 2015), todèl šiame darbe tokiu parametru pasirinktas pailgumo indeksas, kuri galima nustatyti paprastomis vizualinèmis priemonèmis mikroskopu darytomis nuotraukomis ir braižymo programomis. Užpildo dalelių pailgumo indeksui padidejus vos $3 \%$ mišinio pasklidimas sumažèja $10 \%$, kai vietoje kvarcinio smėlio naudojamas ịprastinis smèlis. Kai naudojamas netaisyklingos formos užpildas (granito atsijos), dalelių pailgumo indeksas lyginant su kvarciniu smèliu padidèja $33 \%$, o mišinio pasklidimas atitinkamai sumažèja iki $50 \%$. Didinant iprastinio smèlio kieki nuo $10 \%$ iki $50 \%$, segregacijos rodiklis didèja nuo 1,9 iki 2,6, o naudojant granito atsijas atitinkamai nuo 2,6 iki 3,5.

Ivertinus šiuos parametrus, galima teigti, kad SPAB betonui labiau rinka užpildai, kuriuose vyrauja sferinès formos dalelès, užtikrinančios tolygų cementinės matricos ir plaušo pasklidimą.

\subsubsection{Aktyvių mineralinių priedų poveikis stiklo plaušu armuotų mišinių konsistencijai}

$\mathrm{SiO}_{2}$ mikrodulkių ir metakaolino mineralinių priedų vidutinis dalelių dydis neviršija portlandcemenčio CEM I 52,5R, todèl pagal struktūrą juos galima priskirti cementinei fazei. Didinant cementinès fazès kieki mišinyje, bendra sistemos 
klampa didejja ir norint išlaikyti pradinę mišinio konsistenciją, reikia didinti vandens arba plastiklio kiekị.

Šiame tyrime panaudotų aktyvių mineralinių priedų kiekis buvo $2,5 \%, 5 \%$ ir $7,5 \%$ nuo cemento masès, arba $23 \mathrm{~kg} / \mathrm{m}^{3}, 46 \mathrm{~kg} / \mathrm{m}^{3}, 69 \mathrm{~kg} / \mathrm{m}^{3}$ betono mišinio. Pradinis vandens ir plastiklio kiekis nebuvo keičiamas, todèl 3.19 paveiksle pateikti rezultatai atspindi šių priedų poveikị mišinio konsistencijai. Kaip matome, panaudojus iki 7,5\% $\mathrm{SiO}_{2}$ mikrodulkių, mišinio pasklidimas sumažejo nuo $19 \mathrm{~cm}$ iki $13 \mathrm{~cm}(31 \%)$, o su 7,5\% metakaolino iki $15 \mathrm{~cm}(21 \%)$.

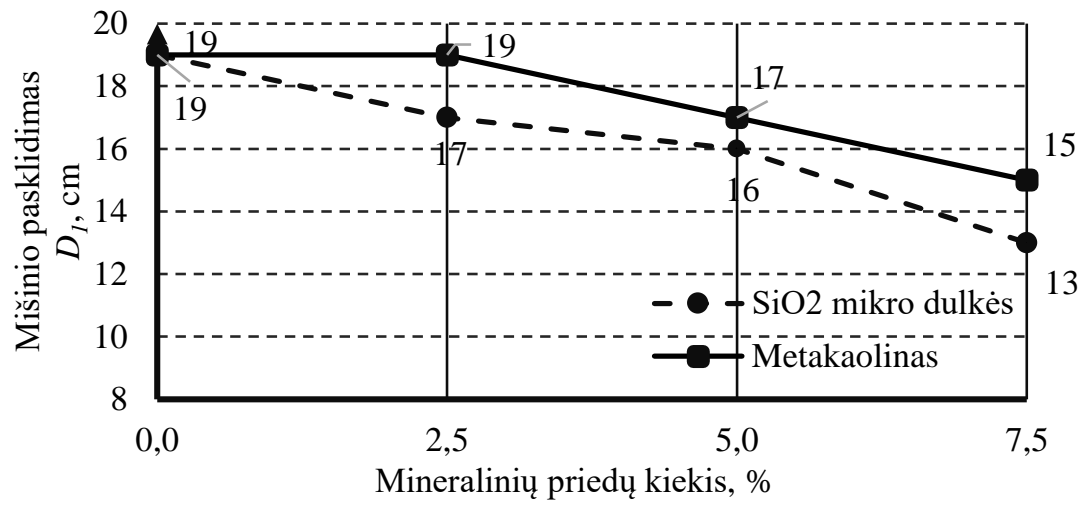

3.19 pav. Mineralinių priedų poveikis SPAB mišinių pasklidimui $\left(D_{1}\right)$

Fig. 3.19. Impact of mineral additives on GRC mix spread $\left(D_{1}\right)$

Flores (2017) ištyrè, kad naudojant už cementą smulkesnių dalelių mikroužpildus, sumažèja cemento skiedinių pasklidimas. Norint kompensuoti pasklidimo sumažèjimą, reikètų didinti superplastiklio kiekį. Aktyvių mineralinių priedų poveikis konsistencijai labiausiai priklauso nuo priedo dalelių dydžio ir savitojo paviršiaus ploto (metakaolinui - $11000 \mathrm{~m}^{2} / \mathrm{g}, \mathrm{SiO}_{2}$ mikrodulkèms $-18000 \mathrm{~m}^{2} / \mathrm{kg}$ (Aghabaglou et al., 2014). Kuo mažesnès dalelès, tuo didesnio kiekio vandens reikia jų surišimui. Tuo galima paaiškinti šiame tyrime pastebètą $\mathrm{SiO}_{2}$ mikrodulkių didesnị poveikị mišinių pasklidimui, kurių dalelių paviršiaus plotas yra didesnis nei metakaolino.

\subsection{Stiklo plaušu armuoto betono fizikinių bei mechaninių savybių tyrimai}

Atlikus betono mišinių su skirtingais užpildais tankio tyrimus nustatyta, kad mišinių tankis tolygiai didèjo didinant granito ir ịprastinio smèlio užpildų kiekius 
(3.20 pav.). Mažiausia gauta reikšmė $-2190 \mathrm{~kg} / \mathrm{m}^{3}$ (bazinès sudèties), didžiausios - su $50 \%$ granito ir su $50 \%$ iprastinio smèlio, atitinkamai $2221 \mathrm{~kg} / \mathrm{m}^{3}$ $(+1,4 \%)$ ir $2242 \mathrm{~kg} / \mathrm{m}^{3}(+2,4 \%)$.

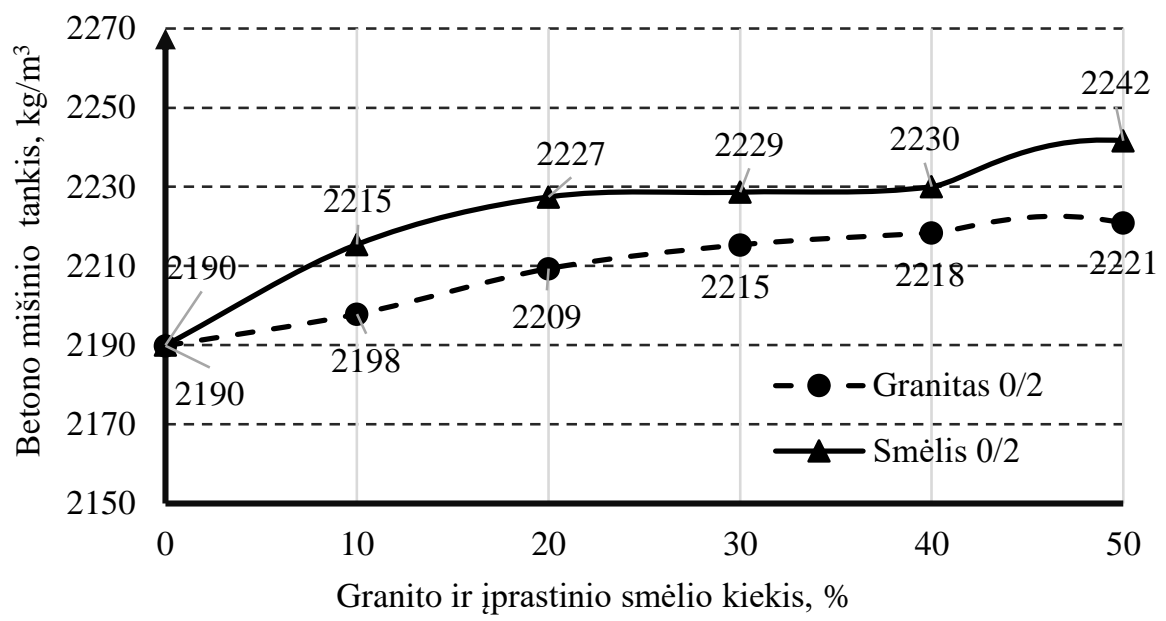

3.20 pav. Smulkiagrūdžio stiklo plaušu armuoto betono mišinio tankiai pakeičiant iki $50 \%$ kvarco granito bei ịprastinio smèlio užpildais

Fig. 3.20. Fine-grained glass fiber reinforced concrete mix densities replacing up to $50 \%$ quartz filler with granite and regular sand

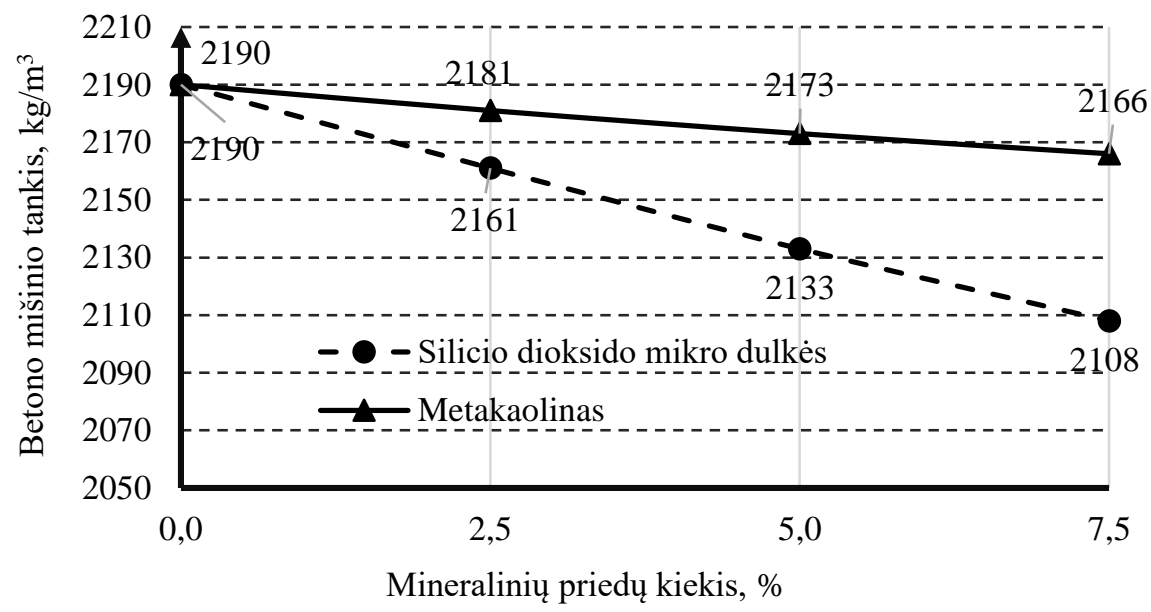

3.21 pav. Aktyvių mineralinių priedų poveikis smulkiagrūdžio stiklo plaušu armuoto betono mišinio tankiui

Fig. 3.21. Impact of active mineral additives to fine-grained glass fiber reinforced concrete mix densities 
Mineralinių priedų poveikis SPAB betono mišinio tankiui buvo žymiai didesnis negu dalies kvarco pakeitimas granitu bei ịprastiniu smèliu. Betono mišinio tankiai su mineraliniais priedais pateikti 3.21 paveiksle. Pradinis mišinio tankis $2190 \mathrm{~kg} / \mathrm{m}^{3}$ tolygiai mažejo panaudojus $\mathrm{SiO}_{2}$ bei metakaolino priedus, atitinkamai iki $2108 \mathrm{~kg} / \mathrm{m}^{3}(-3,7 \%)$ ir $2166 \mathrm{~kg} / \mathrm{m}^{3}(-1,1 \%)$.

Stipruminių savybių tyrimų rezultatai parode, kad bazinio SPAB kompozito su kvarciniu smèliu vidutinis lenkimo stipris - 13,3 MPa, o gniuždymo $82,9 \mathrm{MPa}$, kai bandiniai - $40 \mathrm{~mm}$ storio prizmès. Pakeitus bandinius i $15 \mathrm{~mm}$ storio plokšteles, gautas lenkimo stiprio sumažejimas iki 10,2 MPa, o kai bandiniai $100 \times 100 \times 100 \mathrm{~mm}$ kubeliai, gniuždymo stipris sumažeja iki 74,2 MPa. Tai gali būti paaiškinama didesniu horizontalia kryptimi išsidèsčiusių plaušelių kiekiu storesniame bandinio skerspjūvyje.

Atlikus lenkimo stiprio tyrimus su skirtingais užpildais nustatyta, kad pakeitus iki $50 \%$ kvarcinio smèlio granito atsijomis, vidutinis lenkimo stipris sumažejja $10,3 \%$ (iki 11,92 MPa). Vietoje granito atsijų panaudojus ịprastinị smèlị, lenkimo stipris sumažèja 3,4 \% (iki 12,84 MPa) (3.22 pav. ir 3.23 pav.). Lenkimo stiprio nustatymui buvo naudojamos $40 \times 40 \times 140 \mathrm{~mm}$ matmenų prizmès.

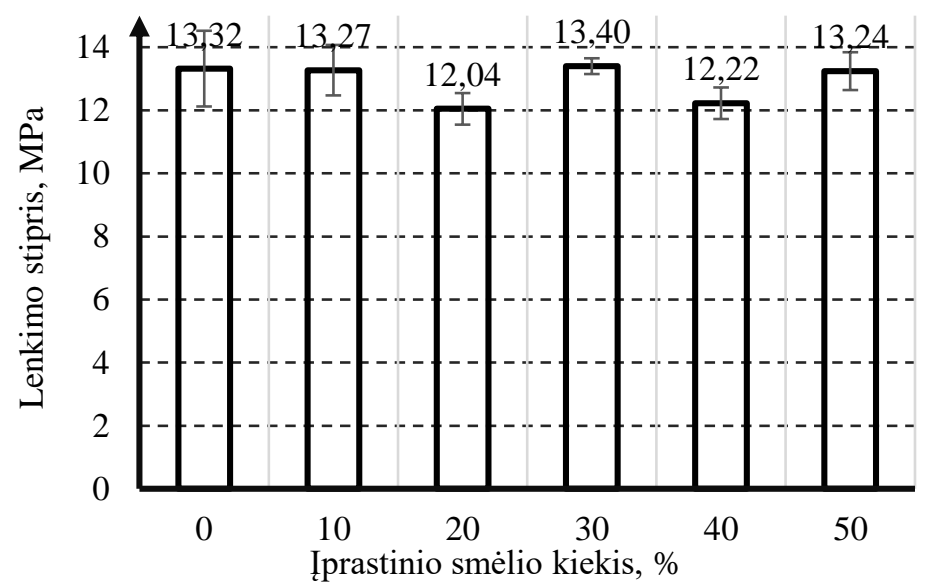

3.22 pav. Užpildų poveikis smulkiagrūdžio stiklo plaušu armuoto betono lenkimo stipriui, dalị kvarcinio smèlio pakeičiant ịprastiniu smèliu

Fig. 3.22. Impact of aggregates on flexural strength of fine-grained glass fiber reinforced concrete. Part of quartz sand is substituted by regular sand 


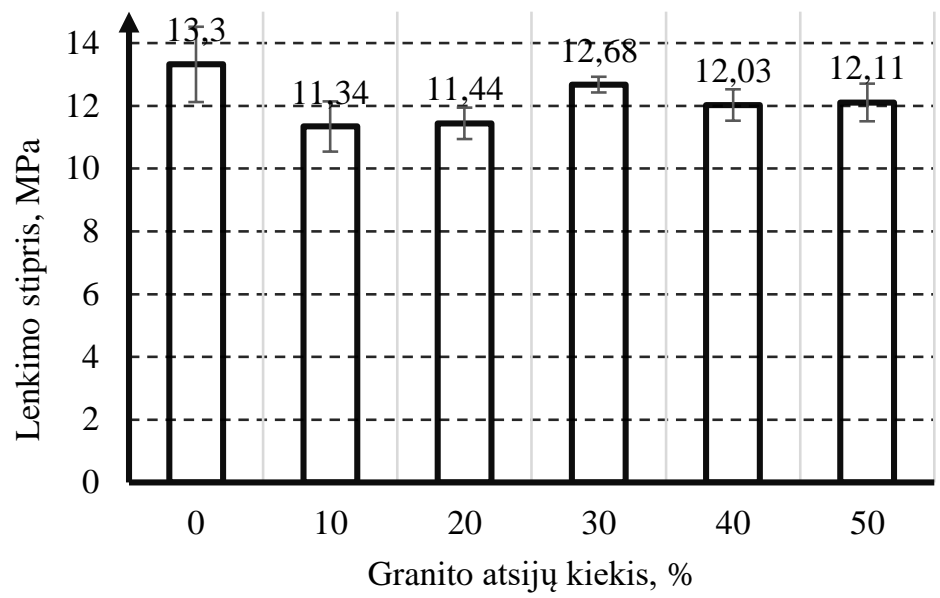

3.23 pav. Užpildų poveikis smulkiagrūdžio stiklo plaušu armuoto betono lenkimo stipriui dali kvarcinio smèlio pakeičiant granito atsijomis

Fig. 3.23. Impact of aggregates on flexural strength of fine-grained glass fiber reinforced concrete. Part of quartz sand is substituted by granite

Atlikus gniuždymo stiprio tyrimus su skirtingais užpildais nustatyta, kad pakeitus iki $50 \%$ kvarcinio smėlio granito atsijomis, gniuždymo stipris sumažèja $7 \%$ (iki 76,8 MPa). Vietoje granito atsijų panaudojus ịprastinị smèlį, gniuždymo stipris sumažeja $23 \%$ (iki 63,5 MPa) (3.24 pav. ir 3.25 pav.). Gniuždymo stiprio nustatymui buvo naudojamos $40 \times 40 \times 140 \mathrm{~mm}$ matmenų prizmès.

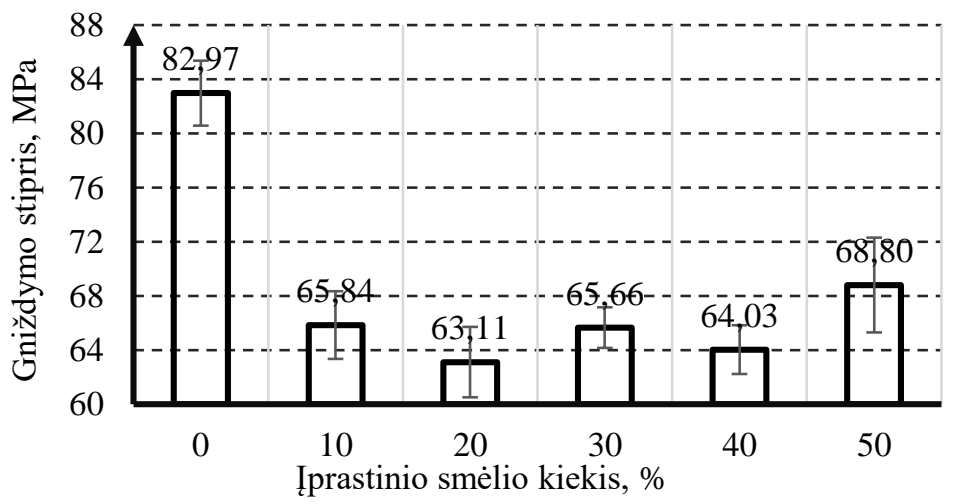

3.24 pav. Užpildų poveikis smulkiagrūdžio stiklo plaušu armuoto betono gniuždymo stipriui, dalị kvarcinio smèlio pakeičiant ịprastiniu smèliu

Fig. 3.24. Impact of aggregates on compressive strength of fine-grained glass fiber reinforced concrete. Part of quartz sand is substituted by regular sand 


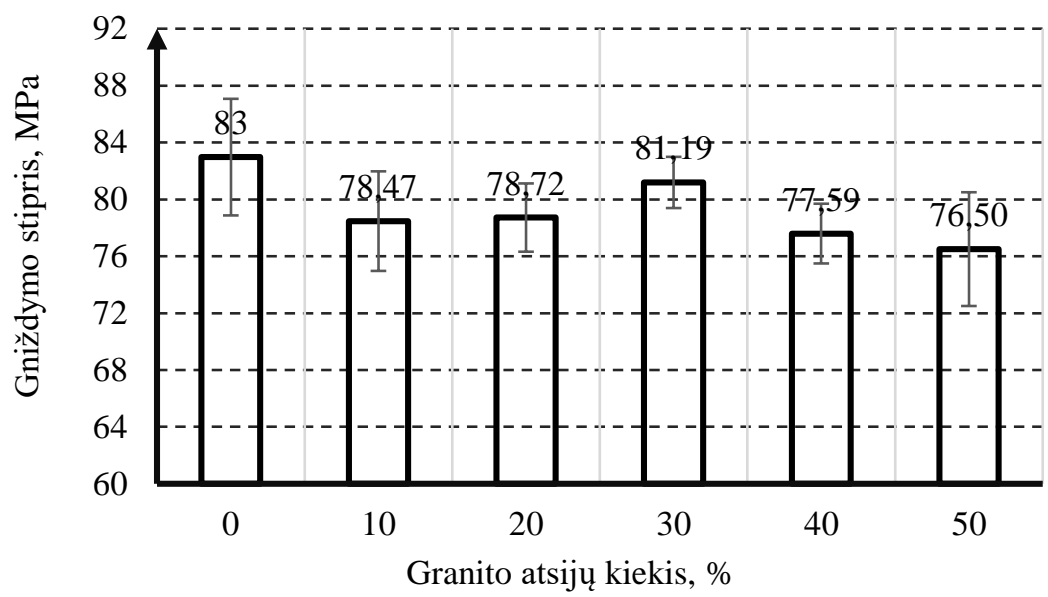

3.25 pav. Užpildų poveikis smulkiagrūdžio stiklo plaušu armuoto betono gniuždymo stipriui dalị kvarcinio smėlio pakeičiant granito atsijomis

Fig. 3.25. Impact of aggregates on compressive strength of fine-grained glass fiber reinforced concrete. Part of quartz sand is substituted by granite

Taip pat buvo atlikti tyrimai su skirtingu aktyvių mineralinių priedų kiekiu $2,5 \%, 5 \%$ ir $7,5 \%$ metakaolino bei $\mathrm{SiO}_{2}$ mikrodulkių. Dozuojant priedus iki $7,5 \%$ nuo cemento masès, didelio poveikio lenkimo stipriui nenustatyta. Bandinių su $\mathrm{SiO}_{2}$ mikrodulkèmis stiprumas svyravo tarp 9,1-10,6 MPa, kur mažiausia reikšmė buvo gauta su $5 \%$ priedo. Metakaolinas turèjo dar mažesnę ịtaką, gauti rezultatai svyravo tarp 10,3-10,7 $\mathrm{MPa}$ (3.26 pav. ir 3.27 pav.).

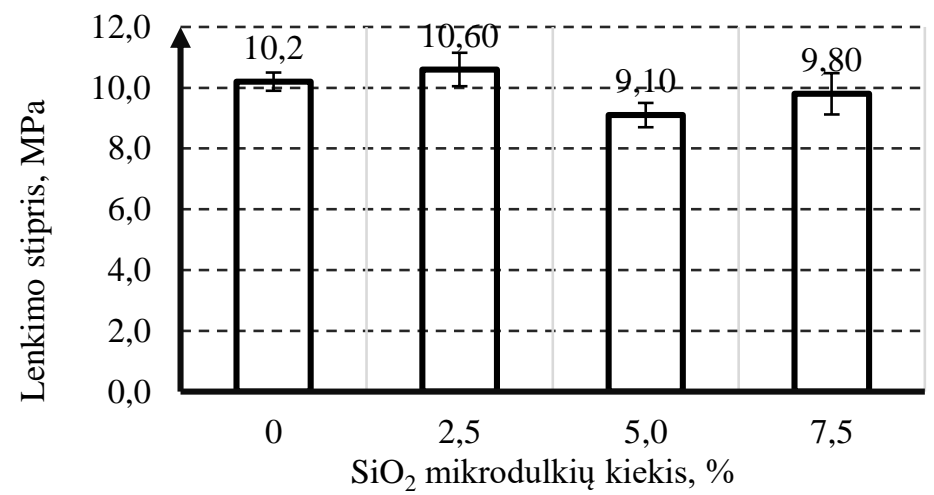

3.26 pav. $\mathrm{SiO}_{2}$ mikrodulkių poveikis smulkiagrūdžio stiklo plaušu armuoto betono lenkimo stipriui

Fig. 3.26. Impact of silica fume on flexural capacity of fine-grained glass fiber reinforced concrete 


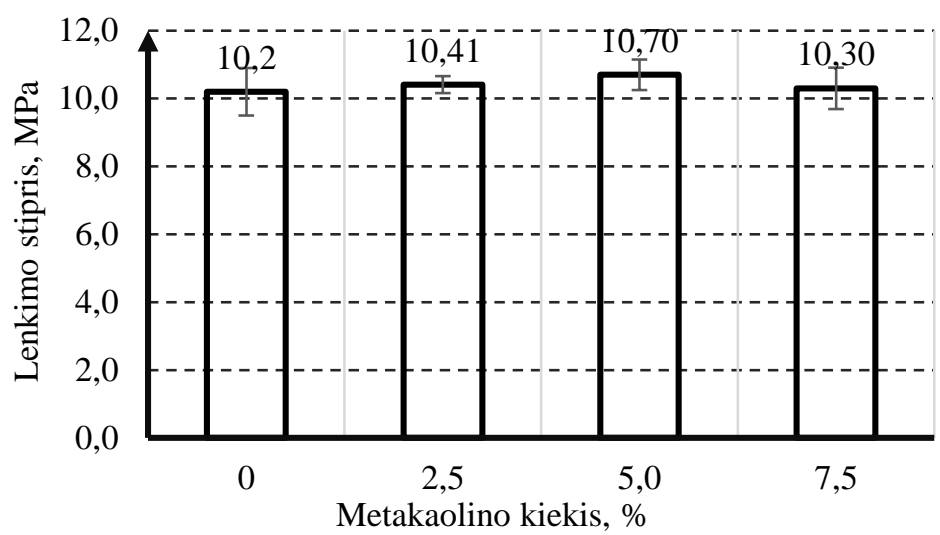

3.27 pav. Metakaolino poveikis smulkiagrūdžio stiklo plaušu armuoto betono lenkimo stipriui

Fig. 3.27. Impact of metakaolin on flexural capacity of fine-grained glass fiber reinforced concrete

$\mathrm{SPAB}$ kompozito gniuždymo stipris padidèjo, $\mathrm{kai} \mathrm{SiO}_{2}$ mikrodulkių ir metakaolino naudojama ne mažiau nuo 7,5 \% nuo cemento masès. Didžiausia gniuždymo stiprio reikšmė su 7,5 \% priedo kiekiu, atitinkamai $78 \mathrm{MPa}$ ir $77 \mathrm{MPa}$. Mažesnis šių priedų kiekis sumažina SPAB kompozito gniuždymo stiprị iki $67 \mathrm{MPa}$ (3.28 pav. ir 3.29 pav.).

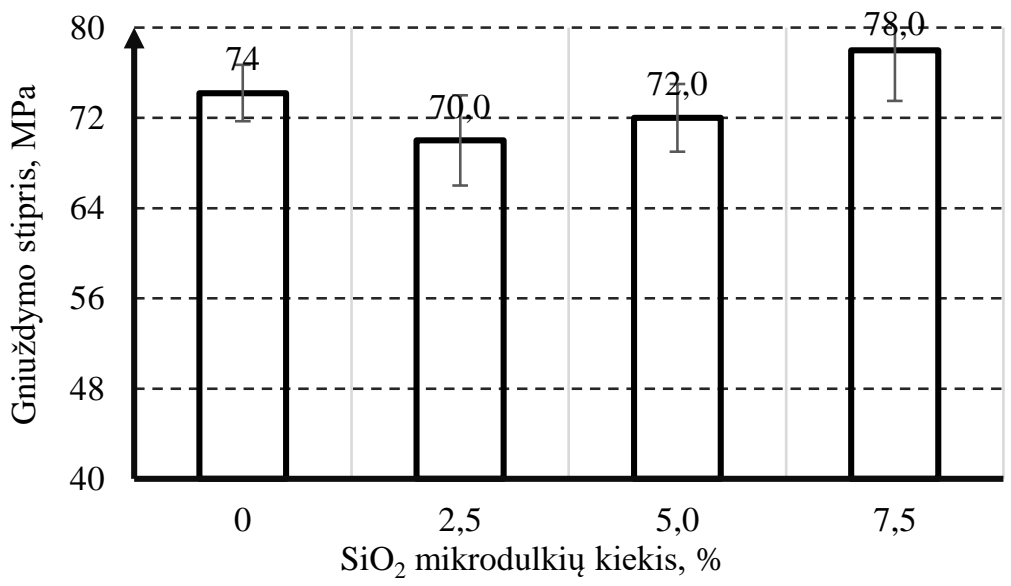

3.28 pav. $\mathrm{SiO}_{2}$ mikrodulkiu poveikis smulkiagrūdžio stiklo plaušu armuoto betono gniuždymo stipriui

Fig. 3.28. Impact of silica fume on compressive strenght of fine-grained glass fiber reinforced concrete 


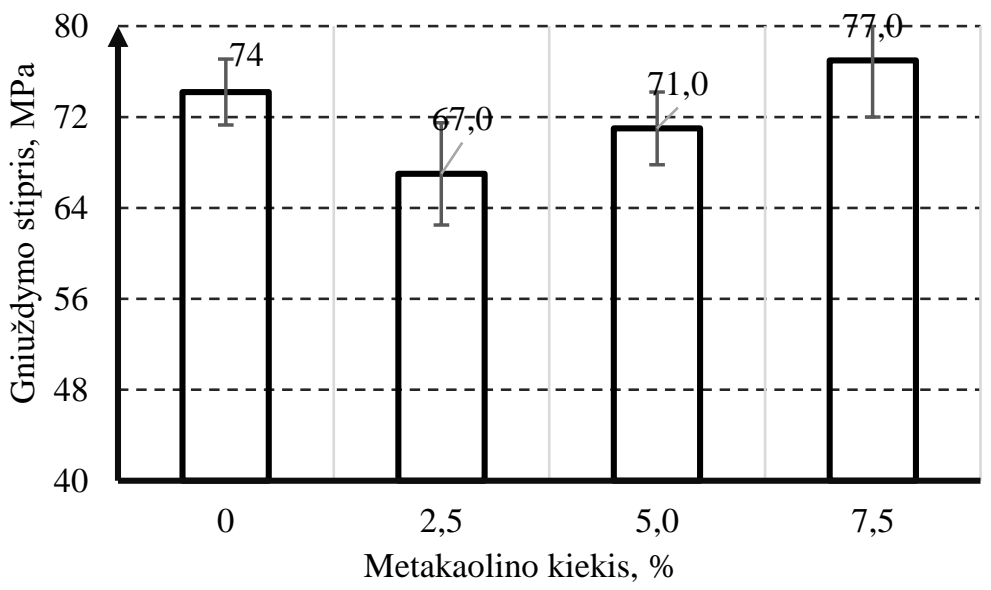

3.29 pav. Metakaolino poveikis smulkiagrūdžio stiklo plaušu armuoto betono gniuždymo stipriui

Fig. 3.29. Impact of metakaolin on compressive strenght of fine-grained glass fiber reinforced concrete

Pagal gautus duomenis, SPAB kompozitui būdingas didelis gniuždymo stipris (70-80 MPa), o plonasienių gaminių mechaninių savybių tyrimams rekomenduotina naudoti plonas plokšteles, artimo storio realiam gaminiui dèl didelès bandinio mastelio itakos rezultatams $(>30 \%)$. Panaudojus iprastas skiedinių prizmeles $40 \times 40 \times 160 \mathrm{~mm}$, galimi dideli nukrypimai nuo realaus storio gaminio dèl skirtingo plaušelių išsidèstymo liejant betoną i formas.

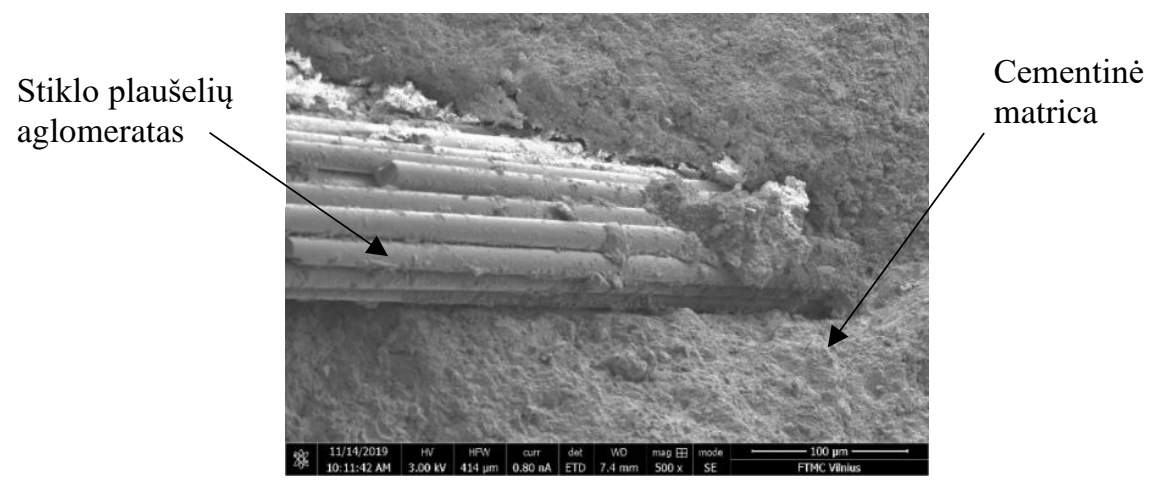

3.30 pav. Stiklo plaušelių išsidèstymas cementinèje matricoje, didinimas 500x.

Fig. 3.30. Glass fiber possitioning in cementititous matrix, magnification 500x. 


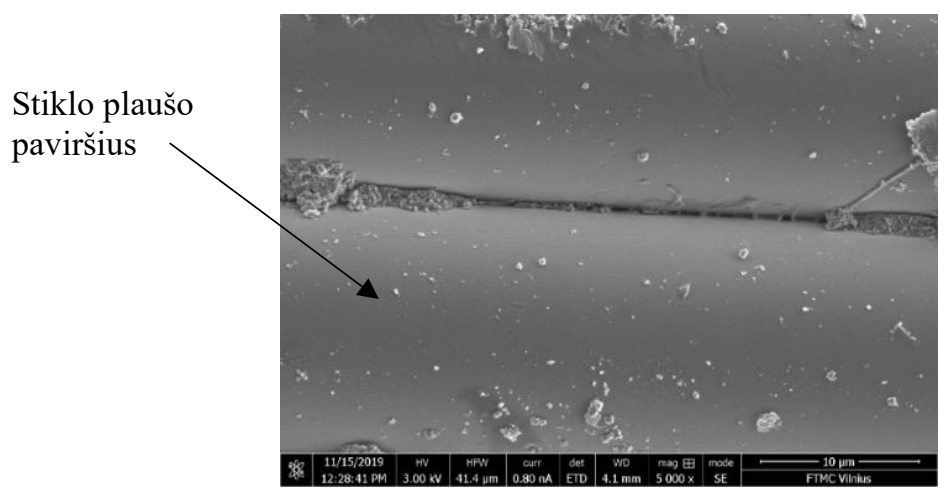

3.31 pav. Stiklo plaušo kontaktinis paviršius, didinimas 5000x.

Fig. 3.31. Glass filament surface, magnification 5000x.

Išbandytų bandinių lūžio paviršiai buvo ištirti skenuojančiu elektroniniu mikroskopu. Visų bandinių amžius tyrimo metu buvo 9 ménesiai po suformavimo. Stiklo pluoštas sudarytas iš pavienių plaušelių, kurie tarpusavyje nèra chemiškai sulipinti ir tempimo įtempius išoriniai sluoksniai vidiniams perduoda trintimi ar dèl elektrostatinès traukos jègų (3.30 pav.), stiklo plaušelių paviršius - lygus, be defektų (3.31 pav.).

\subsection{Stiklo plaušu armuoto betono atsparumas šalčiui}

Atsparumo šalčiui tyrimuose panaudota sudètis su stiklo plaušu, kurio pasirinkimas pagrịstas ankstesniame skyriuje (S1). Matricos struktūros modifikavimui panaudoti mineraliniai priedai - $\mathrm{SiO}_{2}$ mikrodulkès ir metakaolinas, kuriu kiekiai buvo $0 \%, 2,5 \%, 5 \%, 7,5 \%$ nuo cemento masès (sudètys MS1, MS2, MS3, MK1, MK2, MK3).

Kai betonas yra veikiamas šalčio, vanduo esantis porose virsta ledo kristalais, taip padidindamas betono tūrị iki $9 \%$. Išsiplètimas vyksta dẻl didejjančio hidraulinio slègio ir osmosinių reiškinių porose, kurie abu yra atsakingi už mikroplyšių susidarymą. Norint pasiekti geresni atsparumą šalčiui, reikia optimizuoti cementinès matricos poringumą ir padidinti betono vandens nepralaidumą. Tuo tikslu dažnai yra naudojami aktyvūs mineraliniai priedai, kuriems būdingos pucolaninės reakcijos (Pigeon et al., 2010; Mehta et al., 2006).

Shon nustatè, kad jei mažesnès nei $300 \mu \mathrm{m}$ oro poros yra tolygiai pasiskirsčiusios cementinio akmens tūryje, jos vaidina svarbų vaidmeni kaip rezervuarai, sugeriantys vidinius įtempius dèl augančių ledo kristalų (Shon et al., 2018). Kad betonas būtų atsparus šalčiui, taip pat yra labai svarbus atstumas nuo besiformuo- 
jančio ledo kristalo iki ertmès kur jis galètų augti. Pigeon (2010) pasiūlè tai charakterizuoti porų išsidèstymo rodikliu, nusakančiu minimalų atstumą tarp cementinès matricos porų. Apibendrinant, galima teigti, kad užšaldymo ir atšildymo ciklams atsparus betonas turi optimalų porų dydžio ir atstumo tarp jų santykį, kuris skirtingos sudèties ir mikrostruktūros betonams gali labai skirtis.

Mokslininkų nustatyta, naudojant ne daugiau kaip $20 \% \mathrm{SiO}_{2}$ mikrodulkių priedo nuo cemento masès, gaunamas pakankamai geras betono atsparumas šalčiui. Kadangi $\mathrm{SiO}_{2}$ mikrodulkių dalelių dydis yra iki 100 kartų mažesnis nei cemento, tokiu būdu jos išsidèsto tarp cemento dalelių ir padidina cementinio akmens tankį. Dèl pucolaninių reakcijų sumažèja cementinio akmens kapiliarinè absorbcija, pasikeičia matricos poringumas (Gruszczyński et al., 2020; Emamian et al., 2020). Metakaolino dalelès yra apie 10 kartų mažesnès nei cemento ir pagrindinè sudedamoji dalis yra $\mathrm{SiO}_{2}$. Šiam priedui būdingos panašios pucolaninės reakcijos su cementu kaip ir $\mathrm{SiO}_{2}$ mikrodulkèms. Pucolaninių reakcijų metu naujai susiformavęs tankios struktūros CSH gelis užpildo tarpus tarp cemento dalelių, todèl cementinè matrica tampa tankesne, bendras betono porų tūris ir porų dydis sumažèja (Sharma et al., 2018; Nicolas et al., 2014).

\subsection{1. [traukto oro kiekis betono mišinyje}

Betono atsparumas šalčiui dažnai vertinamas pagal įtraukto oro kieki mišinyje. Nustatyta, kad itraukto oro kiekis SPAB mišinyje be mikroužpildų yra 2,5\% ir kad $\mathrm{SiO}_{2}$ mikrodulkès bei metakaolinas ši rodiklị veikia skirtingai (3.32 pav.). Mišiniams su metakaolinu būdingas ịtraukto oro kiekio sumažejimas iki $2 \%$, o $\mathrm{SiO}_{2}$ mikrodulkès oro kieki padidino iki $4,7 \%$.

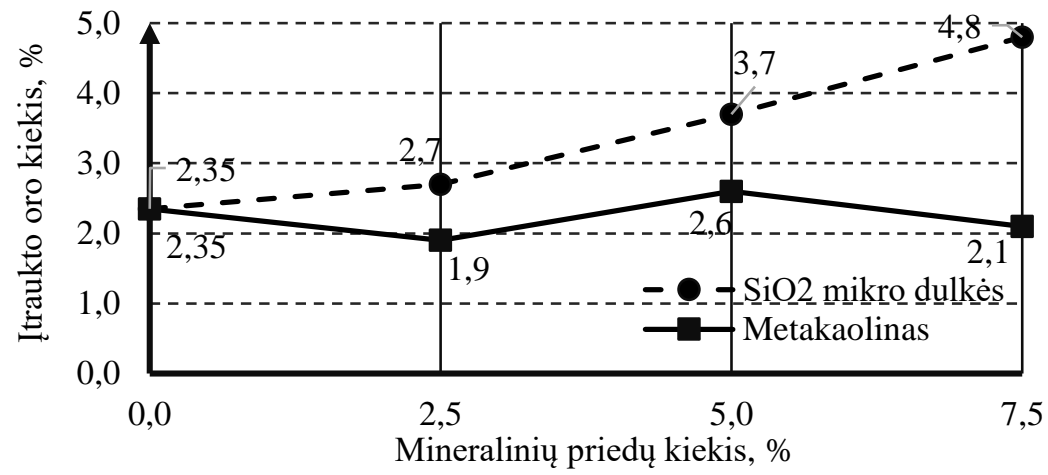

3.32 pav. Mineralinių priedų poveikis smulkiagrūdžio stiklo plaušu armuoto betono itraukto oro kiekiui

Fig. 3.32. Impact of mineral additives on entrained air of fine-grained glass fiber reinforced concrete 
Iprastinio betono praktikoje priimta, kad šalčiui atsparus betonas turètų turèti ne mažiau kaip $4 \%$ ịtraukto oro (LST 1974). Tačiau tankios struktūros kompozitų atveju su dideliu rišiklio bei smulkių dalelių kiekiu ši tendencija nebūtinai teisinga.

\subsubsection{Betono paviršiaus destrukcijos dèl užšaldymo ir atšildymo ciklų poveikio tyrimai}

Kadangi SPAB kompozitai yra dažniausiai naudojami kaip fasadų apdailos elementai, užšaldymo ir atšildymo ciklų poveikio sukelti pokyčiai betono paviršiuje yra viena esminių charakteristikų vertinant šio kompozito ilgaamžiškumą.

Standarte LST EN 15191 "Surenkamieji betono gaminiai. Stiklo pluoštu armuoto betono eksploatacinių charakteristikų klasifikavimas" nurodoma naudoti LST EN 13198 ,Surenkamieji betono gaminiai. Gatvių ir parkų tvarkymo elementai“ B priede aprašytą metodiką SPAB betono šalčio atsparumo vertinimui.

Atsparumo šalčiui bandymai atlikti su 7 skirtingomis betono sudètimis (S1, MS1, MS2, MS3, MK1, MK2, MK3) ir truko 112 paru, bandant pagal paviršinio šaldymo metodą, pateiktą LST EN13198 B priede, kur vieno pilno $+/-20{ }^{\circ} \mathrm{C}$ ciklo trukmè - 24 valandos. Suminiai atskilusios medžiagos nuo bandinių paviršiaus masès nuostoliai po 56 ir 112 ciklų pateikiami 3.33 ir 3.34 paveiksluose.

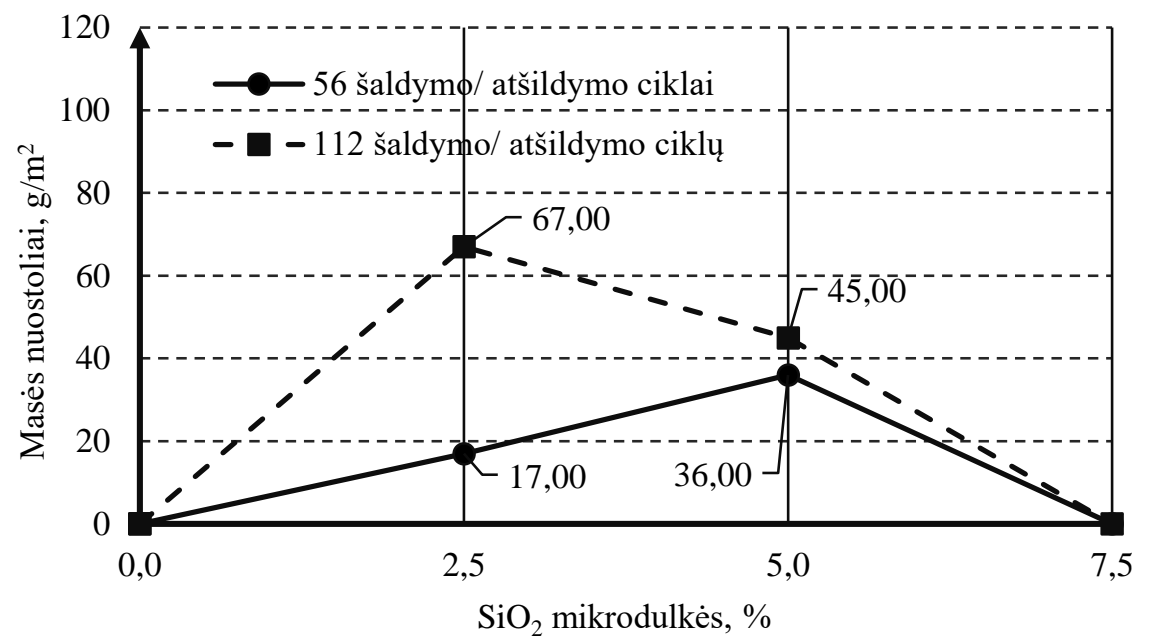

3.33 pav. $\mathrm{SiO}_{2}$ mikrodulkių poveikis smulkiagrūdžio stiklo plaušu armuoto betono paviršiniams masès nuostoliams, veikiant cikliškam šaldymui/atšildymui

Fig. 3.33. Impact of silica fume on scaling at freezing/thawing of fine-grained glass fiber reinforced concrete 
Pagal LST EN 13198, kai šalčio atsparumo bandymuose naudojamas $3 \%$ koncentracijos $\mathrm{NaCl}$ tirpalas, masès nuostoliai nuo betono paviršiaus neturètų viršyti $1500 \mathrm{~g} / \mathrm{m}^{2}$ po 28 užšaldymo ir šildymo ciklų. Visos tyrinètos sudettys tenkino standarto reikalavimus, kadangi masès nuostoliai nei vienoje iš jų neviršijo $500 \mathrm{~g} / \mathrm{m}^{2}$ po 112 ciklų.

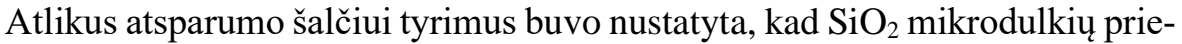
das turejjo nežymų poveikị paviršiniams masės nuostoliams, kuris galètų būti paaiškinamas dideliu ịtraukto oro kiekiu betono mišinyje. Didžiausia užfiksuota reikšmè $-67 \mathrm{~g} / \mathrm{m}^{2}$, su 2,5\% $\mathrm{SiO}_{2}$ priedo. Didinant $\mathrm{SiO}_{2}$ priedo kieki, įtraukto oro kiekis didejo, o masès nuostoliai mažèjo, atitinkamai iki $45 \mathrm{~g} / \mathrm{m}^{2}$ ir $0 \mathrm{~g} / \mathrm{m}^{2}$.

Metakaolino priedas turèjo didesnị poveikị betono paviršiaus pažeidimams. Kai šio priedo naudojama 2,5\% ir 5\%, masès nuostoliai po 112 ciklų buvo panašūs kaip ir sudètyse su $\mathrm{SiO}_{2}$ priedu ir neviršijo $50 \mathrm{~g} / \mathrm{m}^{2}$. Tačiau 7,5\% metakaolino priedo padidino masès nuostolius nuo betono paviršiaus, atitinkamai iki $115 \mathrm{~g} / \mathrm{m}^{2}$ po 56 ciklų ir iki $465 \mathrm{~g} / \mathrm{m}^{2}$ po 112 ciklų. Tai gali būti paaiškinama dideliu matricos tankiu dèl padidinto smulkių dalelių kiekio ir sumažejusio įtraukto oro kiekio betono mišinyje $(2,5 \%)$.

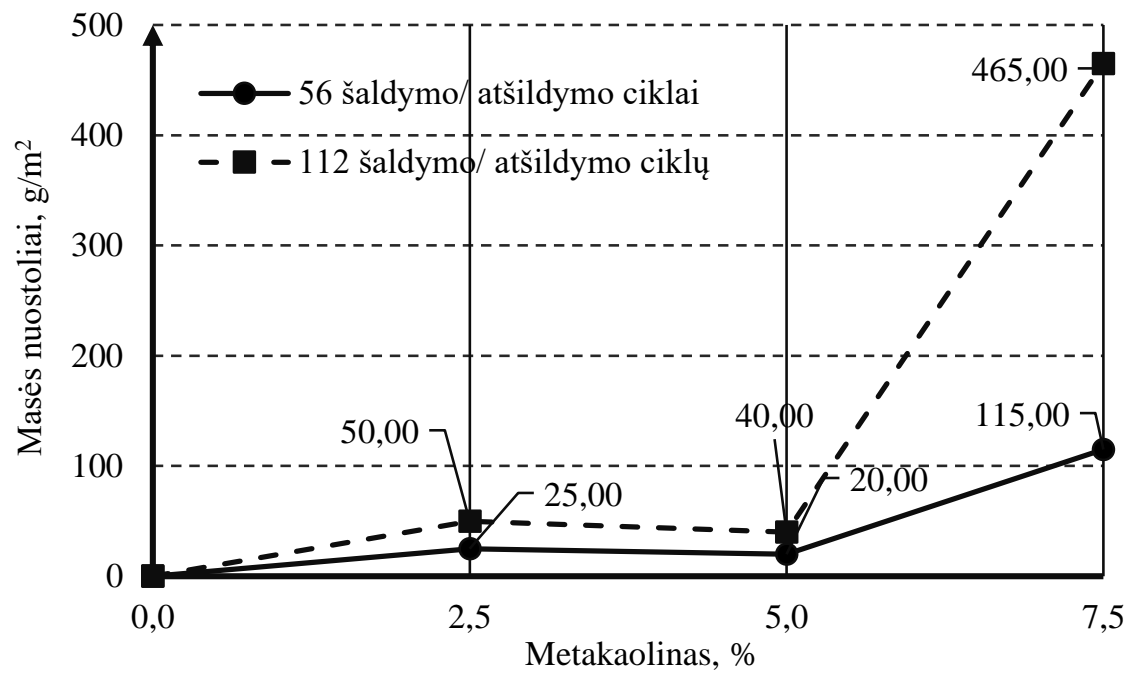

3.34 pav. Metakaolino poveikis smulkiagrūdžio stiklo plaušu armuoto betono paviršiniams masės nuostoliams, esant cikliškam šaldymui/atšildymui

Fig. 3.34. Impact of metakaolin on scaling at freezing/thawing of fine-grained glass fiber reinforced concrete 
Šiame tyrime SPAB betono bandinių didžiausi paviršiaus masès nuostoliai buvo 3 kartus mažesni negu siūlo standartas, kai užšaldymo ir atšildymo ciklų skaičius net 4 kartus viršijo reikalavimus. Nepaisant to, betono paviršių pažeidimai buvo labai ryškūs vizualine prasme. Bandiniuose su 7,5 \% metakaolino paviršiniai masès nuotoliai $465 \mathrm{~g} / \mathrm{m}^{2}$ sudare $39 \%$ bandinio paviršiaus ploto, o su $5 \%$ $\mathrm{SiO}_{2}$ mikrodulkių $45 \mathrm{~g} / \mathrm{m}^{2}$ atitinkamai $12 \%$ bandinio paviršiaus ploto (3.35 pav.).

Atskilusio paviršiaus ploto duomenys buvo gauti Autocad programos pagalba, konvertuojant nuotraukas pagal bandinio masteli ir apvedant defektus „Spline“ braižymo įrankiu bei komanda „Area“ apskaičiuojant kiekvieno objekto plotą $\mathrm{mm}^{2}$ (3.36 pav.). Būtų tikslinga nustatyti priklausomybę tarp masès nuostolių ir defektuoto paviršiaus ploto, tačiau tai padaryti sudètinga, kadangi priklausomai nuo cementinès matricos struktūros, defektų gylis gali skirtis. Šiuo atveju bandiniams su metakaolinu gauta $0,12 \mathrm{~g} / \mathrm{cm}^{2}$, o su $\mathrm{SiO}_{2}$ mikrodulkèmis $0,037 \mathrm{~g} / \mathrm{cm}^{2}$.

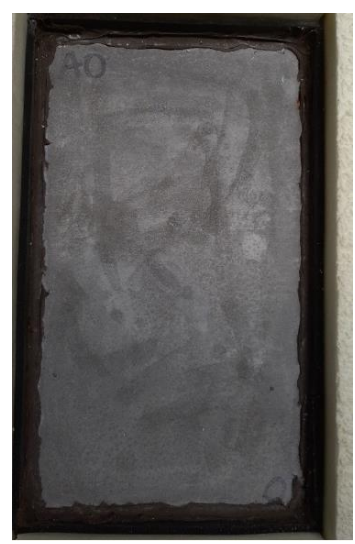

a)

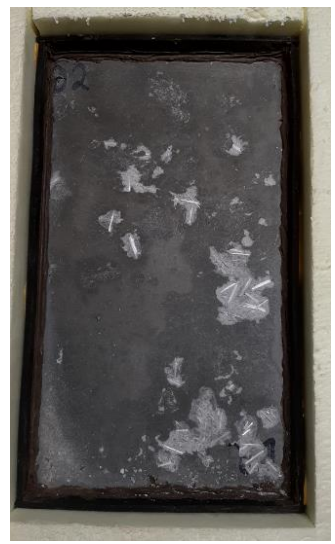

b)

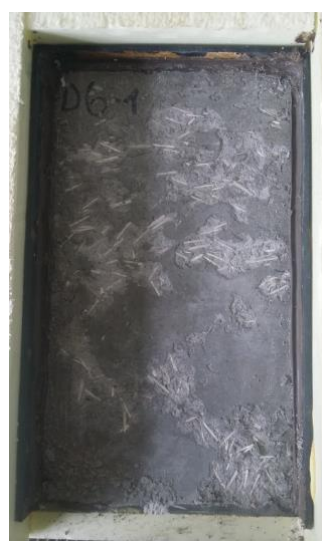

c)

3.35 pav. Bandinių paviršiai po 112 užšaldymo ir atšildymo ciklų su $3 \% \mathrm{NaCl}$ tirpalu:

a) S1, be mikroužpildų; b) MS1 su 2,5\% $\mathrm{SiO}_{2}$ mikrodulkių; c) MK3 su $7,5 \%$ metakaolino

Fig. 3.35. Photos of specimens after 112 freeze/thaw cycles: a) S1, with no additives; b) MS1 with 2,5\% silica fume; c) MK3 with 7,5\% metakaolin

Remiantis šiais rezultatais, reikètų pakeisti standarto LST EN 13198 siūlomus atsparumo šalčiui vertinimo kriterijus pagal masės nuostolius, keičiant ị priimtiną maksimalų defektų plotą gaminio paviršiuje $-\mathrm{cm}^{2} / \mathrm{m}^{2}$. Siūlomos maksimalios leistinos reikšmés galètų būti klasifikuojamos pagal tris skirtingas tolerancijos klases - A, B ir C (3.2 lentelè). 


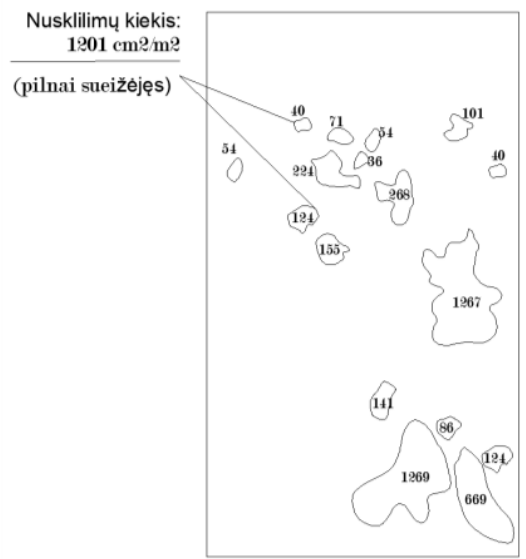

a)

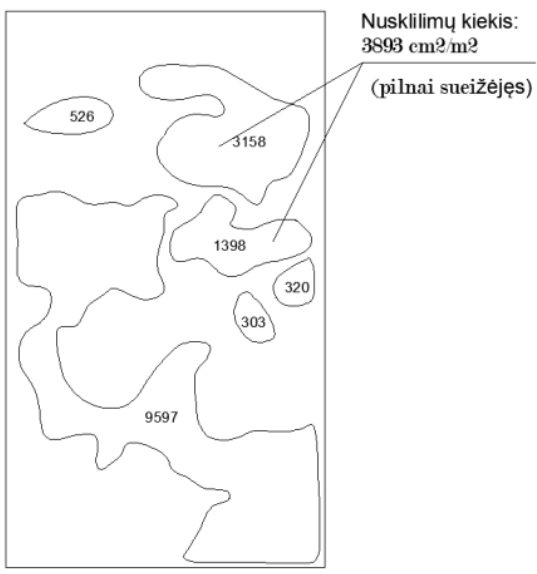

b)

3.36 pav. Paviršinių masès nuostolių scheminis atvaizdavimas ploto vienetais (matmenys $\mathrm{mm}^{2}$ ): a) MS1 su 2,5 \% $\mathrm{SiO}_{2}$ mikrodulkių; b) MK3 su 7,5 \% metakaolino

Fig. 3.36. Schematic representation of suface mass loss (dimmensions in $\mathrm{mm}^{2}$ ):

a) MS1 with 2,5\% silica fume; b) MK3 with 7,5\% metakaolin

3.2 lentelè. Apdailinio betono paviršiaus leistinų masès nuostolių vertès pagal skirtingas tolerancijos klases bandant pagal standarte LST EN 13198 pateiktą paviršinio užšaldymo ir atšildymo metodą po 112 ciklų druskos tirpale.

Table 3.2. Marginal values of surface mass loss according different tolerance classes, when freeze/thaw is tested by LST EN 13198 standart method.

\begin{tabular}{|c|c|c|c|c|}
\hline \multirow{2}{*}{$\begin{array}{c}\text { Kokybès } \\
\text { tolerancijos klase } \\
\text { (po } 112 \text { ciklų su } \\
3 \% \mathrm{NaCl})\end{array}$} & $\begin{array}{c}\text { Masès nu- } \\
\text { ostoliai, g/m }\end{array}$ & $\begin{array}{c}\text { Nuskilimų } \\
\text { bendras plo- } \\
\text { tas, } \mathrm{cm}^{2} / \mathrm{m}^{2}\end{array}$ & $\begin{array}{c}\text { Pagal plota, } \\
\mathrm{cm}^{2} / \mathrm{m}^{2}\end{array}$ & $\begin{array}{c}\text { nuskilimų } \\
\text { bendras plo- } \\
\text { tas, } \mathrm{cm}^{2} / \mathrm{m}^{2}\end{array}$ \\
\hline $\mathrm{A}$ & $\leq 2$ & $\leq 50$ & $\leq 6$ & $\leq 50$ \\
\hline $\mathrm{B}$ & $\leq 5$ & $\leq 150$ & $\leq 18$ & $\leq 150$ \\
\hline $\mathrm{C}$ & $\leq 18$ & $\leq 500$ & $\leq 60$ & $\leq 500$ \\
\hline
\end{tabular}

3.37 paveiksle pavaizduoti paviršinių nutrupejjimų (nuskilimų) kiekiai pagal 3.4 lenteleje pateiktas tolerancijos klases. 

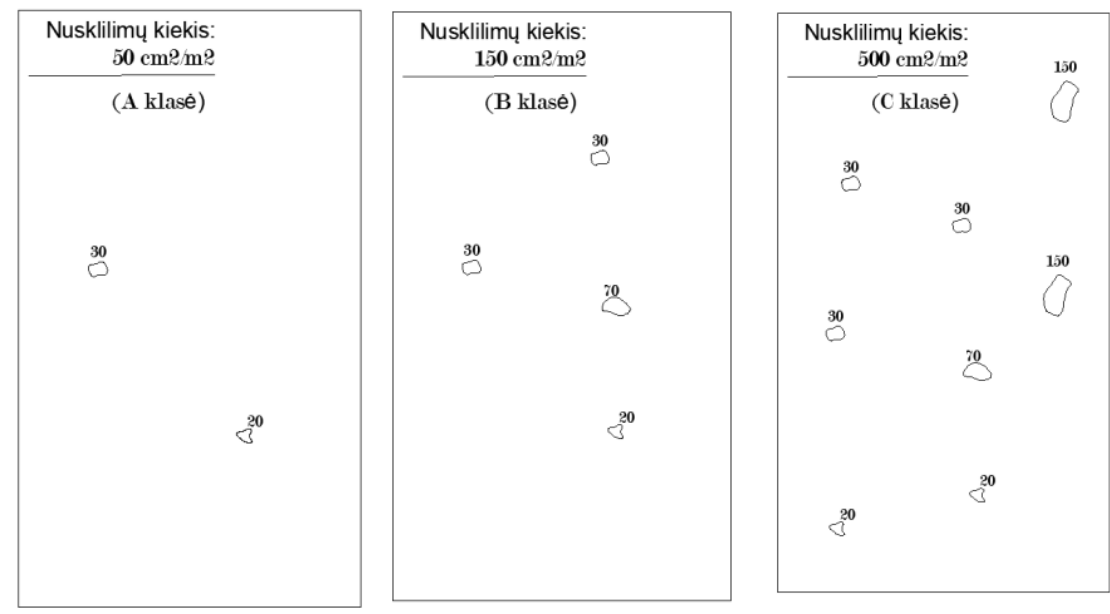

3.37 pav. Paviršinių masès nuostolių scheminis atvaizdavimas pagal kokybės klases:

a) $50 \mathrm{~cm}^{2} / \mathrm{m}^{2}$ (A klasè); b) $150 \mathrm{~cm}^{2} / \mathrm{m}^{2}$ (B klasè); c) $500 \mathrm{~cm}^{2} / \mathrm{m}^{2}$ (C klasè)

Fig. 3.37. Schematic representation of suface mass loss according tolerance classes:

a) $50 \mathrm{~cm}^{2} / \mathrm{m}^{2}$ (A class); b) $150 \mathrm{~cm}^{2} / \mathrm{m}^{2}$ (B class); c) $500 \mathrm{~cm}^{2} / \mathrm{m}^{2}$ (C class)

Aktyvūs mikro užpildai sukelia smulkigrūdžio stiklo plaušu armuoto betono paviršinius defektus, kaip betono paviršius yra veikiamas užšaldymo ir atšildymo ciklų. Didžiausias betono apdailinio paviršiaus atsparumas užšaldymo ir atšildymo ciklų poveikiui gautas su bazine sudètimi be mikroužpildų - po 112 ciklų defektų nepastebèta.

\subsubsection{Betono mechaninių savybių bei lenkimo deformaciju energijos pokyčių dẻl cikliško užšaldymo ir atšildymo tyrimai}

Užšaldymo ir atšildymo ciklų poveikis dažnai siejamas su ilgalaikiu betono stipruminių savybių blogèjimu - lenkimo bei gniuždymo stiprumo sumažejjimu. Tankioje cementineje matricoje augantys ledo kristalai neturi kur laisvai plèstis, susidaro dideli vidiniai ịtempimai ir betonas supleišèja, nuo paviršiaus palaipsniui atskyla cementinès plèvelès sluoksnis. Pastebèta, kad betone su stiklo plaušu, šio cementinès plèvès sluoksnio storis yra iki $2 \mathrm{~mm}$, po kuriuo išsidèstę pirmieji stiklo plaušo sluoksniai.

$\mathrm{Su}$ abiem mikroužpildais gautas mažesnis lenkimo stiprumas po 112 ciklų negu be jų. Su 2,5\% silicio mikrodulkių prieš šaldymą - 10,5 MPa, po šaldymo - 9,3 MPa. Su $5 \%$ prieš šaldymą - 9,0 MPa, po šaldymo - 8,0 MPa. Su 7,5 \% prieš šaldymą - 9,8 MPa, po šaldymo $-10,1 \mathrm{MPa}$ (3.38 pav.). 
Su 2,5 \% metakaolino prieš šaldymą - 10,2 MPa, po šaldymo - 8,8 MPa. Su $5 \%$ prieš šaldymą - 10,7 MPa, po šaldymo - 8,9 MPa. Su 7,5 \% prieš šaldymą 10,2 MPa, po šaldymo - 9,8 MPa (3.39 pav.).

Gauti duomenys rodo, kad bandiniuose su metakaolinu lenkimo stiprio poky-

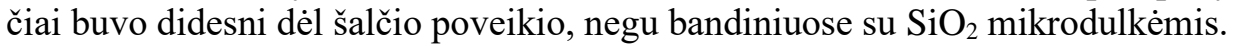

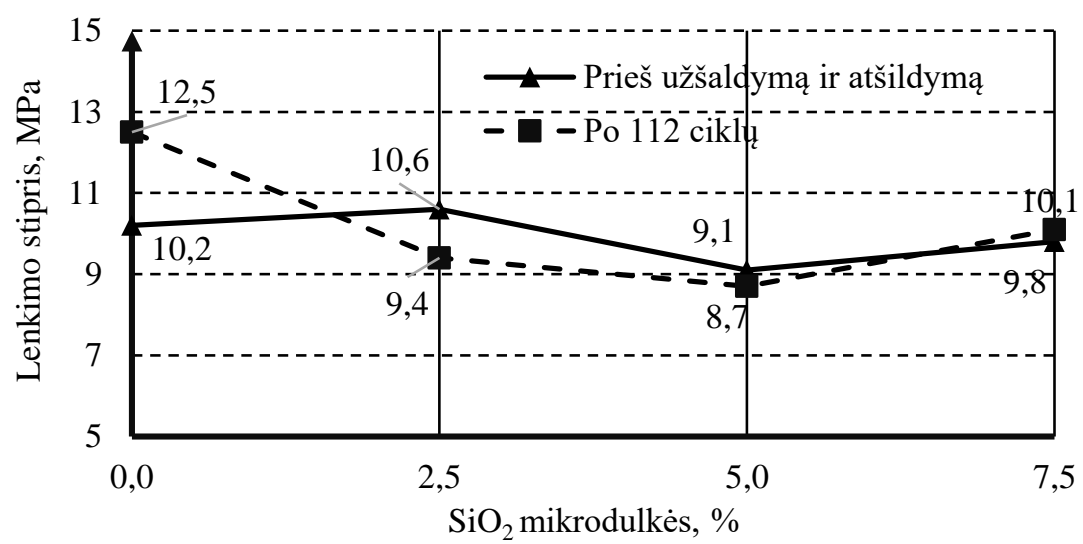

3.38 pav. $\mathrm{SiO}_{2}$ mikrodulkių poveikis smulkiagrūdžio stiklo plaušu armuoto betono lenkimo stipriui po 112 užšaldymo ir atšildymo ciklų

Fig. 3.38. Impact of silica fume on flexural strength of fine-grained glass fiber reinforced concrete after 112 freeze/thaw cycles

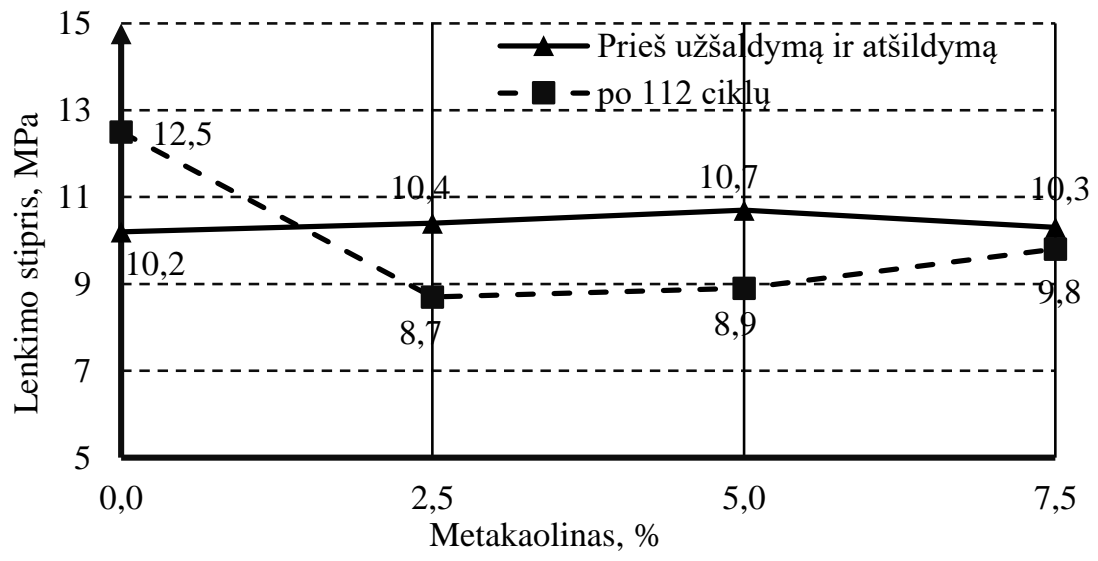

3.39 pav. Metakaolino poveikis smulkiagrūdžio stiklo plaušu armuoto betono lenkimo stipriui po 112 užšaldymo ir atšildymo ciklų

Fig. 3.39. Impact of metakaolin on flexural strength of fine-grained glass fiber reinforced concrete after 112 freeze/thaw cycles 
Atlikti lenkimo stiprio bandymai su skirtingu kiekiu $\mathrm{SiO}_{2}$ mikrodulkių bei metakaolino mineralinių priedų prieš užšaldymo ir atšildymo bandymą ir po 112 ciklų. Bandiniai buvo atremti lygia puse, kuri buvo šaldoma. Buvo nustatyta, kad kontrolinių bandinių (be mikroužpildų) lenkimo stiprumas padidejo $24 \%$ po 112 užšaldymo ir atšildymo ciklų, prieš šaldymą - 10,1 MPa, po šaldymo - 12,5 MPa. Tai gali būti siejama su tuo, kad bandiniai ilgą laiką buvo veikiami $\mathrm{NaCl}$ tirpalu, dèl ko susidare palankios sąlygos formuotis portlandito fazèms, kurios galèjo sutankinti matricą ir padidinti kompozito lenkimo stiprị.

Daryti išvadas apie aktyvių mineralinių priedų ịtaką stiklo plaušu armuoto ir užšaldymo ir atšildymo ciklų paveikto kompozito ilgalaikes mechanines charakteristikas sudètinga, kai nèra nagrinèjama visa lenkimo deformacijų kreivè. 3.40 ir 3.41 paveiksluose pateikti bandinių ịlinkiai prie $3 \mathrm{MPa}$ liekamojo stiprumo parodè, kad visų bandinių ịlinkiai sumažèjo 1,5-2 kartus po 112 užšaldymo ir atšildymo ciklų. Tai reiškia, kad stiklo plaušu armuotas kompozitas tapo trapesne medžiaga. Mineraliniai priedai padidino liekamajji ịlinkị iki 2 kartų, taip paveikdami kompozito ilgalaikes mechanines savybes.

Siekiant išsamiau ịvertinti stiklo plaušu armuoto betono mechaninių savybių pokyčius veikiant užšaldymo ir atšildymo ciklams, buvo apskaičiuotos bandinių lenkimo deformacijų energijos. Pagal tai galima palyginti kokią įtaką turi ịvairių betono sudéčių pokyčiai išorinių jègų atliekamam darbui nuo jègos pridejjimo iki pilno bandinio suardymo.

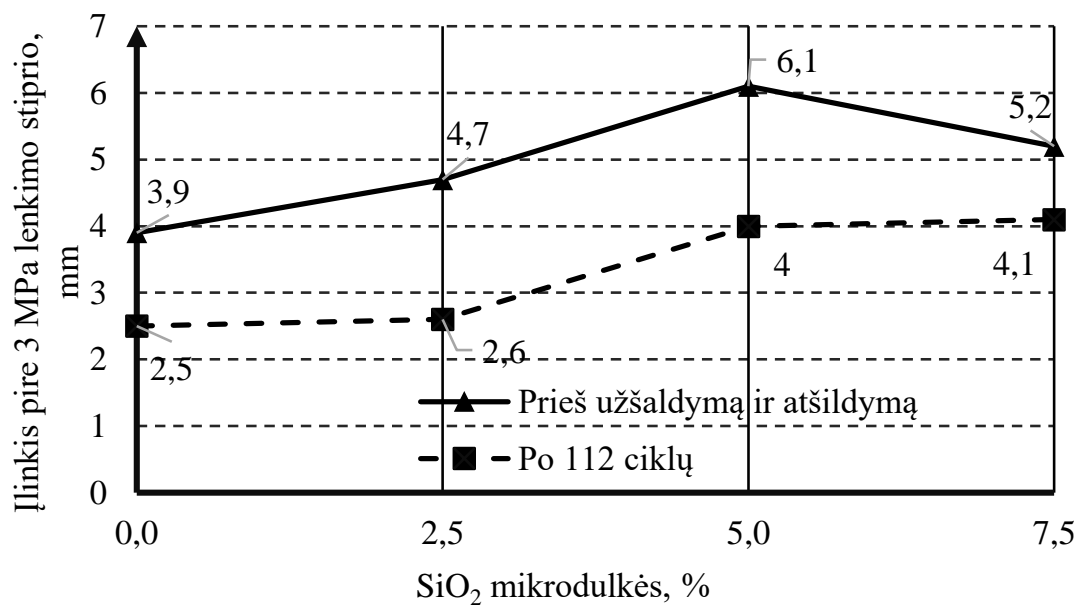

3.40 pav. $\mathrm{SiO}_{2}$ mikrodulkių poveikis smulkiagrūdžio stiklo plaušu armuoto betono maksimalioms deformacijoms (ilinkiui), kai liekamasis stipris - $3 \mathrm{MPa}$

Fig. 3.40. Impact of silica fume on maximum deformation of fine-grained glass fiber reinforced concrete when residual strength is $3 \mathrm{MPa}$ 


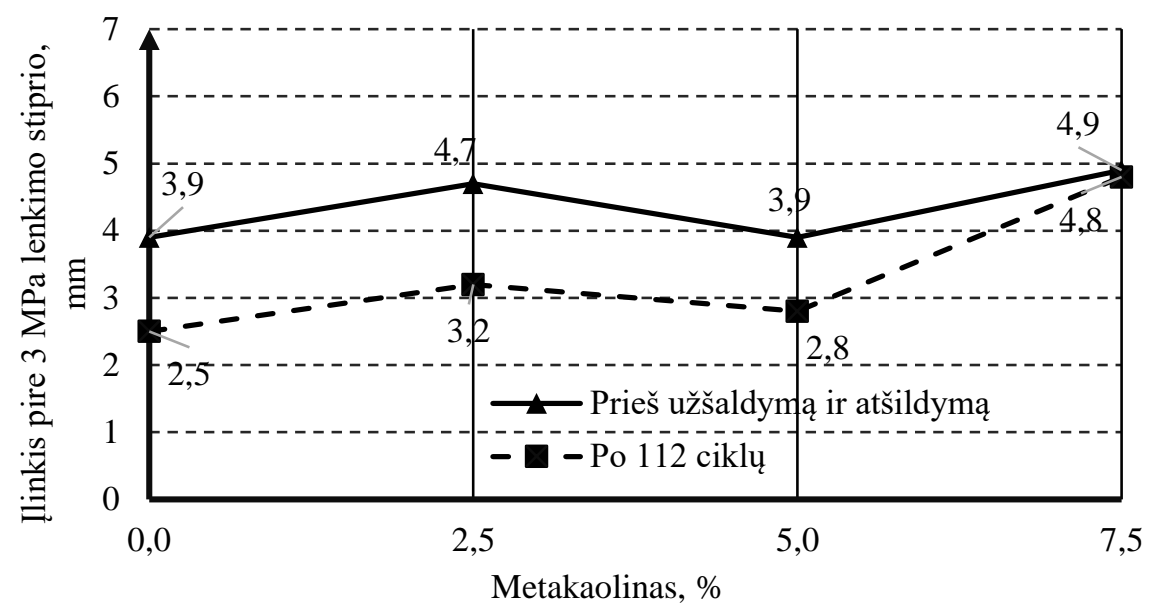

3.41 pav. Metakaolino poveikis smulkiagrūdžio stiklo plaušu armuoto betono maksimalioms deformacijoms (ilinkiui), kai liekamasis stipris $-3 \mathrm{MPa}$

Fig. 3.41. Impact of metakaolin on maximum deformation of fine-grained glass fiber reinforced concrete when residual strength is $3 \mathrm{MPa}$

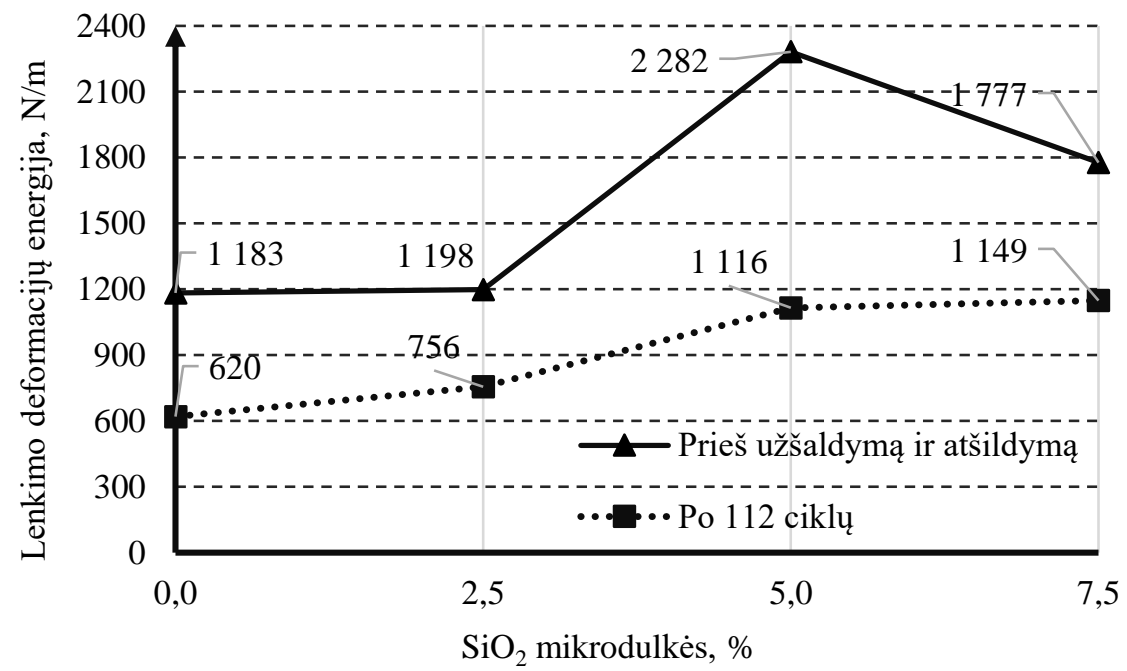

3.42 pav. $\mathrm{SiO}_{2}$ mikrodulkių poveikis smulkiagrūdžio stiklo plaušu armuoto betono lenkimo deformacijų energijai

Fig. 3.42. Impact of silica fume on flexural stain energy of fine-grained glass fiber reinforced concrete 


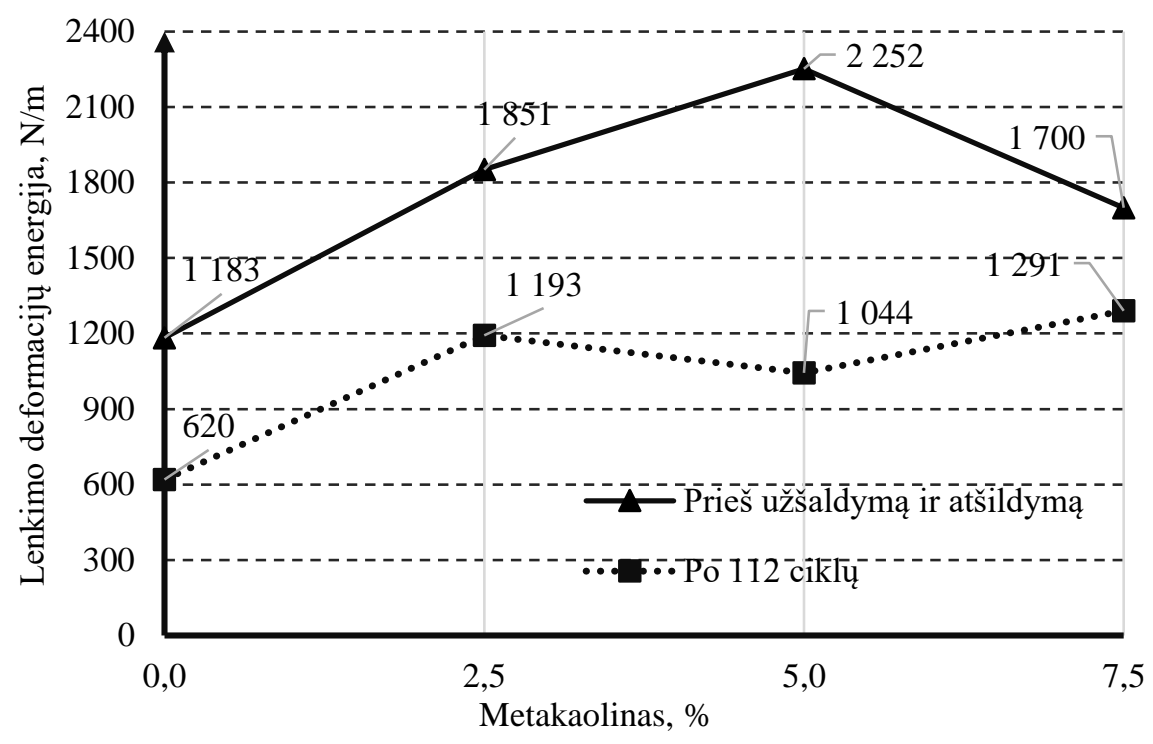

3.43 pav. Metakaolino poveikis smulkiagrūdžio stiklo plaušu armuoto betono lenkimo deformacijų energijai

Fig. 3.43. Impact of metakaolin on flexural stain energy of fine-grained glass fiber reinforced concrete

Nustatyta, kad silicio dioksido mikrodulkių priedas lenkimo deformacijų energiją padidino $92 \%$ neveikiant šalčiui ir $85 \%$ po 112 ciklų, o metakaolinas $90 \%$ neveikiant šalčiui ir $108 \%$ paveikus 112 užšaldymo ir atšildymo ciklų (3.42 pav. ir 3.43 pav.). Tai reiškia, kad padidejjo kompozito plastiškumas ir jo suardymui reikia daugiau energijos, medžiaga igavo didesnị atsparumą dinaminių jègų poveikiui (vèjo apkrovos, smūginès-impulsinès apkrovos), kas yra labai svarbu plonasienėms fasadų konstrukcijoms.

Skenuojančiu elektroniniu mikroskopu darytos nuotraukos parodè, kad SPAB betono be mikroužpildų (S1) plaušelių paviršius po šaldymo bandymų tapo šiurkštus (3.44 pav.), kas galèjo įtakoti lenkimo stiprio padidejjimą, kadangi šiurkštus paviršius geriau sukimba su cementine matrica. Paviršiaus šiurkštumą galèjo ịtakoti stiklo cheminè korozija šarminèje terpèje, kadangi cementinèje matricoje be aktyvių mikroužpildų yra didelis kiekis $\mathrm{OH}-$ jonų.

Plaušo - matricos kontakto zonoje kai kur buvo pastebimi plyšiai (3.45 pav.), dèl kurių galèjo sumažèti kompozito lenkimo deformacijų energija, o suirimo pobūdis pasidarè trapus. 


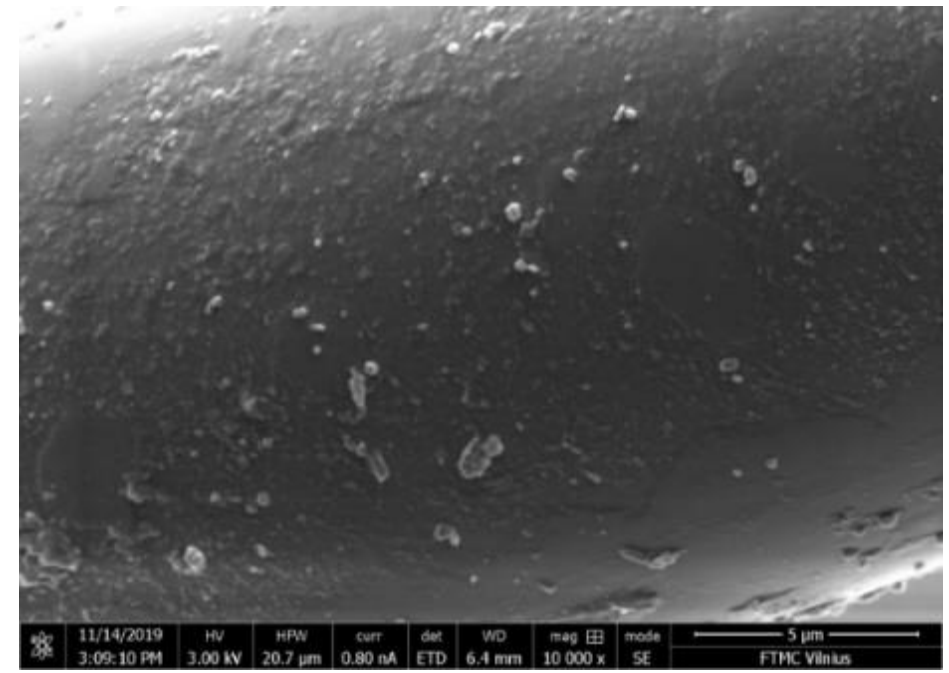

3.44 pav. S1 sudètis po 112 užšaldymo ir atšildymo ciklų: stiklo plaušo paviršius, didinimas $10000 \mathrm{x}$

Fig. 3.44. S1 composition after 112 freeze/thaw cycles: glass filament surface, magnification $10000 x$

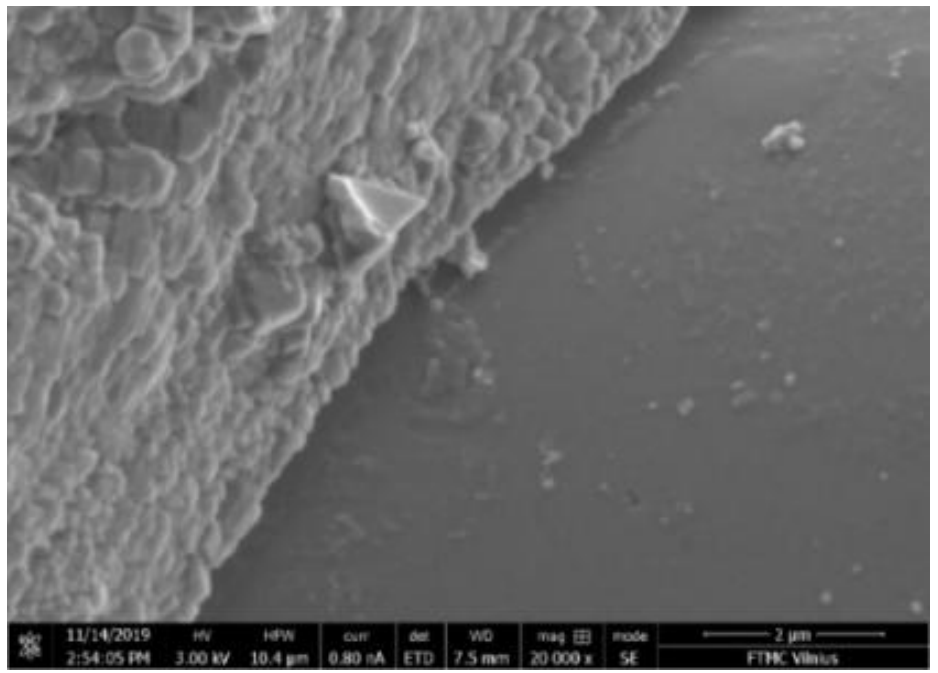

3.45 pav. S1 sudètis po 112 užšaldymo ir atšildymo ciklų: cementinès matricos struktūra bei plyšys tarp plaušo ir matricos, didinimas $20000 \mathrm{x}$

Fig. 3.45. S1 composition after 112 freeze/thaw cycles: crack between filament and matrix, magnification $20000 x$ 
Bandiniuose su mikroužpildais (MS3 ir MK3) stiklo plaušelių paviršius po šaldymo bandymų neturèjo paviršinių defektų, kurie buvo būdingi S1 bandiniams (3.44 pav. ir 3.47 pav.).

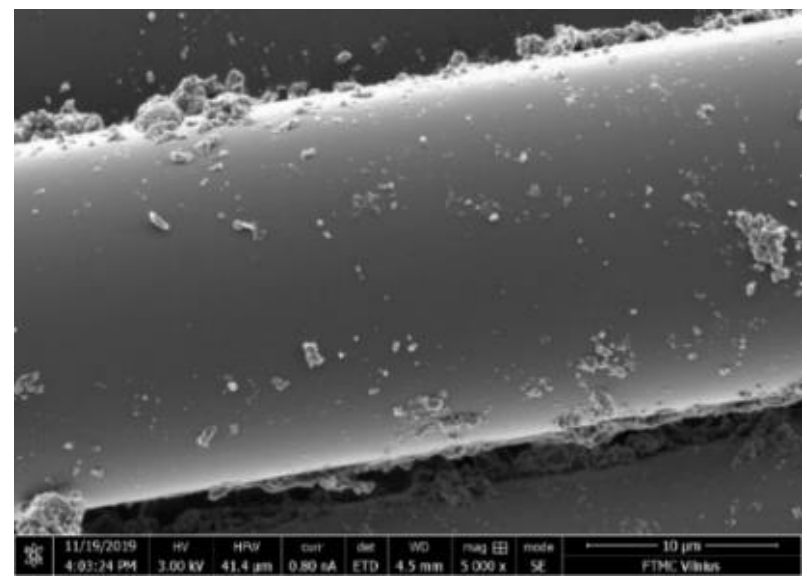

3.46 pav. MS3 sudètis po 112 užšaldymo ir atšildymo ciklų: stiklo plaušo paviršius, didinimas $5000 \mathrm{x}$.

Fig. 3.46. MS3 composition after 112 freeze/thaw cycles: glass filament surface, magnification $5000 x$

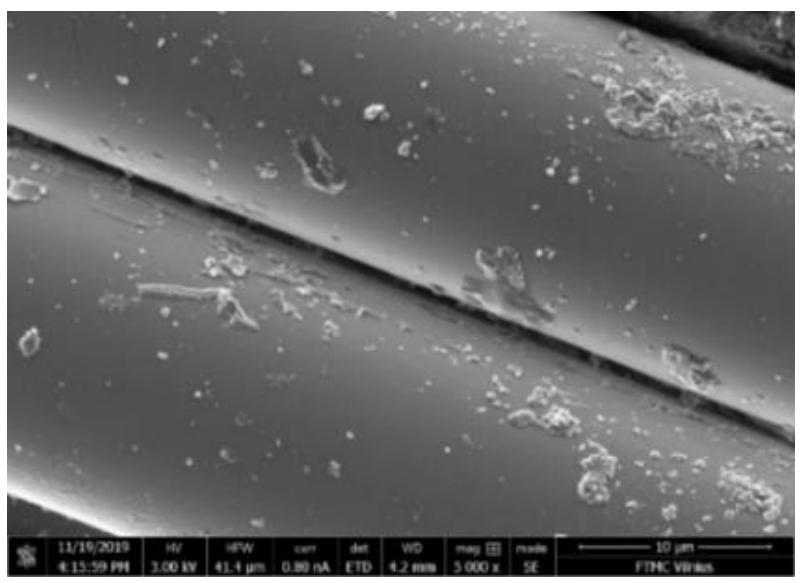

3.47 pav. MK3 sudètis po 112 užšaldymo ir atšildymo ciklų: stiklo plaušo paviršius, didinimas 5 000x.

Fig. 3.47. MK3 composition after 112 freeze/thaw cycles: glass filament surface, magnification $5000 x$ 
Remiantis šių eksperimentų rezultatais bei mokslininkų atliktais tyrimais, galima teigti, kad SPAB mechaninių savybių blogejjimo laipsnis, didejant kompozito eksploatavimo trukmei, pirmiausia priklauso nuo matricos porų tirpalo šarmingumo. Dėl vykstančios hidratacijos kontaktinèje zonoje, plaušelių paviršius vis dažniau būna padengtas hidratacijos produktais, kurių morfologija ir cheminè sudètis priklauso nuo rišiklio (Mills et al., 1981; Laws et al., 1986; Zhu et al., 1997).

Plonų CSH fazių sluoksnis, dẻl kurio susidaro geros rišimosi savybès, dominuoja tais atvejais, kai cemento klinkerio kiekis rišiklyje yra mažas ir (arba) naudojami pucolanines reakcijas sukeliantys priedai (mažas porų tirpalo šarmingumas). Cementinèse matricose kuriose rišikliu naudojamas tik portlandcementis vyrauja šiurkščios, trapios portlandito fazès (didelis porų tirpalo šarmingumas). Didèjant cementinès matricos šarmingumui didèja ir portlandito fazių kiekis, kurios suformuoja tam tikrus trapius apvalkalus stiklo plaušo paviršiuje. Taip pat gali būti pastebimas $\mathrm{Ca}(\mathrm{OH})_{2}$ kristalų ịsiterpimas tarp plaušelių aglomeratų. Augantys portlandito kristalai veikdami kaip pleištai sukraipo stiklo plaušelius ir pažeidžia išorinị sukibimą su matrica užtikrinantị apvalkalą (Huijun et al., 2013; Enfedaque et al., 2010; Madhkhan et al., 2019).

Cementinèse matricose, kuriose panaudojami aktyvūs mineraliniai priedai, dèl pucolaninių reakcijų sumažèja porų tirpalo $\mathrm{pH}$ vertès. Sąlygos portlandito susidarymui tokiu atveju yra apribojamos, todèl susidaro palanki plaušo ir matricos kontakto zonos mikrostruktūra. Susiformavusios naujos plonos plèvelès ant išorinių plaušelių paviršiaus užtikrina geresnį plaušo sukibimą su matrica. Mokslininų atlikti tyrimai su metakaolinino priedu veikiant stiklo plaušu armuotą betoną drèkinimo ir džiovinimo ciklais taip pat parodè, kad šis priedas sumažina kompozito trapumą dèl vykstančių senèjimo procesų, kaip ir šiame darbe atliktų užšaldymo ir atšildymo bandymų atveju (Purnell et al., 1999; Cheng et al., 2019; Bartos et al., 1996; Peled et al., 2005).

\subsection{Tyrimo rezultatụ praktinis taikymas}

Pagal gelžbetonio konstrukcijų gamybos pramonèje vyraujančias gamybos technologijas, trisluoksnių sieninių elementų apdailiniam (išoriniam) $80 \mathrm{~mm}$ storio sluoksniui dažniausiai naudojamas vienas B500B klasès armatūros tinklas, suformuojant $35 \mathrm{~mm}$ betono apsauginị sluoksnị. Šis armuotas $80 \mathrm{~mm}$ storio betono sluoksnis atlieka tik apdailinę fasado funkciją ir eksploatuojant pastatą papildomų apkrovu be savojo svorio neperima. Gamybos technologinio proceso metu, taip pat transportuojant ir montuojant gamini veikia ịvairios apkrovos ir poveikiai, kuriuos būtina ịvertinti. Šie poveikiai dažniausiai yra dinaminiai - smūginiai, todèl 
išorinio sluoksnio betonui reikalingas dažniausiai tik konstrukcinis armavimas užtikrinant gaminio standumą, stiprumą vientisumą keliant iš klojinio, padedant $\mathfrak{i}$ sandèliavimo vietą ar tvirtinant ant transportavimo piramidžių.

Dispersinis armavimas šiame darbe aprašytais plaušais iš esmès tenkina betonui keliamus reikalavimus prieš tai paminètų technologinių procesų metu, todèl gali būti panaudotas suploninant ịprastinị $80 \mathrm{~mm}$ betono apdailinị sluoksnị iki $15 \mathrm{~mm}$. Dèl gamyboje reikalaujamo didelio ankstyvojo stiprumo, rekomenduojama naudoti CEM I 52,5R klasès portlandcementị su polikarboksilatų esterio superplastikliu, dozuojant $1,1 \%$ nuo cemento masès. Siekiant užtikrinti geriausią mišinio konsistenciją, rekomenduojama naudoti kvarcinị smèlį, kurio kiekis lygus cemento kiekiui, t. y. $853 \mathrm{~kg} / \mathrm{m}^{3}$. Parinktas stiklo plaušo kiekis $-49,5 \mathrm{~kg} / \mathrm{m}^{3}$ užtikrina dideli lenkimo stiprị - 13,3 $\mathrm{MPa}$ ir suteikia trapiai medžiagai (betonui) plastinių savybių, kurias galima charakterizuoti lenkimo deformacijų energija $1183 \mathrm{~N} / \mathrm{m}$, kuri po 112 užšaldymo ir atšildymo ciklų $3 \% \mathrm{NaCl}$ tirpale sumažèja iki $620 \mathrm{~N} / \mathrm{m}$ ir dèl sudètingų senèjimo procesų stiklo plaušu armuotas betonas pereina ị trapią būseną. Siekiant užtikrinti šio kompozito atsparumą šalčiui, rekomenduojama naudoti $\mathrm{SiO}_{2}$ mikrodulkių priedą, dozuojant 5-7,5 \% nuo cemento masès.

\subsection{Trečiojo skyriaus išvados}

1. Dispersinis armavimas plaušais skirtingai veikia smulkiagrūdžio betono mišinio konsistenciją. Didžiausias mišinio pasklidimas gaunamas su stiklo ir PVA plaušais - $20 \mathrm{~cm}$, kai plaušų dozuojama atitinkamai 2,9 \% ir $1,5 \%$ nuo cementinès matricos masès. Net su mažiausiu anglies plaušo kiekiu $(0,18 \%)$ mišinys tampa standus. Bazalto plaušas taip daro didelị poveikị mišinio konsistencijai, nes dozuojant $1,4 \%$ plaušo gautas pasklidimas siekia vos $12 \mathrm{~cm}$.

2. Dispersinis armavimas plaušais pagerina smulkiagrūdžio betono kompozito mechanines savybes. Stiklo plaušas cementinès matricos deformacijų energiją padidina iki 38 kartų, o lenkimo stiprị 1,6-2 kartus, suteikdamas trapiai medžiagai plastiškumo savybių. Mechaninių savybių požiūriu geriausia alternatyva ịprastiniam stiklo plaušui yra polivinilo alkoholio plaušas (PVA), kuris lenkimo deformacijų energiją padidino 3 kartus, kai plaušų kiekis buvo vienodas. Anglies bei bazalto plaušai nežymiai padidino betono lenkimo stiprị ir deformacijų energiją.

3. Pasirinktos žaliavos (stiklo plaušas, kvarcinis smèlis ir $\mathrm{SiO}_{2}$ mikrodulkių priedas) padidino kompozito atsparumą trapiam suirimui ir pleišèjimui, todèl šią medžiagą galima panaudoti surenkamųjų sieninių elementų gamyboje, kaip apdailinị betono sluoksnị. 
4. Stiklo plaušu dispersiškai armuotam betonui būdingas mišinio sluoksniavimasis, kuomet stiklo plaušas atsiskiria nuo cementinès matricos. Sluoksniavimasis priklauso nuo užpildo dalelių formos ir, kintant užpildo dalelių pailgumo indeksui nuo 1,4 iki 1,64 , betono mišinio segregacijos rodiklis kinta nuo 1,9 iki 3,5.

5. Didžiausias mišinio pasklidimas gaunamas naudojant kvarcinio smèlio užpildą, kurio pailgumo rodiklis lygus 1,4. Tačiau iki $50 \%$ kvarcinio smèlio galima pakeisti granito atsijomis arba ịprastiniu žvyro karjerų smèliu vertinant betono mišinio technologines savybes pagal segregacijos rodiklį.

6. Granito atsijos ir ịprastinis smèlis neturi didelès įtakos stiklo plaušu armuoto betono lenkimo stipriui, kai šiais užpildais pakeičiama iki $50 \%$ kvarcinio smèlio.

7. Aktyvūs mikroužpildai veikia smulkiagrūdžio betono mišinio su stiklo plaušu konsistenciją. $\mathrm{SiO}_{2}$ mikrodulkès bei metakaolinas padidina mišinio pasklidimą, kai šių priedų dozuojama 2,5 \% nuo cemento masès, nekeičiant kitų mišinio komponentų kiekio. Toliau didinant šių mikroužpildų kiekius, mišinio konsistencija blogèja net jei išlaikomas vienodas vandens ir cemento santykis.

8. Aktyvūs mikroužpildai skirtingai veikia smulkiagrūdžio betono mišinio su stiklo plaušu poringumą (įtraukto oro kiekį). Mišinių be mikroužpildų itraukto oro kiekis svyruoja tarp 2-3\%. $\mathrm{SiO}_{2}$ mikrodulkès didina ịtraukto oro kieki, o metakaolinas jo beveik neitakoja, kai šių priedų kiekiai tarp 2,5-7,5\% nuo cemento kiekio.

9. $\mathrm{SiO}_{2}$ mikrodulkių priedas turėjo nežymų poveiki paviršiniams masės nuostoliams, kuris galètų būti paaiškinamas didesniu ịtraukto oro kiekiu betono mišinyje. Didžiausia užfiksuota reikšmè $-67 \mathrm{~g} / \mathrm{m}^{2}$, su $2,5 \% \mathrm{SiO}_{2}$ priedo. Metakaolino priedas turejjo didesnị poveikị betono paviršiaus pažeidimams. Kai šio priedo naudojama $2,5 \%$ ir $5 \%$, masès nuostoliai po 112 ciklų buvo panašūs kaip ir sudètyse $\mathrm{su} \mathrm{SiO}_{2}$ priedu ir neviršijo $50 \mathrm{~g} / \mathrm{m}^{2}$. Tačiau 7,5 \% metakaolino priedo padidino masès nuostolius nuo betono paviršiaus, atitinkamai iki $115 \mathrm{~g} / \mathrm{m}^{2}$ po 56 ciklų ir iki $465 \mathrm{~g} / \mathrm{m}^{2}$ po 112 ciklų. Tai gali būti paaiškinama dideliu matricos tankiu dèl padidinto smulkių dalelių kiekio ir sumažèjusio ịtraukto oro kiekio betono mišinyje $(2,5 \%)$.

10. Nustatyta, kad silicio dioksido mikrodulkių priedas lenkimo deformacijų energiją padidino iki $92 \%$ neveikiant šaldymu/atšildymu ir $85 \%$ po 112 ciklų, o metakaolinas - $90 \%$ neveikiant šaldymu/atšildymu ir $108 \%$ paveikus 112 užšaldymo ir atšildymo ciklų. Tai reiškia, kad padidèjo kompozito plastiškumas ir jo suardymui reikia daugiau energijos, 
medžiaga ịgavo didesnị atsparumą dinaminių jègų poveikiui (vèjo apkrovos, smūginès-impulsinès apkrovos), kas yra labai svarbu plonasienèms fasadų konstrukcijoms.

11. Tyrimai skenuojančiu elektroniniu mikroskopu parodè, kad stiklo pluoštas sudarytas iš pavienių plaušelių ir tempimo įtempius perima išoriniai plaušelių sluoksniai.

12. Po 112 užšaldymo ir atšildymo ciklų stiklo plaušelių paviršius kontakto zonoje su cemento matrica po šaldymo bandymų tapo šiurkštus. Tai gali būti paaiškinama stiklo chemine korozija šarminèje terpèje.

13. Plaušo ir matricos kontakto zonoje kai kur buvo pastebimi plyšiai, kurie galëjo atsirasti dèl augančiu portlandito kristalų, pažeidžiančių išorinị sukibimą su matrica užtikrinantị CSH fazių apvalkalą ir dèl ko galèjo sumažèti kompozito lenkimo deformacijų energija, o suirimo pobūdis pasidarè trapus.

14. Bandiniuose su $\mathrm{SiO}_{2}$ mikrodulkių ir metakaolino priedais stiklo plaušelių paviršius po cikliško užšaldymo ir atšildymo bandymų nepastebèta paviršinių defektų, kurie buvo būdingi bandiniams be šių priedų. Dėl pucolaninių reakcijų susiformavusios naujos plonos CSH fazių plèvelès ant išorinių plaušelių paviršiaus užtikrina geresnį plaušo sukibimą su matrica. 


\section{Bendrosios išvados}

1. Smulkiagrūdžio stiklo plaušu armuoto betono mišinio konsistencija ir segregacija priklauso nuo užpildo dalelių formos, kurią galima apibūdinti pailgumo indeksu, kuris išreiškiamas kaip dalelès ilgesnès kraštinès santykis su trumpesniaja. Didejjant pailgumo indeksui, konsistencija blogèja ir segregacija didèja. Užpildo dalelių pailgumo indeksui padidejus $3 \%$ mišinio pasklidimas sumažèja $10 \%$, kai vietoje kvarcinio smèlio naudojamas ịprastinis smèlis. Kai naudojamas netaisyklingos formos užpildas (granito atsijos), dalelių pailgumo indeksas lyginant su kvarciniu smèliu padideja $33 \%$, o mišinio pasklidimas atitinkamai sumažèja iki $50 \%$. Didinant ịprastinio smèlio kieki nuo $10 \%$ iki $50 \%$, segregacijos rodiklis didèja nuo 1,9 iki 2,6, o naudojant granito atsijas atitinkamai nuo 2,6 iki 3,5.

2. Stiklo plaušu armuotam smulkiagrūdžiam betonui užtikrinamas tolygus cementinès matricos ir plaušo sklidimas, kai naudojami užpildai, kuriuose vyrauja sferinès formos dalelès, kurių pailgumo indeksas neviršija 1,4. Taip pat šiems mišiniams svarbus segregacijos rodiklis, kurị reikia vertinti technologinių operacijų metu ir galima apskaičiuoti pagal šiame darbe sukurtą metodiką. 
3. Ruošiant betono mišinius intensyvaus maišymo būdu, anglies ir bazalto plaušų aglomeratai suyra ị pavienius plaušelius ir mišinys tampa standus bei netechnologiškas. Šiuo požiūriu yra tinkamesnis stiklo plaušas, kurio plaušeliai net intensyvaus maišymo metu lieka sukibę i aglomeratus ir išlieka tiesios formos, taip užtikrindami reikiamą mišinio pasklidimą ir pakankamą cementinès matricos armavimą.

4. Naudojant dispersinį armavimą plaušais, galima pagerinti betono kompozito mechanines charakteristikas. Nustatyta, kad stiklo plaušas betono kompozito lenkimo deformacijų energiją padidina nuo $28 \mathrm{~N} / \mathrm{m}$ iki $1039 \mathrm{~N} / \mathrm{m}$ (38 kartus), o polivinilo alkoholio plaušas nuo $28 \mathrm{~N} / \mathrm{m}$ iki $3102 \mathrm{~N} / \mathrm{m}$ (114 kartų), taip suteikdamas trapiai medžiagai plastiškumo savybių, kai stiklo plaušo dozuojama 2,9 \%, o polivinilo alkoholio $1,5 \%$ nuo sausų medžiagų masès.

5. $\mathrm{SiO}_{2}$ mikrodulkių bei metakaolino priedai gali sukelti cementinio akmens atskilinejjimus nuo betono apdailinio paviršiaus, veikiant užšaldymo ir atšildymo ciklams, kai šių priedų dozuojama iki 7,5 \% nuo cemento masès. Todèl vertinant gaminių išvaizdą pasiūlyta taikyti skirtingas kokybès klases (A, B, C) ribojant atskilusio betono paviršiaus plotą nuo $50 \mathrm{~cm}^{2} / \mathrm{m}^{2}$ iki $500 \mathrm{~cm}^{2} / \mathrm{m}^{2}$.

6. Po 112 šaldymo ir atšildymo ciklų $3 \% \mathrm{NaCl}$ tirpale $\mathrm{SiO}_{2}$ mikrodulkių priedas stiklo plaušu dispersiškai armuoto betono kompozito lenkimo deformacijų energiją padidina nuo $620 \mathrm{~N} / \mathrm{m}$ iki $1149 \mathrm{~N} / \mathrm{m}(85 \%)$, o metakaolinas - nuo 620 N/m iki 1149 N/m (108\%). Tokiu būdu šie priedai dèl didesnių plastinių deformacijų ir liekamojo stiprio padeda nagrinèjamiems kompozitams išlikti atspariems suardymui, veikiant agresyvioms klimato sąlygoms eksploatacijos metu.

7. Vykstant senèjimo procesams dẻl užšaldymo ir atšildymo ciklų poveikio stiklo plaušu armuotas kompozitas pereina ị trapią būseną galimai dèl atsirandančių plyšių tarp plaušo ir matricos kontakto zonos, bei defektų plaušo paviršiuje. Šiuos senejjimo procesus gali sulètinti aktyvių mineralinių priedų ( $\mathrm{SiO}_{2}$ mikrodulkių ir metakolino) panaudojimas.

8. Sukurtas betono kompozitas surenkamujų sieninių elementų gamybai su kvarcinio smėlio užpildu ir stiklo plaušu, kurio lenkimo stipris $10,1 \mathrm{MPa}$, lenkimo deformacijų energija $-1149 \mathrm{~N} / \mathrm{m}$ ir kuris gali būti panaudotas fasadų konstrukcijoms, eksploatuojamoms ne mažiau kaip 20 metu agresyviomis Baltijos regiono klimato sąlygomis, kurioms būdingas užšaldymo ir atšildymo ciklų poveikis. 


\section{Literatūra ir šaltiniai}

Abe J.; Takeuchi Y.; Ogata Y.; Imai K. 2011. Development of Self-compacting Premix GRC, GRCA symposium, Istanbul.

Afroughsabet V.; Biolzia L.; Monteiro P. J. M. 2017. The effect of steel and polypropylene fibers on the chloride diffusivity and drying shrinkage of high-strength concrete. Composites Part B: Engineering 139: 84-96.

Afroz M.; Patnaikuni I.; Venkatesan S. 2017. Chemical durability and performance of modified basalt fiber in concrete medium. Constr. Build. Mater. 154: 191-203.

Aghabaglou A. M.; Sezer G. I.; Ramyar K. 2014. Comparison of fly ash, silica fume and metakaolin from mechanical properties and durability performance of mortar mixtures view point. Construction and Building Materials 70: 17-25.

Ahmad S.; Umarb A. 2018. Rheological and mechanical properties of self-compacting concrete with glass and polyvinyl alcohol fibers. Journal of Building Engineering 17: 6574.

Akers S. A. S. 2009. Cracking in fiber cement products. AC Consulting, Vorderdorfstrasse 31, 8753 Mollis, Switzerland.

Arisoy B.; Wu H. C. 2008. Material characteristics of high-performance lightweight concrete reinforced with PVA. Construction and building materials 22: 635-645.

Aulia T. B. 2002. Effects of Polypropylene Fibers on the Properties of High-Strength Concretes. LACER 7: 43-59. 
Baklanova N. I.; Utkin A. V. 2013. Alkali resistance, improved alkali resistance of basalt fibers with zirconia and titania coatings. Cem. Concr. Res. 53: 1-8.

Ball H. 1993. Durability of naturally aged, GFRC mixes conaining Forton Polymer and SEM analysis of the facture interface. Reco mmended Practice for Glass Fiber Reinforced Concrete Panels, Fourth Edition, MNL-128-01. PCI, Chicago, IL.

Bartos P. J. M. 2017. Glassfiber reinforced concrete: principles, prodution, properties and applications. Whittles Publishing. 183p.

Bartos M. J.; Zhu W. 1996. Effect of microsilica and acrylic polymer treatment on the ageing of GRC. Cement and Concrete Composites 18: 31-39.

Bai J., Wild S., Ware J.A., Sabir B.B. 2003. Using neural networks to predict workability of concrete incorporating metakaolin and fly ash, Advanced Engineering Software 34: 663-669.

Bentur A. 1985. Proceedings in PCI symposium: Durability of Glass Fiber Reinforced Concrete, Illinois, USA, 108.

Bijen J.; Jacobs M. 1982. Properties of glass fiber-reinforced polymer-modified cement. Matériaux et Construction 15: 445-452.

Biryukovich K. L.; Biryukovich Yu. L.; 1964. Steklocement, Budivelnik, Kiev.

Biswas R. K.; Iwanami M.; Chijiwa N.; Uno K. 2020. Effect of non-uniform rebar corrosion on structural performance of RC structures: A numerical and experimental investigation. Construction and Building Materials, 230.

Blott S. J.; Pye K. 2007. Particle shape: a review and new methods of characterization and class fication. Sedimentology 55: 31-63.

Bradley A. 2016. Processing, structure, and properties of carbon fibers. Composites Part A: Applied Science and Manufacturing 91: 262-282.

Brandt A. M.; Glinicki M. A. 2003. Effects of pozzolanic additives on long-term flexural toughness of HPGRC. Fourth international workshop on high performance fiber reinforced cement composites, University of Michigan and the University of Stuttgard.

Branston J.; Das S.; Kenno S. Y.; Taylor C. 2016. Mechanical behaviour of basalt fiber reinforced concrete. Constr. Build. Mat. 124: 878-886.

Branston J.; Das S.; Kenno S. Y.; Taylor C. 2016. Influence of basalt fibers on free and restrained plastic shrinkage. Cem. Concr. Comp. 74: 182-190.

Brooks J. J., Megat Johari M. A. 2001. Effect of metakaolin on creep and shrinkage of concrete, Cement Concrete Composites 23(6): 495-502.

Butler M.; Mechtcherine V.; Hempel S. 2009. Experimental investigations on the durability of fiber -matrix interfaces in textile-reinforced concrete. Cement and Concrete Composites 31: 221-231.

Building Research Establishment Information Paper CP38/79, Properties of GRC: ten year results, 1979. 
Cho G. C.; Dodds J.; Santamarina J.C. 2006. Particle shape effects on packing density, stiffness, and strength: natural and crushed sands. J Geotech Geoenviron Eng 132(5): 591602.

Cheng C.; He J.; Zhang J.; Yang Y. 2019. Study on the time-dependent mechanical properties of glass fiber reinforced cement (GRC) with fly ash or slag, Construction and Building Materials 217: 128-136.

Cohen M. D.; Constantiner D. 1985. Proceedings in PCI symposium: Durability of Glass Fiber Reinforced Concrete, Illinois, USA, 158

Cordeiro C. G., Soares L. M., Rocha C. A. A. 2016. Rheological and mechanical properties of concrete containing crushed granite fine aggregate, Construction and Building Materials 111: 766-773.

Correia R.; Ferreira J.; Branco A. 2006. A rehabilitation study of sandwich GRC façade panels. Construction and Building Materials 20: 554-561

Courard L., Darimont A., Schouterden M., Ferauche F., Willem X., Degeimbre R. 2003 Durability of mortar modified with metakaolin, Cement Concrete Research 33(9): 14731479.

Dhand V.; Mittal G., Rhee K. Y.; Park S.; Hui D. 2015. A short review on basalt fiber reinforced polymer composites. Composites Part B 73: 166-180.

Diamond S. 1985. Proceedings in PCI symposium: Durability of Glass Fiber Reinforced Concrete, Illinois, USA, 199.

Echevarria M. J.; Alonso M. J.; Romero D.C.; Montero, R. 2018. Influence of the previous state of corrosion of rebars in predicting the service life of reinforced concrete structures. Construction and Building Materials 188: 915-923.

Emamian S. A, Eskandari-Naddaf H. 2020. Genetic progra mming based formulation for compressive and flexural strength of cement mortar containing nano and micro silica after freeze and thaw cycles, Construction and Building Materials 241: 118027.

Enfedaque A.; Cendón D.; Gálvez F.; Sánchez-Gálvez V. 2010. Analysis of glass fiber reinforced cement (GRC) fracture surfaces, Construction and Building Materials 24: 1302-1308.

Enfedaque A.; Paradela L.S.; Galvez V.S. 2012. An alternative methodology to predict aging effects on the mechanical properties of glass fiber reinforced cements (GRC).

EN 15191:2009. Precast concrete products. Classification of glassfiber reinforced concrete performance

EN 13198:2003. Precast concrete products. Street furniture and garden products

Fenu L., Forni D., Cadoni E. 2016. Dynamic behavior of cement mortars reinforced with glass and basalt fibers, Composites Part B 92: 142-150.

Fiore V.; Scalici T.; Bella G.; Valenza A. 2015, A review on basalt fiber and its composites. Composites: Part B 74: 74-94. 
Flores Y. C., Cordeiro G. C., Filho R.D.T., Tavares L. M. 2017. Performance of Portland cement pastes containing nano-silica and different types of silica, Construction Building Materials 146: 526-530.

Frank E.; Steudle L. M.; Ingildeev D.; Sporl J. M.; Buchmeiser M. R. 2014. Carbon fibers: precursor systems, processing, structure, and properties. Angewandte Chemie International Edition 53: 5262-5298.

Förster T.; Hao B.; Mäder E.; Simon F.; Wölfel E. 2016. CVD-Grown CNTs on Basalt Fiber Surfaces for Multifunctional Composite Interphases. Fibers 4.4: 28.

Frederick T.; Paul A. 2009. Fiberglass and Glass Technology: Energy-Friendly Compositions and Applications. Springer: 211.

Gao, S.L.; Mader, E.; Plonka, R. 2007. Nanocomposite coatings for healing surface defects of glass fibers and improving interfacial adhesion. Composites Science and Technology 68: 2892-2901.

Gopalaratnam V.S. 1995. On the Characterization of Flexural Toughness in Fiber Reinforced Concretes. Cement \& Concrete Composites 17: 239-254.

Gribniak V.; Kaklauskas G.; Torresc L.; Daniunas A.; Timinskas E.; Gudonis E. 2013. Co MParative analysis of deformations and tension-stiffening in concrete beams reinforced with GFRP or steel bars and fibers. Composites Part B: Engineering 50: 158-170.

Grimer F.J.; Ali M.A. 1969. The strength of cements reinforced with galss fibers. Magasine of concrete research 21-16: 23-30.

Gruszczyński M., Lenart M. 2020. Durability of mortars modified with the addition of amorphous aluminum silicate and silica fume, Theoretical and Applied Fracture Mechanics 107: 102526.

Guan X.; Liu X.; Jis X.; Yuan Y.; Cui J.; Mang H. A. 2015. A stochastic multiscale model for predicting mechanical properties of fiber reinforced concrete. International Journal of Solids and Structures 56: 280-289.

Hillerborg A.; Modéer M.; Petersson P. E. 1976. Analysis of crack formation and crack growth in concrete by means of fracture mechanics and finite elements, Cement and Concrete Research 6: 773-782.

Hillerborg A. 1985. The theoretical basis of a method to determine the fracture energy GF of concrete. Mater. Struct. 18: 291-296.

Huijun W.; Jing Z.; Zhomgehang W.; Ting, S.; 2013. Damage action of Alkali-resistant Glass Fiber in Cement-based Material. Journal of Wuhan University of Technology-Mater Sci. Ed.:761-765.

Ispir M.; Dalgic K. D.; Hajihosseinlou S.; Ilki A. 2015. Long term deformation monitoring of GRC façade panels under ambient conditions. GRCA congress 2015 proceedings

Jamshidia M.; Ramezanianpourb A. A. 2011. Laboratory and industrial investigations on hybrid of acrylic and glass short fibers as an alternative for substituting asbestos in Hatschek process. Construction and Building Materials 25-1: 298-302. 
Jaras A. C.; Litherland, K. L. 1975. Proceedings in RILEM symposium: Fiber Reinforced Cement and Concrete, 327.

Jiang C.; Fan K.; Wu F.; Chen D. 2014. Experimental study on the mechanical properties and microstructure of chopped basalt fiber reinforced concrete. Mat. Design 58: 187-193.

Khandel S.; Rhee K. Y. 2020. Recent advances in basalt-fiber-reinforced composites: Tailoring the fiber-matrix interface. Composites Part B: Engineering 192: 108011.

Khana M. I., Siddiqueb R. 2011. Utilization of silica fume in concrete: Review of durability properties.

Köksal F., Altun F., Yigit I., Sahin Y. 2008. Combined effect of silica fume and steel fiber on the mechanical properties of high strength concretes, Construction Building Materials 22 (8): 1874-1880.

Krumbein W. C. 1941. Measurement and geological significance of shape and roundness of sedimentary particles. J Sediment Res 11: 64-72.

Krumbein W. C.; Sloss L. L. 1963. Stratigraphy and sedimentation. 2nd ed. San Francisco: W.H. Freeman and Company.

Laws V.; Langley A.A.; West J.M. 1986. The glass fiber/cement bond. Journal of Materials science 21: 289-296

Lee, J. J.; Song J.; Kim H. 2014. Chemical stability of basalt fiber in alkaline solution. Fibers Polym.15: 2329-2334.

Lees G. 1964. A new method for determining the angularity of particles. Sedimentology 3: $2-21$.

Li Z., Ding Z. 2003. Property improvement of Portland cement by incorporating with metakaolin and slag, Cement Concrete Research 33: 579-584.

Litherland K. L.; Oakley D. R.; Proctor B. A. 1981. The use of accelerated ageing procedures to predict the long term strength of GRC composites. Cement and Concrete Research 11: 455-466.

Loewenstein K. L. 1973. The Manufacturing Technology of Continuous Glass Fibers. New York Elsevier Scientific: 2-94.

Lu J.; Li W.; Kang H.; Feng L.; Xu J.; Liu R. 2020. Microstructure and properties of polyacrylonitrile based carbon fibers. Polymer Testing 81: 106267.

Mader, E.; Plonka, R. 2004. Coatings on alkali-resistant glass fibers for the improvement of concrete. Journal of Industrial Textiles 33: 191-208.

Madhkhan M., Katirai R. 2019 Effect of pozzolanic materials on mechanical properties and aging of glass fiber reinforced concrete, Construction and Building Materials 225: $146-158$.

Magalhães M. S.; Toledo Filho R. D.; Fairbairn E. M. R. 2013. Durability under thermal loads of polyvinyl alcohol fibers. Matéria (Rio J.) 18: 1587-1595. 
Majumdar A. J.; West J. M.; Larner, L. J. 1977. Properties of glass fibers in cement environment. Journal of Materials Science 12: 927-936.

Mehta P. K., Monteiro P. J. 2006. Concrete: Microstructure, Properties, and Materials, McGraw-Hill, New York.

Mills R. H. 1981. Preferential precipitation of calcium hydroxide on alkali-resistant glass fibers. Cement and Concrete Research 11: 689-697.

Mills R. H. 1981. Age-embrittlement of glass-reinforced concrete containing blast furnace slag, Cem. Concr. Res. 11: 421-428.

Moussard, M.; Garibaldi, P.; Curbach, M. 2017. The Invention of Reinforced Concrete (1848-1906), High Tech Concrete: Where Technology and Engineering Meet, 27852794.

Myadaraboina H., Atmaja E.S. 2015. Stability of basalt fibers in concrete medium. 2nd R.N. Raikar Memorial International Conference. 19 December, Mumbai, India.

National Precast Concrete Association of Australia. 2006. Design, Manufacture and Installation of Glass Reinforced Concrete (GRC), Suite 2, 13 Brighton Road, Glenelg, SA 5045, Australia.

Ngab P. L.; Barrosc J. A. O.; Kaklauskas G.; Lame J. Y. K. 2020. Deformation analysis of fiber-reinforced polymer reinforced concrete beams by tension-stiffening approach. Composite Structures 234.

Nicolas R., Cyr M., Escadeillas G. 2014. Performance-based approach to durability of concrete containing flash-calcined metakaolin as cement replacement. Construction and Building Materials 55: 313-322.

Orlowsky, J.; Raupach, M.; Cuypers, H.; Wastiels, J. 2005. Durability modeling of glass fiber reinforcement in cementitious environment. Materials and Structures 38: 155-162

Paeglea I.; Minellib F.; Fischera G. 2016. Cracking and load-deformation behavior of fiber reinforced concrete: Influence of testing method. Cement and Concrete Composites 73: $147-163$.

Palmer, R. 2011. The Masdar Institute's GRC Residential Facade. GRCA international conference, Istambul.

Patterson W. A., Chan H. C. 1975. Fracture toughness of glass fibre-reinforced cement, Composites 6: 102-104.

Paul, A. 1977. Chemical durability of glasses: a thermodynamic approach. Journal of Materials Science 12: 2246-2268.

Peled A.; Jones J.; Shah S.P. 2005. Effect of matrix modification on durability of glass fiber reinforced cement composites. Materials and Structures 38: 163-171.

Peter I. D.; Crocker I. 2015 Further Investigations into Premix GRC, GRCA symposium, Dubai.

Pigeon M., Pleau R. 2010. Durability of Concrete in Cold Climates, CRC Press, 2010. 
Powers M. C. 1953 A new roundness scale for sedimentary particles. SEPM J Sediment Res. 23:117-9.

Poon C.S., Lam I., Kou S.C., Wong Y.L., Wong R. 2001. Rate of pozzolanic reaction of metakaolin in high-performance cement pastes, Cement Concrete Research 31: 13011306.

Purnell P.; Beddows J. 2005. Durability and simulated ageing of new matrix glass fiber reinforced concrete. Cement and Concrete Composites 27: 875-884.

Purnell P.; Cain J.; Itterbeck P.; Lesko J. 2008. Service life modeling of fiber composites: A unified approach. Composites Science and technology 68: 3330-3336.

Purnell P., Short N. R.; Page C. L.; Majumdar A. J. 1999. Accelerated ageing characteristics of glass-fiber reinforced cement made with new cementitious matrices. Composites: Part A 30: 1073-1080.

Purnell P.; Short N.R.; Page C.L. 2001. Super-critical carbonation of glass-fiber reinforced cement. Composites Part A: Applied science and manufacturing 32: 1777-1787

Purnell P., Short N. R.; Page C. L.; Majumdar A.J. 1999. Accelerated ageing characteristics of glass-fiber reinforced cement made with new cementitious matrices. Composites: Part A 30: 1073-1080.

Ramaswamy H. S.; Ahuja B. M.; Krishnamoorthy S. 1984. J. Mex. Inst. Cement Concrete 22-161

Rickard C. 2015. GRC developments in Australia, GRCA symposium, Dubai.

Richard P.; Cheyrezy M. 1995. Composition of reactive powder concretes. Cement and concrete research 25: 1501-1511.

Robinovic F. N.; Zenva, V. N.; Makeeva L. V. 2001. Stability of basalt fibers in a medium of hydrating cement. Glass Ceram. 58: 11-12.

Rothe, C.; Gao, L.S.; Plonka, R.; Mader, E. 2015. Nano surface structuring of alkali-resistant glass fibers for multifunctional effects. 1st International Conference Textile Reinforced Concrete. Leibniz Institute of Polymer Research Dresden, Germany

Rybin V. A.; Utkin A. V.; Baklanova N. I. 2013. Alkali-resistant coating for basalt fibers Prot. Met. Phys. Chem 49: 689-692.

Saida M.; Azimb Mahmoud A.; Ali M.; El-Ghazaly H.; Shaabanc I. 2020. Effect of elevated temperature on axially and eccentrically loaded columns containing Polyvinyl Alcohol (PVA) fibers. Engineering Structures 204: 110065.

Safiudin M.; Yakhlaf M.; Soudki K. A. 2018. Key mechanical properties and microstructure of carbon fiber reinforced self-consolidating concrete. Construction and building materials 164: 477-488.

Sheldon R. R. 1982. Composite Polymer Materials. London: Applied Science Publishers.

Sharma R., Khan R. A. 2018. Influence of copper slag and metakaolin on the durability of self compacting concrete, Journal of Cleaner Production 171: 1171-1186. 
Shi C.; Wu Z. 2015. A review on ultra high performance concrete. Construction and building materials 101: $741-751$.

Shon C. S., Lee D., Kim J. H., Chung C.W. 2018. Freezing and thawing resistance of cellular concrete containing binary and ternary cementitious mixtures. Construction and Building Materials 168: 73-81.

Siddique R. 2011. Utilization of silica fume in concrete: Review of hardened properties. Resources, Conservation and Recycling 55: 923-932.

Soni N., Shukla D. K. 2021. Analytical study on mechanical properties of concrete containing crushed recycled coarse aggregate as an alternative of natural sand, Construction and Building Materials 266: 120595.

Sprince A.; Korjakins A.; Pakrastinsh L. 2013. Time-dependent Behavior of High Performance Fiber-reinforced Concrete. Advanced Materials Research 05PP:75-80.

Sprince A.; Pakrastinsh L.; Vatin N. 2016. Crack formation in cement-based composites. IOP Conference Series: Materials Science and Engineering. Vol. 123, Issue 1.

Stein C. 2011. GRC for the Restoration of Historic Buildings. GRCA international conference, Istambul.

Sukontasukkul P. 2004. Toughness Valuation of Steel and Polypropylene Fiber Reinforced Concrete Beams under Bending. Tha mmasat Int. J. Sc. Tech. 9- 3: 35-41.

Tanyildizi H.; Yonar Y. 2016. Mechanical properties of geopolymer concrete containing polyvinyl alcohol fiber exposed to high temperature. Construction and Building Materials 126: $381-387$

Tanaka F.; Okabe T. 2018. Historical Review of Processing, Microstructures, and Mech nical Properties of PAN-Based Carbon Fibers. Comprehensive Composite Materials 1: 66-85.

Tasdemir M. A., Bayramov F. 2002. Mechanical behavior of cement based composite materials, ITU J/d Eng. 1 125-144.

Theodorakopoulos D.D. 1995. Shrinkage behaviour of GRC Thin Sheets. Cement and Concrete Composites 17: 229-238.

Toutanji H.; Xu B.; Gilbert J.; Lavin T. 2010. Properties of poly(vinyl alcohol) fiber reinforced high-performance organic aggregate cementitious material: Converting brittle to plastic. Construction and building materials 24: 1-10.

Urkhanova L. A.; Lkhasaranov S. A.; Rozina V. Y.; Buyantuev S. L.; Bardakhanov S. P. 2014. Increased corrosion resistance of basalt reinforced cement compositions with nanosilica. Nanotechn. Constr. 6: 15-29.

Wadell H. 1933. Sphericity and roundness of rock particles. J Geol 41:310.

Wu J. Y.; Xian G. J.; Hui L. I. 2011. Durability study of basalt fiber and its frp bars. Fiber Reinforced Plast./Compos. 32: 58-61 
Yakhlaf M.; Safiudin M.; Soudki K. A. 2013. Properties of freshly mixed carbon fiber reinforced self-consolidating concrete. Construction and building materials 46: 224-231.

Yakovlev G. I.; Politaeva A. I.; Galinovsky A. L.; Golubev V.A.; Saraykina K. A.; Zykova E. S. 2015. Nanostructuring as a method of adhesion properties increase of the "cement stone - basalt fiber reinforcement". Izv. KGASU-2 32: 281-288.

Yang E.H.; Li V.C. 2010. Strain-hardening fiber cement optimization and component tailoring by means of a micromechanical model. Construction Building Materials 24: 130139

Zhang X.F.; Xu S.L. 2008. Determination of fracture energy of three-point bending concrete beam using relationship between load and crack-mouth opening displacement, $J$. Hydraul. Eng. 39: 714-719.

Zheng J.; Hryciw R. D. 2015. Traditional soil particle sphericity, roundness and surface roughness by computational geometry. Géotechnique 65: 494-506.

Zhou Y.; Hou D.; Manzano H.; Orozco C. A.; Geng G.; Monteiro P. J.; Liu J. 2017. Interfacial connection mechanisms in calcium-silicate-hydrates/polymer nanocomposites: a molecular dynamics study. ACS Appl. Mater. Interfaces 9 (46): 41014-41025.

Zhu W.; Bartos, M.J. 1997. Assessment of interfacial microstructure and bond properties in aged GRC using a novel microindetation method. Cement and Concrete Research 27: $1701-1711$

Zinck, P.; Pays, M. F.; Rezakhanlou, R; Gerard, J.F. 1999. Mechanical characerisaion of glass fibers as an indirect analysis of the effect of surface treatment. Journal of Materials Science 34: 2121-2123.

Zingg T. 1935. Beitrag zur Schotteranalyse. Schweiz Miner Petrogr Mitt 15:39-140. 



\section{Autoriaus mokslinių publikacijų disertacijos tema sąrašas}

\section{Straipsniai recenzuojamuose mokslo žurnaluose}

Moceikis, R.; Kičaitè, A.; Skripkiūnas, G.; Korjakins, A. 2018. Ageing models and accel rated ageing tests of glass fiber reinforced concrete, Engineering structures and technologies. Vol 10(1): 10-17. eISSN 2029-8838.

Moceikis, R.; Kičaite, A.; Skripkiūnas, G.; Yakovlev, G. 2018. Mechanical characteristics and ductility of glass fiber reinforced concrete with modified matrix, Construction materials. Vol 12: 27-33. eISSN 2029-8838. ISSN 0585-430X.

Moceikis, R.; Kičaite, A.; Sahmenko, G.; Selskienė, A. 2020. Durability characterisation of glass fiber reinforced concrete by resistance to freezing and thawing, Journal of sustainable architecture and civil engineering. Vol 26(1): 10-17. ISSN 2029-9990.

\section{Straipsniai kituose leidiniuose}

Moceikis, R.; Kičaite, A.; Keturakis, E. 2017. Workability of glass reinforced concrete (GRC) with granite and silica sand aggregates, IOP Conference Series: Materials Science and Engineering. 3rd International conference Innovative Materials, Structures and Technologies. Vol 251: 1-8. ISSN 1757-8981.

Moceikis, R.; Karpova, E.; Kičaitè, A.; Skripkiūnas, G. 2019. Effect of aggregates on the technological and mechanical properties of glass and basalt fibers reinforced concrete, $3 r d$ World Multidisciplinary Civil Engineering, Architecture, Urban Planning Symposium (WMCAUS 2018). Vol 471: 1-8. ISSN 1757-8981. 
Moceikis, R.; Kičaite, A.; Skripkiūnas, G. 2019. Effect of aggregate particle shape and granuliometry on the workability and mechanical properties of glass reinforced concrete, The 13th international conference "Modern building materials, structures and techniques". 102-108. eISSN 20299915

Moceikis, R.; Kičaitė, A.; Sahmenko, G.; Korjakins, A. 2019. Properties of thin wall cement composites reinforced with AR glass, Carbon and PVA fibers, IOP Conference series: Materials science and engineering Vol 660(1): 1-7. ISSN 1757-8981 


\section{Summary in English}

\section{Introduction}

\section{Formulation of the problem}

After incorporating fibers with a high tensile strength and deformation modulus into the cementitious matrix, the brittle material (concrete) is transformed into a new type of composite resistant to the above-mentioned effects. In the scientific literature, the study of the mechanical properties of these composites is often limited to the bending strength, which does not specify the plastic properties inherent in these products. Therefore, to describe the mechanical strength of dispersive reinforced concrete composites, it would be expedient to use the flexural strain energy, which determines the ability of a material to plastically deform to failure (when the specimen reaches a certain deflection limit).

The workability of concrete mix influences the qualitative parameters of the surface of the formed product (structure, texture and number of pores) as well as the integrity of the cement matrix and the distribution of fibers in it. Therefore, it is necessary to investigate the effect of crushed rock aggregates on the workability and segregation of mixtures, to determine the dependences of these parameters on the particle shape of the aggregate. To improve technological parameters and performance characteristics of concrete composite with disperse reinforcement, active micro fillers can be used. The effect of these additives on the resistance of glass fiber-reinforced composites on the effects of freezing and thawing cycles and on the flexural strain energy has so far been very little studied. 


\section{Relevance of the thesis}

In the construction sector, the natural concrete facades have been rapidly gaining popularity recently. Although this trend is mainly related to the influence of architecture as an art form in the search for a new subtle materiality, it also touches on very important issues of the sustainability of building materials. Facades with a decorative concrete function have gained a great advantage in recent decades when the walls are designed from prefabricated three-layer or individual single-layer decorative wall elements. This method of construction allows significant savings in labor, automation of various technological processes that are easier to control and ensure significantly better product quality.

The use of dispersive reinforced concrete in the industrial production of three-layer wall elements is a promising innovation that would significantly facilitate constructions and reduce wall thickness. As a result, transportation costs would be reduced, loads on load-bearing walls, foundations, and the area of indoor premises would increase. It also shortens the product formation time, as it is no longer necessary to produce reinforcement frames. Since the wall elements are formed in a horizontal position in the factory, the use of such decorative concrete mixtures investigated in this work results in high-quality concrete surfaces.

Another wide range of applications for dispersive reinforced concrete is the use of casting or spraying suspended wall elements for ventilated facades. Compared to the popular Hitchek method of fibrous cement boards, it would be possible to go beyond flatshaped products and use special formwork to obtain complex shapes and various surface reliefs.

\section{The object of research}

The object of research is dispersive reinforced fine-grained decorative concrete with different aggregates and additives that modify the structure of the cement matrix.

\section{The aim of the thesis}

The aim of this work is to develop dispersive reinforced concrete for the production of prefabricated wall elements with different fibres, aggregates and mineral additives.

\section{The tasks of the thesis}

To achieve the goal of the work, the following tasks need to be solved:

1. To select raw materials and their proportions for the finishing concrete composite in the production of prefabricated wall elements, which would ensure the resistance of the product to brittle fracture and cracking.

2. To determine the effect of glass, basalt, carbon and polyvinyl alcohol fibers on the technological and mechanical properties of thin-walled finishing concrete when concrete mixtures are prepared by intensive mixing.

3. To determine the effect of particle shape of quartz sand, crushed granite and conventional gravel quarry sand aggregates on the workability and segregation of dispersive reinforced fine-grained concrete. 
4. To determine the effect of $\mathrm{SiO}_{2}$ micro fume and metakaolin mineral additives on the resistance of dispersive reinforced concrete to cyclic freezing and thawing, evaluating the defects of the concrete finishing surface - the amount of surface scaling and changes in flexural strain energy, when the product life expectancy is not less than 20 years.

5. To investigate the changes of fiber surface structure because of freezing and thawing cycles when the cement matrix is modified with $\mathrm{SiO}_{2}$ micro fume and metakaolin active mineral additives.

\section{Research methodology}

The effect of aggregates on the workability and segregation of concrete was investigated according to the methodology developed in this work. The effect of active mineral additives on the durability of concrete was determined by surface freezing and thawing tests, introducing a new criterion in the methodology of building materials testing, describing the work of the material up to full fracture - flexural strain energy. Other properties of dispersive reinforced concrete were determined according to the standards LST EN 1170-1, LST EN 1170-4, LST EN 196-1, LST EN 15191, LST EN 13198. A scanning electron microscope was used to study the changes in the structure of the matrix and fiber contact zone (SEM).

\section{Scientific novelty of the thesis}

The scientific novelty of the dissertation is described by the improvement of test methods for the assessment of durability of dispersive reinforced decorative concrete, as well as the modification of new cementitious mixtures using complex components and setting limit values for concrete and its components (components) operating in Baltic region climatic conditions. The following new results for materials engineering were obtained during the preparation of the dissertation:

1. The effect of crushed rock aggregates on the technological properties of concrete mixtures is explained and the influence of the aggregate particle shape on the workability and segregation of glass fiber reinforced fine-grained concrete mixture is determined.

2. The impact mechanism of $\mathrm{SiO}_{2}$ micro fume and metakaolin mineral additives under the action of flexural strain energy of fine-grained glass fiber reinforced concrete composite under cyclic freezing and thawing is explained.

3. Active mineral additives have different effects on the microstructure of finegrained concrete-cement matrix, on which the durability of concrete depends, described as the loss of mass of the finishing surface under cyclic freezing and thawing

\section{Practical value of the research findings}

A dispersive reinforced concrete composite has been developed, which can be used in the production of three-layer prefabricated wall elements by thinning the finishing concrete layer to $15 \mathrm{~mm}$. 
The effect of aggregate production waste - crushed granite and conventional gravel quarry sand aggregates on the technological and mechanical properties of concrete, when these aggregates are replaced by up to 50 quartz sand in the concrete mixture, was determined.

A methodology for assessing the durability of glass fiber reinforced concrete finishing surface according to the area of the detached surface was developed and the effect of metakaolin and $\mathrm{SiO}_{2}$ micro fume additives on surface destruction was investigated.

\section{Defended statements}

1. Segregation of the glass fiber reinforced fine-grained concrete mixture decreases by increasing the amount of round filler particles that ensure even distribution of the cement matrix and fiber.

2. Active mineral additives of metakaolin and $\mathrm{SiO}_{2}$ micro fume increase the flexural strain energy of glass fiber reinforced fine-grained concrete composite after the action of freezing and thawing cycles.

3. Active mineral additives have a different effect on the microstructure of a finegrained concrete-cement matrix, on which the durability of the concrete depends, described as the loss of mass of the finishing surface under cyclic freezing and thawing.

\section{Approval of the research findings}

7 scientific articles have been published on the topic of the dissertation: three - in the peer-reviewed scientific journals (Moceikis et al. 2018a; Moceikis et al. 2018b; Moceikis et al. 2020), two in the publications of the Clarivate Analytics Web of Science database in Conference Proceedings (Moceikis et al. 2017; Moceikis et al. 2018c) and two in the other conference proceedings (Moceikis et al. 2019a; Moceikis et al. 2019b;).

Results of the research were published in seven scientific conferences in Lithuania and abroad:

- International 19 ${ }^{\text {th }}$ Young Scientists Conference „Juniorstav“, 2017, Brno, Czech Republic;

- $20^{\text {th }}$ Lithuanian Young Scientists Conference „Science-Lithuania's Future“, 2017, Vilnius;

- $\quad 3^{\text {rd }}$ International Conference "Innovative Materials, Structures and Technologies" 2017, Riga;

- $\quad 4^{\text {th }}$ International Conference "World Multidisciplinary Civil Engineering - Architecture - Urban Planning Symposium” 2018, Prague;

- $13^{\text {th }}$ International Conference ,Modern Building Materials Structure and Techniques", 2019, Vilnius;

- $\quad 4^{\text {th }}$ International Conference ,,Innovative Materials, Structures and Technologies“, 2019, Riga;

- $28^{\text {th }}$ International Conference on XXVIII Scientific and Technological Conference of the Latvian Concrete Association (LCA), 2019, Riga. 


\section{Structure of the thesis}

The dissertation consists of an introduction, three chapters, general conclusions, lists of used literature sources and the author's publications, summary in English. The volume of the dissertation is 121 pages, excluding appendices, 11 numbered formulas, 74 figures and 15 tables are used in the text. 128 literature sources were used in writing the dissertation.

\section{Research analysis of technological and performance characteristics of decorative concrete with disperse reinforcement}

The effect of fiber reinforcement on the mechanical properties of cement matrix is characterized by an increase in the impact strength of the matrix as well as flexural strain energy and resistance to tensile stresses. Fiber reinforced fine graded decorative concrete is used to form precast concrete products. These can be wall elements of new buildings, facade details of historic buildings, landscaping products, interior details.

Conventional Portland cement, fine sand $\left(D_{\max }=2 \mathrm{~mm}\right)$, superplasticizer, glass fibers and water are used for the basic glass fiber reinforced concrete composition. Commonly used filler to binder ratio is $1: 1$, glass fiber content by weight $2-5 \%$ of dry materials, water/cement ratio is between $0.3-0.4$. The density of hardened concrete varies between 1800 and $2200 \mathrm{~kg} / \mathrm{m}^{3}$, depending on the composition of the concrete.

The shear mixing method is used for these fine-grained mixtures when the concrete mixer has high-speed (up to $1500 \mathrm{rpm}$ ) rotating shaft with a spring-shaped nozzle.

The properties of hardened concrete depend on such factors as the method of production, type and amount of fibers, hardening conditions, structure of the cement matrix. In the case of flowable concrete, workability of the fresh mix is also a very important parameter. Research has shown that fine grained glass fiber-reinforced concrete has a flexural strength of 10-15 MPa, depending on the fiber content and cement matrix composition (Peter 2015).

Studies on the workability of concrete have shown that at a dosage of $12 \mathrm{~kg} / \mathrm{m}^{3}$ and $40 \mathrm{~kg} / \mathrm{m}^{3}$ of basalt fiber to normal concrete mixture cannot be mixed because the mixture becomes stiff and fiber balling occurs (Branston et al., 2016).

Yakhlaf (2013) found that carbon fibers severely deteriorated the workability of selfcompacting normal concrete when the fiber was dosed $0.25 \%$ from dry weight of the materials. Arisoy (2008) and Toutanji (2010) found that PVA fibers increased the plasticity (deflection at maximum load) of normal concrete by 50 to 150 times, and flexural strength by $50-250 \%$.

Due to intense chemical corrosion in alkaline media, conventional fiberglass cannot be used in systems with a Portland cement binder. The chemical composition of alkaliresistant glass, developed in the 1960s, was improved by the inclusion of zirconium oxide: $\mathrm{SiO}_{2} 71 \%, \mathrm{ZrO}_{2} 16 \%, \mathrm{Na}_{2} \mathrm{O} 12 \%$ and $\mathrm{Li}_{2} \mathrm{O} 1 \%$.

According to the Australian Association of Reinforced Concrete Manufacturers, known values for the 28-day flexural strength of spray-produced concrete range from 21 to $35 \mathrm{MPa}$. When the products are used under natural climatic conditions, the bending strength gradually decreases until it reaches a constant value. According to the abovementioned Australian recommendations, the maximum long-term strength of $17 \mathrm{MPa}$ is 
achieved with a new type of cementitious matrices, for example by modifying the metakaolin additive. The long-term strength of typical sprayed glass fiber reinforced concrete used in production is $13.5 \mathrm{MPa}$ in Australian climates and $15 \mathrm{MPa}$ in Great Britain.

For a long time, the main cause of the decrease in strength has been thought to be chemical reactions in the contact zone of the glass fiber and cement matrix. However, empirical studies by scientists have refuted this assumption, as long term tests by Litherland and sampling of existing buildings showed no signs of significant chemical reactions in the fiber-matrix contact zone or a reduction in the cross-sectional area (Bentur et al., 1985; Cohen et al., 1985; Diamond et al., 1985; Jaras et al., 1975). Based on the results of these studies, scientist Purnell (2001) proposed a theoretical model of corrosion of glass fiber reinforced concrete based on the occurrence of nano-cracks on the fiber surface. This phenomenon in the glass scientific literature is called static fatigue and is described as the gradual cracking of $\mathrm{SiO}_{2}$ bonds at the tips of the cracks under static loading.

Enfedaque (2009) compared the flexural strength data obtained by two different methods (freezing/thawing and wetting/drying). Typical matrix specimens were found to lose the same amount of initial strength after 50 freeze/thaw cycles as after 200 wetting/drying cycles. It can be assumed that the long-term strength of glass fiber reinforced cement composite can be determined using the freezing/thawing test method instead of soaking in hot water or drying wetting according to EN 1170-8, which usually takes significantly longer (up to 8 times) to obtain the same data.

\section{Materials used for the composite and research methods}

Portland cement CEM I 52.5R with the same characteristics, manufactured in accordance with the requirements of the standard LST EN 197-1: 2011, was used in the tests for all concrete mix compositions. Portland cement particle size distribution was determined using a laser particle analyzer CILAS 1090 Liquid.

Fine aggregates with the largest particles $\mathrm{d}_{\max }=2 \mathrm{~mm}$ were used in the studies. Several aggregates of different granulometry and origin were selected: natural quartz quarry $\left(\mathrm{d}_{\max }=1.25 \mathrm{~mm}\right)$, crushed granite $\left(\mathrm{d}_{\max }=2 \mathrm{~mm}\right)$, natural gravel quarry sand $\left(\mathrm{d}_{\max }=\right.$ $2 \mathrm{~mm})$. Granulometric compositions were determined according to the standard LST EN12620: 2003 A1: 2008 using a standard set of sieves for concrete aggregates.

$\mathrm{SiO}_{2}$ micro fume and metakaolin were used as micro fillers for modifying the structure of a cementitious matrix that are often used in engineering practice to improve various properties of finishing concrete. Particle size distribution of these additives were determined by a laser analyzer CILAS 1090 Liquid.

A high-efficiency and widely used polycarboxylate ether-based superplasticizer was used to plasticize the cement matrix.

Several different fibers have been selected for cement matrix reinforcement - glass, basalt, carbon and polyvinyl alcohol (PVA).

Binder/filler ratio used was 1:1 for the base composition, the amount of superplasticizer was $1.1 \%$ by weight of the binder, the amount of glass fiber was $2.9 \%$ by weight of the filler-binder matrix and the water/binder ratio $\mathrm{V} / \mathrm{C}=0.36$.

To evaluate the effect of different fillers on the consistency and mechanical properties of the basic SPAB matrix, part of the quartz was replaced with alternative fillers - 
crushed granite and natural sand, changing their amount up to 50, at intervals of $10 \%$ $(0 \%, 10 \%, 20 \%, 30 \%, 40 \%, 50 \%)$.

Effect of different fibers on the properties of the GRC base matrix was determined according to the second group of test mixtures. The selected control glass fiber content was $2.9 \%$ from the matrix weight. The content of basalt and carbon fibers was reduced to $1.45 \%$ and $0.7 \%$, respectively, due to their significant effect on the consistency of the mixture. The amount of PVA fiber is converted to specific gravity and corresponds to the amount of glass fiber in units of volume at $1.5 \%$ by weight of the matrix.

For the workability testing of concrete mixtures, the cylinder slump method, suitable for fine-grained cementitious composites with fibers up to $20 \mathrm{~mm}$ in length, was chosen. Inner diameter of the cylinder is $57 \mathrm{~mm}$, and height of $55 \mathrm{~mm}$. Microscopic pictures of aggregates were used to determine particle shape influence on the mix workability.

Flexural strength was determined in accordance with LST EN 1170-4 when tested according to the four-point test scheme. Flexural strain energy was calculated based on RILEM recommendations. Compressive strength of concrete was determined in accordance with the LST EN 12390-3.

Density of the samples was determined according to LST EN 12390-7: 2009.

The frost resistance of concrete was determined by the surface freezing method. The samples were kept in a climate chamber for up to 112 freezing and thawing cycles with a duration of 24 hours per cycle. The tested surface of each sample $(150 \times 262 \mathrm{~mm})$ was coated with a $5 \mathrm{~mm}$ thick solution of $3 \% \mathrm{NaCl}$. Every 7 days, the samples are removed from the freezer for a maximum of 30 minutes, the $\mathrm{NaCl}$ solution is poured off, the surface of the sample is scrubbed with a metal brush and the surface fragments are collected by washing with a water jet, dried, weighed and the surface weight loss is calculated in $\mathrm{g} / \mathrm{m}^{2}$.

\section{Research of technological and performance characteristics of decorative concrete with disperse reinforcement modified by mineral additives}

For thin-walled decorative concrete elements, it is important that the fiber reinforcing the matrix structure is oriented as horizontally as possible in the direction of the external tensile forces. Also, the concrete mix of cast products must be technological and flowable and fill the formwork.

In tests with different fibers, it has been observed that the workability of the mixture deteriorates significantly with the use of basalt and carbon fibers (Fig. S.3.1). Changes in workability are related to the fact that during mixing, the fibers break down into single filaments, which are widely distributed in the matrix volume and increase the area of the fiber-matrix contact zone, which has also been found in other researchers (Branston et al., 2016; Yakhlaf et al., 2013; Safiudin et al., 2018). After evaluating the research carried out by the researchers, it was chosen to perform experiments with $2.9 \%, 1.45 \%$ basalt fiber contents and $0.72 \%, 0.18 \%$ carbon fiber contents. The amount of PVA fiber chosen $(1.5 \%)$ corresponds to the fiber content by volume, as the densities of these materials differ almost twice. 


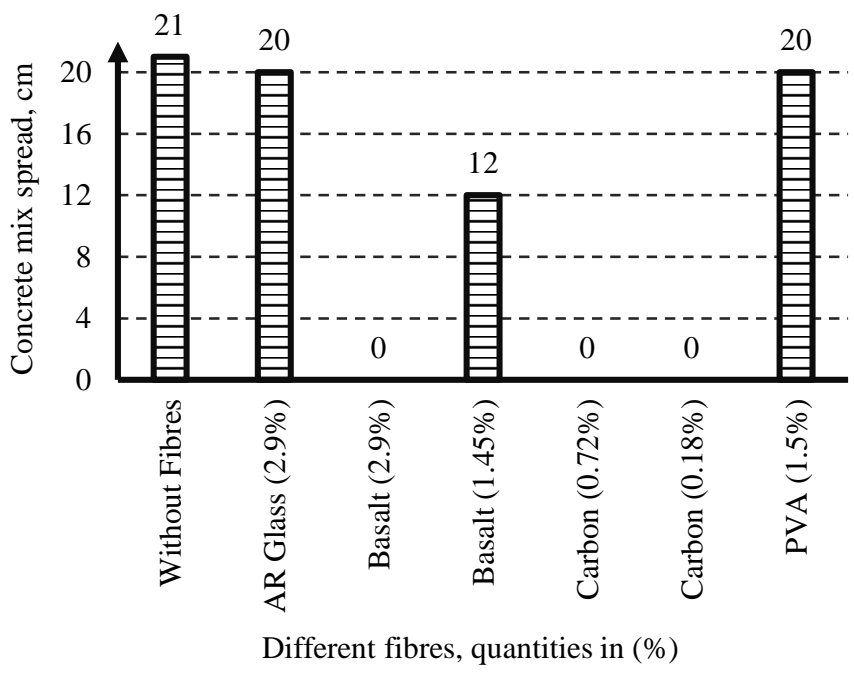

Fig. S3.1. Effect of fiber type on the slump of concrete mix (test cylinder $57 \times 55 \mathrm{~mm}$ )

Summarizing the mechanical properties of fine-grain concrete with different fibers, it can be stated that glass fibers increased the flexural strain energy of cementitious matrix by 38 times and polyvinyl alcohol fibers by 114 times, thus giving the brittle material plastic properties when the fibers were dosed at $2.9 \%$ and $1.5 \%$ from the dry weight of the cement matrix. Although the highest compressive strength $93 \mathrm{MPa}$ was obtained with carbon fiber, this characteristic is not so important for the elements subjected to bending deformation forces.

As flowable concrete mixtures are studied in this work, the ability of the mixture to spread quickly and evenly and to fill the formwork of the formed product is especially important. In the production of thin-walled products, it is difficult to apply concrete compaction means. Therefore, an important requirement for concrete mixtures is spreading, shrinkage and segregation resistance of the mixture.

The use of alternative fillers for quartz sand significantly deteriorated the workability of the concrete mix, in some cases resulting in high fiber-matrix segregation. Therefore, it was proposed to introduce a new parameter for the workability of the mixture, the segregation index $W$ :

$$
W=\frac{D_{1}-D_{2}}{h},
$$

where, $D_{1}$ is the maximum diameter of the dispersed mixture, calculated as the average of the two perpendicular measurements, $\mathrm{cm} ; D_{2}$ is the inside diameter of the scattered mixture, calculated as the average of the two perpendicular measurements, $\mathrm{cm}$; h- slump of the concrete mixture, $\mathrm{cm}$. 


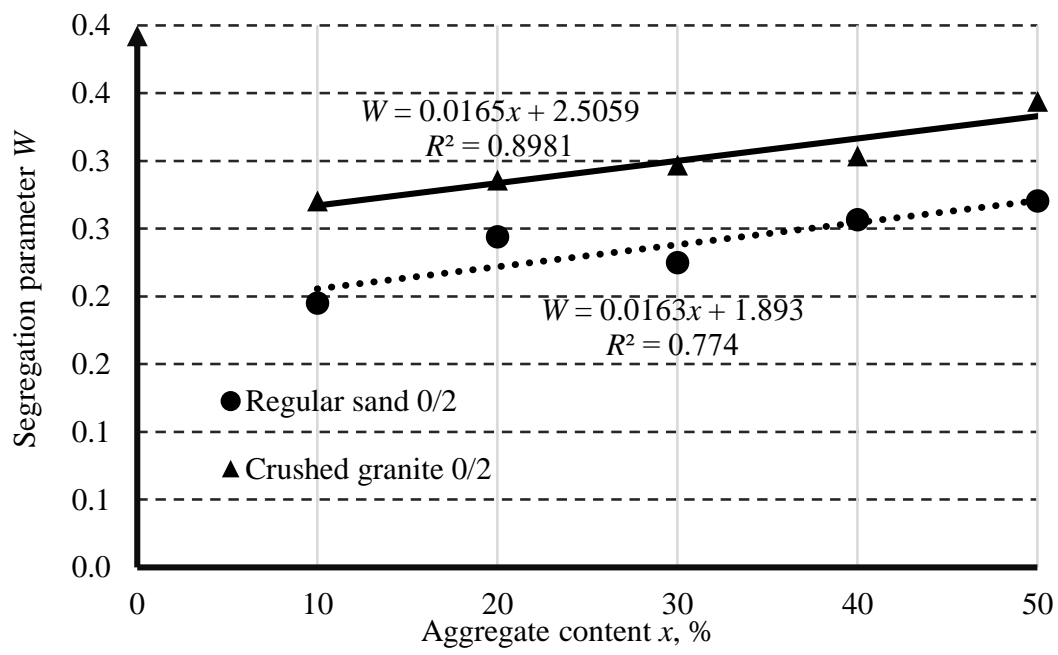

Fig. S3.2. Segregation parameters for compositions with different aggregates quantities

Influence of aggregates on the workability of the concrete mix can be explained by the shape of the aggregate particles. Quartz particles have a spherical shape with smooth surfaces, which results in less friction between the cement matrix, the filler and the fiber. Crushed granite particles have a plate-like shape with sharp edges, which particularly increases the internal friction of the matrix, the fiber gets stuck between the larger particles, and the smaller ones flow through the gaps together with the cement mortar (Figure S3.3). The particles of conventional sand aggregate have irregular spatial polygonal shapes, so the consistency parameters of the mixtures are close to the compositions with granite aggregate.

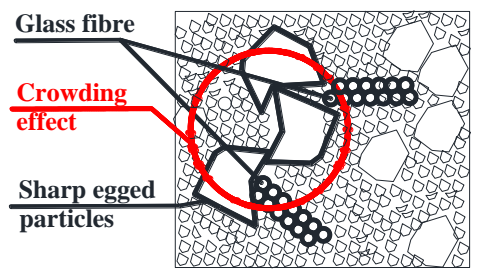

Fig. S3.3. Crowding effect of fibers when sharp edged particles are introduced

Using up to $7.5 \% \mathrm{SiO}_{2}$ micro fume the spread of the concrete decreased from $19 \mathrm{~cm}$ to $13 \mathrm{~cm}(31 \%)$ and with $7.5 \%$ metakaolin to $15 \mathrm{~cm}(21 \%)$. This difference in effect on workability can be explained by the fact that the surface area of silica fume particles is significantly larger than that of metakaolin.

Density measurements of concrete mix with different aggregates showed that the density of basic fiber-reinforced concrete mix with quartz aggregate was $2190 \mathrm{~kg} / \mathrm{m}^{3}$, and 
the granite aggregate increased the density of fresh concrete by up to $2221 \mathrm{~kg} / \mathrm{m}^{3}$ while sand up to $2242 \mathrm{~kg} / \mathrm{m}^{3}$.

The results of the research showed that the maximum flexural strength of the basic glass fiber reinforced composite with quartz sand is $13.3 \mathrm{MPa}$, and the compressive strength is $82.9 \mathrm{MPa}$, when the samples are $40 \mathrm{~mm}$ thick prisms. Changing the specimens to $15 \mathrm{~mm}$ thick plates resulted in a reduction of flexural strength to $10.2 \mathrm{MPa}$, and when specimens in 100x100 cubes, the compressive strength decreased to $74.2 \mathrm{MPa}$.

Studies with different aggregates have shown that replacing $10 \%, 20 \%, 30 \%$, $40 \%, 50 \%$ quartz with granite or regular sand reduces the flexural strength of the composite and ranges between 11.34-12.68 $\mathrm{MPa}$ when using granite and between 12.2213.27 MPa when using regular sand.

No significant effect on flexural strength was observed when dosing micro-fillers up to $7.5 \%$ from the cement mass. The strength of the samples with silica fume ranged from 9.1 to $10.6 \mathrm{MPa}$, where the lowest value was obtained with $5 \%$ additive. Metakaolin had an even smaller effect, the results ranged from 10.3 to $10.7 \mathrm{MPa}$.

The highest value of compressive strength was obtained with $7.5 \% \mathrm{SiO}_{2}$ micro fume (4 MPa). Lowest with $2.5 \%$ metakaolin $(-7 \mathrm{MPa})$. It has been observed that increasing the amount of additives results in an increase in strength, which could be explained by a deterioration in consistency and an overall decrease in the ratio of water to cement with mineral additives in the system.

It was found that the amount of entrained air in the GRC mix without micro-fillers is $2.5 \%$ and that silica fume and metakaolin affect this parameter differently. Mixtures with metakaolin were characterized by a decrease in the amount of entrained air to $2 \%$, and an increase up to $4.7 \%$ for compositions with silica fume.

Freeze/thaw resistance tests were performed with 7 different concrete compositions (S1, MS1, MS2, MS3, MK1, MK2, MK3) and lasted for 112 days, tested according to the surface cooling method given in Annex B of LST EN13198, where the duration of one full $/-20^{\circ} \mathrm{C}$ cycle -24 hours. Every 7 freezing/thawing cycles, the surfaces of the samples were cleaned, the material separated from the surfaces was dried and weighed, and the surfaces were refilled with $3 \% \mathrm{NaCl}$ solution. The total loss of mass of the scaled material from the surface of the samples after cycles 56 and 112 is given in Figures S3.4 and S3.5.

The addition of silica fume had a negligible effect on surface mass loss (Figure S3.4), which could be explained by the large amount of air introduced in the concrete mix. The highest recorded value is $67 \mathrm{~g} / \mathrm{m}^{2}$, with $2.5 \%$ silica fume. As the amount of silica fume increased, the amount of entrained air increased and the weight loss decreased to $45 \mathrm{~g} / \mathrm{m}^{2}$ and $0 \mathrm{~g} / \mathrm{m}^{2}$, respectively. 


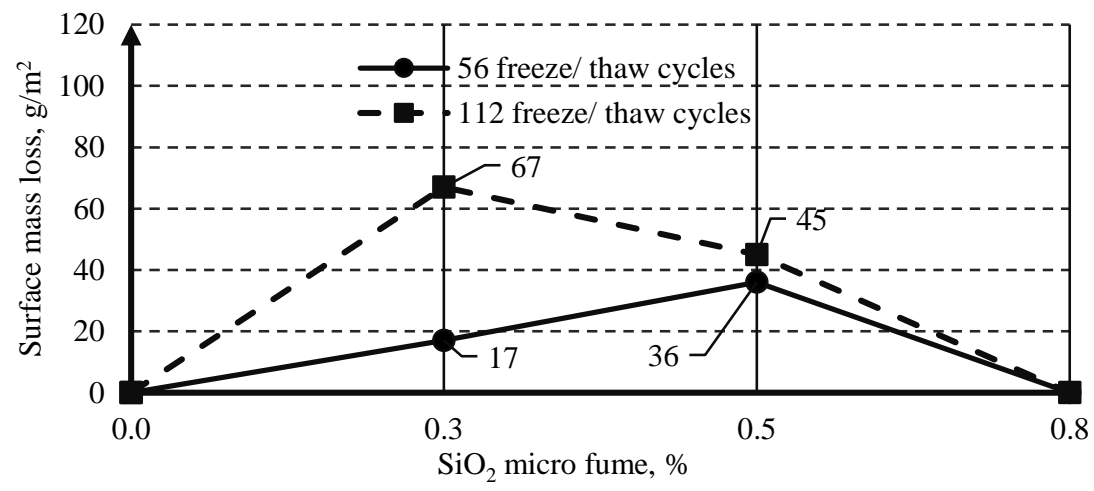

Fig. S3.4. Impact of silica fume on scaling at freezing and thawing

The addition of metakaolin had a greater negative effect on concrete surface damage (Figure S3.5). When $2.5 \%$ and $5 \%$ were used for this additive, the weight loss after 112 cycles was similar to that with the silica fume and did not exceed $50 \mathrm{~g} / \mathrm{m}^{2}$. However, the $7.5 \%$ metakaolin addition significantly increased the weight loss from the concrete surface to $115 \mathrm{~g} / \mathrm{m}^{2}$ after 56 cycles and to $465 \mathrm{~g} / \mathrm{m}^{2}$ after 112 cycles, respectively. This can be explained by the high density of the matrix due to the increased amount of fine particles and the decreased amount of entrained air in the concrete mix $(2.5 \%)$.

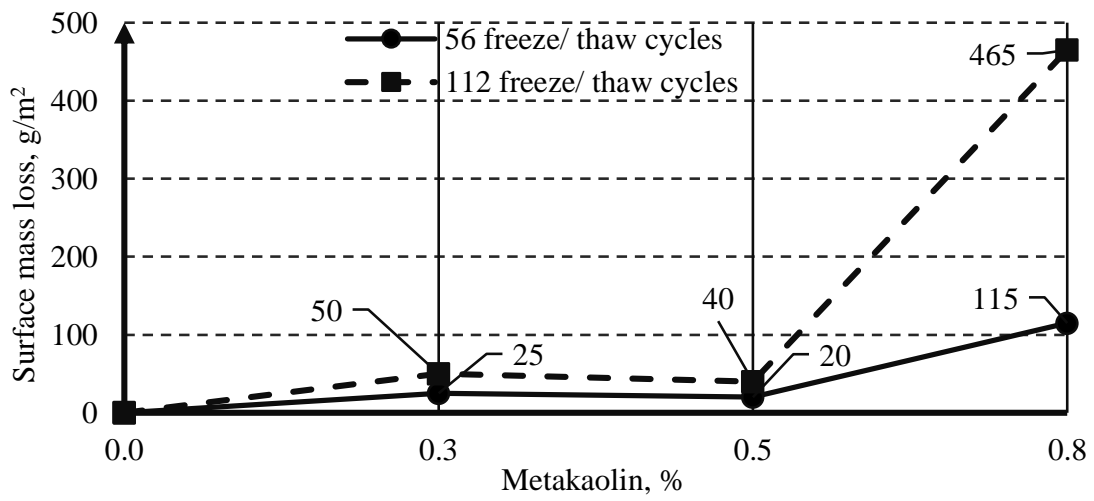

Fig. S3.5 Impact of metakaolin on scaling at freezig and thawing

In this study, the maximum surface weight loss of concrete specimens was 3 times lower than required by the standard when the number of freezing/thawing cycles exceeded the requirements by 4 times. Nevertheless, the damage to the concrete surfaces was very pronounced visually and occupied $465 \mathrm{~g} / \mathrm{m}^{2}$ which is up to $50 \%$ of the sample surface area and $67 \mathrm{~g} / \mathrm{m}^{2}(10 \%)$, respectively (Figure S3.6). The highest resistance of the concrete finishing surface to the effect of freezing/thawing was obtained with the base composition without micro additives $-0 \mathrm{~g} / \mathrm{m}^{2}$ after 112 cycles. 


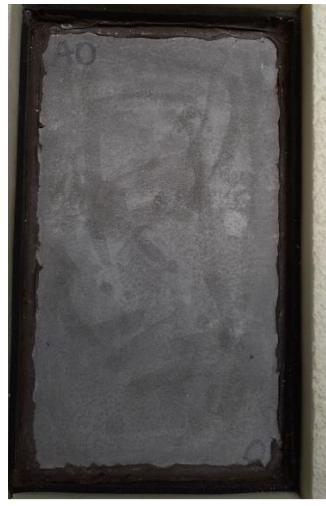

a)

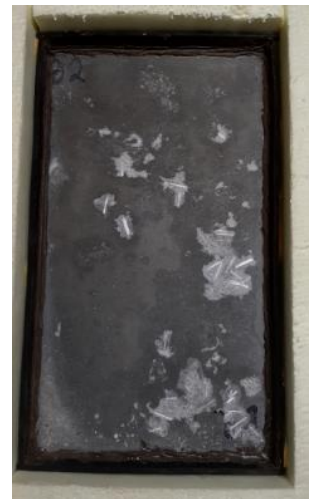

b)

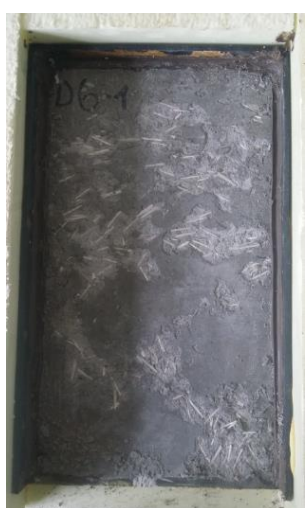

c)

Fig. S3.6. Photos of specimens after 112 freeze/thaw cycles: a) S1, with no additives;

b) MS2 with $5 \%$ silica fume; c) MK3 with 7,5\% metakaolin

It was found that the addition of silica fume increased the flexural strain energy up to $92 \%$ before freezing and $85 \%$ after 112 freeze/thaw cycles and metakaolin $-90 \%$ before and $108 \%$ after 112 freezing/thawing cycles (Figures S3.7, S3.8). This means that the plasticity of the composite was increased, and more energy is needed to break it down, the material has become more resistant to dynamic forces, which is very important for thinwalled facade structures.

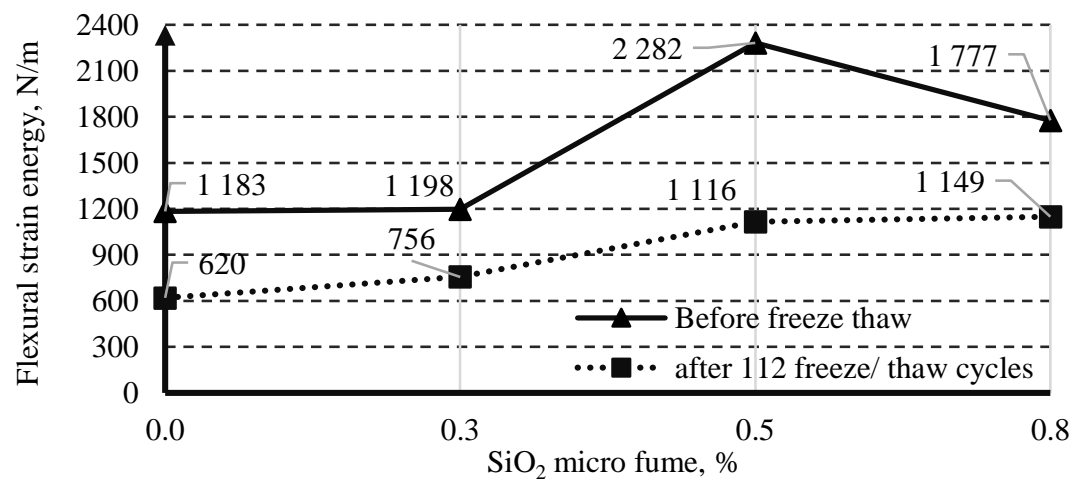

Fig. S3.7. Impact of silica fume on flexural strain energy 


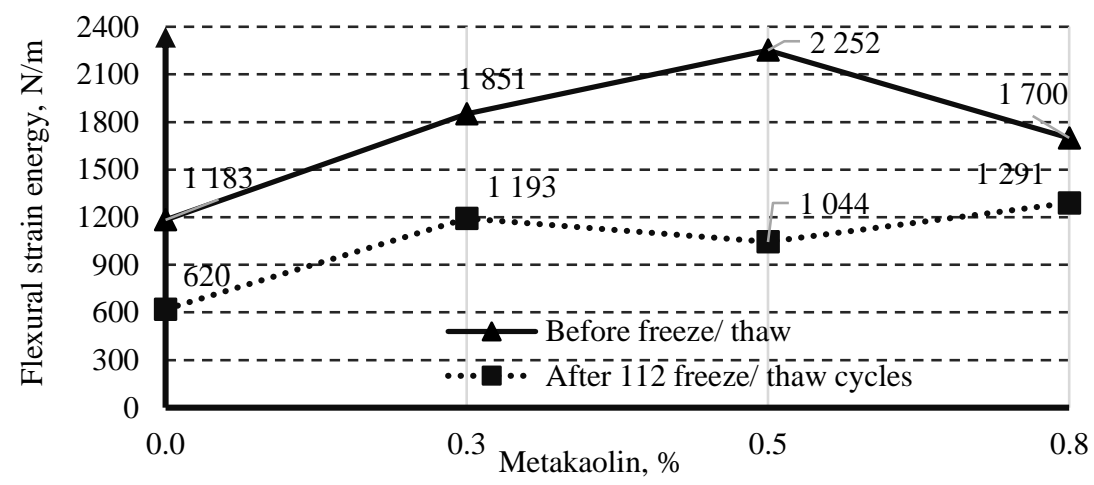

Fig. S3.8. Impact of metakaolin on flexural stain energy

In the samples with micro fillers the surface of the glass fiber filaments after freezing tests did not have the surface defects that were noticed in specimens without active micro fillers. Also, no cracks were observed in the fiber-matrix contact zone in specimens with metakaolin and silica fume.

Based on the results of these experiments and the research carried out by scientists, it can be stated that the degree of deterioration of the mechanical properties of glass fiber reinforced concrete with increasing service life of the composite depends primarily on the alkalinity of the matrix pore solution. Due to the ongoing hydration in the contact zone, the surface of fibers is increasingly covered with hydration products, the morphology and chemical composition of which depend on the binder composition.

A thin layer of C-S-H phases, which results in good bonding properties, predominates in cases where the content of cement clinker in the binder is low and additives that cause pozzolanic reactions (low alkalinity of the pore solution) are used. In cementitious matrices in which only Portland cement is used as a binder, the coarse, brittle phases of Portlandite (high alkalinity of the pore solution) predominate. As the alkalinity of the cement matrix increases, so does the amount of portlandite phases that form certain brittle coatings on the glass fiber surface. Interference of $\mathrm{Ca}(\mathrm{OH})_{2}$ crystals between fiber agglomerates can also be observed. Growing Portlandite crystals act as wedges to distort the protective outer shell of glass filaments.

In cementitious matrices using active mineral additives, the $\mathrm{pH}$ values of the pore solution decrease due to pozzolanic reactions. The conditions for the formation of portlandite in this case are limited, which results in a favorable microstructure of the fibermatrix contact zone. The formation of new thin films on the surface of the outer fibers ensures better adhesion of the fiber to the matrix. Studies by scientists on the addition of metakaolin to glass fiber reinforced concrete during wetting and drying cycles have also shown that this additive reduces the brittleness of the composite due to ongoing aging processes, as in the freeze-thaw tests performed in this work. 


\section{General conclusions}

1. Workability and segregation of fine-grained glass fiber-reinforced concrete mixture depend on the particle shape of the aggregate, which can be described by an elongation index, which is expressed as the ratio of the longer side of the particle to the shortest. As the elongation rate increases, consistency deteriorates and segregation increases. As the elongation index of the aggregate increases by $3 \%$, the spread of the mixture decreases by $10 \%$ when conventional sand is used instead of quartz sand. When an irregularly shaped aggregate (crushed granite) is used, the elongation index of the particles increases by $33 \%$ compared to quartz sand, and the spread of the mixture decreases accordingly by $50 \%$. Increasing the amount of regular sand from $10 \%$ to $50 \%$ increases the segregation index from 1.9 to 2.6, and using crushed granite from 2.6 to 3.5 , respectively.

2. For glass fiber-reinforced fine-grained concrete aggregates may be used in which spherical particles predominate and elongation index does not exceed 1.4, ensuring even distribution of cement matrix and fibers. Also, for this type of mixtures the segregation index is important, which needs to be assessed during technological operations and can be calculated according to the methodology proposed in this work.

3. When preparing concrete mixtures by intensive mixing, the agglomerates of carbon and basalt fibers decompose into individual fibers and the mixture becomes stiff and non-technological. In this respect, a glass fiber is more suitable, the fibers of which, even during intensive mixing, remain adhered to the agglomerates and remain in a straight shape, thus ensuring the required spreading of the mixture and sufficient reinforcement of the cement matrix.

4. Disperse reinforcement can increase concrete mechanical characteristics. Glass fiber was found to increase the flexural strain energy of the cement matrix from $28 \mathrm{~N} / \mathrm{m}$ to $1039 \mathrm{~N} / \mathrm{m}$ (38 times), and polyvinyl alcohol fiber from $28 \mathrm{~N} / \mathrm{m}$ to $3102 \mathrm{~N} / \mathrm{m}$ (114 times), thus giving the brittle material plasticity properties when the fibers are dosed at $2.9 \%$ and $1.5 \%$ by weight of dry matter, respectively.

5. After 112 surface freezing and thawing cycles in $3 \% \mathrm{NaCl}$ solution, it has been found that active silica fume and metakaolin additives can negatively affect the appearance of glass fiber reinforced decorative concrete products, as they cause surface scaling and cracking of concrete when dosed up to $7.5 \%$ from the cement mass. When evaluating the appearance of decorative products, it is proposed to apply different quality classes (A, B, C) by limiting the surface area of detached concrete from $50 \mathrm{~cm}^{2} / \mathrm{m}^{2}$ to $500 \mathrm{~cm}^{2} / \mathrm{m}^{2}$.

6. After 112 freezing and thawing cycles in $3 \% \mathrm{NaCl}$ solution, the addition of silica fume increases the flexural strain energy of glass fiber reinforced concrete from $620 \mathrm{~N} / \mathrm{m}$ to $1149 \mathrm{~N} / \mathrm{m}(85 \%)$ and metakaolin from $620 \mathrm{~N} / \mathrm{m}$ to $1149 \mathrm{~N} / \mathrm{m}$ (108\%). In this way, due to the higher plastic deformations and the residual strength, these additives help the composites in question to remain 
resistant to mechanical degradation under aggressive climatic conditions during natural weathering.

7. During the aging processes due to the freezing and thawing cycles, the postexposure glass fiber reinforced composite enters a brittle state, possibly due to the resulting cracks between the fiber and the matrix contact zone, as well as defects in the fiber surface. These aging processes can be slowed down using active mineral additives (silica fume and metakaolin).

8. The concrete composite was developed for production of prefabricated wall elements with quartz sand filler and fiberglass, with a bending strength of 10.1 MPa, flexural strain energy of $1149 \mathrm{~N} / \mathrm{m}$ and which can be used for facade structures operating at least 20 years of aggressive climatic conditions in the Baltic region, characterized by the effects of freezing and thawing cycles. 



\section{Priedai $^{3}$}

A priedas. Portlandcemenčio CEM I 52,5R fizikinès ir mechaninès savybès

B priedas. Užpildụ pagrindinès fizikinès ir cheminès charakteristikos

C priedas. Aktyvių mineralinių priedụ fizikinès charakteristikos

D priedas. Superplastiklio charakteristikos

E priedas. Betono mišinių sudètys

F priedas. Autoriaus sąžiningumo deklaracija

G priedas. Bendraautoriu sutikimai teikti publikacijoje skelbtą medžiagą mokslo daktaro disertacijoje

H priedas. Autoriaus mokslinių publikaciju disertacijos tema kopijos

${ }^{3}$ Priedai pateikiami pridètoje kompaktinejje plokštelèje. 
Rimvydas MOCEIKIS

DISPERSIŠKAI ARMUOTO APDAILINIO BETONO

TECHNOLOGINIŲ IR EKSPLOATACINIŲ SAVYBIŲ TYRIMAI

Daktaro disertacija

Technologijos mokslai,

Medžiagų inžinerija (T 008)

INVESTIGATION OF TECHNOLOGICAL AND

PERFORMANCE CHARACTERISTICS OF DECORATIVE

CONCRETE WITH DISPERSE REINFORCEMENT

Doctoral Dissertation

Technological Sciences,

Materials Engineering (T 008)

202106 07. 12,0 sp. I. Tiražas 20 egz.

Leidinio el. versija https://doi.org/10.20334/2021-032-M

Vilniaus Gedimino technikos universitetas,

Saulètekio al. 11, 10223 Vilnius

Spausdino Bl UAB „Baltijos kopija“

Kareivių g. 13b, 09109 Vilnius 